\title{
قيام الصبي بالواجب الكفائي في العبادات دراسة فقهية مقارنة
}

\author{
إعداد الدكتور \\ خالد بن معيض آل كاسي \\ الأستاذ المساعد بقسم الفقه
}

- كلية الثريعة وأصول الدين - جامعة الملك خالد بأبها 



\section{قيام الصبي بالواجب الكفائي في العباداته}

\section{قيام الصبي بالواجب الكفائي في العبادات \\ دراسة فقهية مقارنة}

خالد بن معيص آل كاسي

قسم الفقه، كلية الثريعة وأصول الدين، جامعة الملك خالد، أبها، الملكة

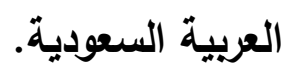

\section{البريد الإكتروني: kassi1016@hotmail.com}

\section{ملخص البحث}

إن الناظر في أحكام الثريعة الغراء يرى أن من الأحكام ما هو مطلوب من جميع الأمة من كل ذات وعين، وهي فروض الأعيان المطلوبة من كل المكلفين

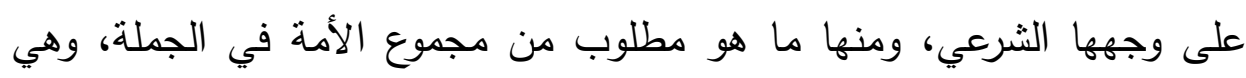
فروض الكفاية، التي إذا قام بها من يكفي سقطت عن الباقين، ومقصود الثارع منها حصول الفعل، وتحقيق مقصده ومبتغاه .

ولقد كان للثشارع الحكيم عظيم الاهتمام بجميع المسلمين صغيرِهم وكبيرِهم، وأولى عناية خاصة للصبيان منهم؛ إذ هم يمثلون جزءًا كبيراً في المجتمع الإسلامي؛ حتى يصبر شاباً قائداً نافعاً، يعود على أمته ودينه ونفسه بالفلاح في إنه

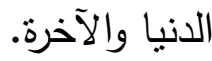

ولا غرو فهم المؤهلون بعد ذللك للتكليف الثرعي، وكم راعى الثارع الحكيم المصالح الدينية والدنيوية في تصرفات الصبي المميز النافعة، فاعتبرها وأجازها وصححها خاصة في العبادات؛ لذا قصدت ببحثي هذا أن ألقي الضوء بالبحث

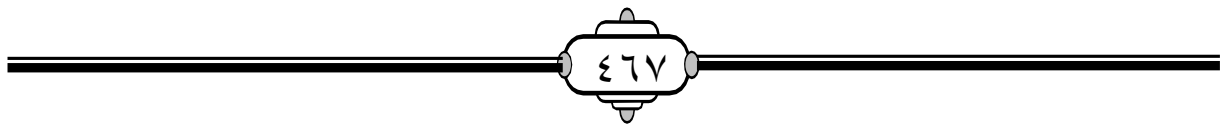




\section{قيام الصبي بالواجب الكفائي في العباداته}

والدراسة وجمع مبثوث المسائل في موضوع: قيام الصبي بالواجب الكفائي في العبادات، ومدى كفاية ذلك وسقوطه عن البالغين.

وقد تحدثت في بحثي هذا عن قيام الصبي بالواجب الكفائي في العبادات،

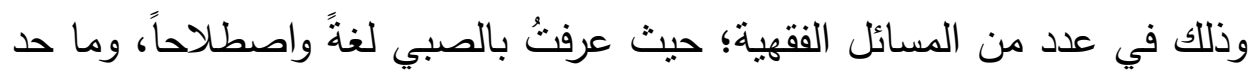

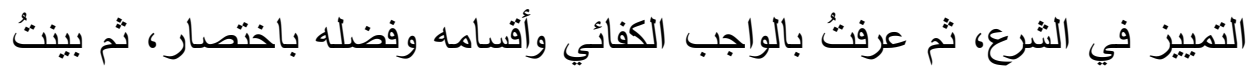

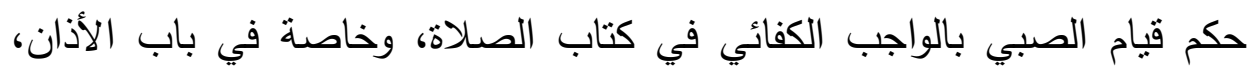

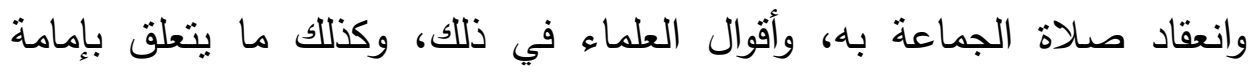
الصبي، وانعقاد صلاة العيدين به، ثُ تحدثت عن قيام الصبي بالواجب الكفائي في

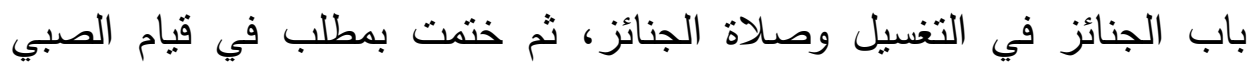
بالواجب الكفائي في رد السلام، وكلام الفقهاء في ذللك، ثم أنهيت البحث بخاتمة

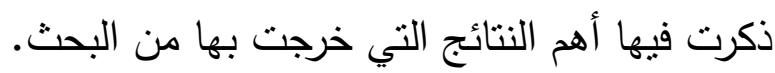
الكلمات المفتاحية: قيام، الصبي، الواجب، الكفائي، العبادات. 
the boy's fulfillment of the obligatory duty in worship

khaled bin maeid aal Kasy

Jurisprudence Department, College of Sharia and Fundamentals of Religion

King Khalid University, Abha, Saudi Arabia.

Email: kassi1016@hotmail.com

\section{Abstract}

The one who looks into the rulings of the noble Sharia sees that among the rulings therein is what is required of all the ummah from every self and consciousness, which are the duties of the notables that are required of all those charged with its legitimate view, and among them is what is required of the whole ummah in the sentence, which are the obligations of sufficiency, which if he rises With it, whoever suffices it has fallen from the rest, and the intention of the street is the occurrence of the act, and the fulfillment of its purpose and goal.

Not surprisingly, they understood those qualified after that for legal assignment, and how much the wise street took into account the religious and worldly interests in the behavior of the discerning and beneficial boy, so he considered them,

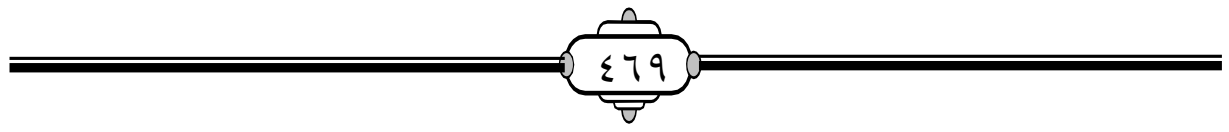


permitted them and corrected them, especially in acts of worship. Therefore, I intend with this research to shed light on research, study and collecting anthology of issues on the topic: the boy's fulfillment of the obligatory duty in worship, and the extent of this adequacy and his fall from adults.

In my research, I talked about the boy performing the obligatory obligation in acts of worship, and that is in a number of jurisprudential issues, where I knew the boy in language and idiomatically, and what is the limit of discernment in the Sharia, then I knew about the obligatory duty and its divisions and preferences in short, then I explained the ruling on the boy performing the obligatory duty in the book of prayer, Especially in the chapter on the call to prayer and the holding of the congregational prayer with it, and the sayings of the scholars on that, as well as what is related to the leadership of the boy, and the holding of the Eid prayers in it, then talked about the boy performing the obligatory duty in the section of the funeral prayer in the ablution and funeral prayer, then concluded with a requirement that the boy perform the obligatory duty In the response to peace, and the words of the jurists regarding that, then I finished the research with aconclusion in which I

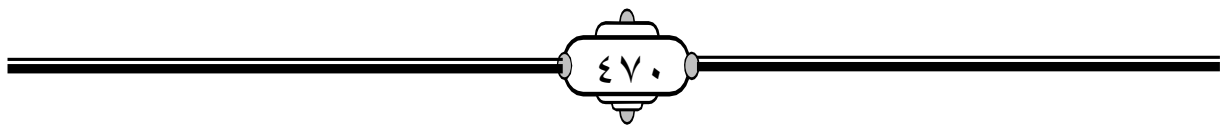


قيام الصبي بالواجب الكفائي في العباداتَ"

mentioned the most important results that I came out of the research.

Keywords: the boy's, fulfillment, the obligatory, duty, worship

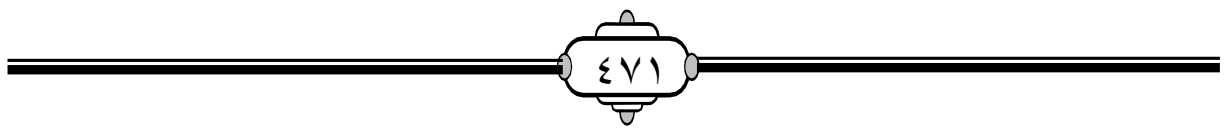




\section{بسم الله الرحمن الرحيم}

الحمد لله رب العالمين، القائل في محكم التنْزيل:

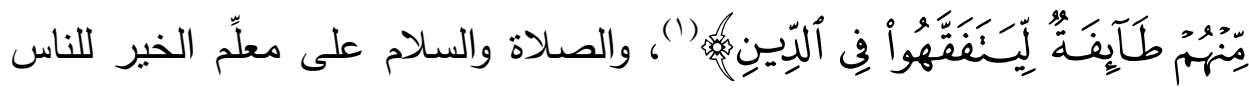
أجمعين، القائل، (من يرد الله به خيراً يفقهه في الدين)(؟)، وعلى آله الطيبين الطاهرين، وصحبه الأخيار الغر الميامين، والتابعين لهم بإحسان إلى يوم الدين، وبعد ...

فإن الناظر في أحكام الشربعة الغراء يرى أن من الأحكام ما هو مطلوب من جميع الأمة من كل ذات وعين، وهي فروض الأعيان المطلوبة من كل المكلفين على وجها الثرعي، ومنها ما هو مطلوب من مجموع الأمة في الجملة، وهي فروض الكفاية، التي إذا قام بها من يكفي سقطت عن الباقين، ومقصود الثارع منها حصول الفعل، وتحقيق مقصده ومبتغاه. ولقد كان للشارع الحكيم عظيم

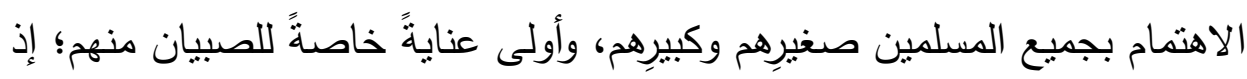

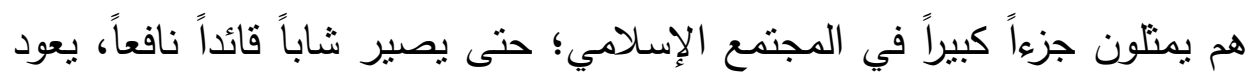
على أمته ودينه ونفسه بالفلاح في الدنيا والآخرة. ولا غرو فهم المؤهلون بعد ذلك للتكليف الثرعي، وكم راعى الثارع الحكيم المصالح الدينية والدنيوية في تصرفات الصبي المميز النافعة، فاعتبرها وأجازها وصححها خاصة في العبادات؛ لذا قصدت ببحثي هذا أن ألقي الضوء بالبحث والدراسة وجمع مبثوث المسائل في موضوع: قيام الصبي بالواجب الكفائي في العبادات، ومدى كفاية ذلك وسقوطه عن البالغين .

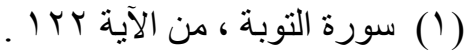

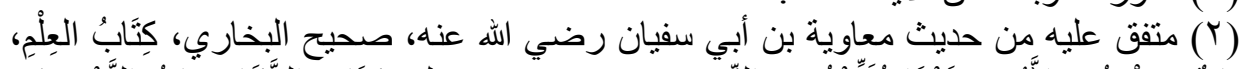

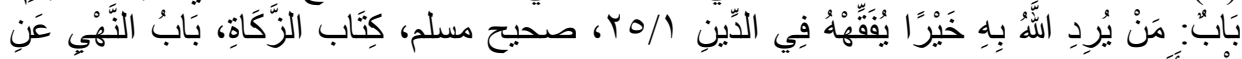

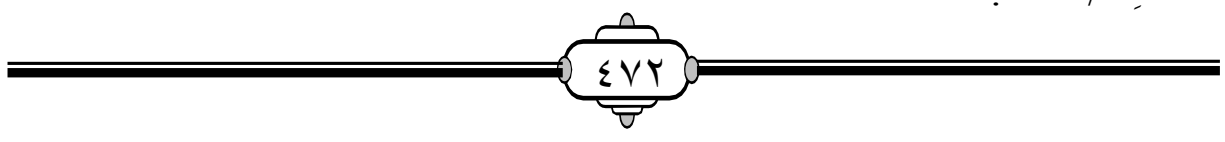




\section{قيام الصبي بالواجب الكفائي في العباداته}

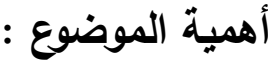

1- عناية الثارع الحكيم بالأحكام الفقهية المتعلقة بالصبي، وخاصة فيما

يتعلق بالواجب الكفائي في العبادات التي تخص الصبي •

r- اهتمام الثارع الحكيم بالمصالح الدينية والدنيوية في تصرفات الصبي الهبي

المميز النافعة، لذللك اعتبرها وأجازها وصحدها خاصة في العبادات .

r- تعلق الموضوع بجانب مهم من جوانب الثريعة الإسلامية، وهو

الواجب الكفائي في حق الصبي، وهو مما يلامس حياة الصبي المسلم بشكل

· مباشر

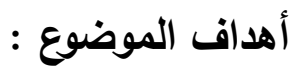

1- إبراز عناية الفقه الإسلامي بأحكام الصبي في جميع مراحل حياته الدينية

والدنيوية .

r- محاولة جمع المسائل الفقهية المتعلقة بالواجب الكفائي في العبادات التي

تخص الصبي، وتجليتها للباحثين والمطلعين •

r- إثراء المكتبة الإسلامية بالمسائل المتعلقة بالواجب الكفائي للصبي في الفقه

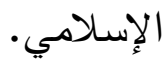

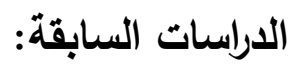

لم أجد دراسة سابقة حول هذا الموضوع على حد بحثي مما كُتب حول أحكام

الصبي.

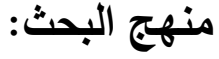

1- اعتمدتُ في بحثي هذا على المنهج الوصفي لما جاءت به الثريعة

الإسلامية، واستقراء النصوص الثرعية، وتحليل أقوال الفقهاء، والمقارنة فيما بينها، وترجيح الراجح منها بلا هوى أو تعصب لرأي بعينه، وإنما وفق ميزان الترجيح المعروف في الأبحاث العلمية.

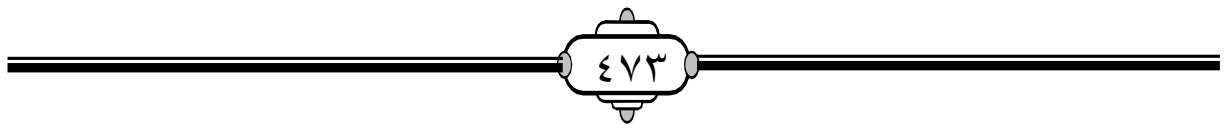




\section{قـيام الصبي بالواجب الكفائي في العباداته}

r- عزو الآيات القرآنية إلى سُوَرِها مع بيان رقم الآية .

r- الإحالة إلى مصدر الحديث أو الأثر، وذلك بذان الذكر اسم الكتاب والباب الإبه

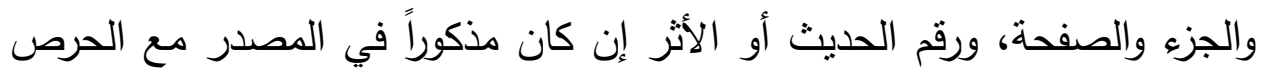

على ذكر الراوي من الصحابة.

ع- إن كان الحديث في الصحيحين أو أحدِهما اكتقيت بتخريج الحديث

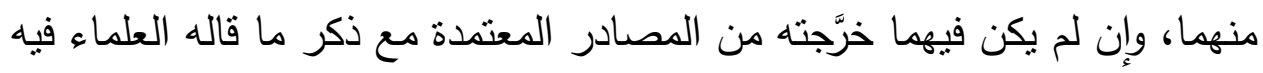
تصحيحاً وتضعيفاً.

ه- ترجمتُ للأعلام الواردة في البحث، غير المشهور من الصحابة والأئمة

צ- ترجمتُ للمصادر والمراجع بصورة شاملة في نهاية البحث، مكتفيًا بذكر

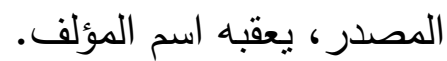

خطة البحث: وقد قسمت خطة البحث إلى مقدمة، وأربعة مباحث، وخاتمة،

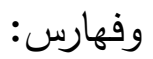

أما المقدمة: فتشمل أهمية الموضوع وأهدافه، ثم خطة البحث كما يلي: المبحث الأول: التعريف بالصبي وبيان مدى مخاطبته شرعاً، وفيه أريعة

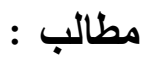

المطلب الأول: التعريف بالصبي والألفاظ التي تطلق عليه .

المطلب الثاني: حد التمييز في الصبي • لأني

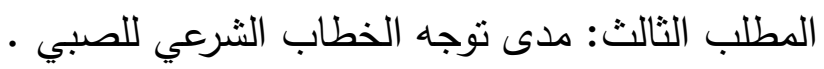

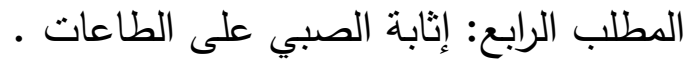

المبحث الثاني: تعريف الواجب الكفائي وبيان فضله ، وفيه مطلبان :

المطلب الأول: تعريف الواجب الكفائي ، وذكر أقسامه بإيجاز •

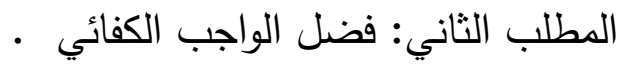

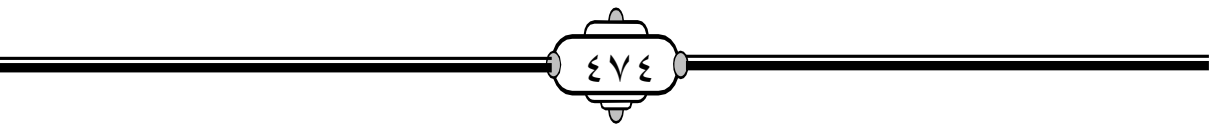




\section{قيام الصبي بالواجب الكفائي في العباداته}

المبحث الثالث: قيام الصبي بالواجب الكفائي في الأذان والصلاة، وفيه

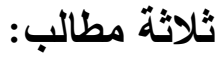

المطلب الأول: حكم أذان الصبي وإقامته ، وفيه فرعان :

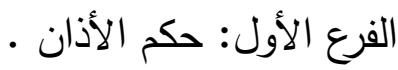

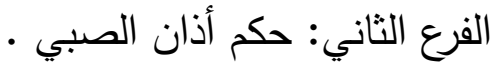

المطلب الثاني: حكم انعقاد صلاة الجماعة بالصبي ، وفيه ثلاثة فروع:

$$
\text { الفرع الأول: حكم صلاة الجماعة . }
$$

الفرع الثاني: هل تتعقد صلاة الجماعة بالصبي ويسقط بها فرض الفرل

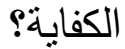

الفرع الثالث: حكم إمامة الصبي في صلاة الجماعة .

المطلب الثالث: حكم صلاة العيدين وانعقادها بالصبي ، وفيه فرعان :

الفرع الأول: حكم صلاة العيدين •

الفرع الثاني: حكم انعقاد صلاة العيدين بالعدد الذي فيه صبي مميز

وإمامته فيها .

المبحث الرابع: قيام الصبي بالواجب الكفائي في الجنائز ، وفيه ثلاثة

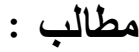

المطلب الأول: حكم تغسيل الصبي المميز غيره ـ

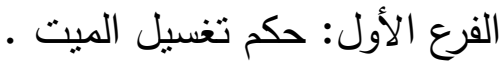

الفرع الثاني: حكم تغسيل الصبي للميت .

المطلب الثاني: حكم قيام الصبي بصلاة الجنازة دون البالغين، وفيه فرعان :

الفرع الأول: حكم صلاة الجنازة .

الفرع الثاني: هل يسقط فرض الكفاية بصلاة الصبي على الجنازة ؟.

المطلب الثالث: قيام الصبي المميز بتكفين الميت وحمله ودفنه .

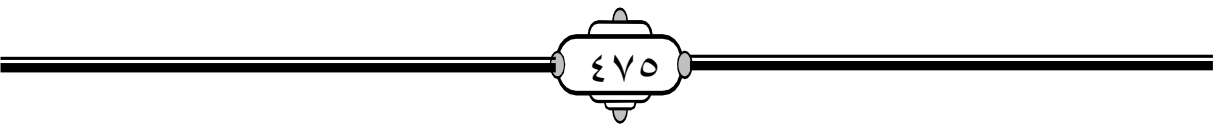


قيام الصبي بالواجب الكفائي في العبادات口

مطلب في: رد الصبي المميز وحده السلامَ دون البالغين، وهل يسقط به

$$
\text { فرض الكفاية عنه؟؟. }
$$

والله الموفق والمعين

0

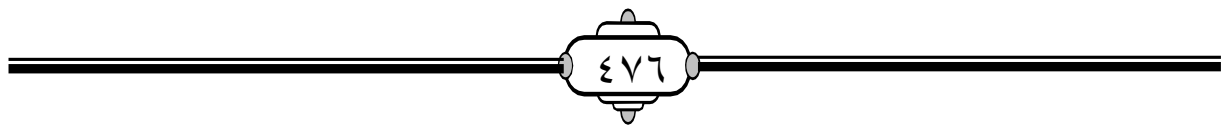




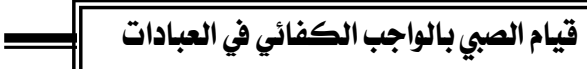

\section{المبحث الأول}

التعريف بالصبي وبيان مدى مخاطبته شرعاً

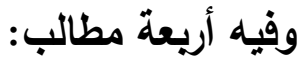

المطلب الأول: التعريف بالصبي والألفاظ التي تطلق عليه

أولاً: تعريف الصبي لغةً: الصبي لفظ يطلق على الاول الذكر والأنثى، ويقال

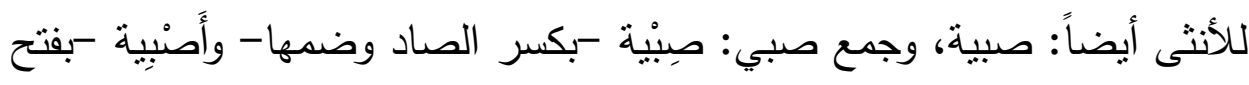
الهمزة- وصِيْوة -بكسر الصاد وفتحها- وصُوبيان -بكسر الصاد وضمها-

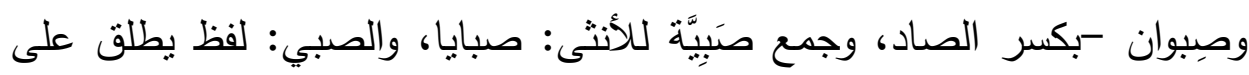
الإنسان من وقت ولادنه إلى فطامه (1).

ثانياً: الألفاظ التي تطلق على من لم يبلغ: هناك ألى ألفاظ كثيرة تطلق على التى

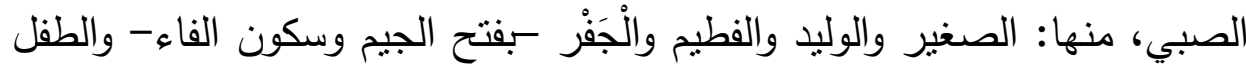

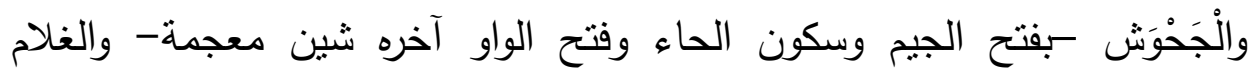

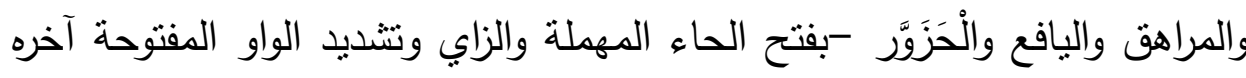
راء- وهو الغلام الذي شب وقوي وخدم وكاد يبلغ، وقيل: هو حَزَوَّر إذا بلغ عشر التر

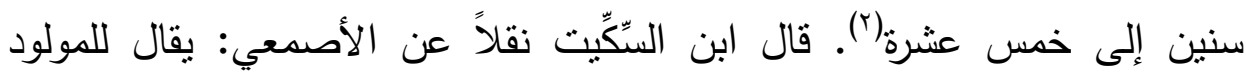

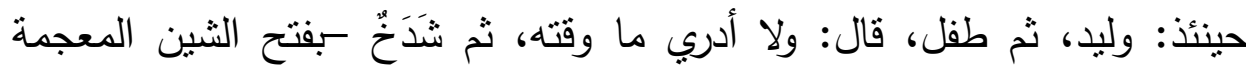

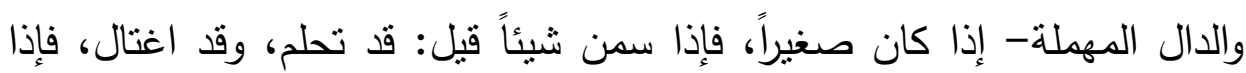

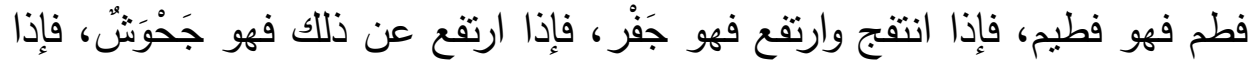
خدم وقوي فهو حَرََّر، فإذا ارتفع ولم يبلغ الحلم فهو يفعة ويافع، يقال: غلام يافع،

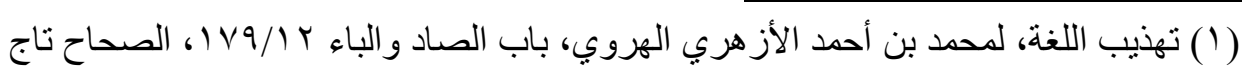

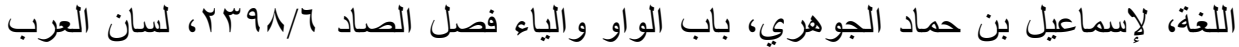

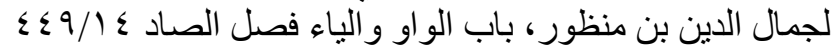

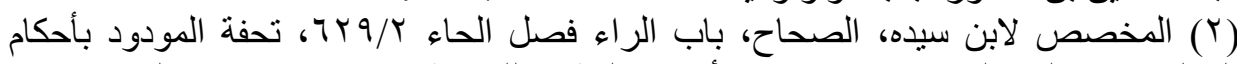

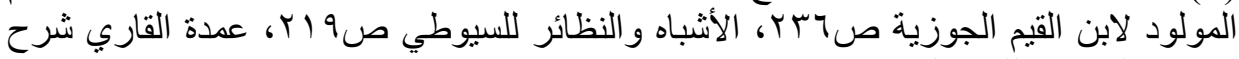

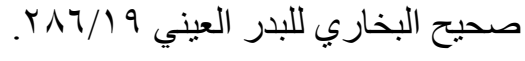


وغلام يفعة، وغلمان يفعة، الواحد والجميع فيه سواء، وقد يقال: غلمان أيفاع، وقد أيفع الغلام يوفع إيفاعاً (') ثالثاً: تعريف الصبي شرعاً: يستعمل الفقهاء لفظ الصبي في كل صغير لم يبلغ الحلم(؟). وهذا استعمال أوسع وأشمل للفظ الصبي من استعمال أهل اللغة.

$$
\text { المطلب الثاني: حد التمييز في الصبي }
$$

هل التمييز في الصبي يكون بالسن، ببلوغه سبع سنين، أم أنه لا تشترط فيه سن معينة بل بوجود وصف التمبيز؟.

\section{اختلف الفقهاء في ذلك على أقوال :}

القول الأول: ذهب الحنفية في المعتمد، والمالكية، والثافعية في المشهور، والحنابلة في قول كصوبه صاحبا المبدع والإنصاف- إلى أن الصبي المميز هو الذي يفهم الخطاب، ويرد الجواب، ولا ينضبط بسن، بل يختلف باختلاف الأفهام؛ لأن اشتقاق اللفظ يدل عليه، أي أن كلمة 》امميّز هاسم فاعل مشتق من التَّبيز، وإذا كان مشتقاً من ذلك، فإذا وُجدَ هذا المعنى في طفل ثَبَتَّ له الوصف، والمراد بفهم الخطاب ورد الجواب: أنه إذا تكلم بثيء من مقاصد العقلاء فهمه وأحسن

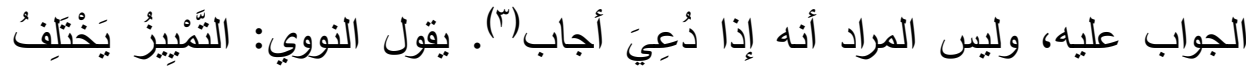

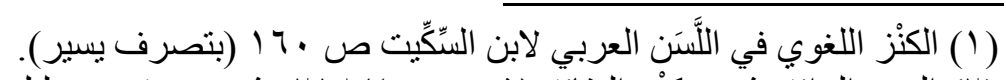

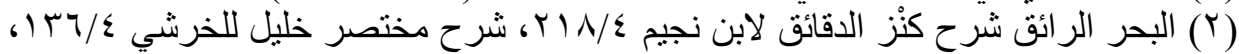

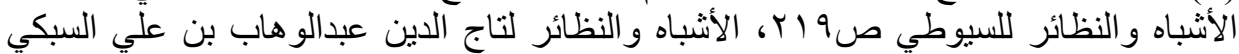

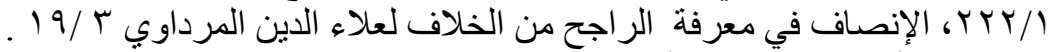

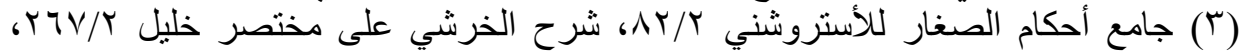

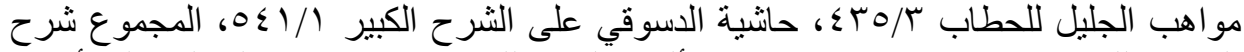

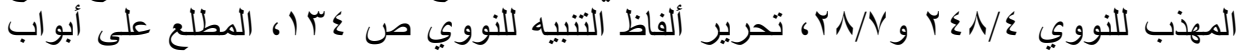

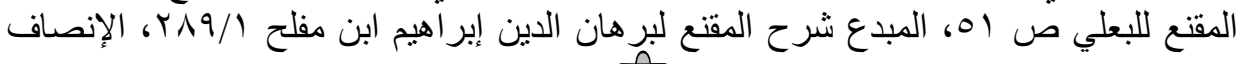




\section{قيام الصبي بالواجب الكفائي في العباداتص}

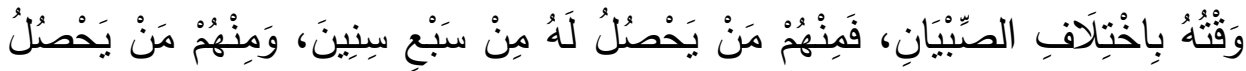

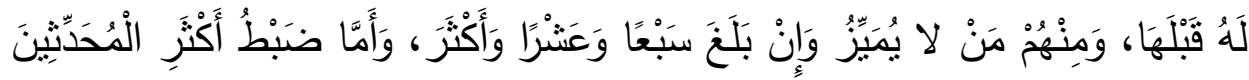

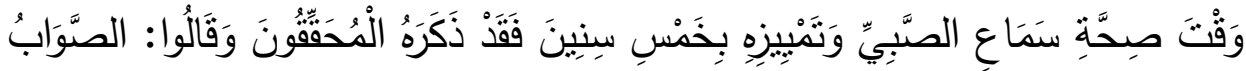

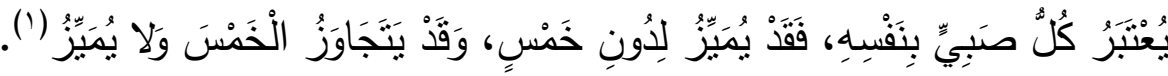

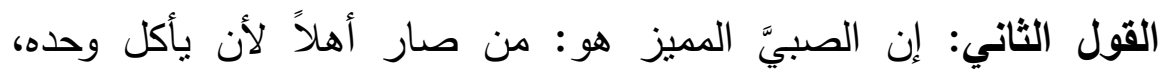
ويشرب وحده ويستجي كنلك. وإليه بعض الحنفية وبعض الثنافعية(؟).

القول الثالث: الصبي المميز هو الذي يعرف يمينه من شماله، أي يعرف ما يضره وما ينفعه، وإليه ذهب بعض الحنفية وبعض الثنافعية(") . واستخلوا على ذلك بما روي أن النبي أسئل سئل: متى يؤمر الصبي بالصلاة؟

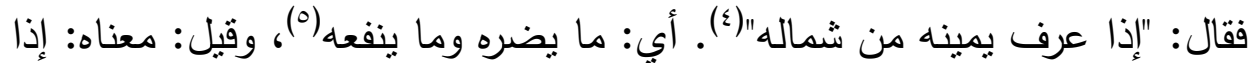

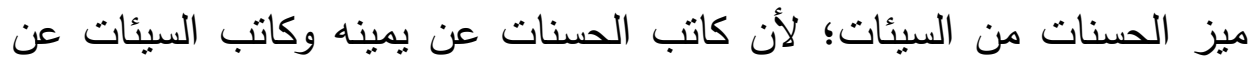

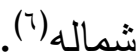

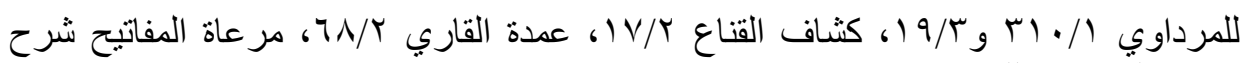

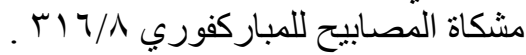

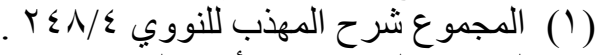

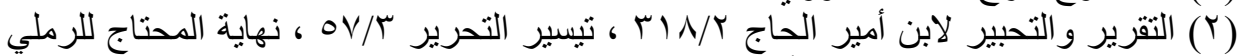

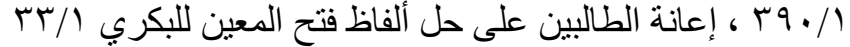

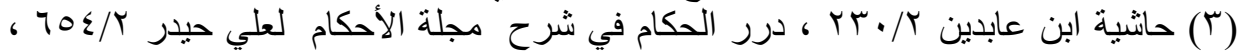

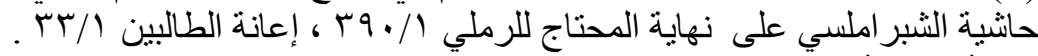

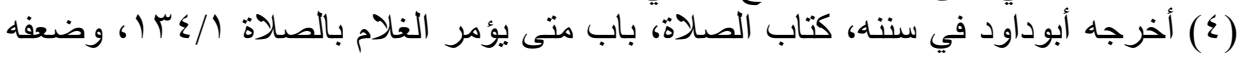

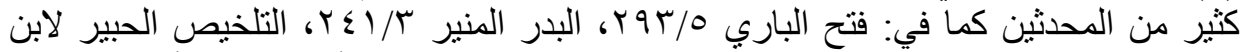

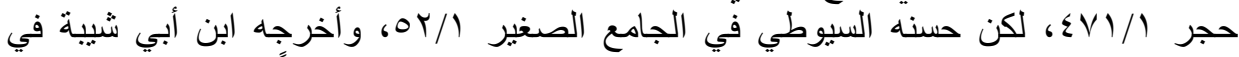

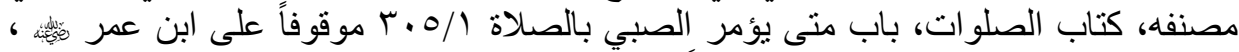

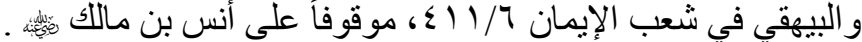

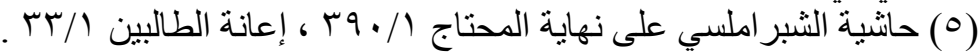

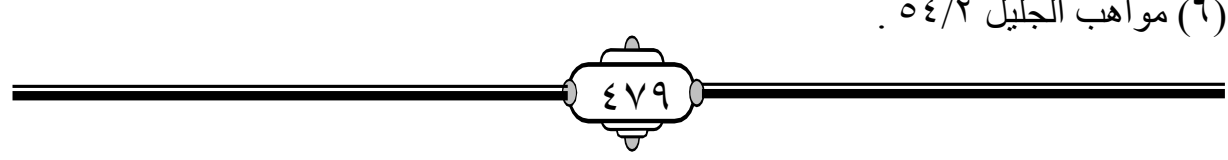


القول الرابع: إن الصبي المميز هو الذي بلغ سبع سنين، وإليه ذهب بعض

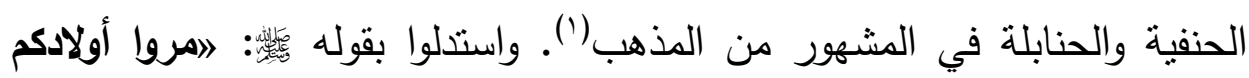

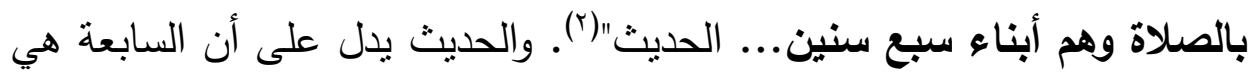
سن التمييز وفهم الخطاب؛ لأن وليه مأمور أن يأمره بالعبادة وهي الصلاة إذا بلغها، وأما قبل هذه السن فهو صبي غير مميز (r) . وقالوا: فإذا كان الصبي بحيث يفهم الخطاب ويرد الجواب يكون صالحاً لتحمل الحديث -يعني روايةً - لكن في الغالب لا يكون على هذه الحينية قبل بلوغ السبع، ولذا أمر الأولياء بأمرهم بالصلاة حين بلوغهم هذا السن، وأما تعقل محمود

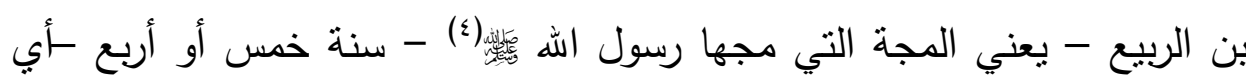
من عمره- وحفظ الإمام الثافعي الموطأ وهو ابن خمس، وحفظ الإمام سهل بن عبد الله التستري بعض الأوراد وهو ابن سنتين فمن جملة الكرامات لا يينى عليه

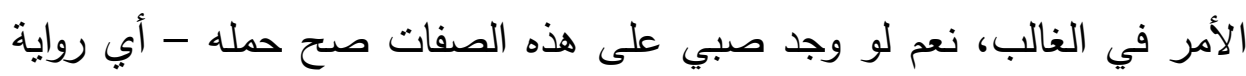
الحديث- البتة ولذا ما شرطنا سناً لكنه قلما يوجد فئ.

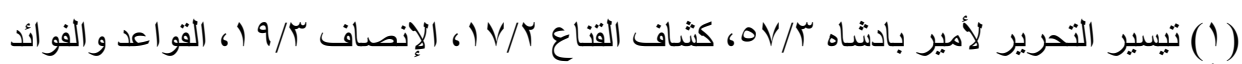

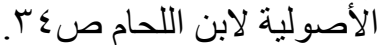

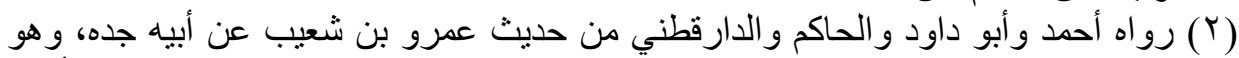

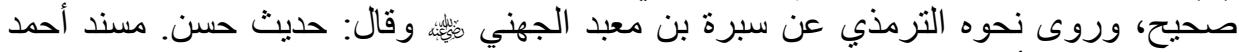

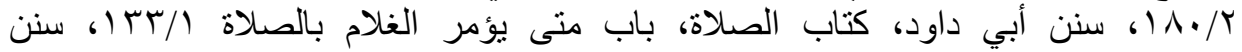

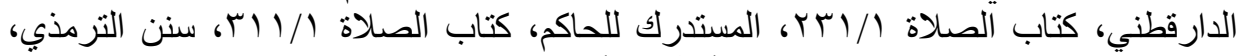

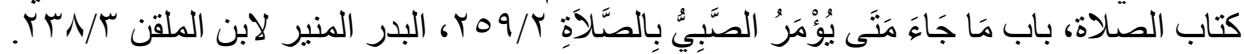

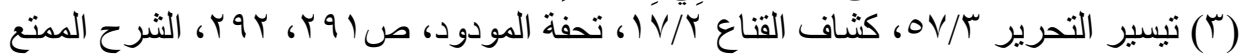

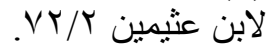

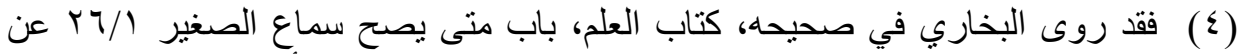

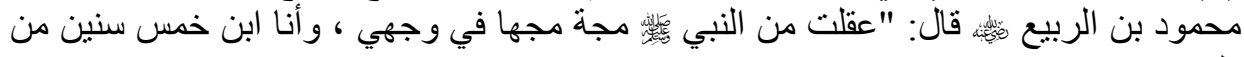

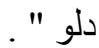

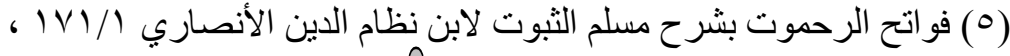




\section{قاميام الصبي بالواجب الكفائي في العباداته}

ويمكن أن يناقش هذا: بأننا نحكم على كل صبي على حدة بكونه مديزاً أو غير مميز من خلال اختباره، والوقوف على حاله، بصرف النظر عن كون وقوع التمييز والحفظ في الأمتلة السابقة قليلاً أو كثيراً. وهناك أقوال أخرى في أن سن التمييز في الصبي هي ست سنين، وفي قول عشر (1). وهذه أقوال لا دليل عليها. والراجح - واله أعلم - أن الصبي المميز هو الذي يفهم الخطاب، ويحسن الجواب ولا يتحدد بسن معينة ، وذللك لأن كل مجتمع من المجتمعات يختلف عن الآخر ، فالمجتمع الذي يهتم بالعلم والتعليم يهتمون بالصبي في سن مبكرة بتعليمه وتثقيفه فيكون مديزاً دون سن السابعة غالباً. ولأن الصبيان يختلفون في حفظه وفهمه ، فبعضهم يحفظ القرآن وهو دون السابعة

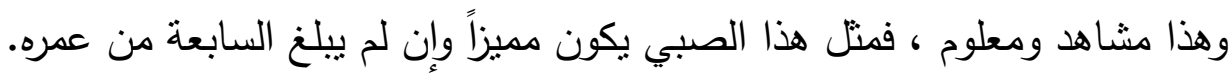
يقول بدر الدين العيني: فَإِن فَهِهَ الْخطاب ورد الْجَواب كَانَ مُمَيَّزا وصحيحَ السماع (يعني سماع الرواية) وَإِن كَانَ دون خمس سنين ل... وَعَنَ إِبْرَاهِيم بن سعيد

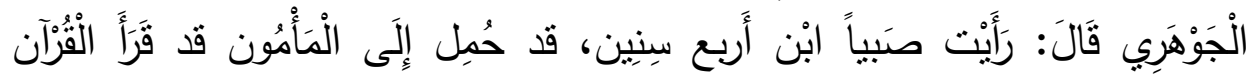

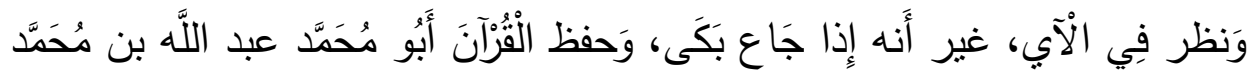

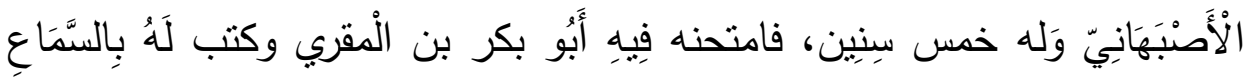

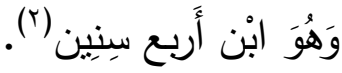

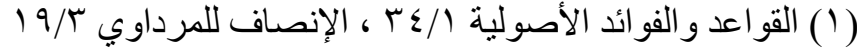

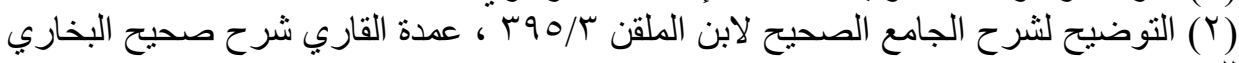

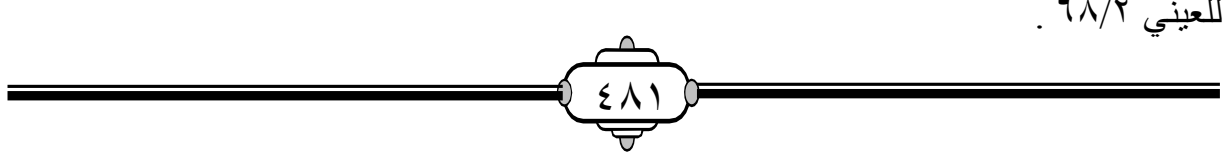




\section{المطلب الثالث: مدى توجه الخطاب الثرعي للصبي}

أجمع أهل العلم على أن الصبي غير المميز غير مكلف ولا مخاطب؛ لأنه لا يفهم خطاب التكليف على الوجه المعتبر ، وبالتالي لا تصح عبر عبادته، إلا الحج إنج

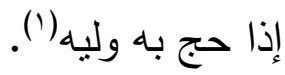

وأما الصبي المميز فقد ذهب أكثر أهل العلم إلى أنه غير مكلف(؟) .

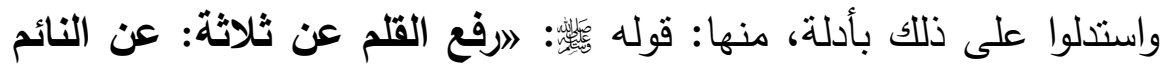
حتى يستيقظ، وعن المجنون حتى يعقل، وعن الصبي حتى يحتلمه(") .

وإذا كان الصبي - سواء كان مميزاً أم غير مميز - غير مكلف، فكيف تجب عليه زكاة أمواله(؛) والنفقات والضمانات؟ والجواب: أن هذه الواجبات ليست

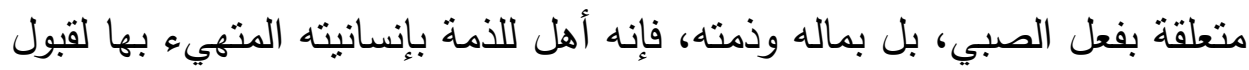

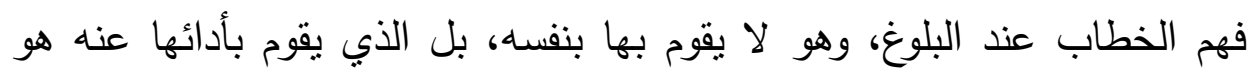

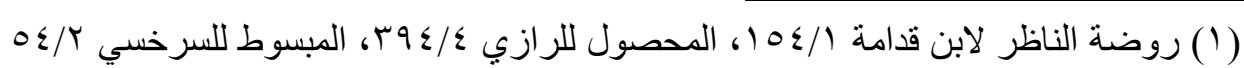

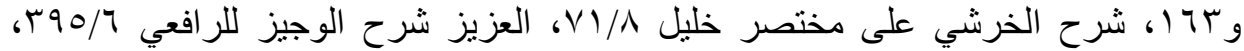

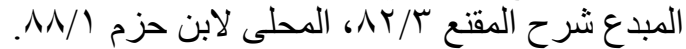

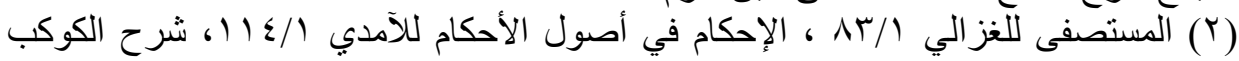

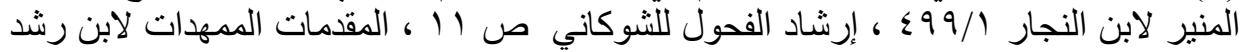

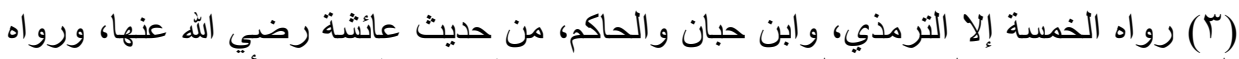

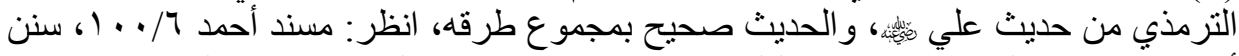

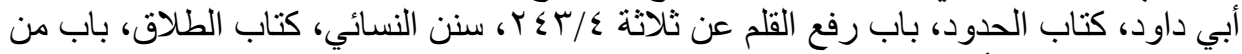

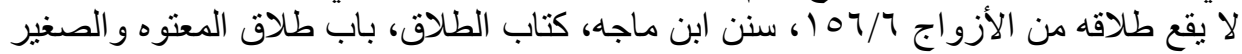

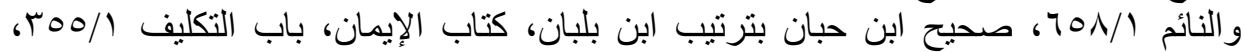

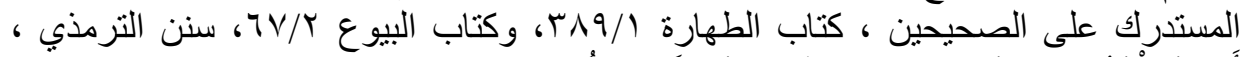

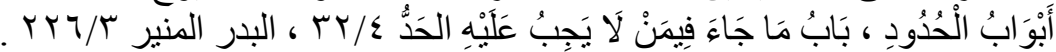

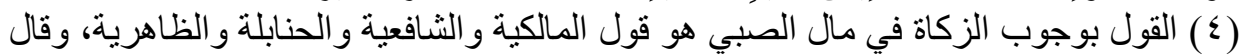

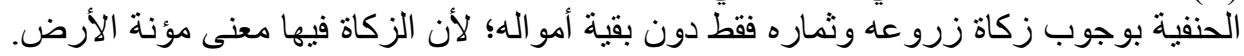

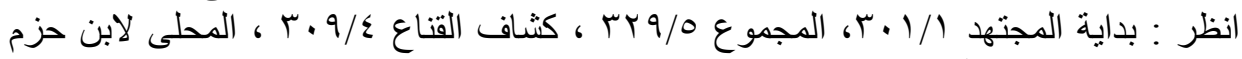

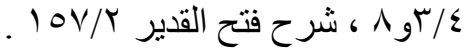




\section{قيام الصبي بالواجب الكفائي في العبادات}

وليه، وهذا من باب خطاب الوضع، وليس من باب خطاب التكليف('). وقد ذهب الإمام أحمد في رواية عنه إلى أن الغلام المراهق الذي قارب الاب الاحتلام تجب بله عليه

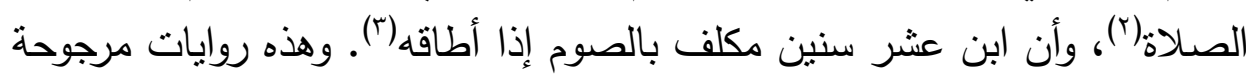
في المذهب أو مؤولة فلا يعول عليهان عُّأ.

كما ذهب المالكية -في المعتمد- وبعض الثافعية إلى أن الصبي المميز مخاطب بالمندوب والمكروه، دون الواجب والمحرم(0). ولكن لا تعارض بين القول بأن الصبي مخاطب بالمندوب والمكروه، وبين القول بعدم تكليف الصبي المميز؛ لأن مخاطبته بهما على سبيل التعويد والتدريب ليألف العبادات، وليس على سبيل التكليف(†)، ولذلك يذهب بعض علماء الأصول إلى أن المندوب والمكروه ليس

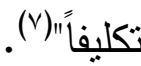

\section{المطلب الرابع: إثابة الصبي على الطاعات}

أجمع أهل العلم(^) على أن الصبي لا تكتب عليه السيئات؛ لأنه مرفوع عنه القلم وهو التكليف، كما ذهب أكثر أهل العلم إلى أن الصبي إذا فعل الطاعات

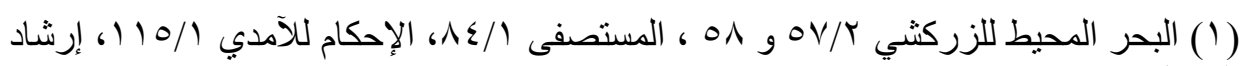

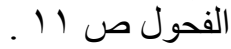

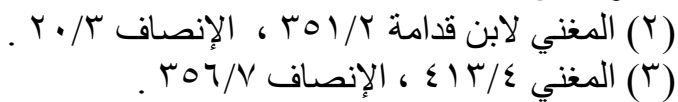

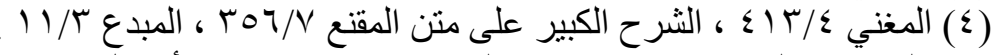

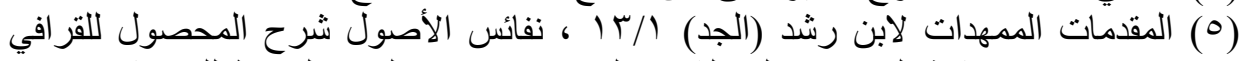

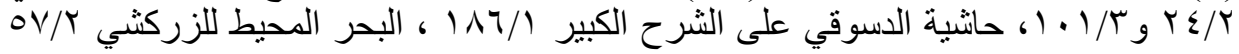

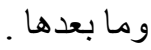

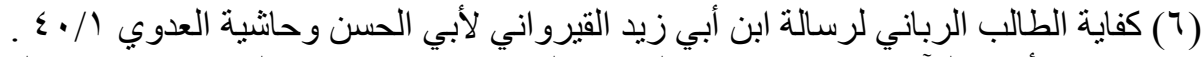

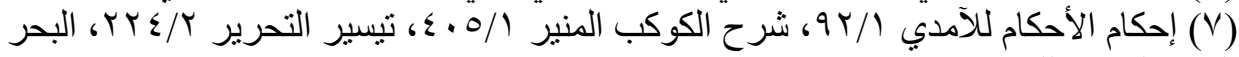

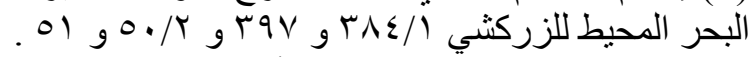

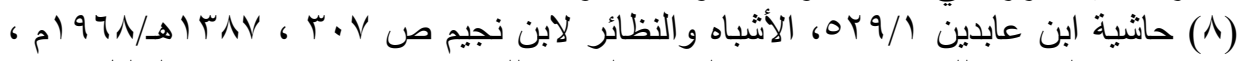

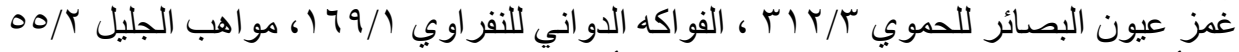

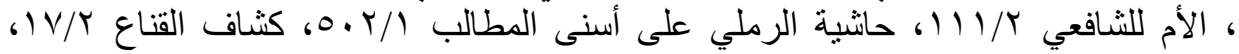

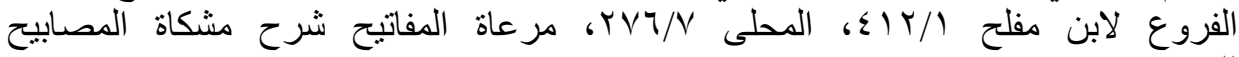

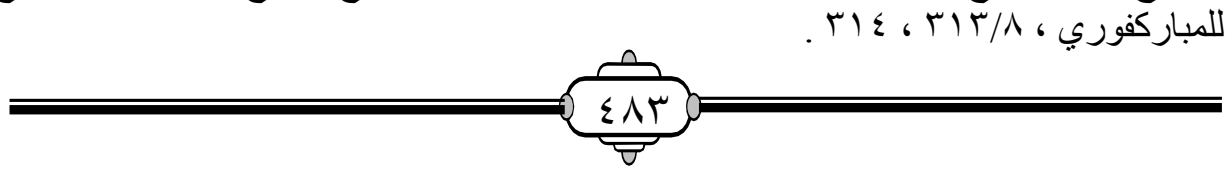


كالصلاة والصوم والحج ونحوها فإن الله كَيَّلت يكتب له الحسنات، بفضله تعالى وَمَنِّهِ

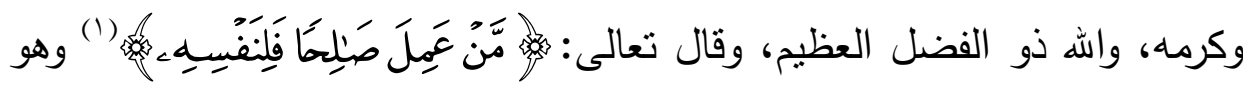

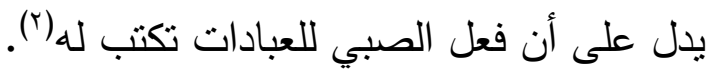

قال أبو عمر بن عبدالبر : أما ما جرى القلم له بالعمل الصالح فغير مستتكر أن يكنب للصبي درجة وحسنة في الآخرة بصلاته وزكاته وحجه وسائر أعمال البر التي يعملها على سنتها، تفضلاً من الله -عز وجل- عليه، كما تفضل على الميت بأن يؤجر بصدقة الحي عنه ويلحقه ثواب ما لم يقصده ولم يعمله مثل الدعاء لله والصلاة عليه، ألانتى أنهم أجمعوا على أمر الصبي إذا عقل الصلاة بأن يصلي،

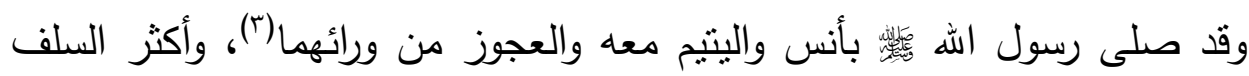
على إيجاب الزكاة في أموال اليتامى، ويستحيل أن لا يؤجروا على ذلك، وكذلك وصاياهم إذا عقلوا، وللذي يقوم بذلك عنهم أجر، كما للذي يحجهم أجر فضلاً من الله ونعمة، فلأي شيء يحرم الصغير التعرض لفضل الله؟ وقد روي عن عمر بن

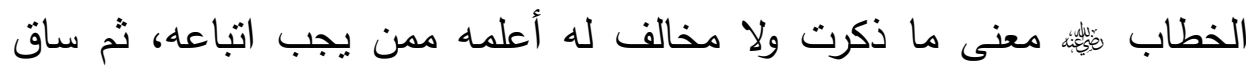

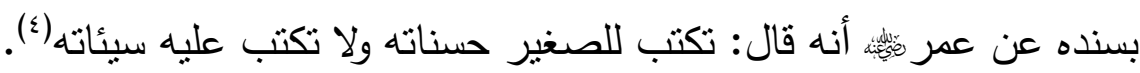
وقال القاضي عياض: قال كثير من العلماء: إن الصبى يثاب على طاعته ويكتب له حسناته دون سيئاته، وروي ذلك عن عمر بن الخطاب، وقد اختلف: هل هم مخاطبون على جهة الندب أم غير مخاطبين، إنما يخاطب أولياؤهم بحملهم

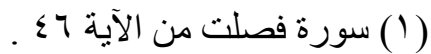

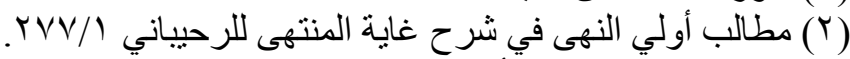

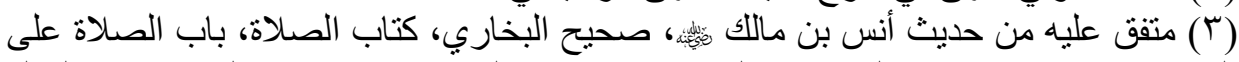

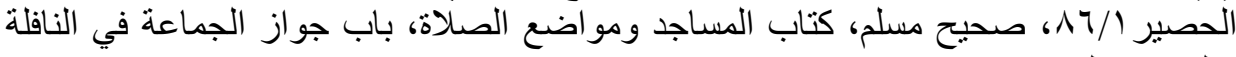

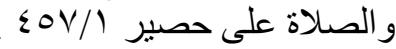

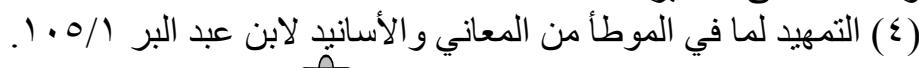


على آداب الثريعة وتمرينهم عليها وأخذهم بأحكامها في أنفسهم وأموالهم؟ وهذا هو الصحيح، ولا يبعد مع هذا أن يتفضل الهه بادخار ثواب ما عملوه من ذلك لهم ('). وقال ابن رشد (الجد): وللصبي فيما دون الاحتلام حالان: حال لا يعقل فيها معنى القربة، وحال يعقل فيها معناها، فأما الحال التي لا يعقل فيها معناها فهو فيها كالبهيمة والمجنون ليس بمخاطب بعبادة ولا مندوب إلى فعل طاعة، وأما الحال التي يعقل فيها معنى القربة فاختلف هل هو فيها مندوب إلى فعل الطاعة كالصلاة والصيام والوصية عند الممات وما أثنبه ذلك، فقيل: إنه مندوب إليه، وقيل: ليس بمندوب إلى شيء من ذللك، وإن وليه هو المخاطب بتعليمه وتذريبه والمأجور على ذللك، والصواب عندي أنهما جميعاً مندوبان إلى ذلك مأجوران عليه، قال رسول اله له

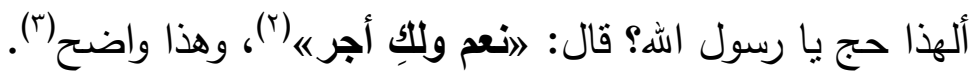
وقال النووي: يكتب للصبي ثواب ما يعمله من الطاعات، كالطهارة والصوم والصلاة والزكاة والاعتكاف والحج والقراءة ... وغير ذللك من الطاعات، ولا يكتب عليه معصية بالإجماع، ودليل هذه القاعدة الأحاديث الصحيحة المشهورة كحديث

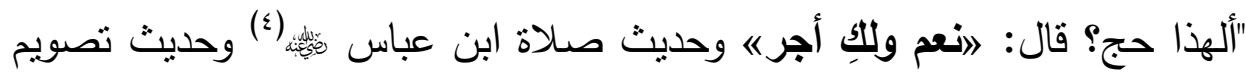
الصبيان يوم عاشوراء، وهو في الصحيحين(0)، وحديث لامروا أولادكم بالصلاة

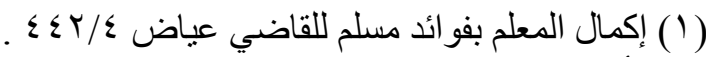

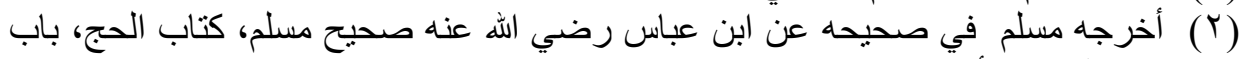

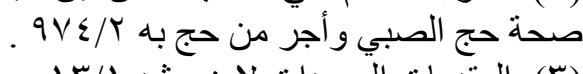

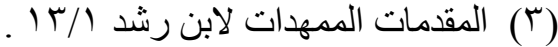

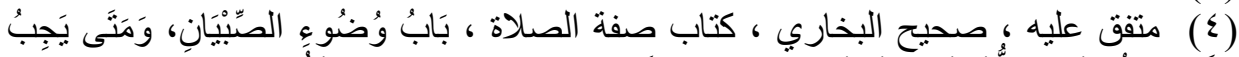

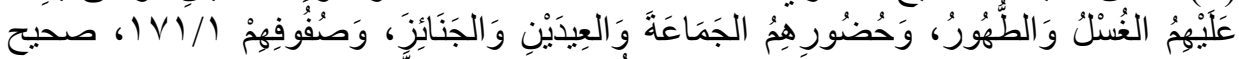

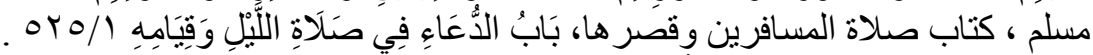

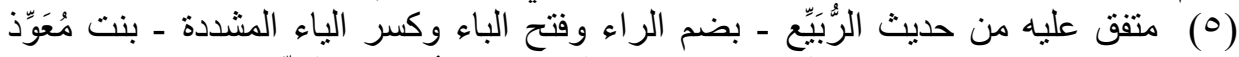

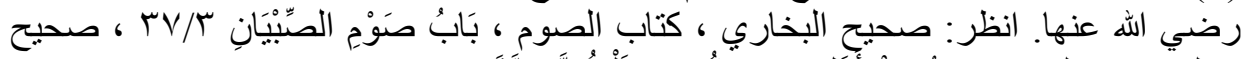

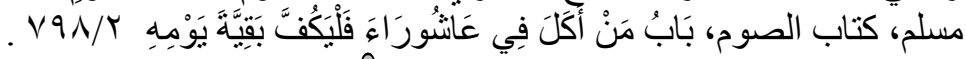

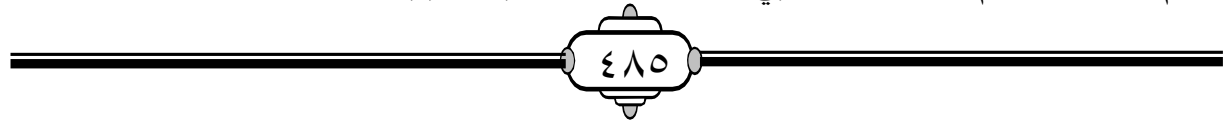




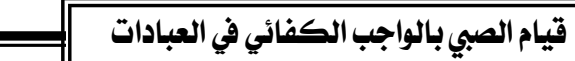

لسبع)، وهو صحيح، وحديث إمامة عمرو بن سَلمِة - بكسر اللام- الْجَرْمِيّ-

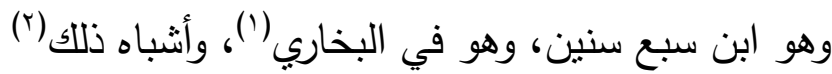

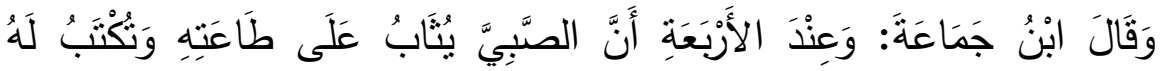

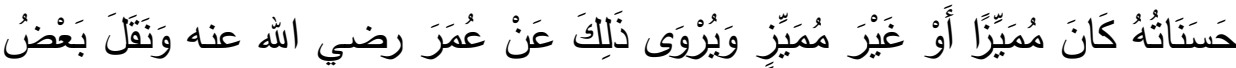

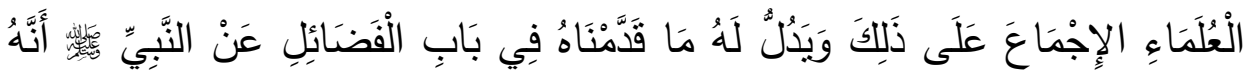

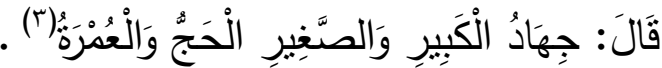

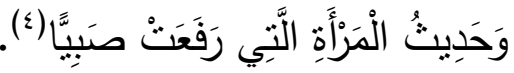

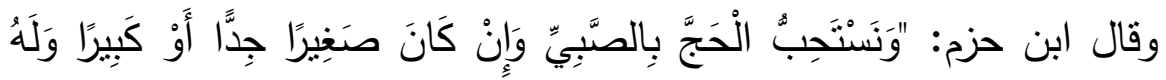

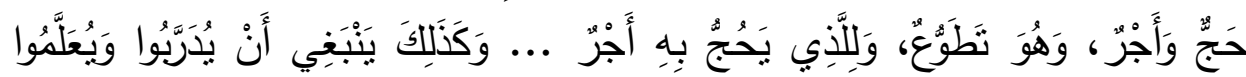

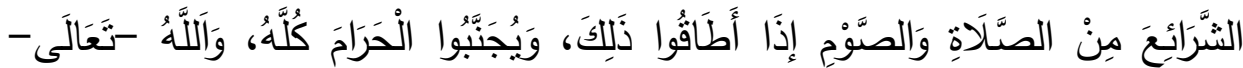

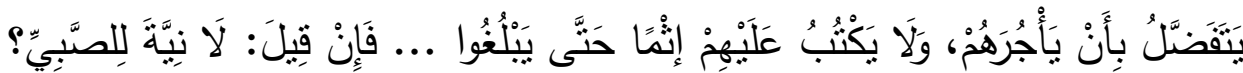

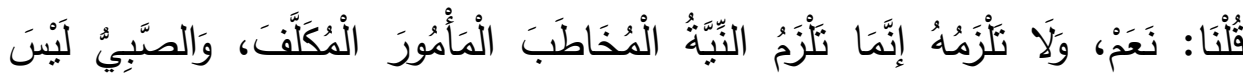

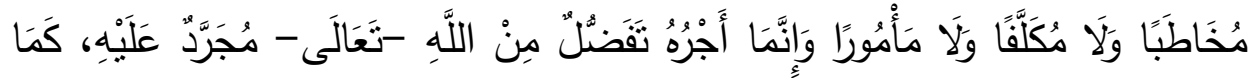

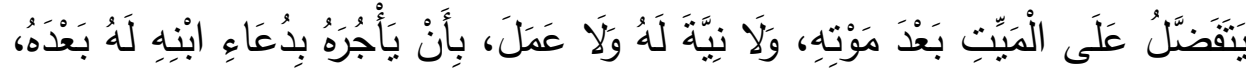

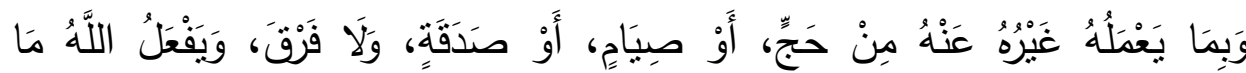

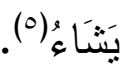

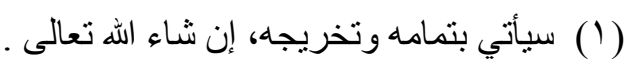

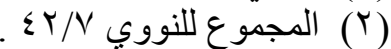

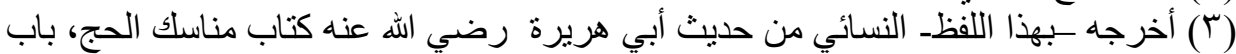

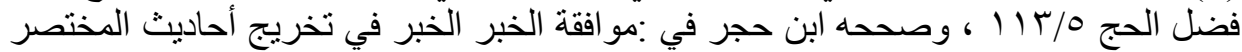

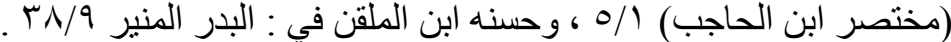

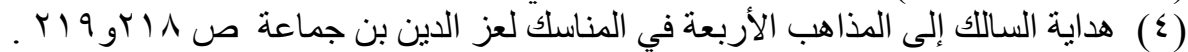

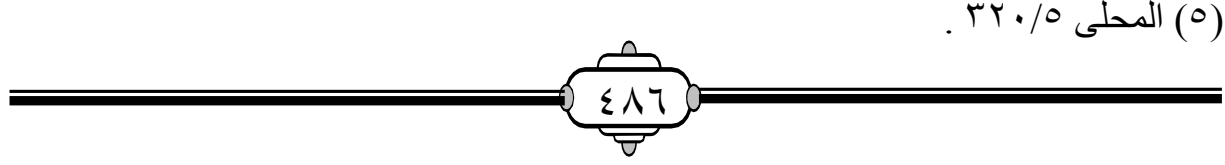




\section{قيام الصبي بالواجب الكفائي في العباداتة}

وكلام ابن حزم كرحمه الله- في أن الصبي لا نبة له لعله أن يحمل على ألى

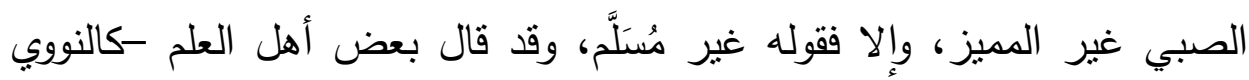

وغيره- إن للصبي المميز نيةً صحيحةً ومعتبرةً شرعاً (1).

(1) المجموع / / (1 ، فيض القدير شرح الجامع الصغير للمناوي // ـ ـ 


\section{المبحث الثاني \\ تعريف الواجب الكفائي وبيان فضله}

\section{وفيه مطلبان:}

\section{المطلب الأول: تعريف الواجب الكفائي وذكر أقسامه بإيجاز}

الواجب لغة: يطلق على عدة معان، منها الثبوت واللزوم، يقال: وجب البيع: إذا ثبت ولزم، ومنها السُقوط والوقوع، يقال: وجَب الرجل: أي سقط إذا مات،

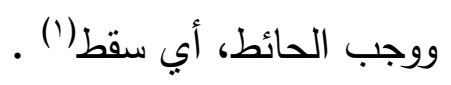
الواجب شرعاً: عرف علماء الأصول الواجب بتعريفات كثيرة:

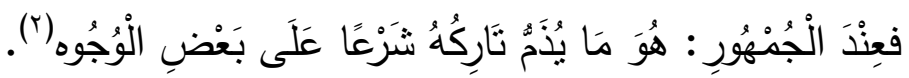

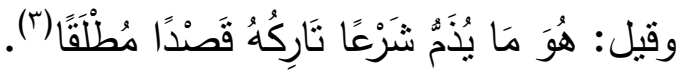
أما الحنفية(؛) وبعض الحنابلة() الذين يفرقون بين الفرض والواجب فقد عرفوا

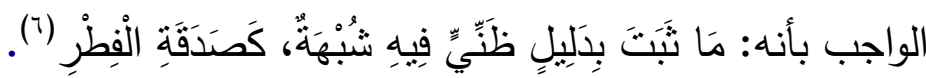

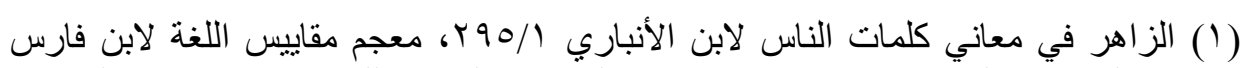

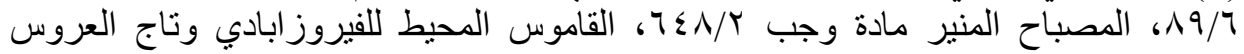

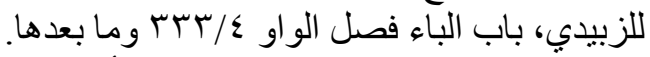

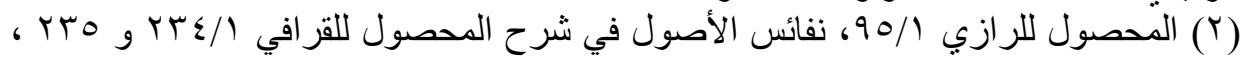

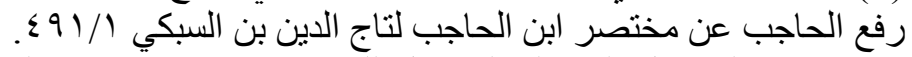

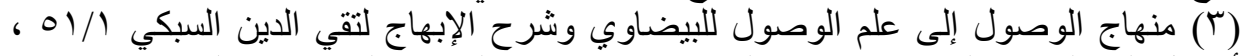

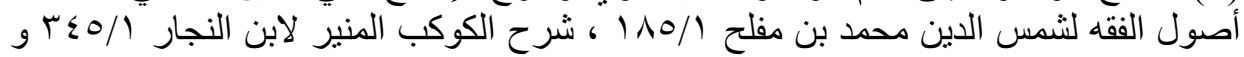

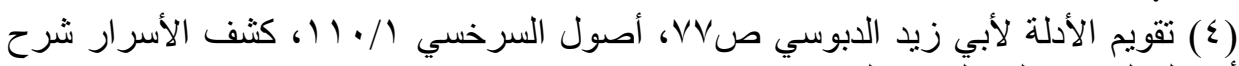

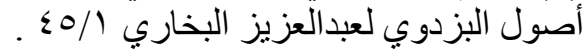

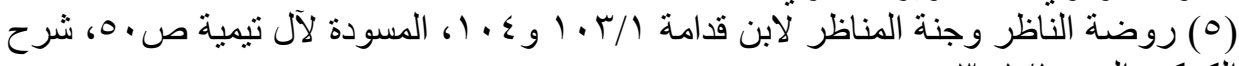

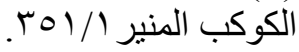

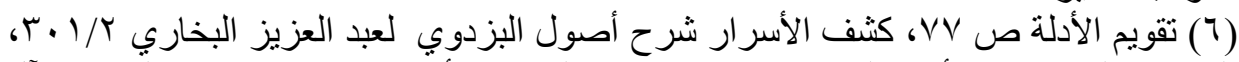

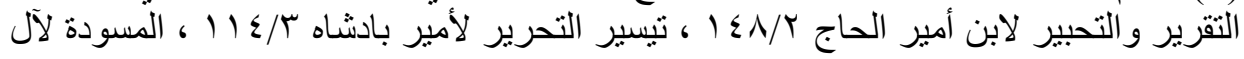

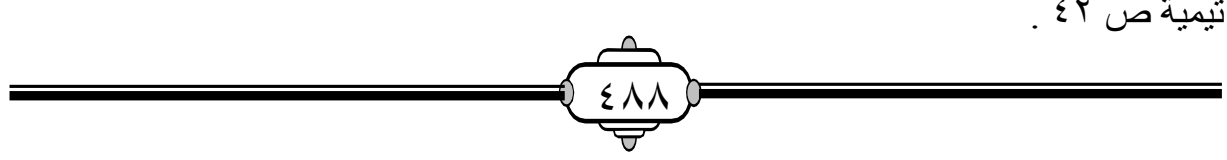




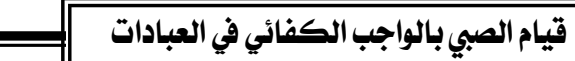

أما الفرض: فعرفوه بأنه: ما ثبت بدليل قطعي لا شبهة فيه(') وسأسبر في

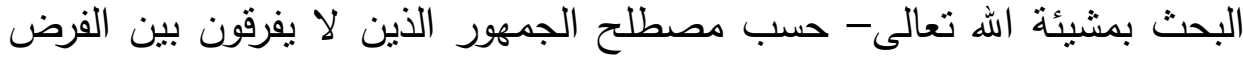

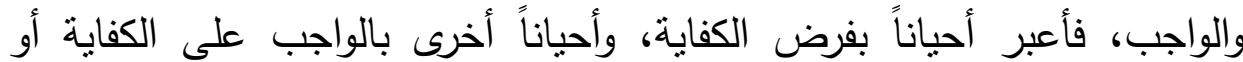
بالواجب الكفائي.

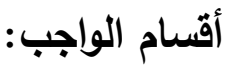

للواجب أقسام كثيرة، باعتبارات متعددة، ليس هذا مجال بحثها، لكن الذين يعنينا ويناسب البحث هو أن الواجب ينقسم بحسب فاعله: إلى واجب عيني ، باعبال وواجب كفائي.

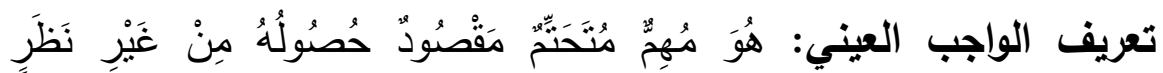

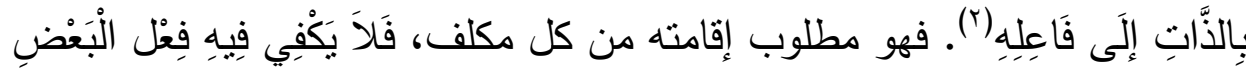

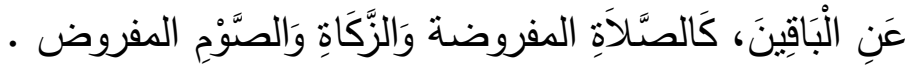
تعريف الواجب الكفائي: قال الغزالي في تعريفه: كل مهم ديني يراد حصوله وَلا يقصد به عين من بتولاه(r). ومعناه: أنَّ الواجبات الكفائية أمور كلية تتعلَّق بها

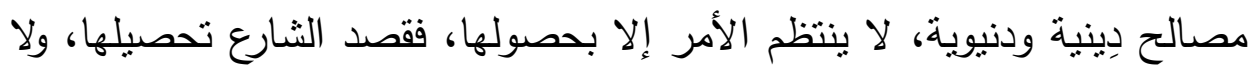

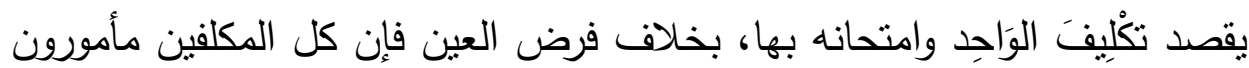

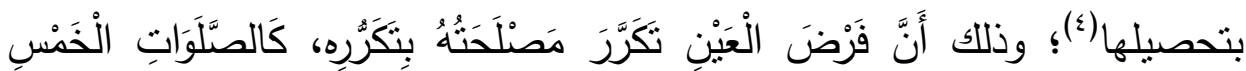

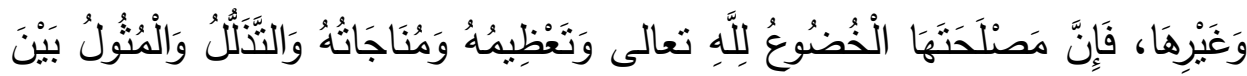

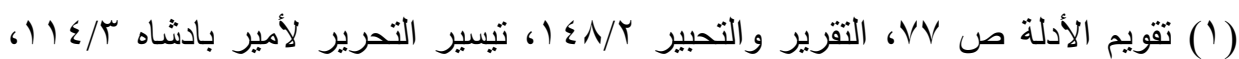

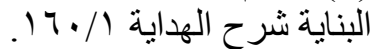

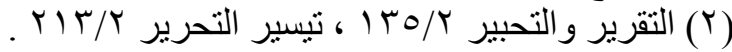

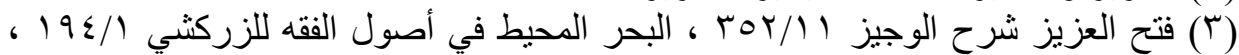

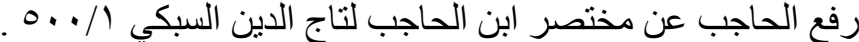

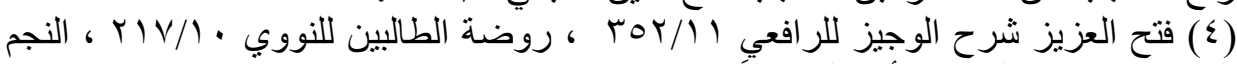

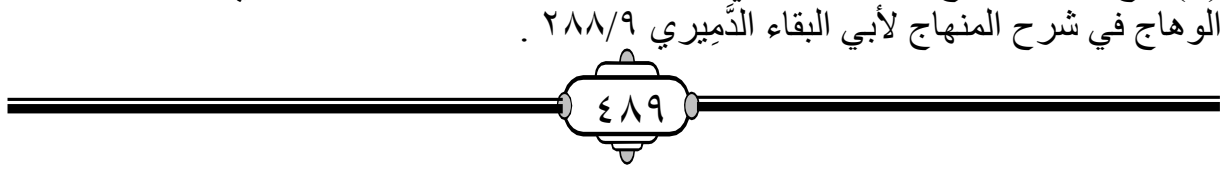




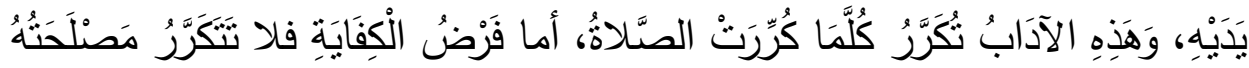

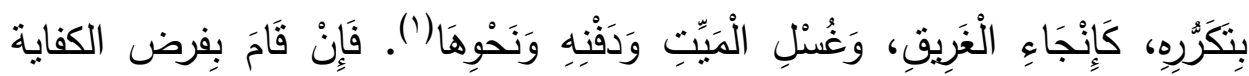

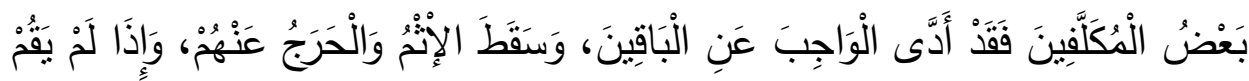

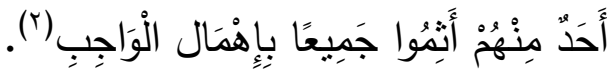

\section{أقسام فرض الكفاية: ينقسم فرض الكفاية باعتبار متعلقه قسمين(')}

الأول: فروض الكفاية الدينية، متل الاشتغال بسائر علوم الثريعة، كالتفسير والحديث والفقه وأصوله، وتصنيف كتب العلم، والاجتهاد في الثريعة، وتولي التئي

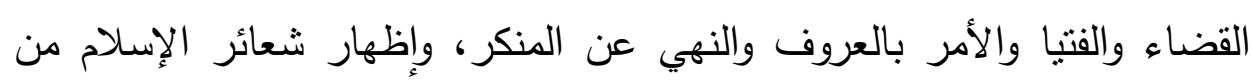

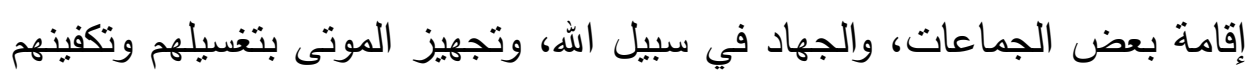

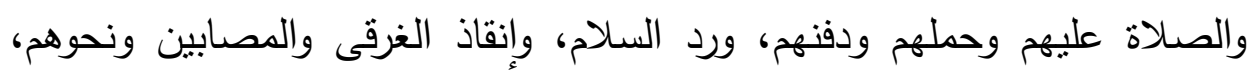
والتقاط المنبوذ (اللقيط).

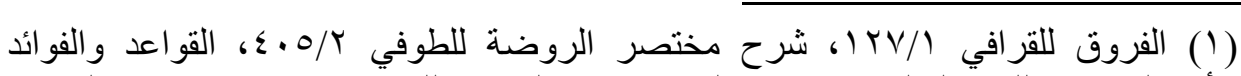

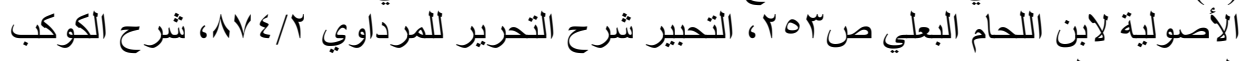

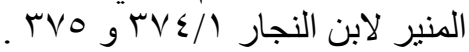

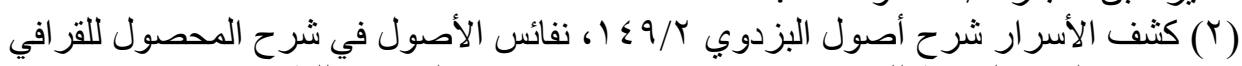

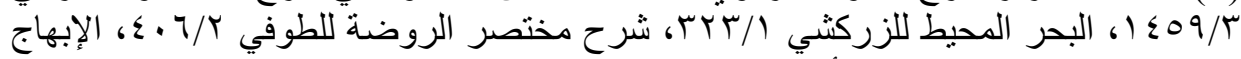

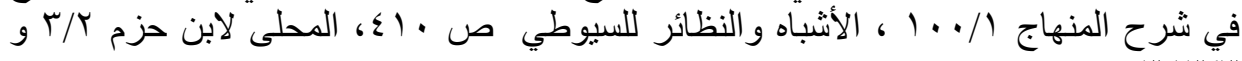
.

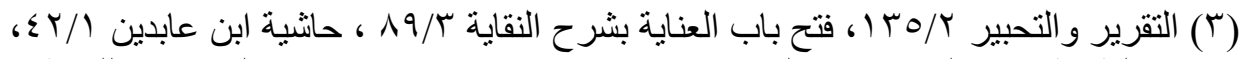

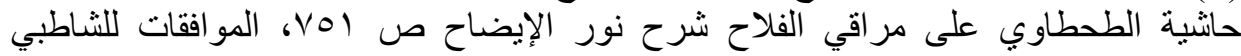

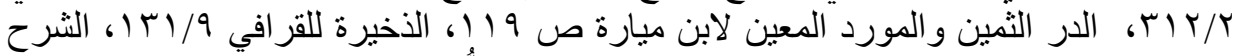

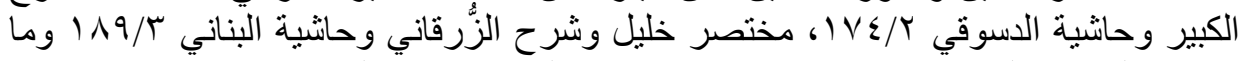

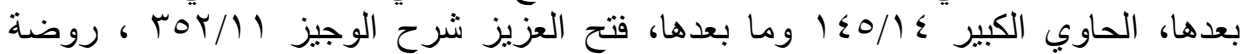

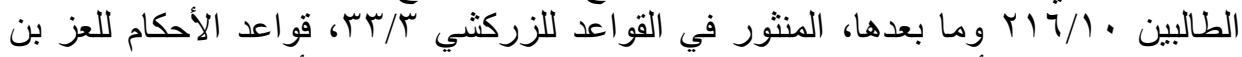

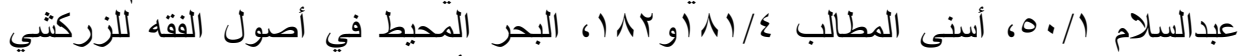

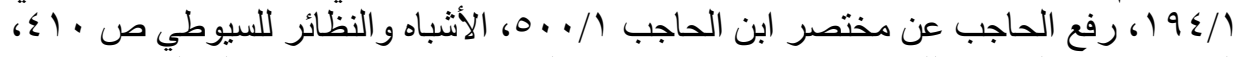

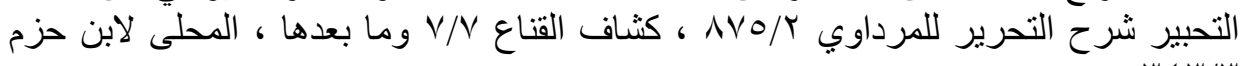

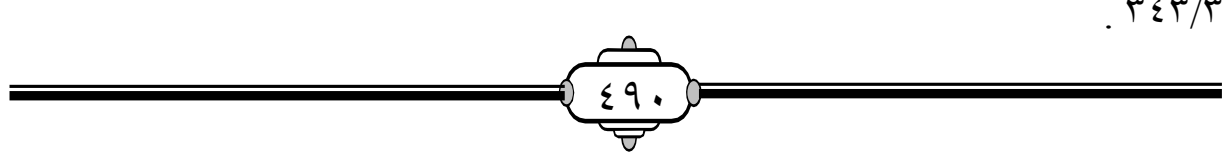




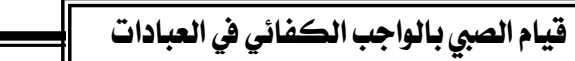

الثاني: فروض الكفاية الدنيوية، كالاشتغال بالعلوم الدنيوية النافعة، كالطب والهنسة والرياضيات والكيمياء وعلوم الاقتصاد والعلوم الاجتماعية والتقنية، والقيام بما فيه قوام المعاش من حرف ومهن، كالزراعة والفلاحة والصناعات، ونحوها . المطلب الثاني: فضل الواجب الكفائي إن من يقوم بفرض الكفاية له أجر عظيم وثواب عميم، وقد قصد الثارع الحكيم من تثريعه حفظ مصالح الناس العامة، ودرء المفاسد عنهم، مما يتعلق بالأمور الضرورية المجتمعية في شتى مناحي الحياة.

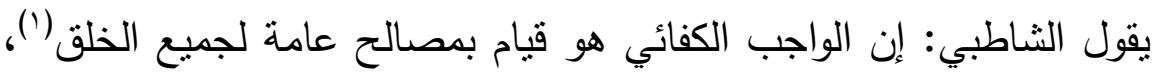
وقال العز بن عبدالسلام: اعلم أن المقصود لفرض الكفاية تحصيل الدصالح ودرء المفاسد دون ابتلاء الأعيان بتكليفه(ب). وقد اختلف العلماء: أيهما أفضل وأولى: القيام بفرض الكفاية أم بفرض دالان

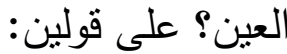
القول الأول: إن فرض العين أفضل وأولى من فرض الكفاية، وهو قول جمهور العلماء("). واستدلوا على ذلك بما يأتي :

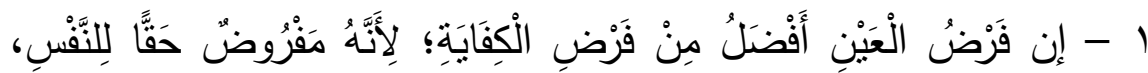

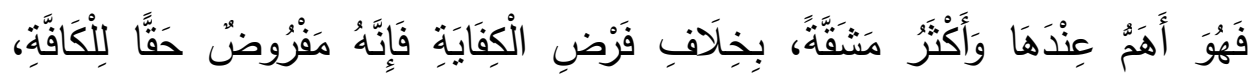

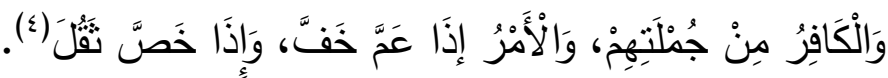

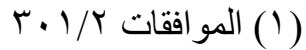

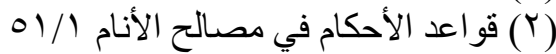

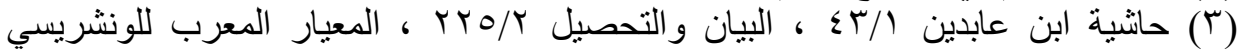

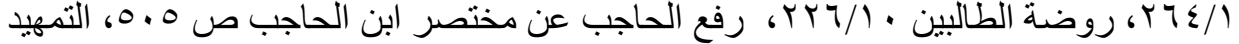

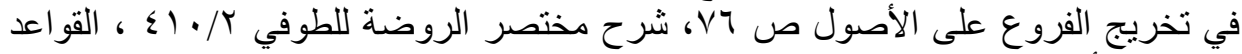

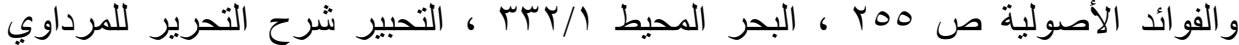




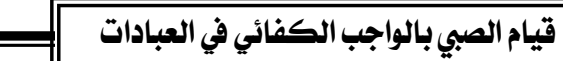

r - إن النصوص الثرعية قدمت فرض العين على فرض الكفاية، من ذلك

تقديم بر الوالدين، وهو فرض عين، على الجهاد في سبيل الله، وهو فرض كفاية .

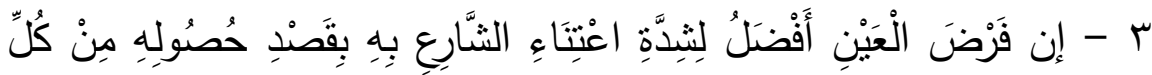

مُكَلَّفْ فِي الْأَغْلَبِ (1).

القول الثاني: القيام بفرض الكفاية أولى، وإليه ذهب محمد وبعض الحنفية والمالكية في قول وبعض الثافعية كأبي إسحاق الإسفراييني وإمام الحرمين الجويني ووالده والغزالي والنووي وبعض الحنابلة(؟).

\section{واستدلوا على ذلك:}

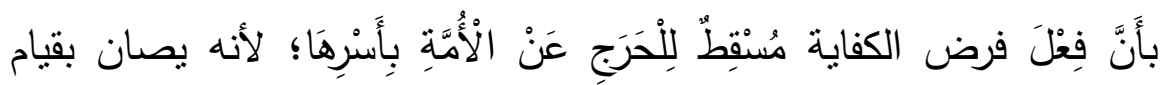
البعض به جميع المكلفين عن الإثم المرتب على تركهم له، وفرض العين بسقط

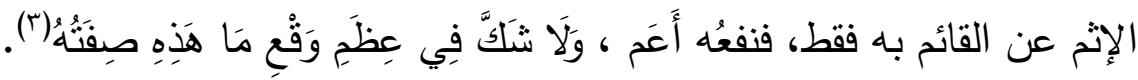

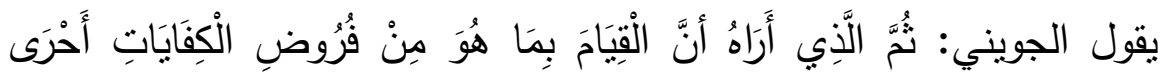

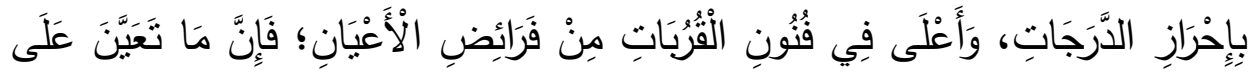

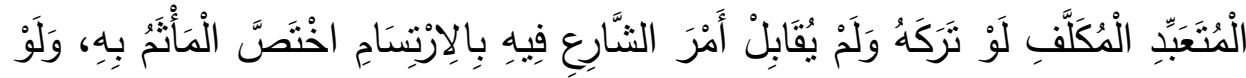

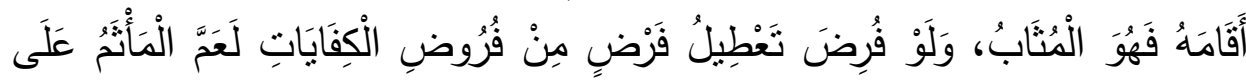

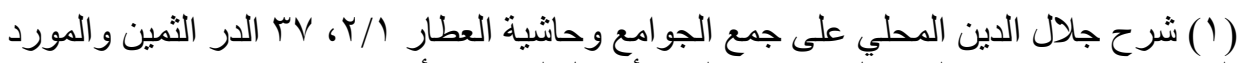

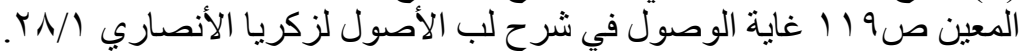

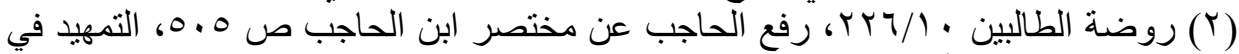

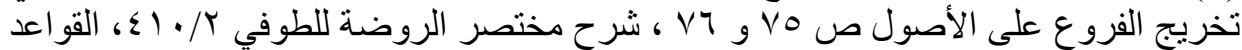

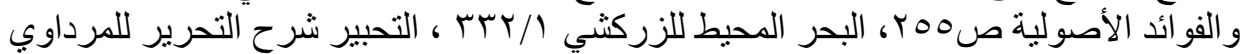
. ANr/r

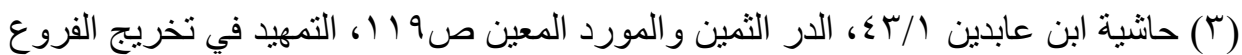

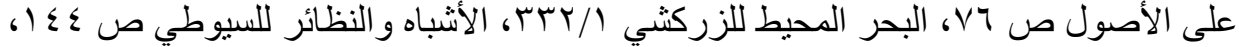

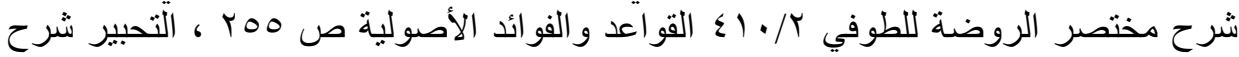

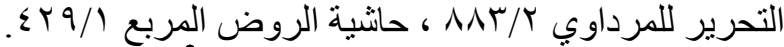




\section{قيام الصبي بالكواجب الكفائي في العباداته}

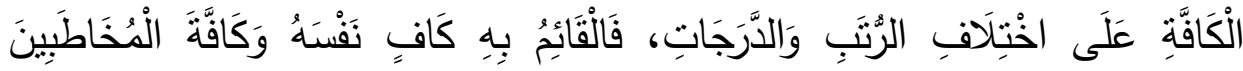

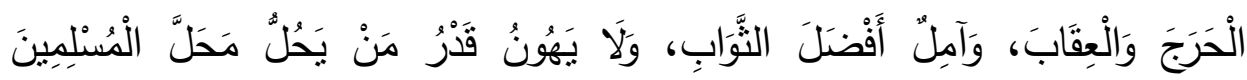

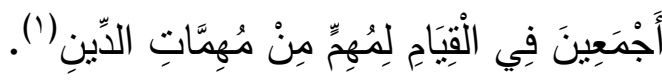
وقد جمع بعض العلماء بين القولين فقال: مَا ذَكَرَ مِنْ تَفْضِيلِل فَرْضِ الْكِفَيَةِ

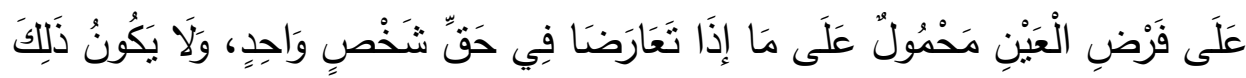

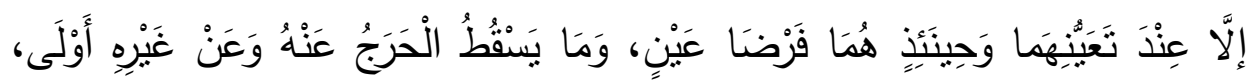

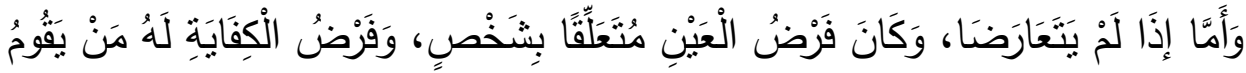

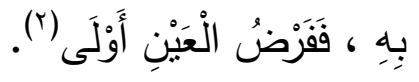

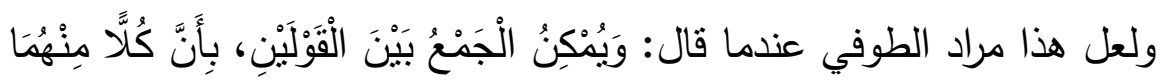

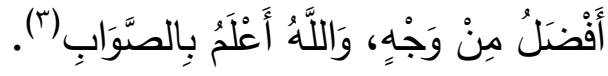

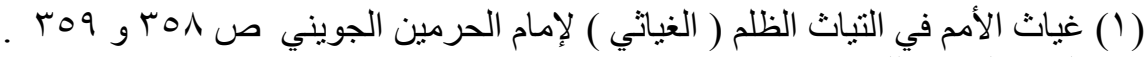




\section{قيام الصبي بالواجب الكفائي في العباداتص}

\section{المبحث الثالث \\ قيام الصبي بالواجب الكفائي في الأذان والصلاة \\ وفيه ثثلاثة مطالب}

المطلب الأول: حكم أذان الصبي وإقامته

أتناول في هذا المطلب حكم الأذان التكليفي، ثم أبين حكم أذان الصبي: هل يصح ويجزئ حتى مع وجود البالغين أم لا ؟ وذلك في الفرعين الآتيين :

\section{القرع الأول: حكم الأذان}

اتفق الفقهاء على مشروعية الأذان والإقامة للصلوات الخمس المفروضة والجمعة، ولكنهم اختلفوا في هذه المشروعية: هل هي على سبيل الوجوب أم الندب؟ على عدة أقوال:

القول الأول: إن الأذان والإقامة فرض كفاية للصلوات الخمس المفروضة والجمعة غير شرط لصحة الصلاة، وإليه ذهب بعض الحنفية، ونقله بعضهم عن

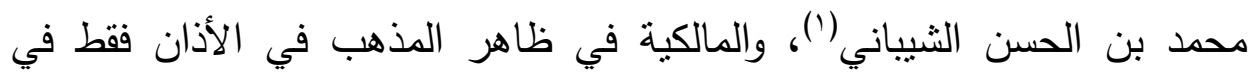
مساجد الجماعات في الأمصار(؟)، والثافعية في وجه(؟)، والحنابلة في الصحيح

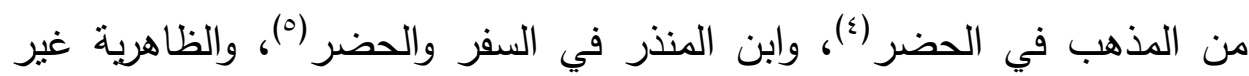

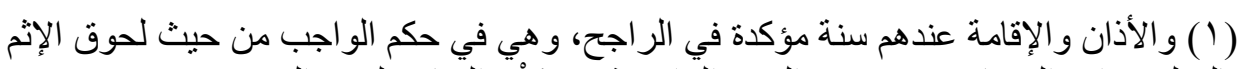

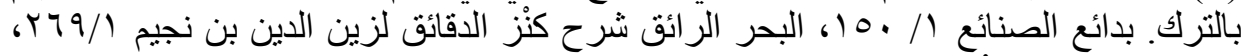

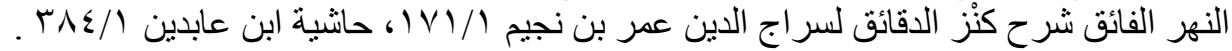

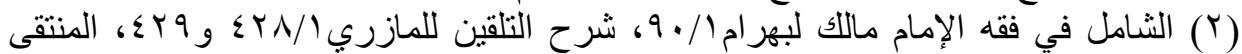

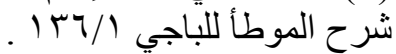

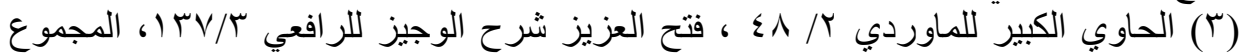

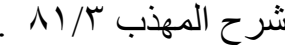

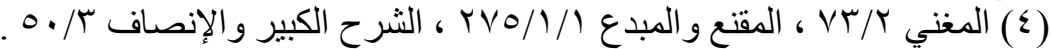

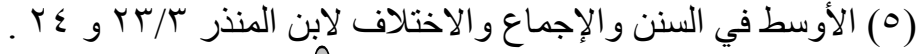




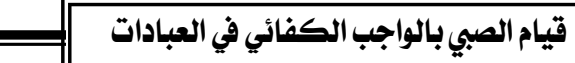

أنهم قالوا: لا تصح الصلاة بدون أذان وإقامة(')، ووافق الظاهريةً عطاءٌ ومجاهدٌ

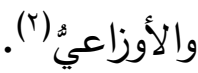

القول الثاني: إن الأذان سنة، وإليه ذهب الحنفية في الراجح عندهم(؟)،

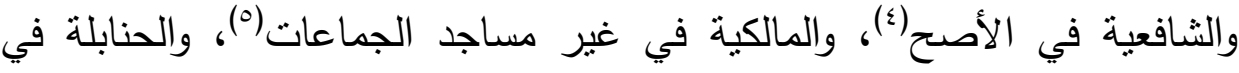
رواية في الأمصار، وفي رواية أخرى مطلقاً (ب).

القول الثالث: إن الأذان فرض والإقامة سنة، وإليه ذهب المالكية القائلون بأن

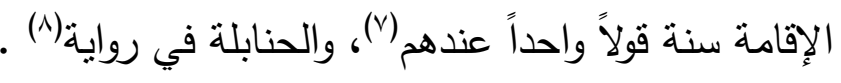

القول الرابع: إن الأذان واجب للجمعة، سنة في غيرها، وإليه ذهب المالكية

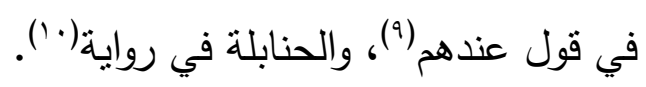

الأدلة: سأقتصر على ذكر أدلة من قال بالوجوب، ومن قال بالسنة، دون

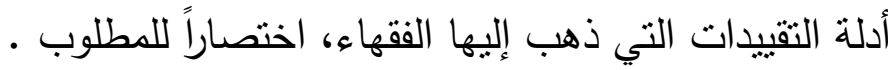
أولاً: أدلة من قال بوجوب الأذان والإقامة: استدلوا بما يأتي :

1 - حديث مالك بن الحويرث رضي الله عنه، وفيه قول رسول الله

فإذا حضرت الصلاة فليؤذن لكم أحدكم ، وليؤمكم أكبركمه" (') .

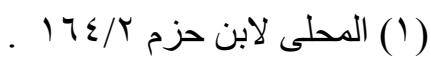

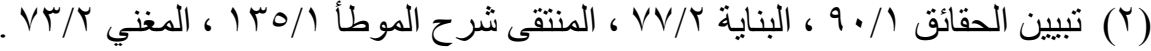

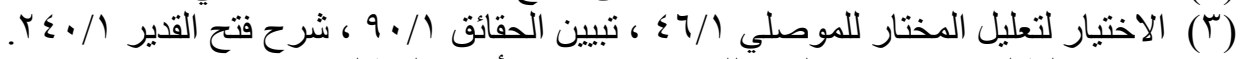

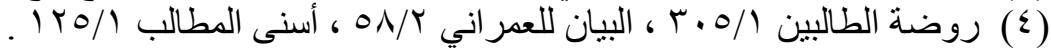

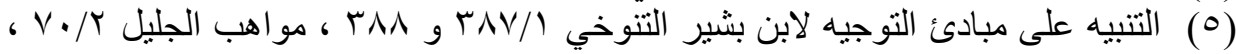

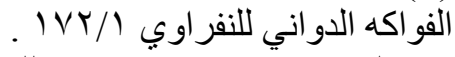

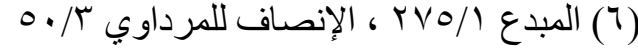

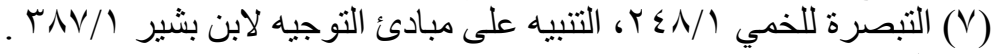

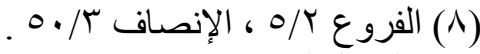

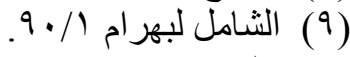

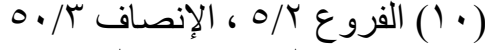

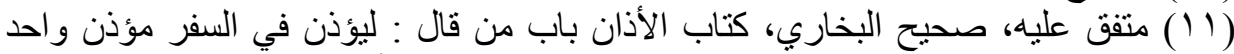

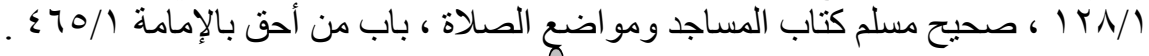


r - حديث عمرو بن سلَمِة -بكسر اللام- الْجَرْي -بفتح الجيم وسكون

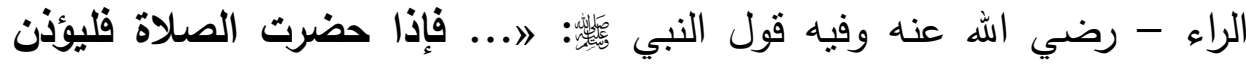
أحدكم، وليؤمكم أكثركم قرآناً) (').

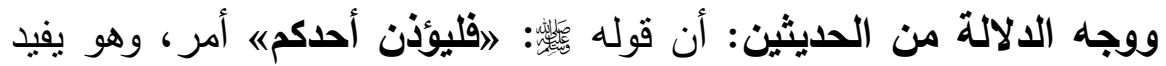
الوجوب، فإذا قام به واحد سقط عن الباقين(؟). وتدخل الإقامة في هذا الأمر، بدليل بدليل أن النبي

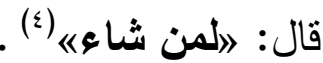

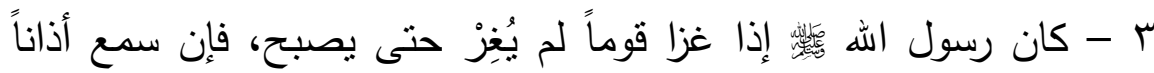
أمسك، وإن لم يسمع أذاناً أغار بعدما يصبح"(o). وهذا يدل على أن الأذان شعار الإسلام وداره -أبي علامة بلاد الإسلام- فكان

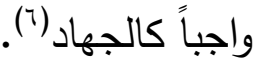

؟ - عن أبي الدرداء رضي الله عنه عن النبي

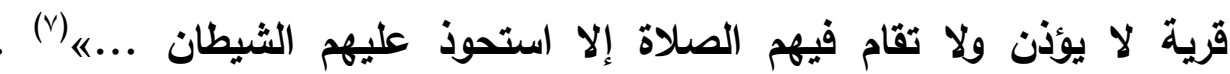

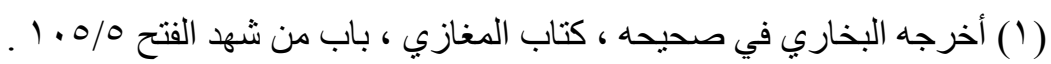

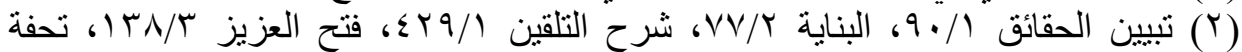

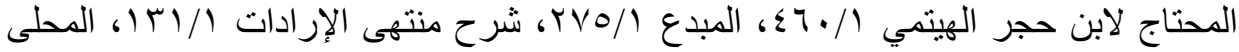

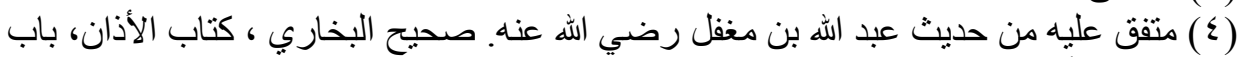

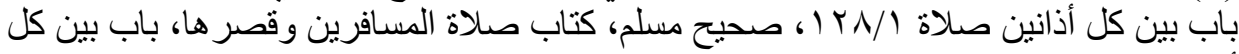

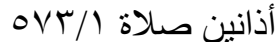
(0) متفق عليه من حديث أنس. صحيح البخاري، كتاب الأذان، باب ما يحقن بالأذان من الأداء الإناء

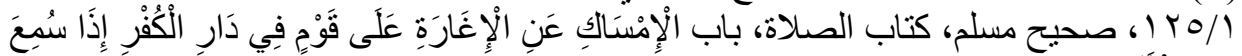

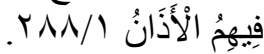

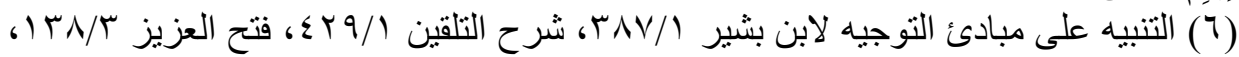

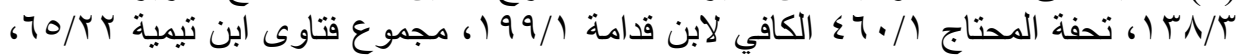

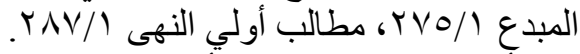

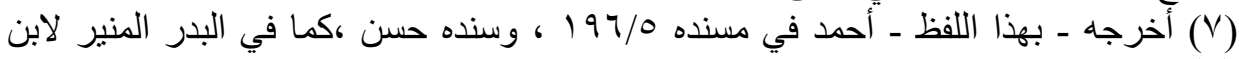

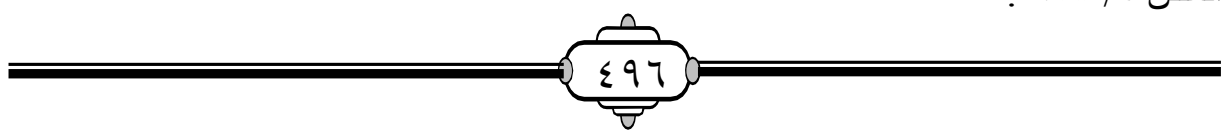




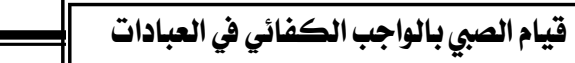

والحديث فيه دلالة على وجوب الأذان؛ لأن تركه يؤدي إلى استحواذ الثيطان، وهو

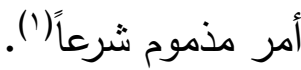

0 - مداومة النبي كُّك وخلفائه رضي الله عنهم من بعده يدل على وجوبه،

وكان يكتفي بأذان بلال رضي اله عنه ، مما يدل على أنه فرض كفاية(؟) .

ثانياً: أدلة من قال بأن الأذان والإقامة سنة : استدلوا بالآتي :

1 - حديث المسيء صلاته، وفيه قول النبي

فأسبغ الوضوء ثم استقبل القبلة ، فكبر ثم اقرأ بما تيسر معك من القرآن ...

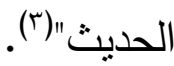

ووجه الدلالة منه: أن النبي

الوضوء واستقبال القبلة وأركان الصلاة، ولم يذكر له الأذان ولا الإقامة، ولو كانا

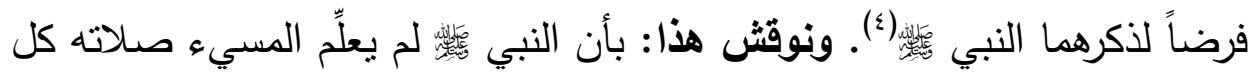

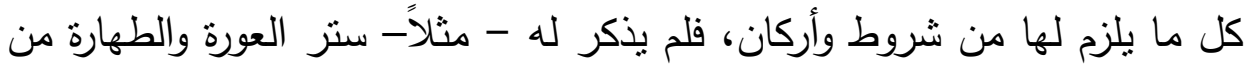

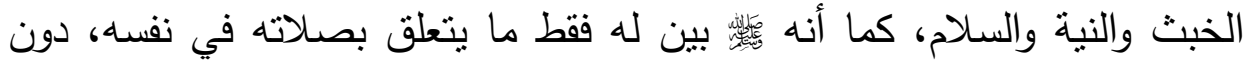

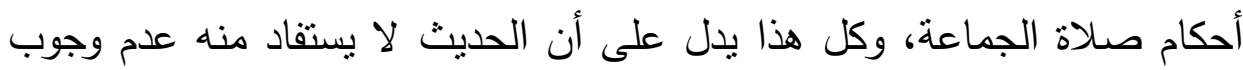

الأذان والإقامة (o).

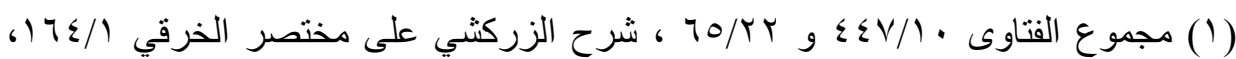

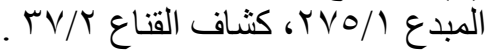

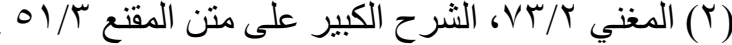

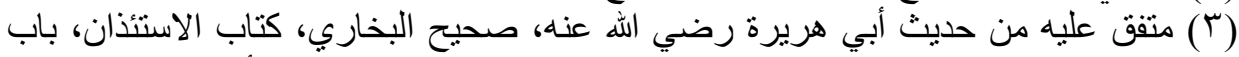

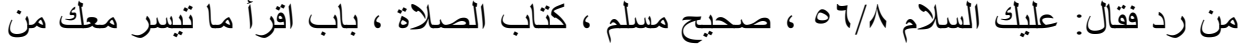

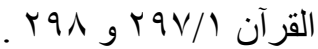

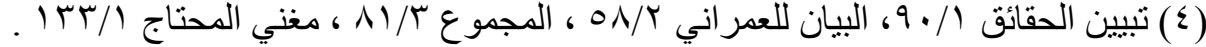

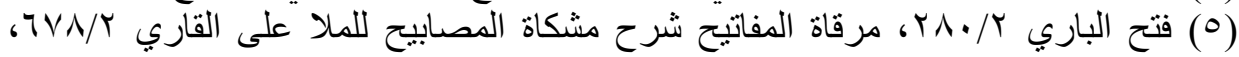

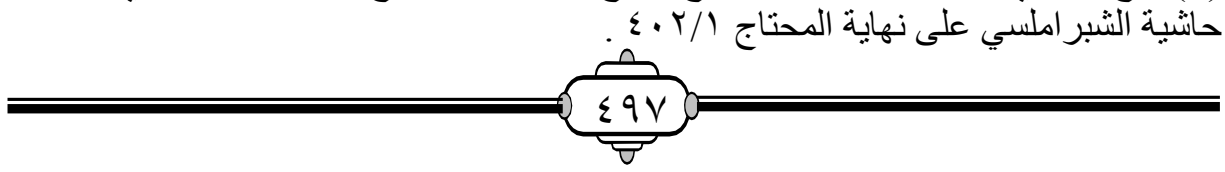




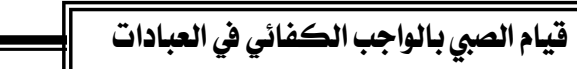

r - أن النبي بَ

الثانية(')، والجمع سنة، فلو كان الأذان واجباً لما تركه لسنة (؟).

ويمكن أن يناقش هذا: بأن المقصود من الأذان الإعلام، وقد تحقق هذا بالأذان للأولى والتي تعقبها الصلاة الثانية، فلا حاجة للأذان للانانية، أما الإقامة الإنا فالمقصود منها الدعاء لللخول في الصلاة، ولذلك تكررت في الثانية للحاجة إليها. r - إن الأذان والإقامة شُرعا للإعلام بدخول والدعاء للصلاة، فلم يجبا،

كقول: الصلاة جامعة في العيدين ونحوهما (ץ).

ونوقش هذا: بأن هناك فرقاً بين الأذان والإقامة وبين القول: الصلاة جامعة؛

إذ الأذان والإقامة شعار ظاهر للإسلام، بخلاف "الصلاة جامعة " فليس شعاراً (؛). القول الراجح: والراجح حواله أعلم- هو القول الأول وهو وجوب الأذان والإقامة للصلوات الخمس المفروضة في جماعة وللجمعة، على سبيل الكفاية؛ لما سبق من أدلة، ولأنه بتم العلم بدخول الوقت والدعاء للصلاة بهما غالباً، ولأنها شعار من شعائر الإسلام الظاهرة(ه). ويكفي في المساجد المنقاربة في الحي أذان واحد، لحصول المقصود من الإعلام والدعاء للصلاة وإظهار الثعار • وقد سئلت اللجنة الدائمة للبحوث العلمية والإفتاء: هل من الواجب الأذان في جميع المساجد بمكبرات الصوت في حي واحد، مع العلم أن المسجد الواحد يسمعه جميع المسلمين

(1 ) صحيح البخاري ، كتاب الدج، باب من أذن و أقام لكل واحدة منهما / / ع 1 ، ، صحيح مسلم،

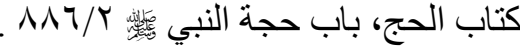

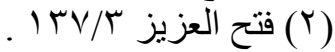

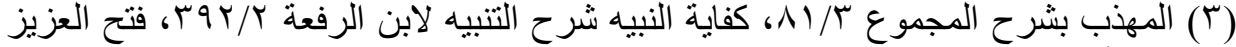

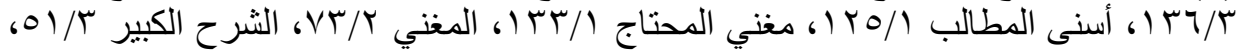

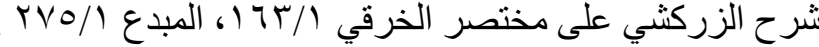

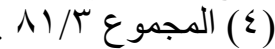

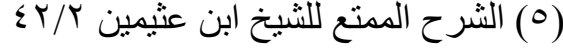


(يعني في الحي)؟ وهل يكفي الأذان في مسجد واحد من مساجد الحي؟ فكان الجواب: الأذان فرض كفاية، فإذا أذن مؤذن في الحي فأسمع سكانه أجزأهم ('). الفرع الثاني: حكم أذان الصبي

إذا قلنا: إن الأذان والإقامة فرض كفاية، إذا قام بهما البعض سقط عن الباقين، فهل يجزئ أذان الصبي مع وجود البالغين؟. اتفق الفقهاء على أن أذان الصبي غير المميز لا يصح؛ لأنه ليس من أهل العبادة، كما سبق، ولأن صوته كصوت الطيور، فلا يعتد به (؟).

ثم اختلفوا في أذان وإقامة الصبي المميز :هل يسقط بهما فرض الكفاية أم لا؟. على ثلاثة أقوال: القول الأول: إن أذان الصبي المميز صحيح مجزئ. وإليه ذهب الحنفية(ץ)، والمالكية في قول عندهم(๕)، والثافعية() ، والحنابلة في في الصحيح من المذهب(")، وهو قول عطاء والثعبي وابن أبي ليلى وابن

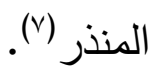

القول الثاني: عدم صحة أذانه، وإليه ذهب المالكية في المذهب(')، والحنابلة

$$
\text { في رواية(r) والظاهرية(ب). }
$$

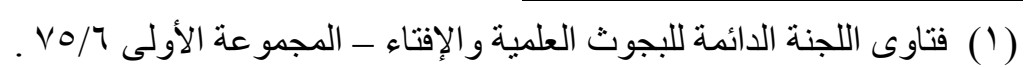

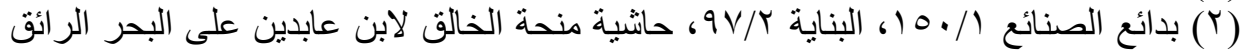

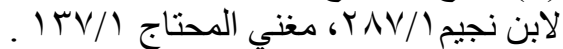

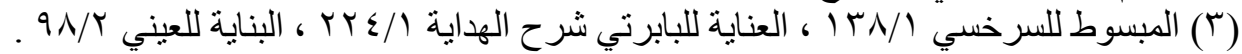

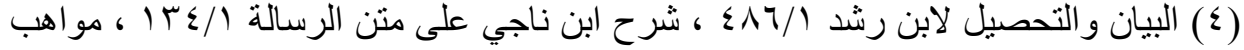

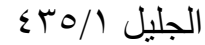

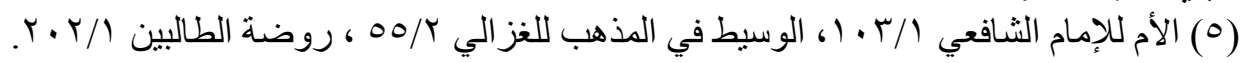
$r \cdot r / 1$

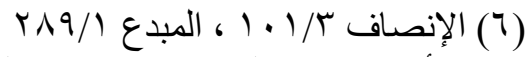

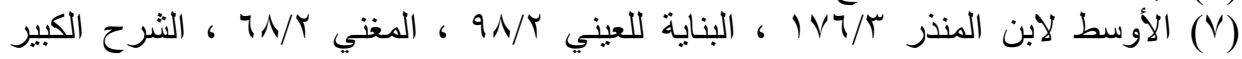
$=\overbrace{\frac{599}{\sigma}}^{c}=$ 


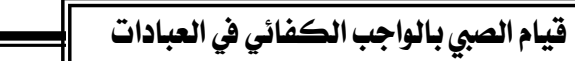

القول الثالث: التفريق بين حالين: الأولى: أن يستقل الصبي بتحديد الوقت فيؤذن دون البالغين، ويعتد عليه في الصلاة والصيام، فهذا لا يصح من الصبي الصي

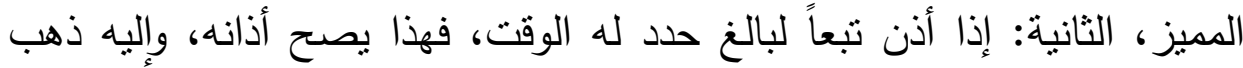

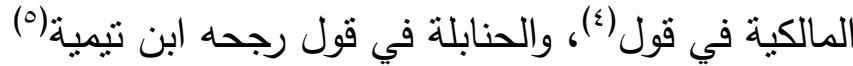
الأدلة:

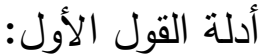

استنل القائلون بصحة أذان الصبي المميز بالأثر والمعقول:

أما الأثر: فعن عبداله بن أبي بكر بن أنس بن مالك رضي الله عنهم قال:

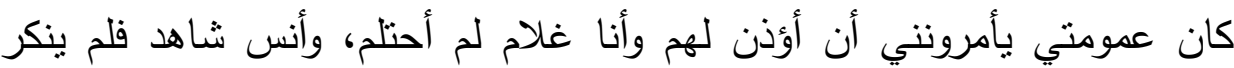
ذلك (؟)

قال صاحبا المغني والثرح: وهذا مما يظهر ولا يخفى، فيكون إجماعاًا(V)،

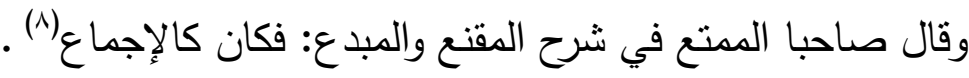

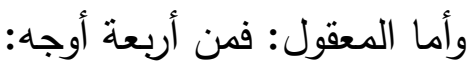

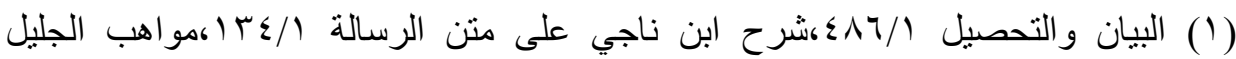
$\varepsilon r 0 / 1$

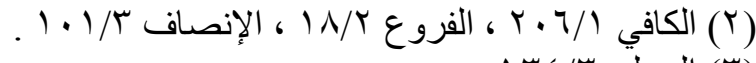

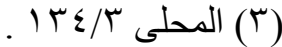

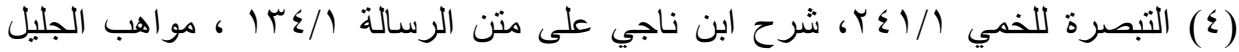
$\leqslant$ ro/1

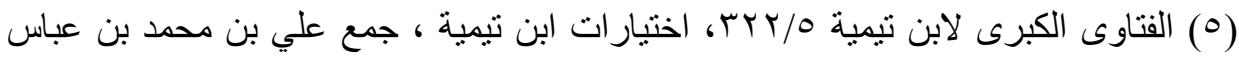

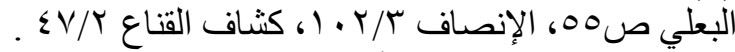

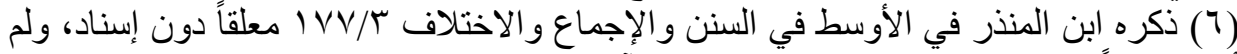

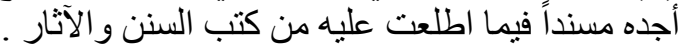

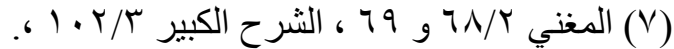

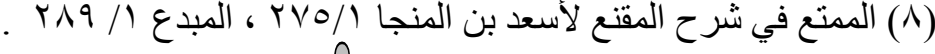




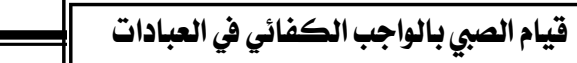

1 - أن الصبي المميز إذا أذن وأقام فقد حصل المقصود بأذانه، وهو

الإعلام، فيقع صحيحاً مجزئًاً (1).

r - الأذان والإقامة ذكر وعبادة، والصبي الممبز من أهل الذكر والعبادة(؟).

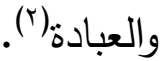

r - أن الأذان والإقامة شعار من شعائر الإسلام، وإذا أذن الصبي المميز

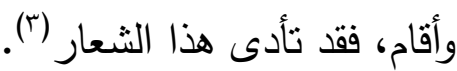

؟ - الصبي المميز ذكر تصح صلاته، فصح أذانه كالبالغ (\&).

أدلة القول الثاني: استدل القائلون بأن أذان الصبي المميز وإقامته لا يجزئ ولا يسقط به فرض الكفاية - عند من يقول: إنهما فرض كفاية - بالسنة والمعقول:

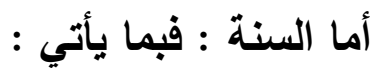

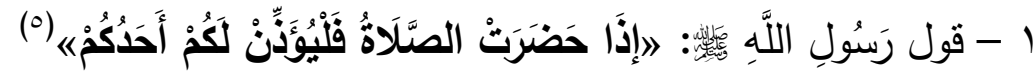

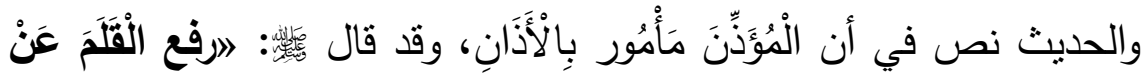

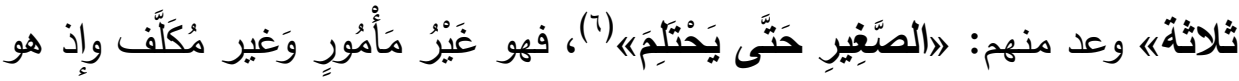

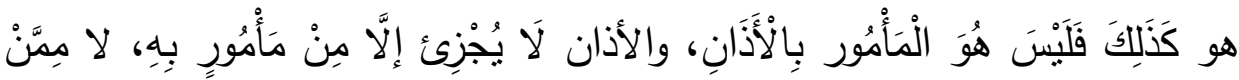

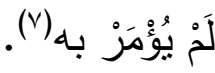

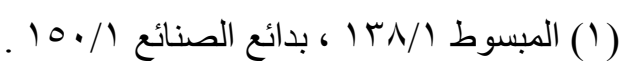

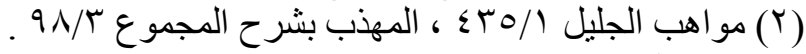

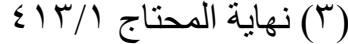

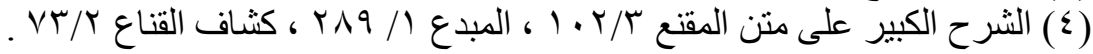

$$
\begin{aligned}
& \text { (0) سبق تخريجه (ص) (1)). }
\end{aligned}
$$

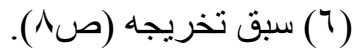

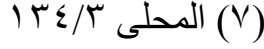




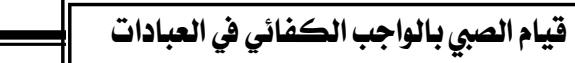

ويمكن أن يناقش هذا: بما سبق من أن الصبي وإن لم تجب عليه العبادات،

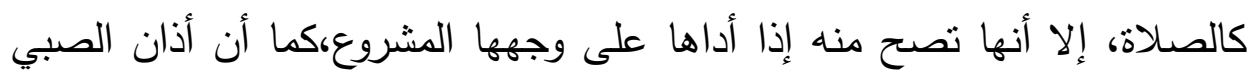

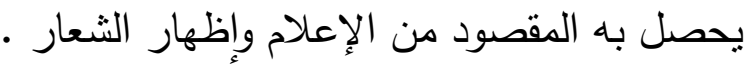

r - عن أبي هريرة رضي الله عنه قال: قال رسول الله

والمؤذن مؤتمن، اللهم أرشد الأئمة ، واغفر للمؤذنين"( ().

والحديث بدل على أن المؤذن مؤتمن؛ لأنه مُوَقَتٌُّ يعتد على إخباره بدخول

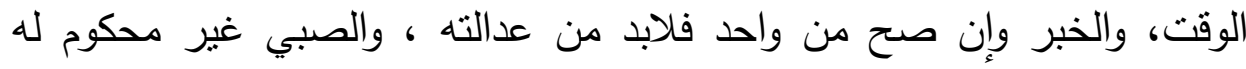

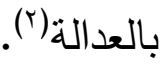

ويجاب عن هذا: بأن الصبي المميز يقبل خبره فيما طريقه المشاهدة، كما لو

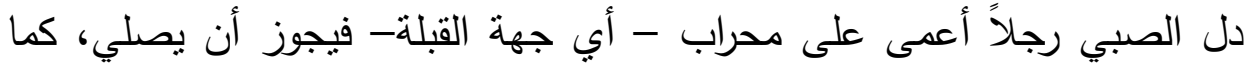

يقبل قوله في الإذن في دخول الدار وحمل الهدية (r).

وأما المعقول: فهو أن الأذان والإقامة فرض كفاية، وفعل الصبي يقع نفلاً،

والنفل لا يجزئ عن الفرض(ء).

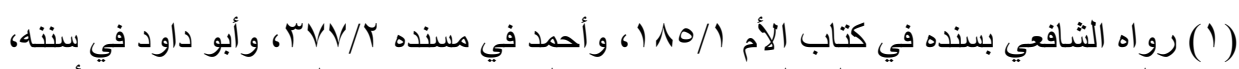

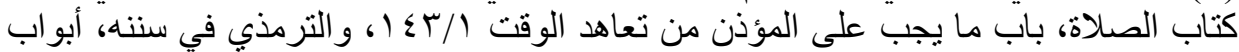

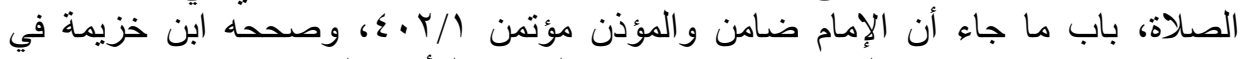

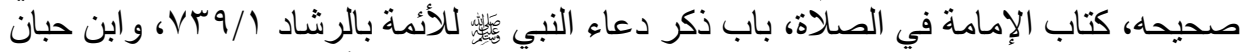

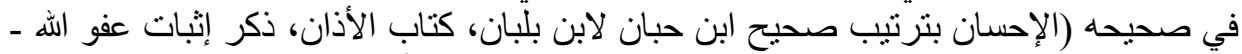

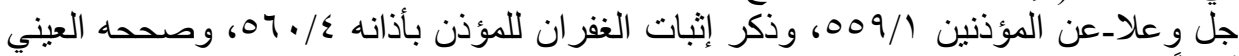

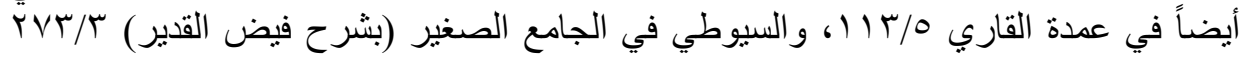
. r r

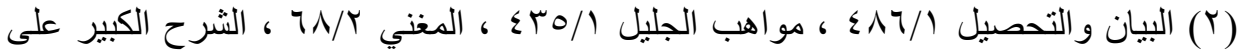

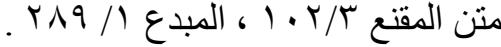

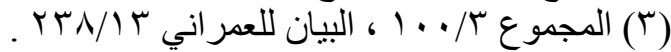

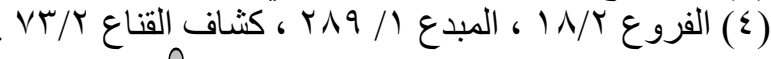




\section{قيام الصبي بالواجب الكفائي في العباداته}

ونوقش هذا: إن أذان الصبي وإقامته وإن لم يقعا فرضاً، بل يقعا نفلاً، إلا

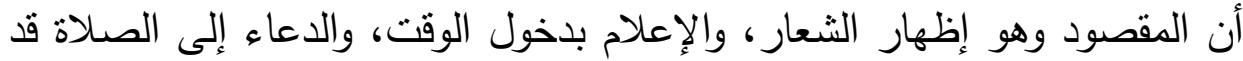
وقع، ووجد على وجهه، فسد مسد الفرض، فيكون مجزئاً مسقطاً فرض الكفاية (').

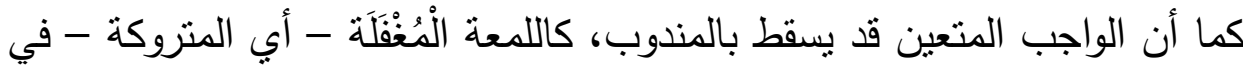

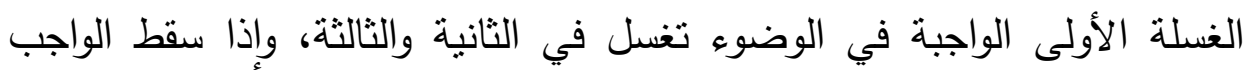

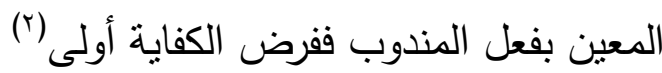

أدلة القول الثالث: استنل القائلون بصحة أذان الصبي الممبز إذا أذن تبعاً لبالغ ضبط للصبي الوقت، فإن المقصود من الأذان وهو الإعلام يقع على وجهه؛

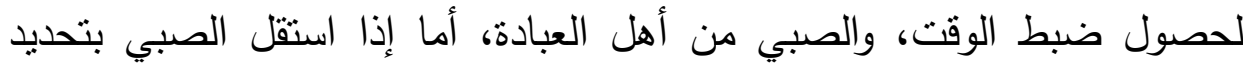
الوقت فيمكن وقوعه في الخطأ، فيلبس على الناس عبادتهم في الصوم والصلاة|("). القول الراجح: والراجح كواله أعلم- هو ما ذهب إليه أصحاب القول الأول

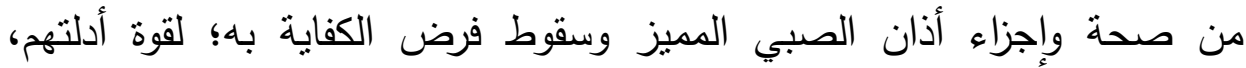
يضاف إلى ذلك أن المؤذن في العصر الحاضر لا يقوم بتحديد الوقت غالباً، فلا

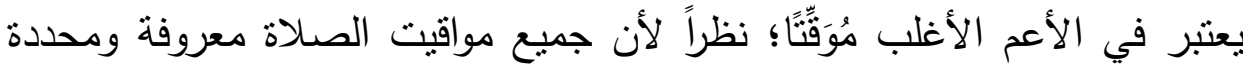

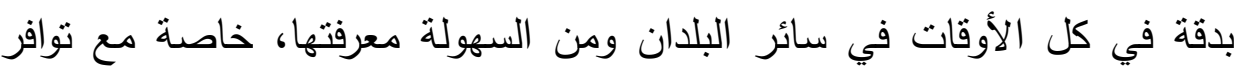
وسائل الاتصالات الحديثة، ومع وجود (التقاويم) في غالبية المساجد. فإذا أذن لنان الصبي المميز بناء على ذللك فإن المقصود بأذانه وإقامته -وهو الإعلام والدعاء

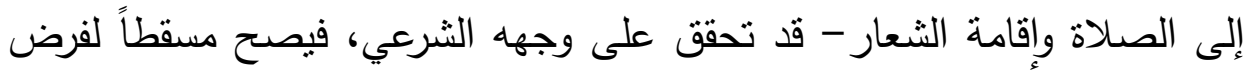

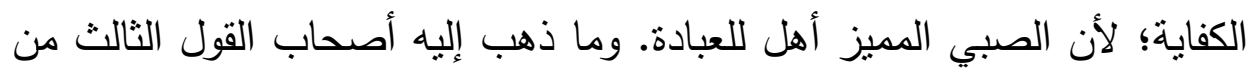

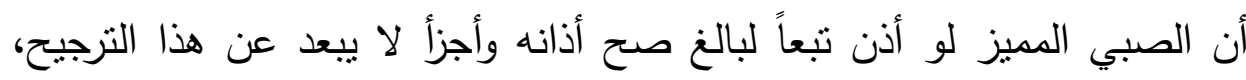

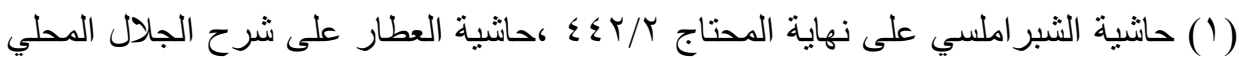

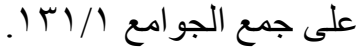

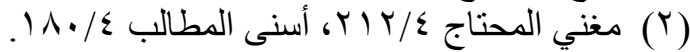

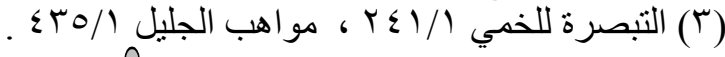

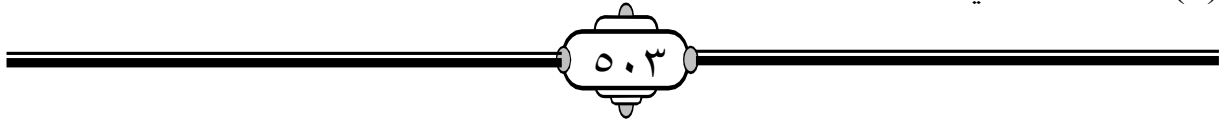




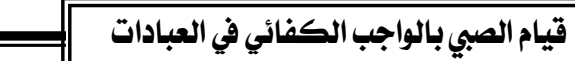

والاختلاف فقط بينهما في وسيلة ضبط الوقت، فهم يقولون: لو أذن تبعاً لبالغ

صح، بل قال صاحب مواهب الجليل: قول اللخمي: يصح أذان الصبي المميز إذا كان ضابطاً للوقت وأذن تبعاً لبالغ، لا ينبغي أن يختلف فيه (')، يعني عند المالكية.

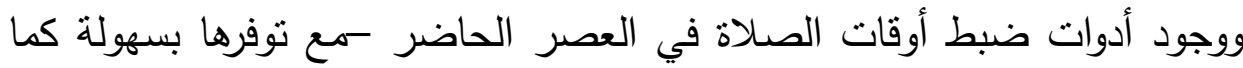

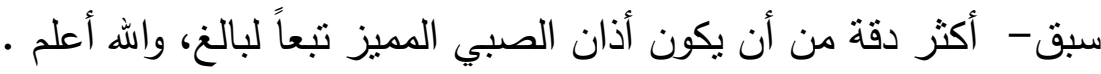
المطلب الثاني: حكم انعقاد صلاة الجماعة بالصبي أبين في هذا المطلب حكم صلاة الجماعة بإيجاز مناسب، ثم أذكر الحكم: لو قلنا:إنها فرض كفاية، هل تتعقد بالصبي، وهل يجوز أن يؤم فيها، ويسقط بذلك فرض الكفاية أم لا؟ وذللك في الفروع الثلاثة الآتية:

\section{الفرع الأول: حكم صلاة الجماعة}

اتفق الفقهاء على مشروعية صلاة الجماعة للصلوات الخمس المفروضة، وأن أداءها من أوكد العبادات وأجل الطاعات وأعظم شعائر الإسلام، وفيها فَضْنُ

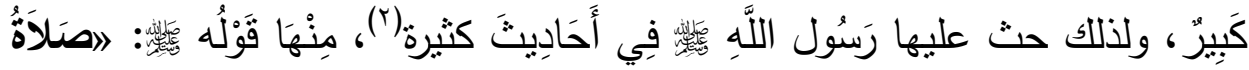

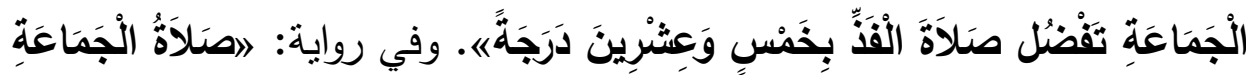

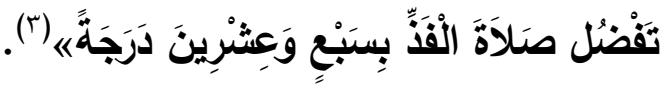
لكنهم اختلفوا في حكمها على أربعة أقوال، أذكرها وبعض أدلتها بإيجاز يناسب

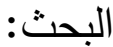

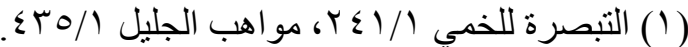

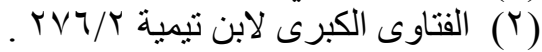

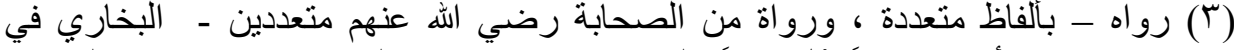

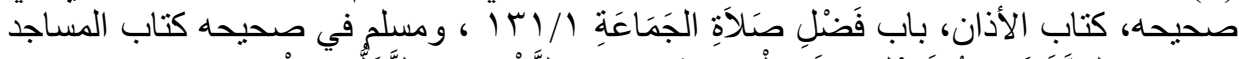

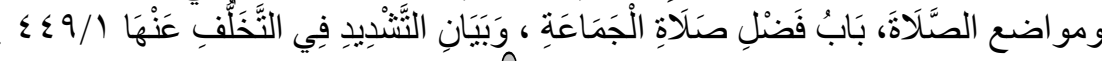




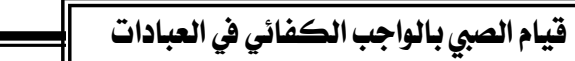

القول الأول: إن صلاة الجماعة فرض عين، وليست بشرط في صحة

الصلاة، وإليه ذهب الحنابلة في الصحيح من المذهب(') والحنفية في قول(ب) والثافعية في وجه(r)، وهو قول علي وعَبدالله بْنِ مَنْعُودٍ وَأَبِي مُوسَى الأشعري وابن

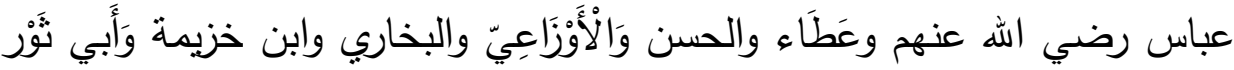
وابن المنذر -رحمهم الله(ء).

\section{واستدلوا على ذلك بأدلة كثيرة، منها:}

1

الآبية"(0).

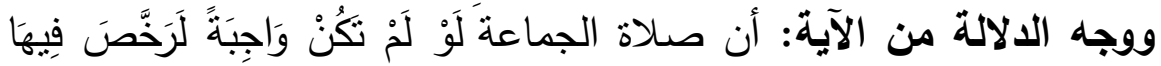

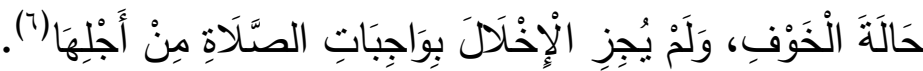

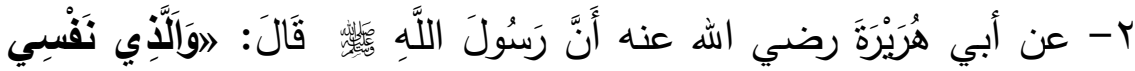

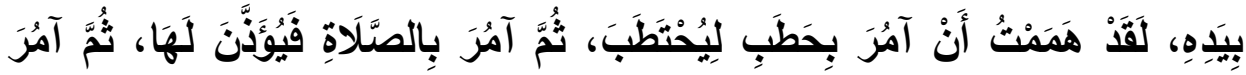

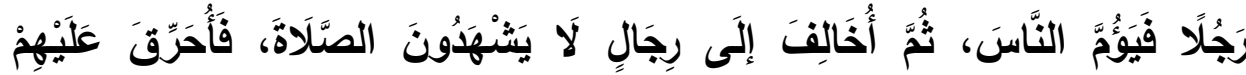

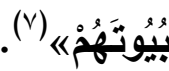

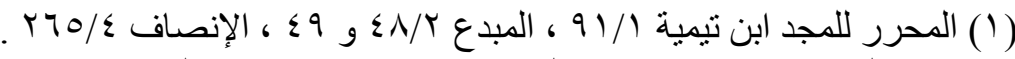

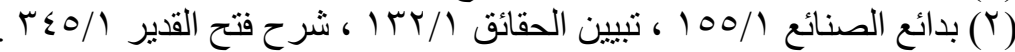

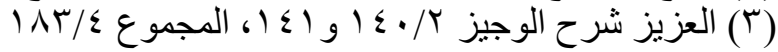

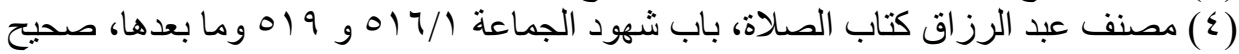

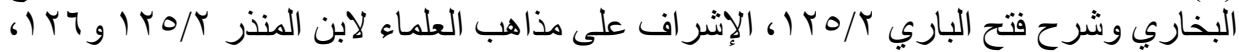

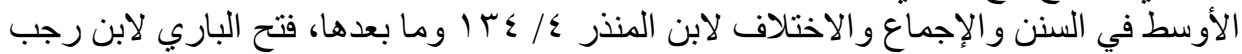

$$
\text { ( ) }
$$

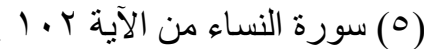

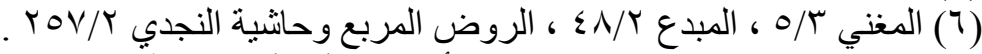

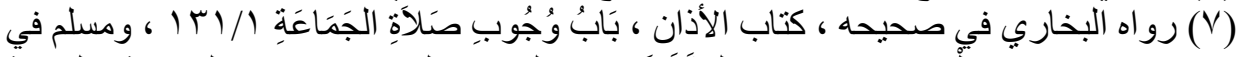

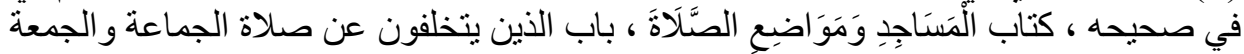

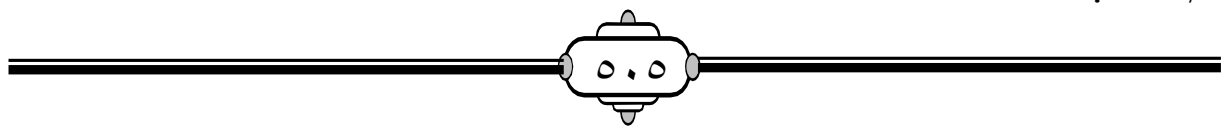




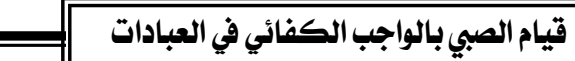

ووجه الدلالة من الحديث: وظََاهِر الحديث بدل على أن صلاة الجماعة

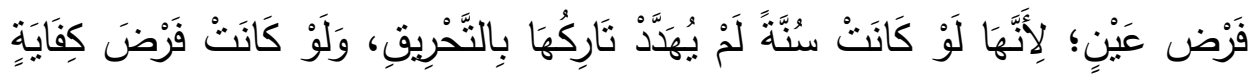

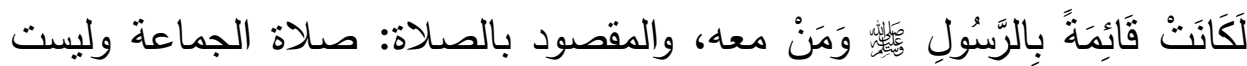

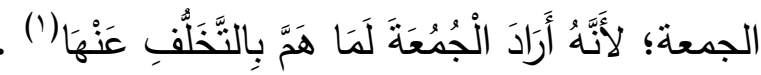

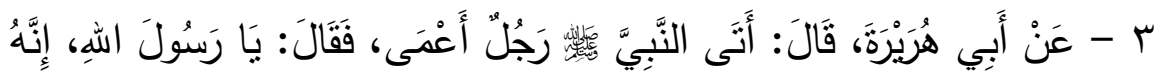

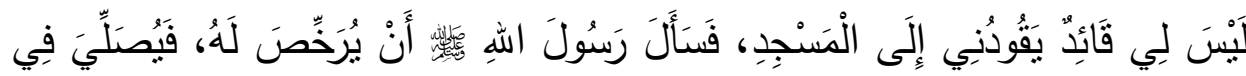

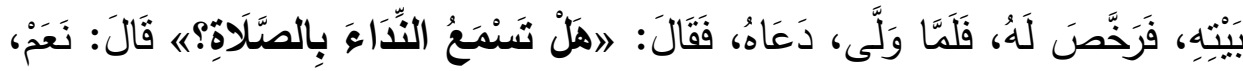

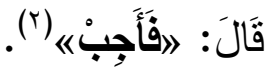

\section{وجه الدلالة من الحديث:}

أن النبِي ع - عَنْ عَبْدِاللهِ بن مسعود رضي الله عنه قَالَ: الهَنْ سَرَّهُ أَنْ يَلْقَى اللَّهَ غَدًا

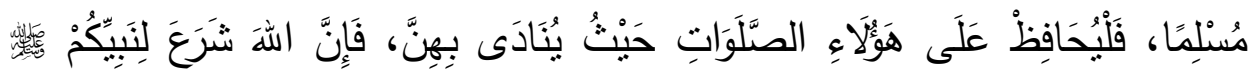

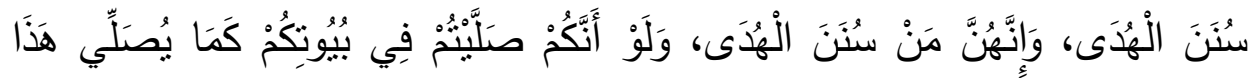

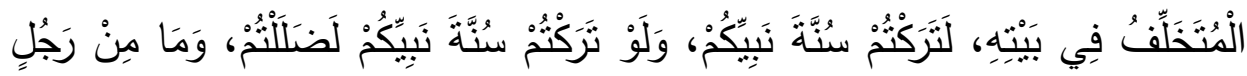

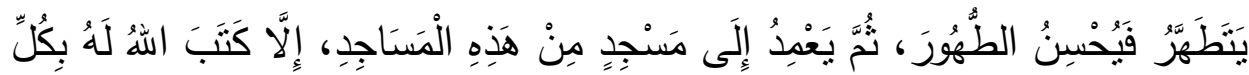

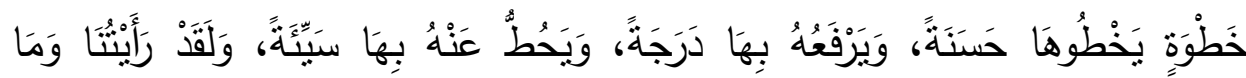
يَتَخَلَّفُْ

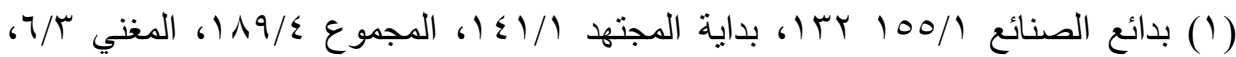

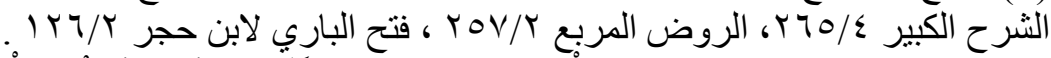

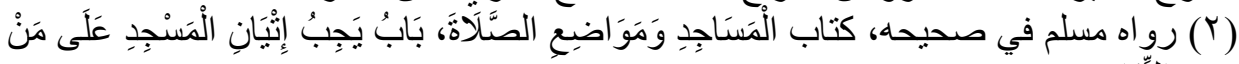

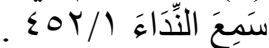

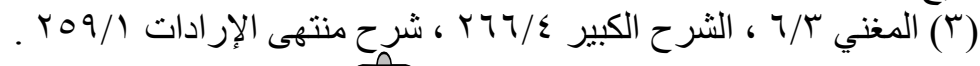




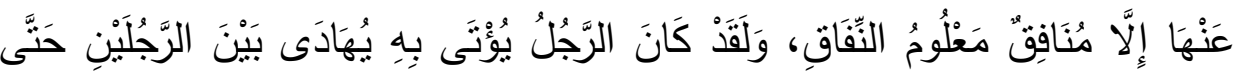

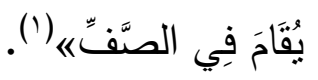
والأثر واضح الدلالة على وجوب صلاة الجماعة على الأعيان(؟). القول الثاني: إن صلاة الجماعة فرض كفاية، وإليه ذهب بعض الحنفية(r)، وبعض المالكية(؛) والثافعية في الأصح (0) وبعض الحنابلة(؟). واستدلوا بما يأتي: 1

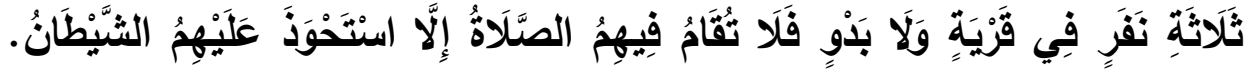

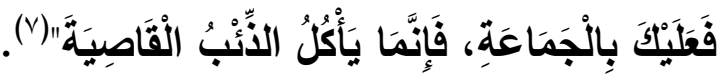
وجه الدلالة: في الحديث وعيد على ترك الجماعة، وهذا يدل على أنها

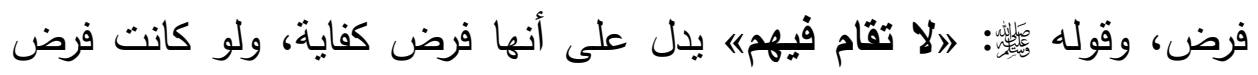
عين لقال: لا يقيمون (').

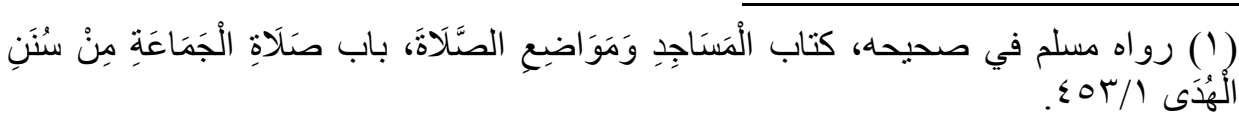

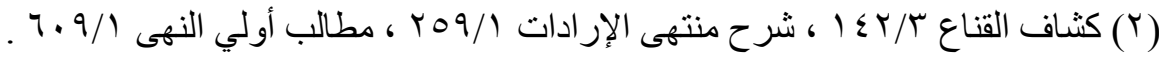

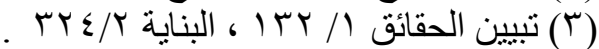

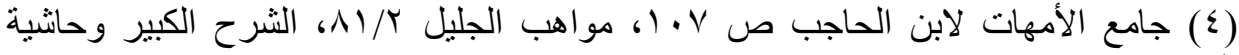

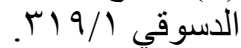

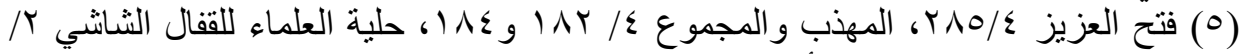

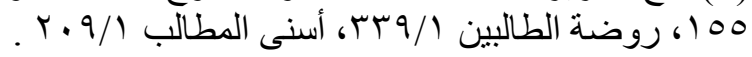

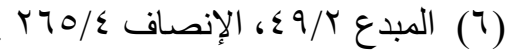

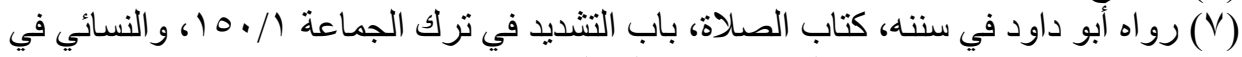

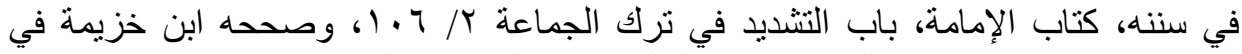

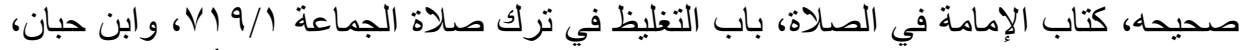

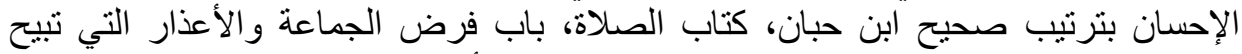

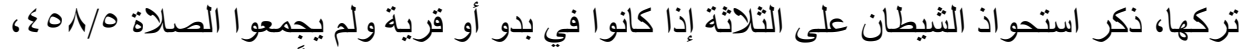

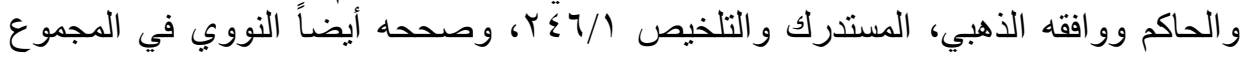

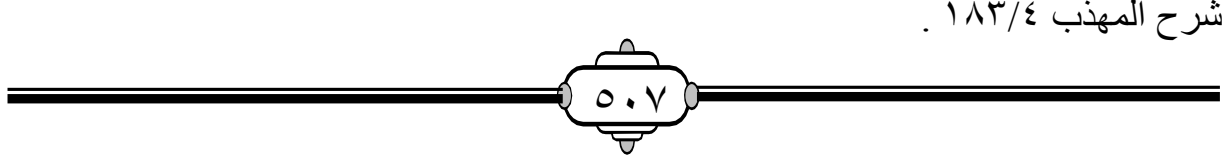




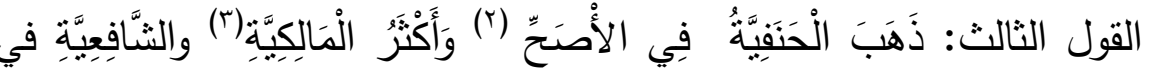

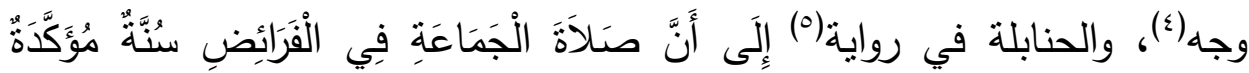

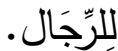
واستخلوا على ذلك بأدلة كثيرة، منها:

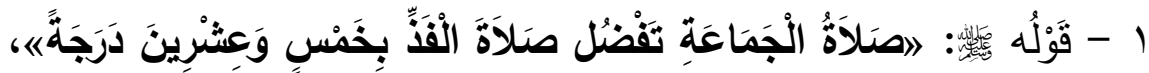

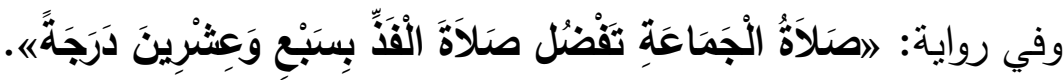
ووجه الدلالة منهما: أن التفاضل لا يكون إلا بين شيئين اشتركا في معنَى وتفاضلا فيه، وهذا يقتضي كون صلاة المنفرد فيها فضل يقصر عن صلاة الجماعة، وإذا ثبت أن فيها فضلًا ثبت إجزاؤها والاعتداد بهاب(؟).

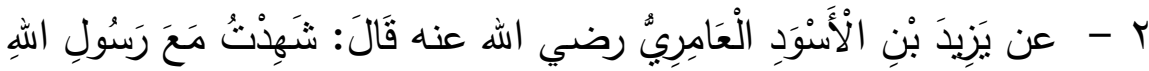

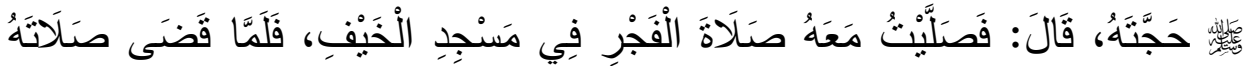

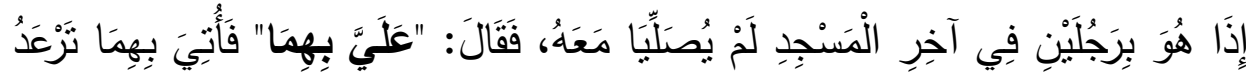

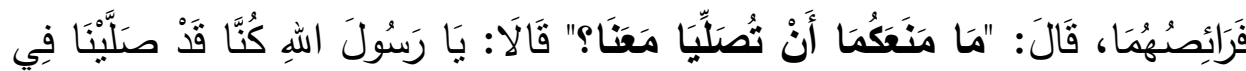

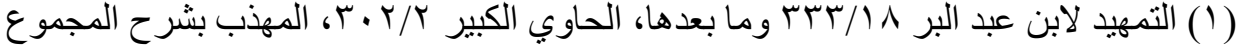

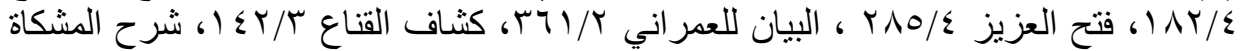

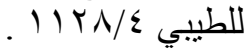

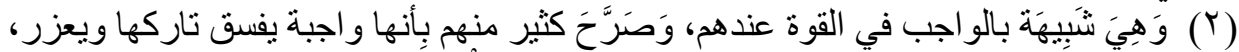

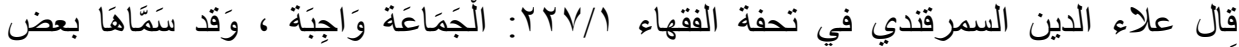

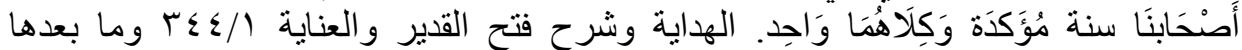

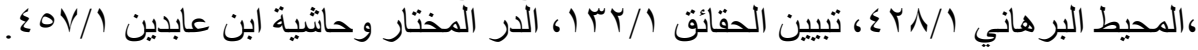

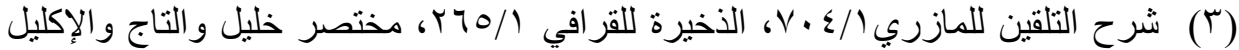

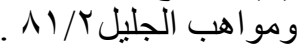

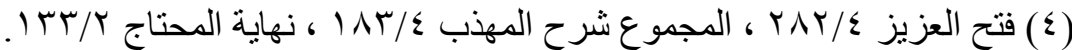

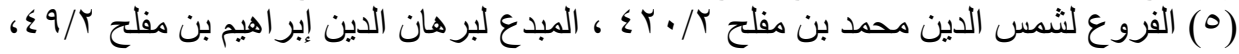

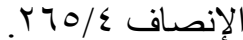

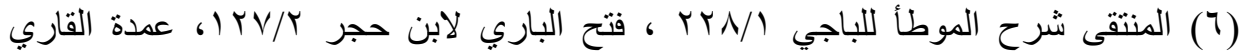

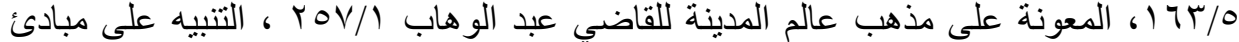

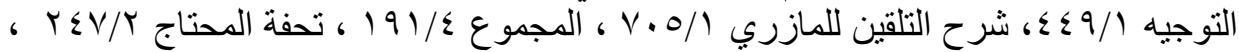

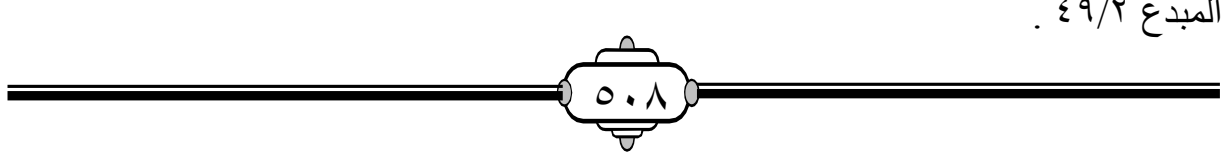




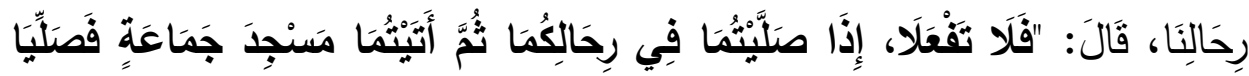

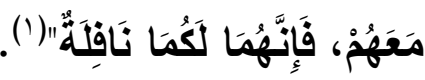

ووجه الالالة من الحديث: أن النبي

$$
\text { رحالهما، ولو كانت الجماعة واجبة لأنكر عليهما (؟) . }
$$

القول الرابع: إن صلاة الجماعة فرض عين في الصلوات الخمس، ولا تصح صلاة من صلى وحده دون عذر، فالجماعة شرط للصحة. وإليه ذهب الظاهرية(ץ) ، وأحمد في رواية عنه(๕)، اختارها بعض الحنابلة كابن عقيل وابن تيمية(0). واستدلوا على ذللك بأدلة، منها: عن ابن عباس رضي الله عنه قال: قال رسولُ الله

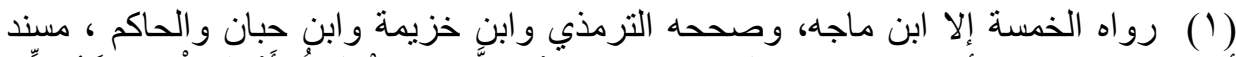

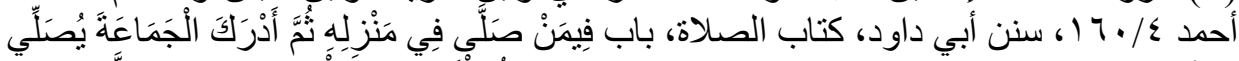

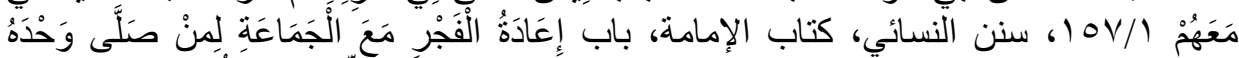

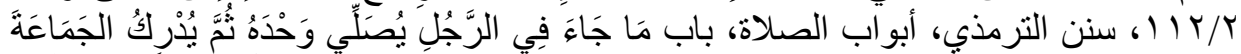

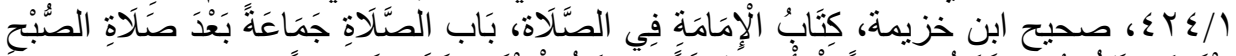

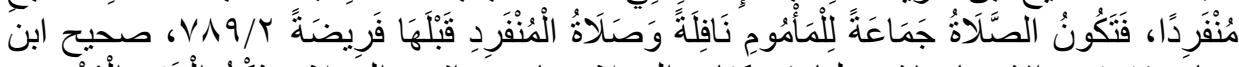

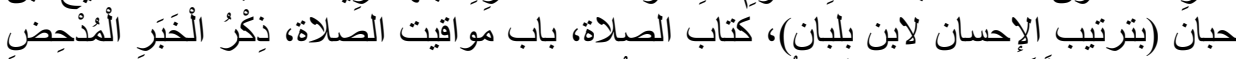

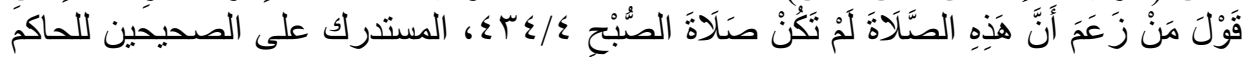
$r \leqslant \varepsilon / 1$

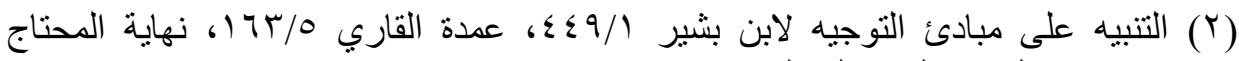

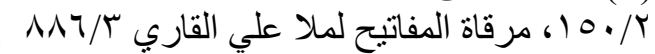

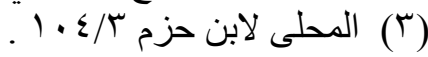

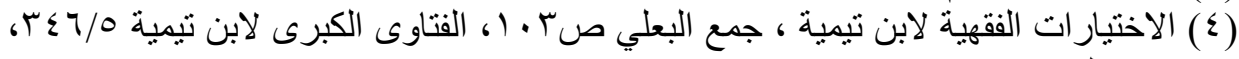

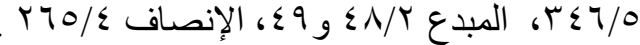

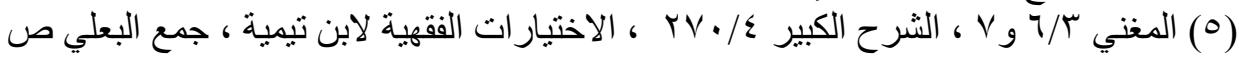

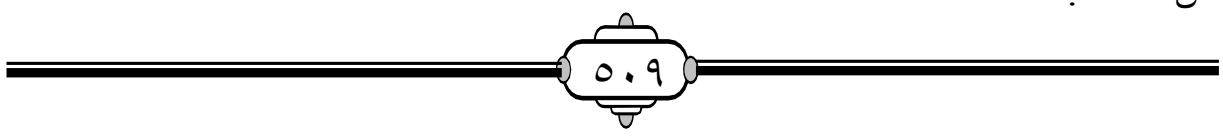




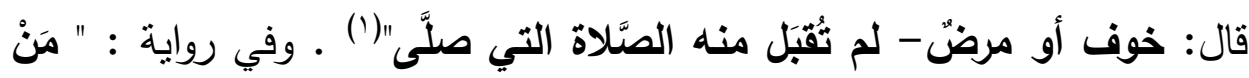

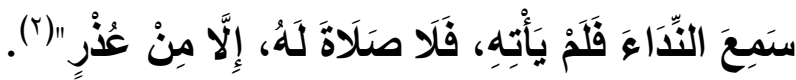
وفي الدسألة أدلة أخرى كثيرة لكل قول، ومناقثات وجوابات، لم أذكرها اختصاراً.

القول الراجح: والراجح - واله أعلم - هو القول بأن صلاة الجماعة فرض عين، ولكن الجماعة ليست شرطاً في صحة الصلاة؛ لظهور أدلته . ولكن لو قلنا بأنها فرض كفاية، كما هو قول الثنافعية في الأصح، وأقوال

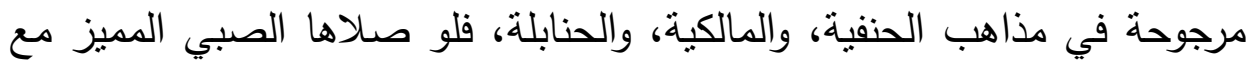
بالغ هل تتعقد به الجماعة، وهل يجوز أن يؤم البالغين فيها؟. هذا ما أفصله فيما يأني: - nen

الفرع الثاني: هل تنعقد صلاة الجماعة بالصبي ويسقط بها فرض الكفاية؟

سبق -قريباً- ذكر أقوال الفقهاء في حكم صلاة الجماعة، وأن بعض فقهاء

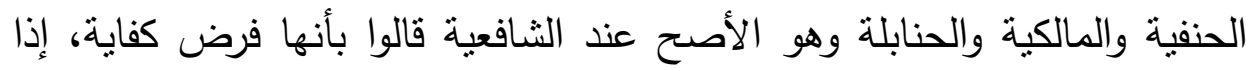

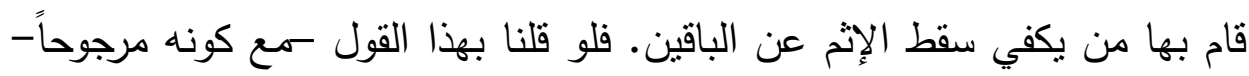
فهل تتعقد الجماعة بصبي مع رجل بالغ، ويكفي هذا في سقوط فرض الجماعة؟ الإن

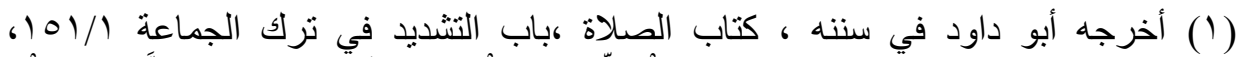

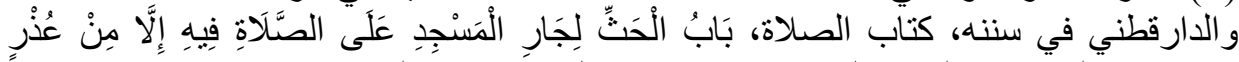

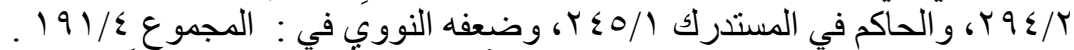

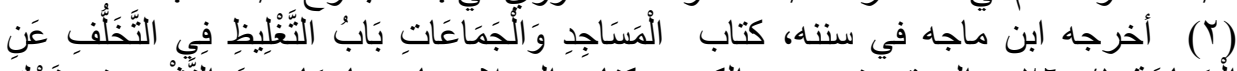

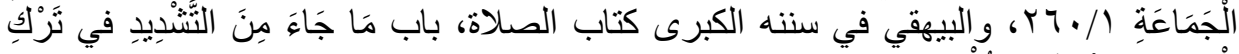

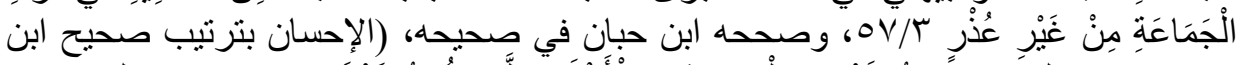

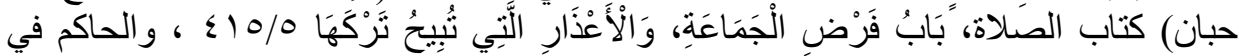

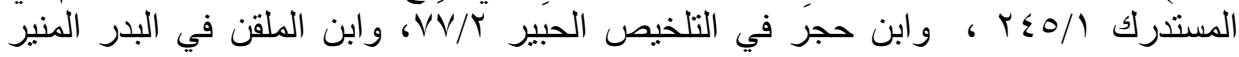

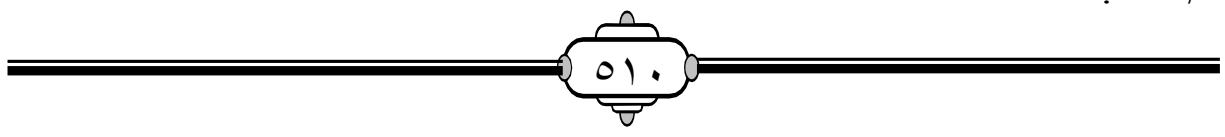


اتفق الفقهاء أن الجماعة لا تتعقد ببالغ واحد وصبي غير مديز؛ لأن صلاة غير

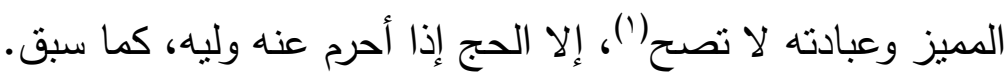
ثم اختلفوا في انعقادها برجل بالغ واحد مع صبي - واحد أو أكثر - على

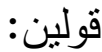

القول الأول: إن الجماعة لا تتعقد ببالغ وصبي - واحد أو أكثر - ولو كانوا

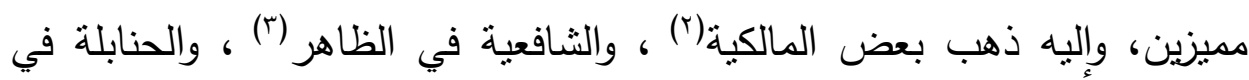
رواية(؟) معيزية

واستدلوا على ذلك بأن الصبي وإن كان مميزاً إلا أنه ليس من أهل الفرض،

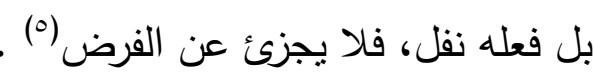

القول الثاني: إن الجماعة تتعقد ببالغ وصبي مميز، وإليه ذهب الحنفية(ا)

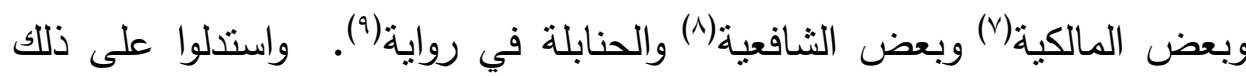
بالسنة والمعقول:

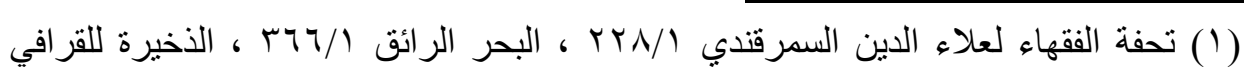

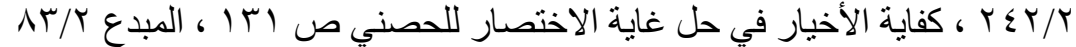

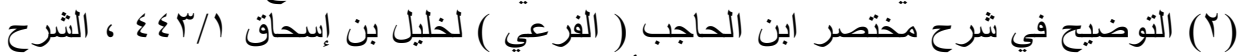

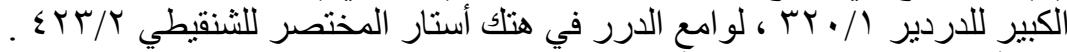

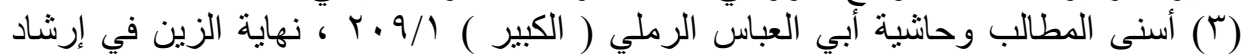

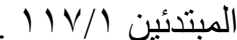

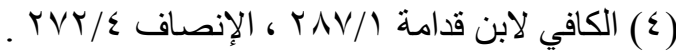

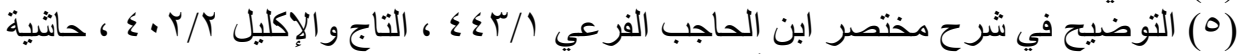

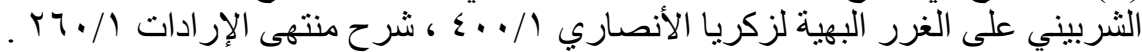

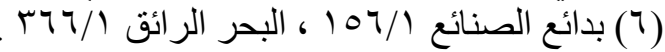

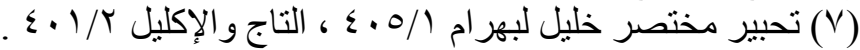

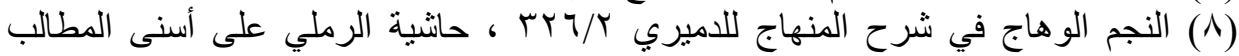
ะ $9 \wedge / 1$

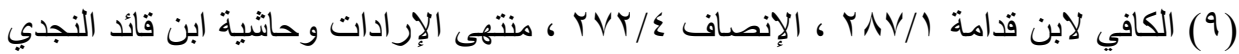

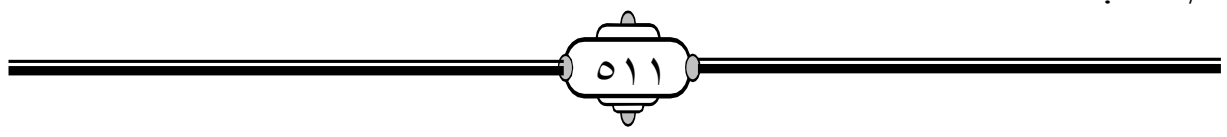


أما السنة: فقوله

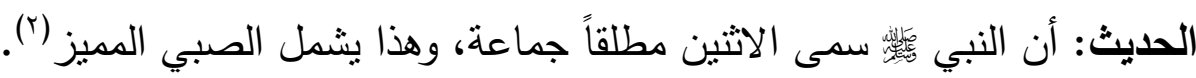

\section{وأما المعقول: فمن ثلاثة أوجه:}

1 - أن الجماعة معناها الاجنماع، فإذا انضم صبي مميز إلى إمام بالغ فقد

حصل الاجتماع وتصح الصلاة(r).

r - أن الصبي المميز من أهل الصلاة والعبادة ، فتتعقد به الجماعة(؛).

r- صلاة الصبي المميز وإن وقعت نافلة، إلا أنه تتعقد به الجماعة، كما لو

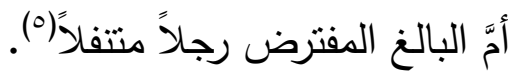

القول الراجح: والراجح - واله أعلم- أن صلاة الجماعة لو أداها رجل بالغ

مع صبي واحد أو أكثر فإن فرض الكفاية لا بسقط بها؛ بل لابد من فعل طائفة ذكور بالغين يظهر بهم الثعار. وقد ذكر الثافعية - وهم القائلون بأن صلاة

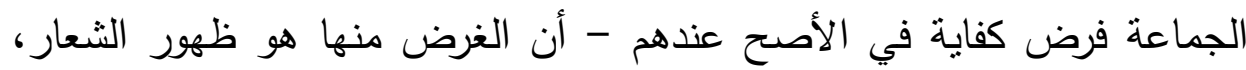

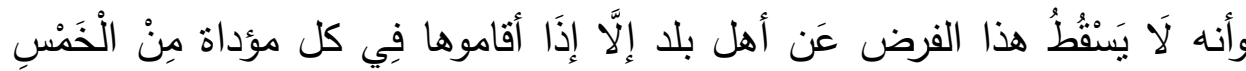

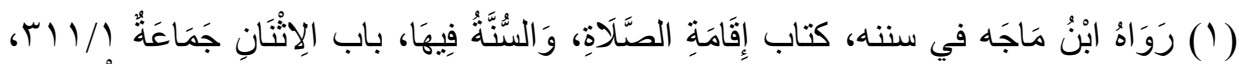

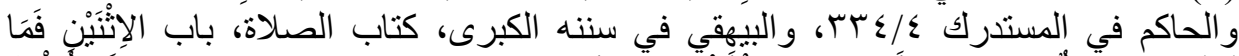

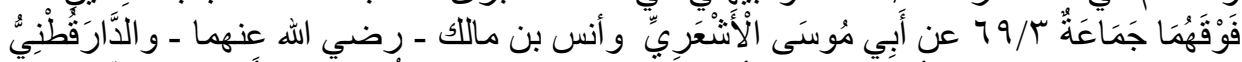

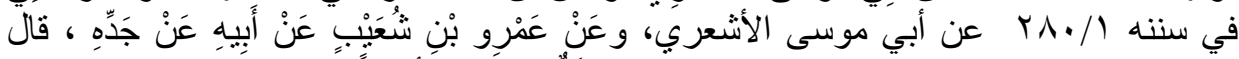

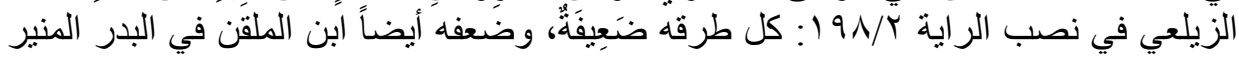

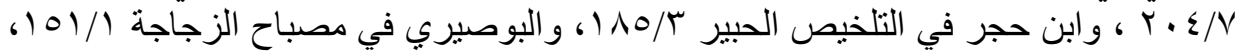

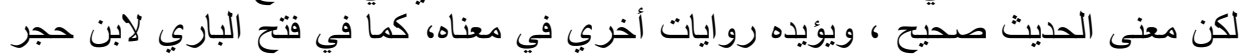

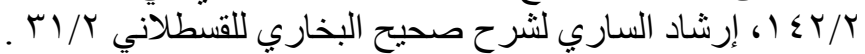

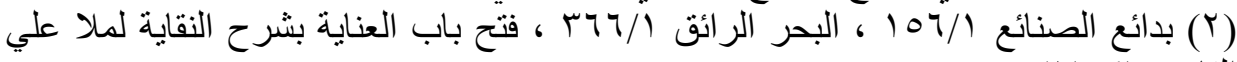

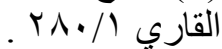

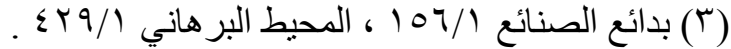

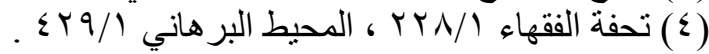

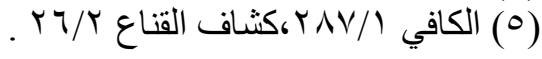

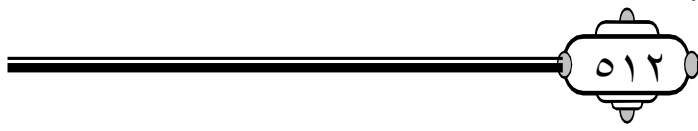




\section{قبيام الصبي بالواجب الكفائي في العباداته}

بِجَمَاعَةٍ ذُكُورِ أَحْرَارِ بَالِغِينَ، فتثقام الجماعة في البلدة الكبيرة في مواضحَ بحيث

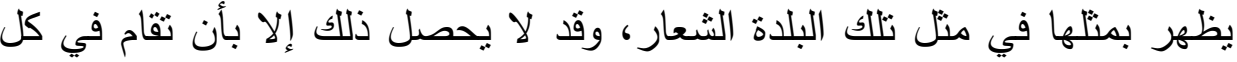

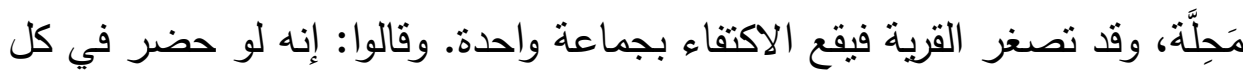
مسجد اثنان أو ثلاثة، بحيث لا يبدون للمارين فلا يحصل ظهور الثعار بهذا؛ وذللك لأن كل واحد في نفسه لم يفرض عليه لأجل صلاته جماعة، وإنما الغرض لأل

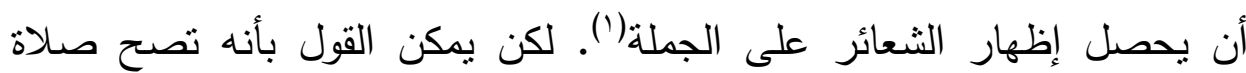
الجماعة ببالغ واحد وصبي واحد فأكثر في حالة ما إذا قلنا: إنها فرض عين، ويسقط الإثم عن البالغ؛ لأن الوجوب حينئذ باقٍ على كثير من الناس.

\section{الفرع الثالث: حكم إمامة الصبي في صلاة الجماعة}

اتفق العماء على أن إمامة الصبي غير المميز لا تصح؛ لأن عبادته غير

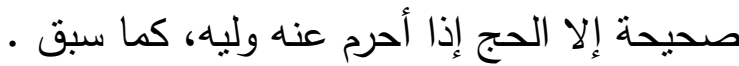
ثم اختلفوا: هل تصح إمامة الصبي المميز بالبالغين في صلاة الجماعة للصلوات الخمس المفروضة، ويسقط بذلك فرض الكفاية، لو قلنا:إن صلاة

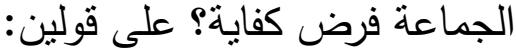

القول الأول: عدم الصحة، وإليه ذهب الحنفية(؟)، والمالكية في المعتمد(؟)،

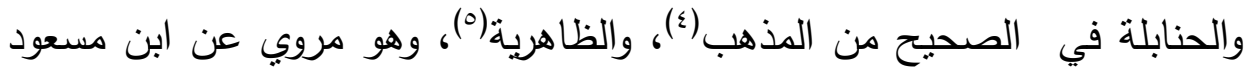
وابن عباس رضي الله عنهم •

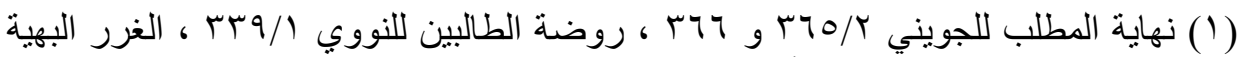

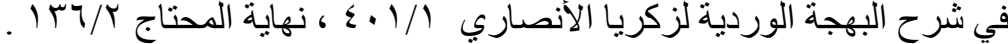

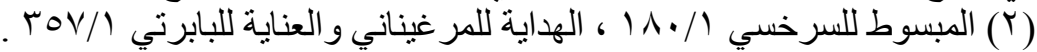

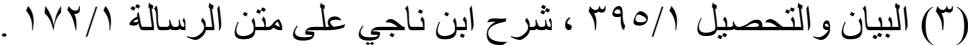

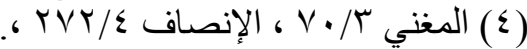

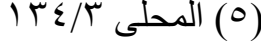




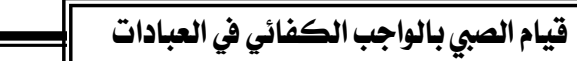

وهو قول عمر بن عبد العزيز وعطاء ومجاهد والثعبي والثوري

$$
\text { والأوزاعي (') }
$$

القول الثاني: تصح إمامة الصبي الميز للبالغين في صداة الفرض، وإليه

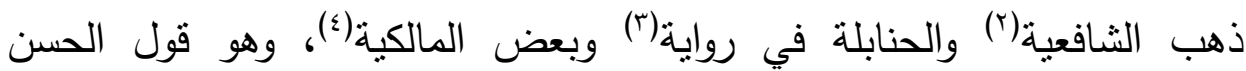
البصري وإسحاق بن راهويه وأبي ثور وابن المنذر (॰). ورجح هذا القول بدر الدين العيني من الحنفية(؟). الأدلة: أولاً: أدلة القول الأول: استدل القائلون بعدم صحة إمامة الصبي المميز بالبالغين في صلاة الفرض بالسنة والأثر والمعقول: أما السنة : فالأحاديث الآتية : 1 ضامنه (v) ومعنى الحديث: أن صلاة الإمام تتضمن صلاة المأموم صحة وفساداً، ولا شك أن الثيء يتضمن ما دونه، لا ما فوقه، وصلاة الصبي نفل؛ لكونه غير

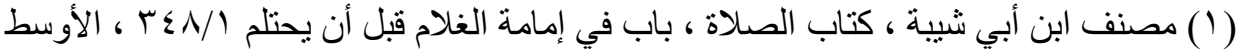

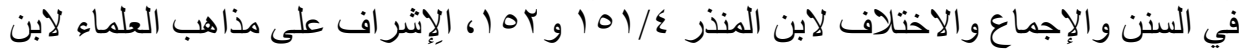

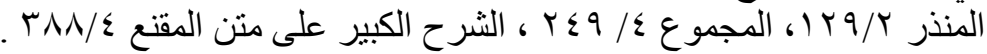

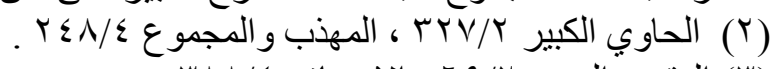

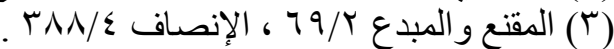

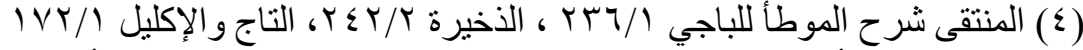

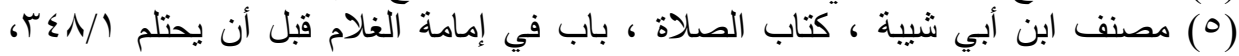

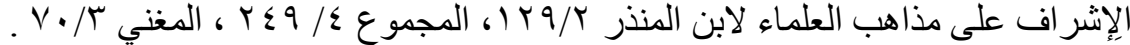

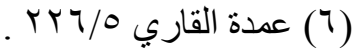

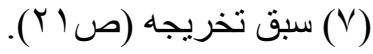


مكلف، وصلاة المأموم فرض، فيتعذر التضمن، فلم يصح اقتداء البالغ بالصبي ('). ونوقش هذا: بأن الصبي المميز من أهل القربة والعبادة، ونيته صحيحة شرعاً - كما سبق -فإذا كان في صلاة ظهر أو عصر - منثلاً فهو مُصَلِّ للظهر والعصر، فإذا اقتدى به بالغ فهما في صلاة واحدة ، فيصح الاقتداء به(؟).

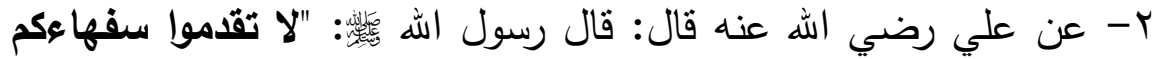

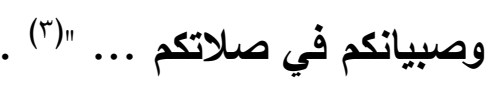

والحديث فيه النهي عن تقديم الصبيان في الصلاة ، ومنعهم من أن يكونوا

ونوقش هذا: بأن الحديث لا يصح بوجه من الوجوه، بل قال بعضهم: إنه

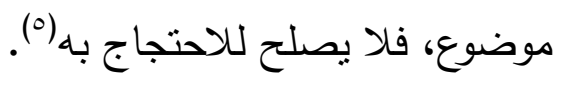

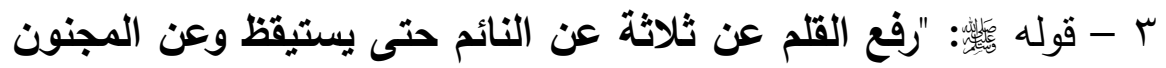
حتى يعقل وعن الصبي حتى يحتلم"(`) فالصبي مرفوع عنه القلم، فهو غير مخاطب ولا مكلف بالإمامة، فلا تجزئ ولا تصح منه" (') . .

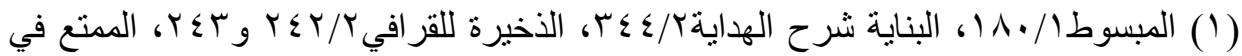

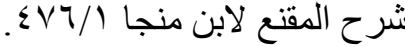

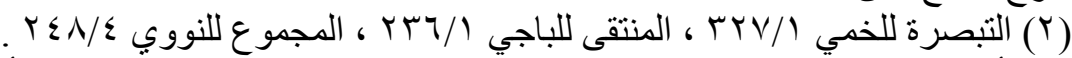

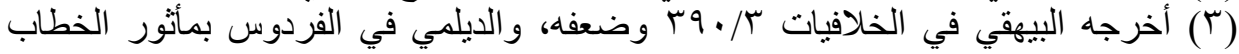

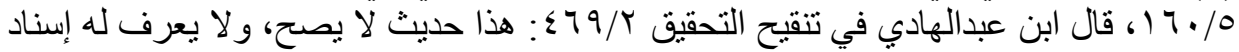

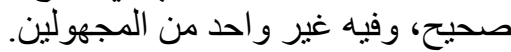

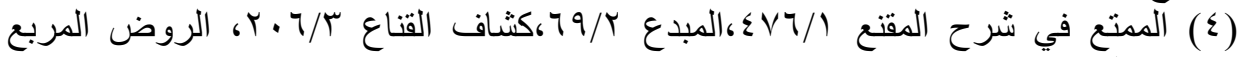

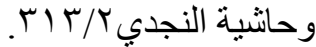

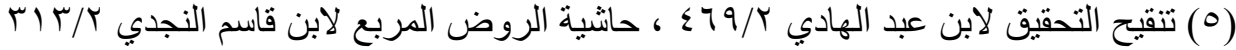

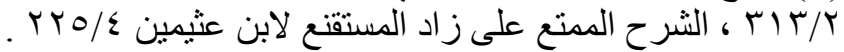

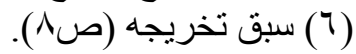

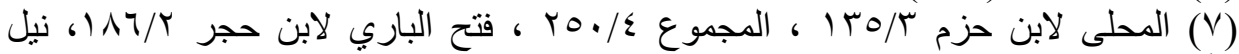
$=\underbrace{010}_{010}=$ 


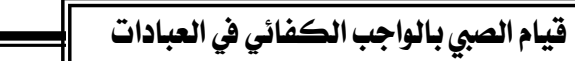

ونوقش هذا : بأن رفع القلم عن الصبي لا يستلزم عدم صحة صلاته وإمامته إذا كان مميزاً، بل صلاته صحيحة ما كانت مستوفية ومستجمعة للأركان والثروط، والتكليف ليس من شروط الصحة، والمراد برفع التكليف رفع الإيجاب، لا لانهان

$$
\begin{aligned}
& \text { نفي صحة الصلاة، وإذا صحت صلاته صحت إمامته|"( . } \\
& \text { وأما الأثر : فبما يأتي : }
\end{aligned}
$$

1 - عن ابن مسعود رضي الله عنه قال: "لا يؤم الغلام حتى تجب عليه

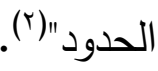

r - عن ابن عباس رضي اله عنه قال: "لا يؤم الغلام حتى يحتلم "(r) .

والأثران يدلان على عدم صحة إمامة الصبي قبل أن ييلغ، ولم ينقل عن

غيرهما من الصحابة خلاف لهما (ء).

\section{ونوقش هذا الاستتلال من وجهين :}

الأول : أن الأثرين ضعيفان كما ورد في تخريجهما، فلا يصلحان للاحتجاج

(1) الأوسط في السنن والإجماع والاختلاف لابن المنذر \&/OY م ، المجموع \&/0ب، نيل

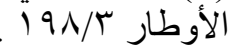

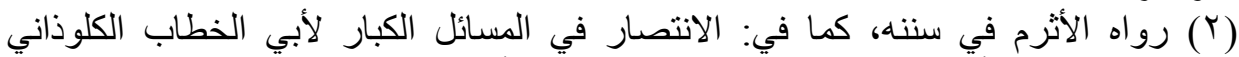

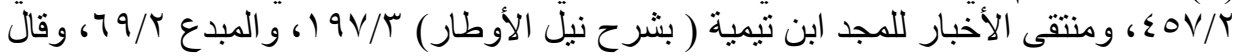

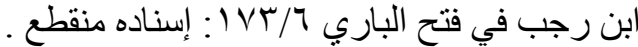

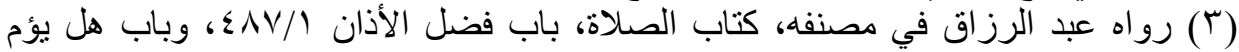

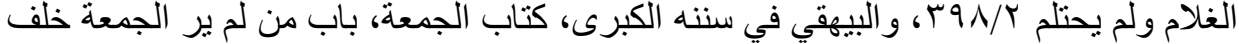

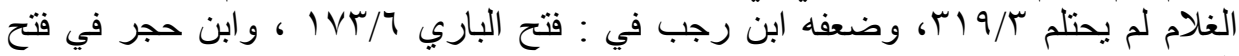

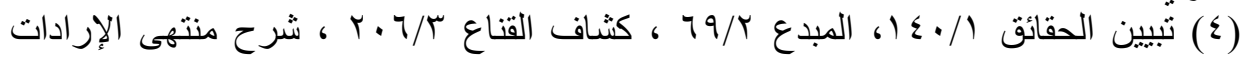

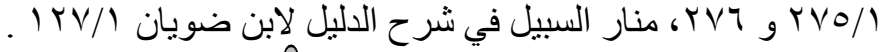




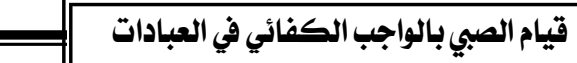

الثاني: أن القول: إنه لا يعرف لابن مسعود وابن عباس رضي الله عنهم

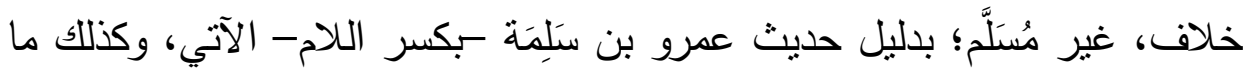

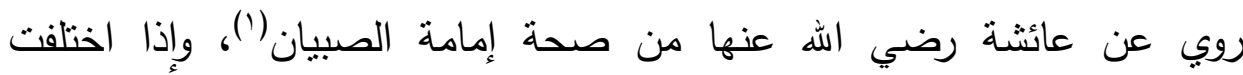

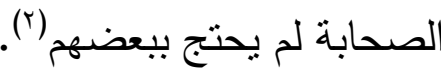

\section{وأما المعقول : فمن ثلاثة أوجه :}

الأول: إن الصبي لا يعتد به في عدد المؤتمين في الجمعة؛ لكونه غير

مكلف، فلا يجوز أن يكون إماماً، كالصبي الذي لا عقل له ، أو الدجنون (־). ونوقش هذا: بأن هناك فرقًا بين الصبي غير المميز والمجنون من ناحية، وبين الصبي المميز من ناحية أخرى؛ إذ غير المميز والمجنون لا تصح طهارتهما

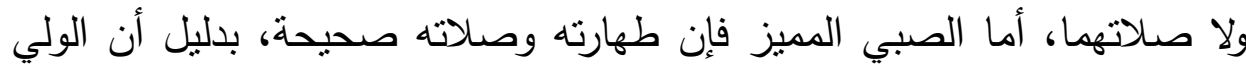

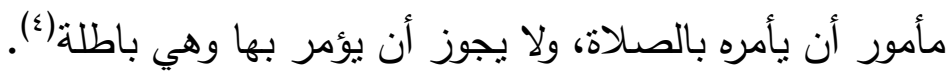

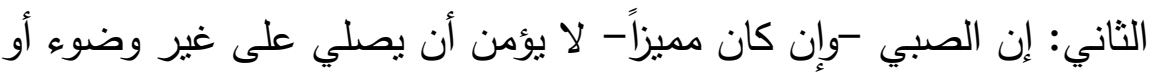
بغير نية، أو يخل بالقراءة في الصلاة السرية؛ إذ لا حرج عليه في ذلك؛ لكونه غير مكلف (ن)

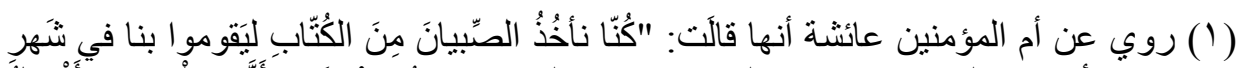

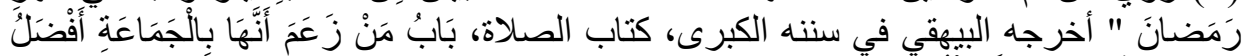

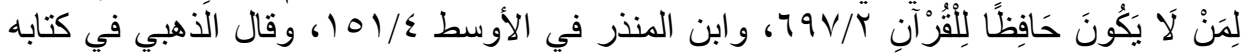

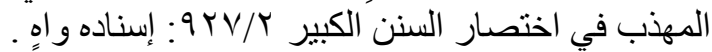

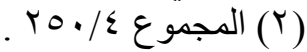

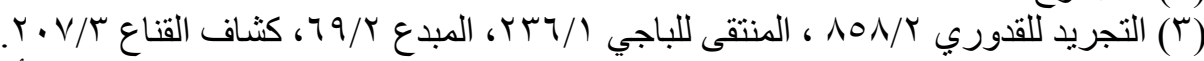

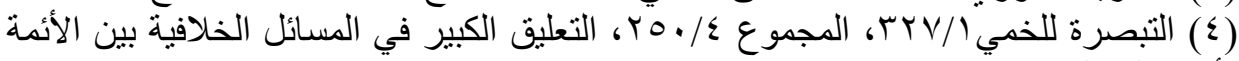

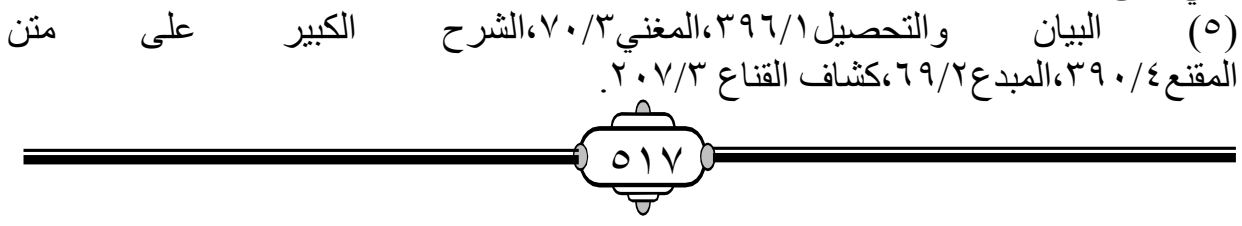

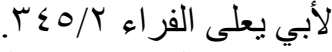




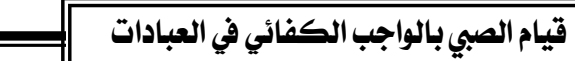

ونوقش هذا: بما سبق من أن صلاة الصبي المميز صحيحة ما كانت

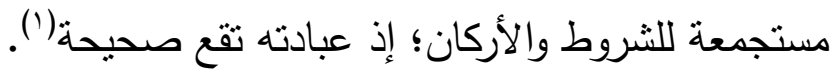

الثالث: إن الإمامة حال كمال، والصبي ليس من أهلها، كالمرأة بل آكد؛ لأن النقص فيه نقص يمنع التكليف، فلا يجوز أن يؤم الرجال كالمرأة(r). ويمكن أن يناقش هذا: بالفرق بين الصبي المميز والمرأة؛ إذ المرأة لا يصح

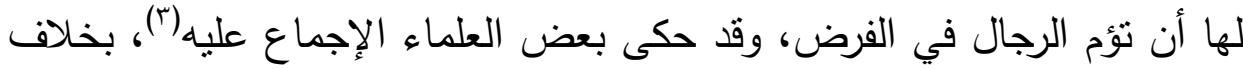

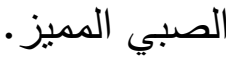

ثانياً: أدلة القول الثاني: استدل القائلون بصحة إمامة الصبي المميز بالبالغين في الصلوات المفروضة بالسنة والأثر والمعقول :

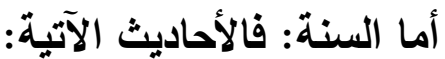

الحديث الأول: حديث عَمْرو بن سَلِمَة -بكسر اللامه الْجَرْمِيّ - بفتح الجيم

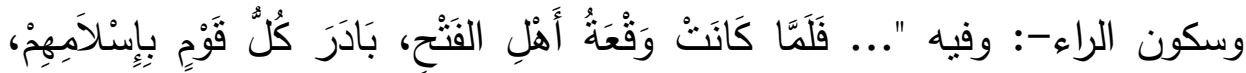

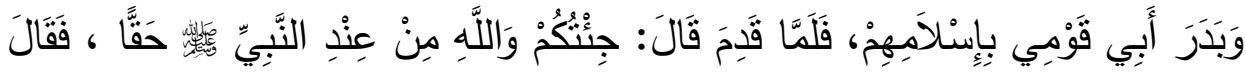

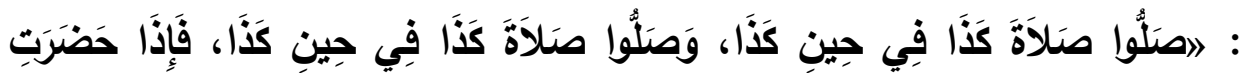

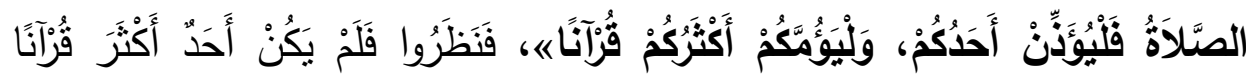

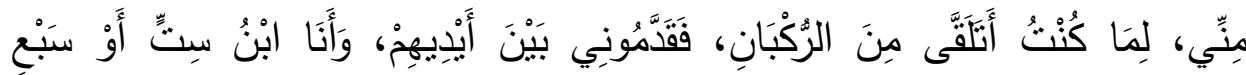

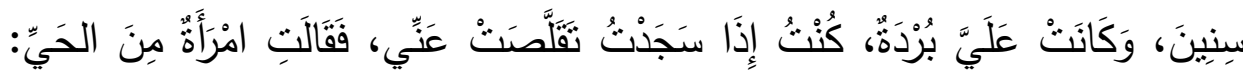

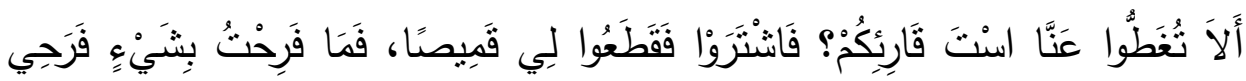

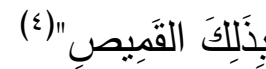

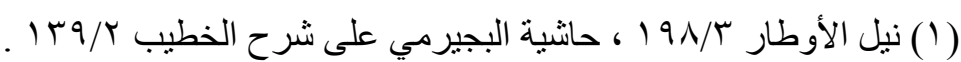

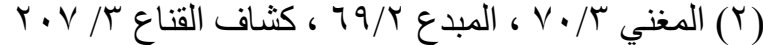

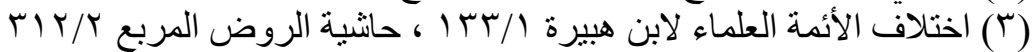

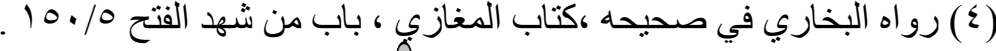




\section{والدلالة في الحديث من وجهين:}

الأول: أن عمرو بن سَلِمَة رضي الله عنه قد أمَّ قومه وهو صغير لم يبلغ

الحلم في عصر النتزيل، ولم يوجد له مخالف (1) .

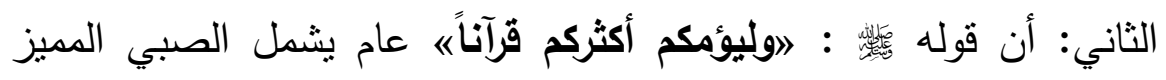

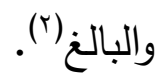

\section{ونوقش الاستدلال بالحديث بما يأتي:}

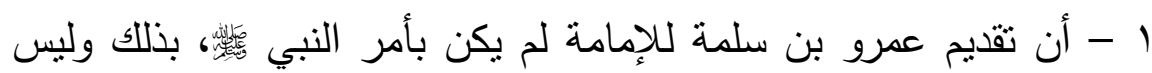

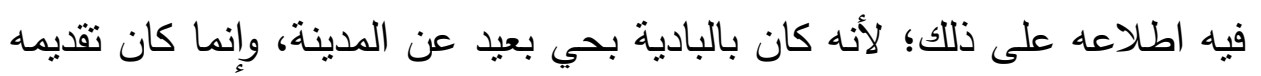

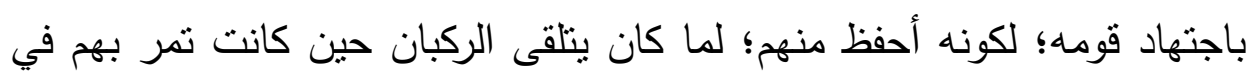

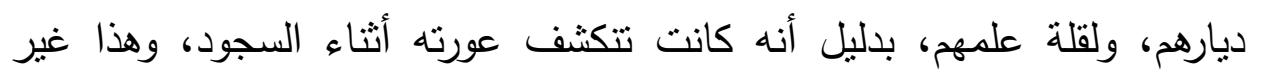

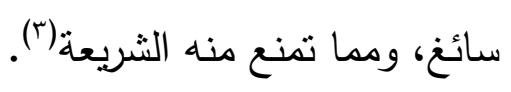

\section{وأجيب عن هذا:}

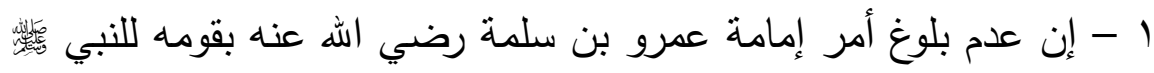

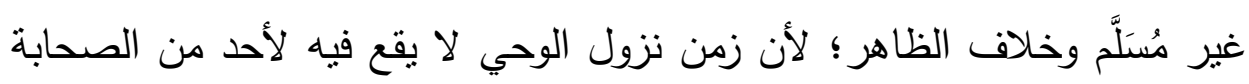

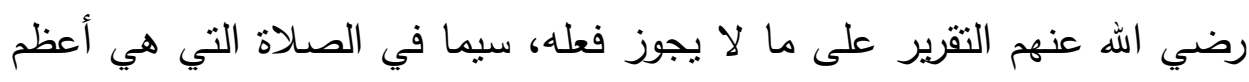

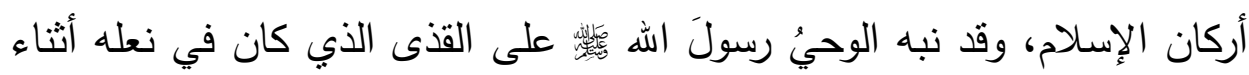

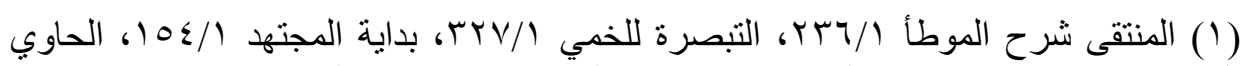

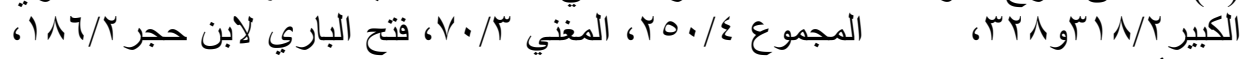

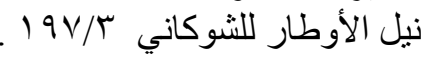

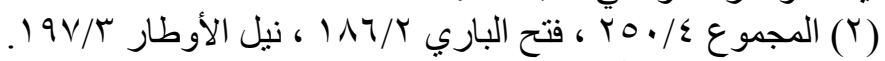

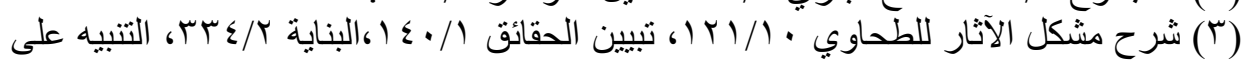

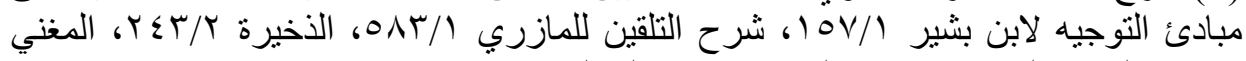

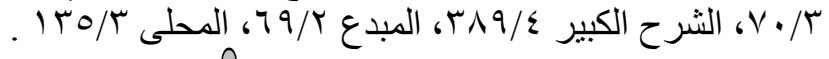


الصلاة(')، فلو كانت إمامة الصبي لا تصح لنزل الوحي، وأيضاً قد استدل جابر

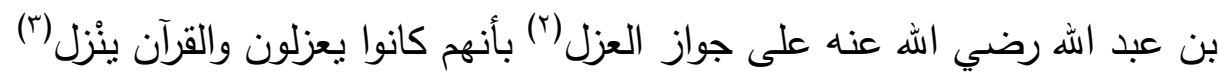

قال ابن عثيمين: لكن قد بعترضُ مُعترضُ فيقول: هل عَلِمَ بذلك - أي

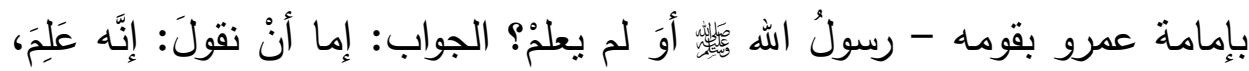

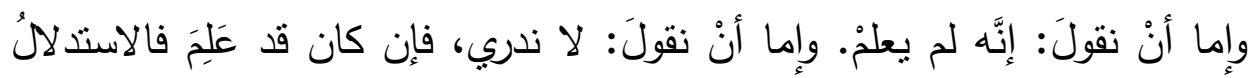

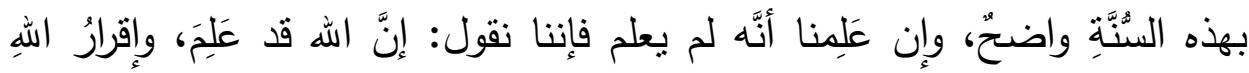
للشيء في زَمَنِ نزولِ الوحي دليلّ على جَوازِه، وأنه ليس بمنكرٍ لأنه لو كان منكراً

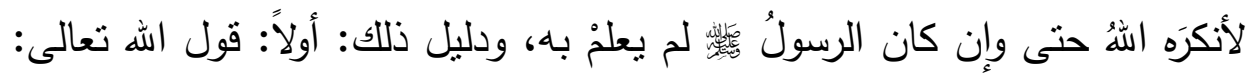

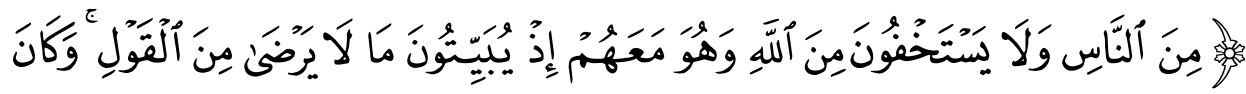

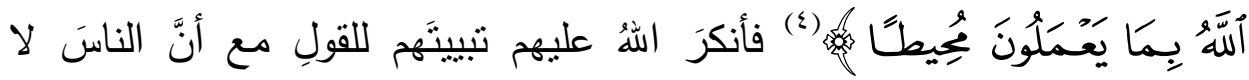

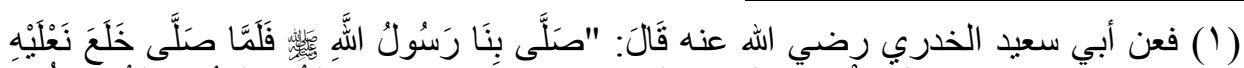

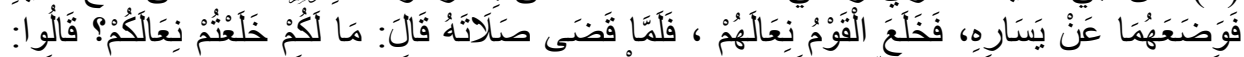

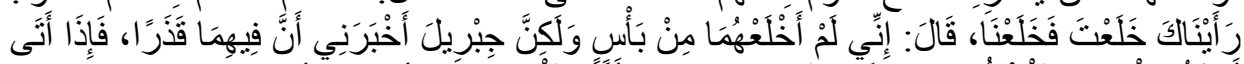

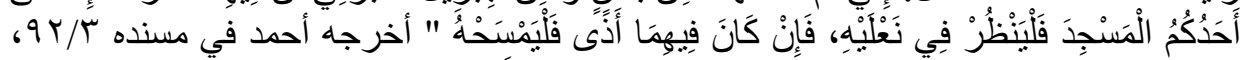

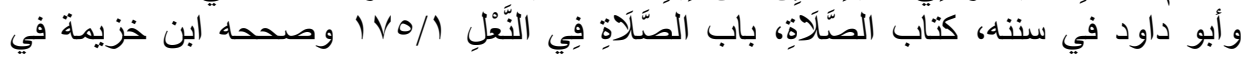

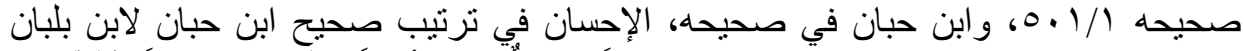

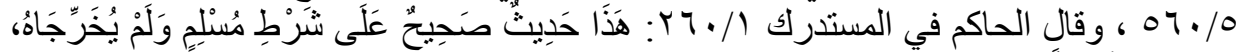

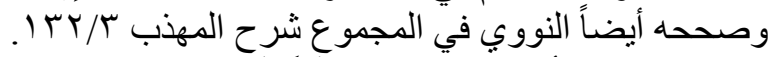

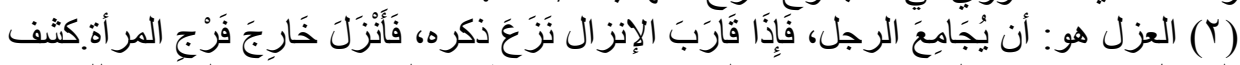

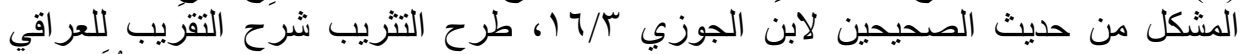

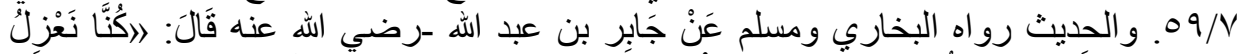

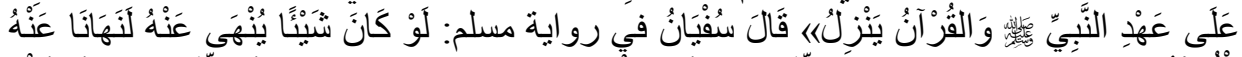

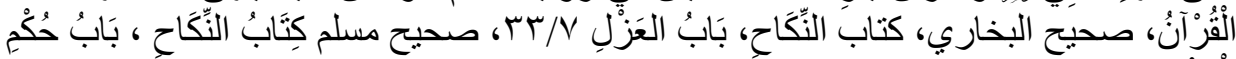

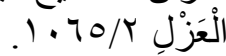

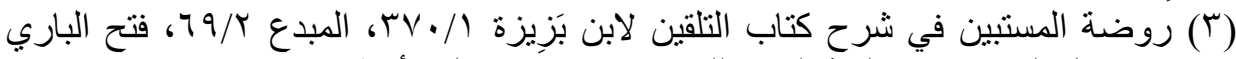

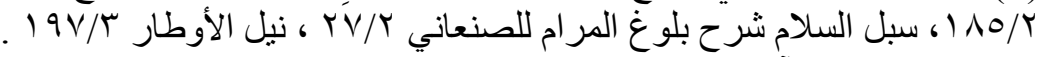

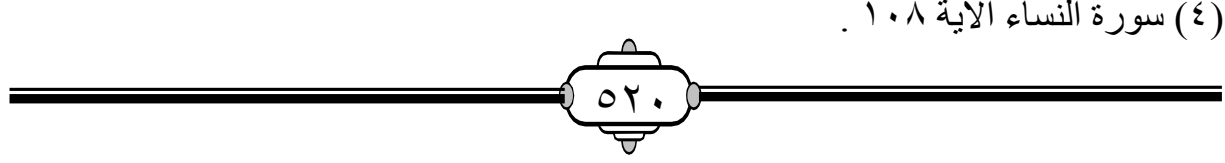




\section{قيام الصبي بالواجب الكفائي في العباداته}

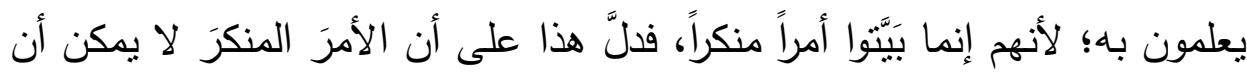

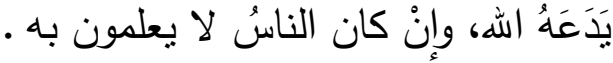

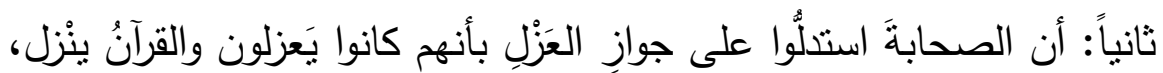

وهذا استخلالٌ منهم بإقرارِ اله تعالى (')

r - أن الذين قدموا عمرو بن سلمة كانوا صحابة، ولا يعرف لهم مخالف(r).

r - إن القدح في الحديث بأن فيه كثف العورة في الصلاة، وهو لا يجوز،

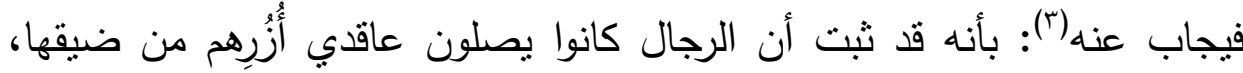

ويقال للنساء: لا ترفعن رؤوسكن حتى بستوي الرجال جلوساً (\&).

الحديث الثناني: عن أبي سعيد الخدري رضي الهَ عنه قَالَ: قَالَ رَسُولُ اللهِ

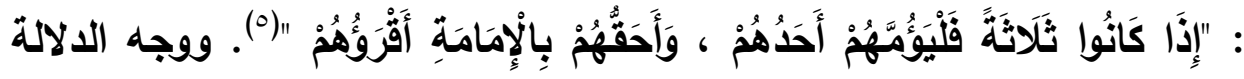

من الحديث: أن لفظ "أقرؤهم" عام، يثمل بعمومه البالغ والصبي المميز (†).

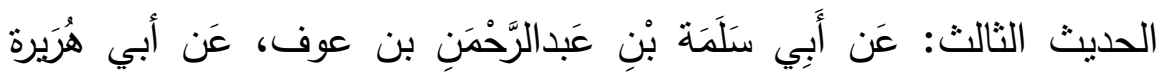

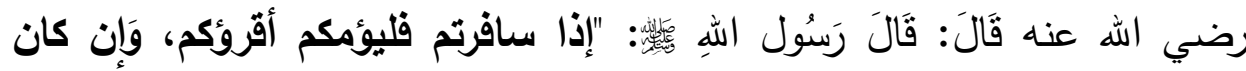

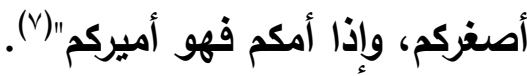

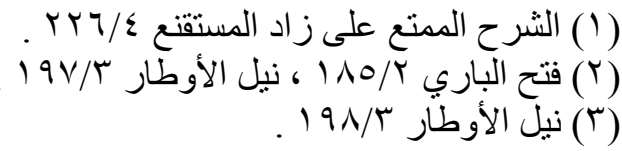

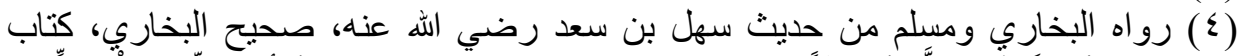

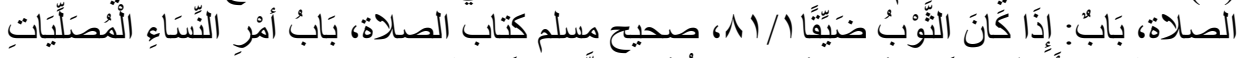

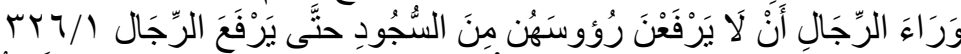

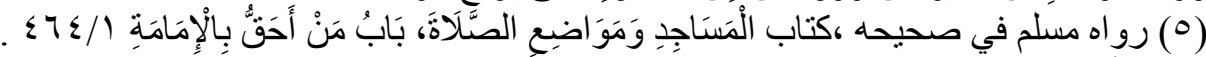

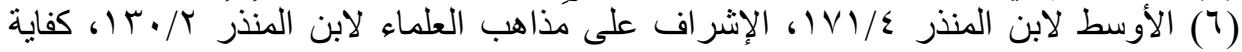

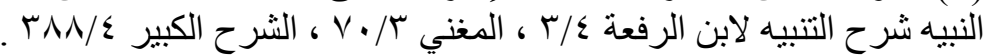

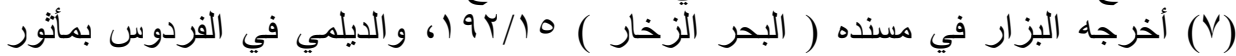

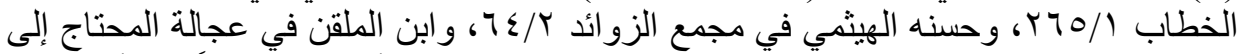

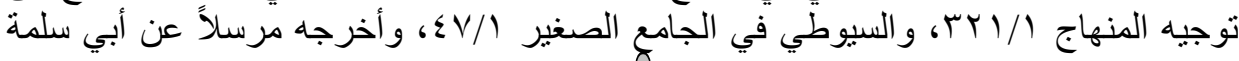




\section{ووجه الالالة من الحديث:}

أن لفظ "أقرؤكم" يفيد العموم، فيشمل الصبي المميز ، ولفظ "أصغركم" عام أيضاً فيشمل من هو أصغر سناً من غيره، ويشمل الصبي المميز، فمن كانت صفته أنه أقرأ فإنه المقدم وإن كان أصغر، وهذا يدل على صحة إمامة الصبي

المميز بالبالغين ما كان أقرههم (').

ونوقش هذا: بأن ظاهر الحديث المراد منه: تقدم الأقرا على الأسن، على أن

تطرق الاحتمال يُسْقِط الاستذلال (r).

وأما الأثر :

ا - عن الأشعث بن قيس رضي الله عنه أنه قدم غلاماً، فقيل له أو عابوا

عليه، فقال: ما قدمته، ولكن قدمت القرآن ().

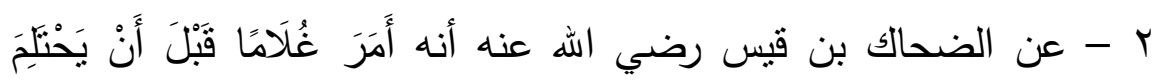

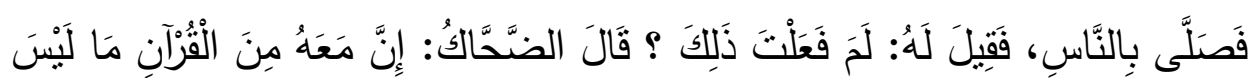

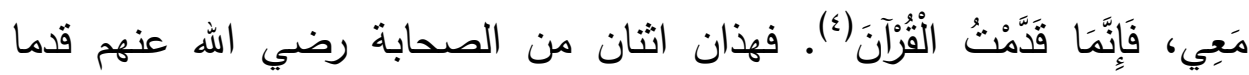

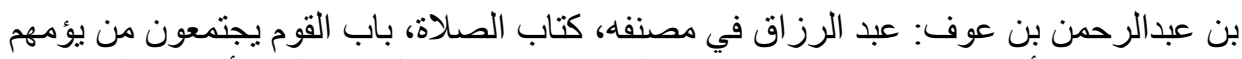

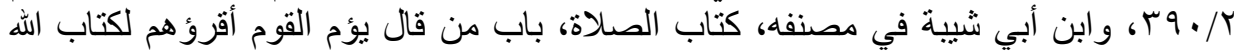

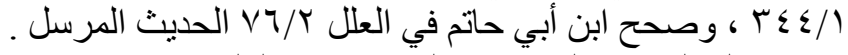

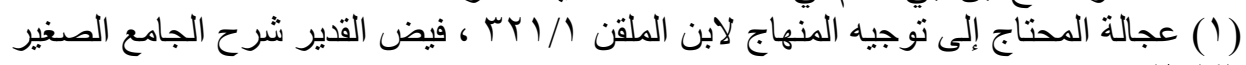
. ، $\leqslant\rceil \leqslant / 1$

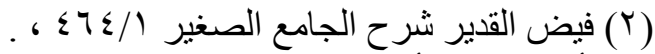

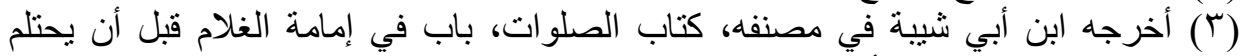

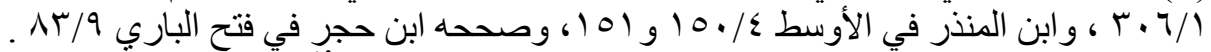

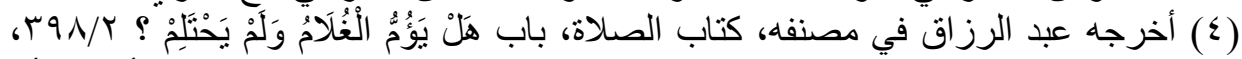

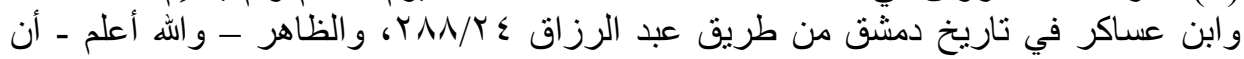

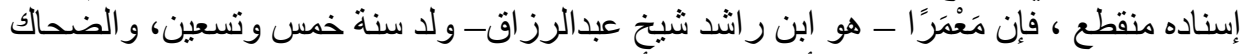

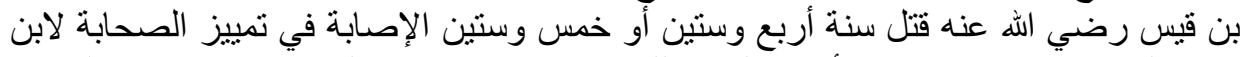

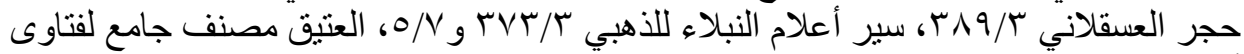

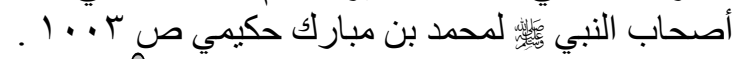




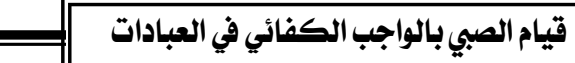

غلامين لم يلغا الحلم لإمامة الصلاة بالبالغين، لما كانا أكثر حفظاً للقرآن من غيرهما"). ونوفث أثثر الأثعت بن قيس رضي الإنهة عنه بأنه: لعل الغلام هاهنا

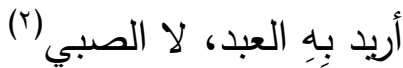

ويمكن الجواب عنه: بأن الغلام إذا أطلق فالمراد به من هو من دون البلوغ،

وهذا واضح من أثر الضحاك بن قيس رضي الله عنه ـ.

وأما المعقول: فمن ثلاثة أوجه :

الأول: أن الصبي المميز عدل تصح صلاته، فصحت إمامته كالبالغ (").

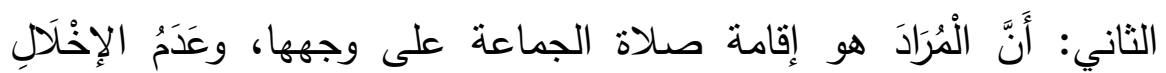

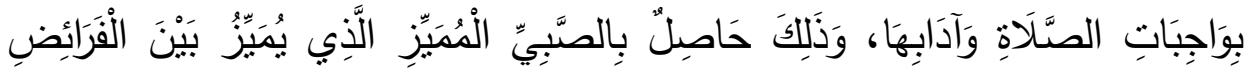

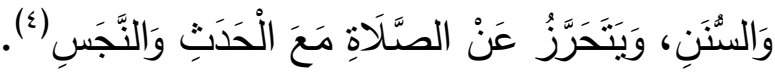

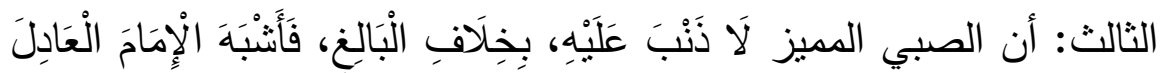

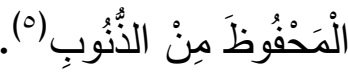

القول الراجح: والراجح - والله أعلم - هو القول بصحة إمامة الصبي المميز

للبالغين؛ لقوة أدلته من النقل والعقل، ومدار الترجيح على حديث عمرو بن سلمة رضي اله عنه وهو حديث صحيح في النقل، واضح الدلالة على صحة إمامة الصبي المميز، والاعتراضات الواردة عليه لا تقدح في الاستدلال به، يقول الثيخ

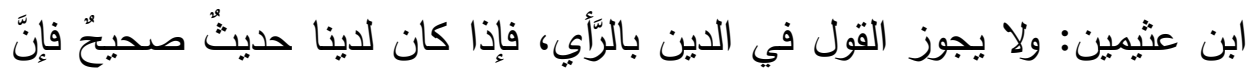

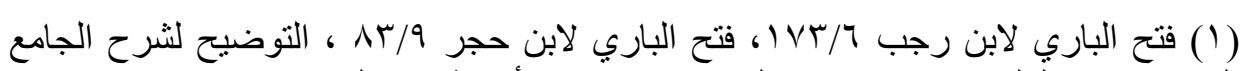

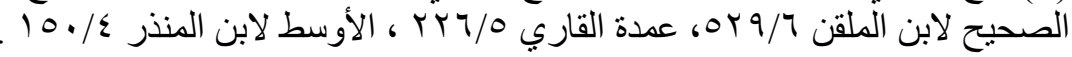

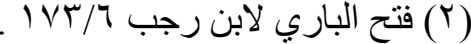

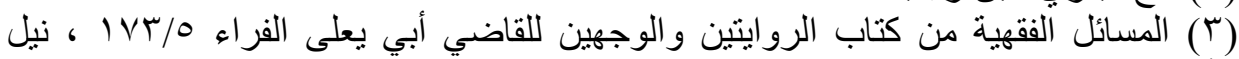

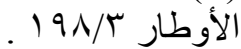

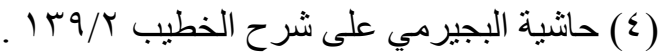

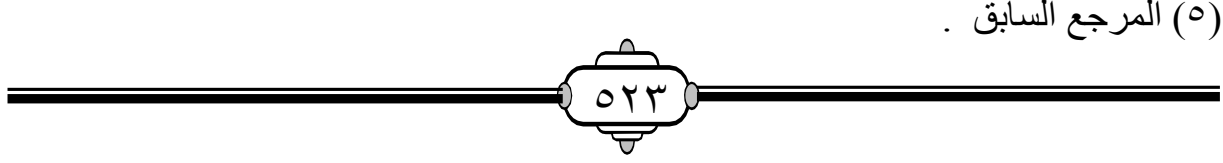




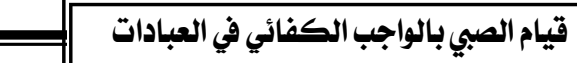

الرأيَ أمامَه ليس بشيءً('). لكن ينبغي أن لا يقدم الصبي المميز إلا إذا كان أحفظ

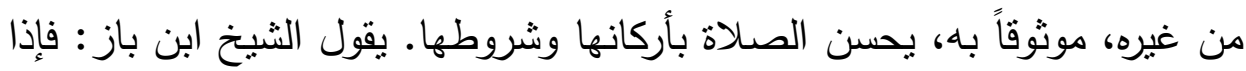

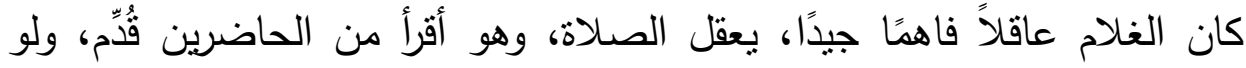

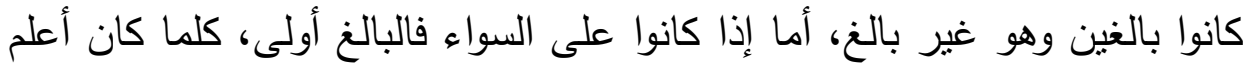

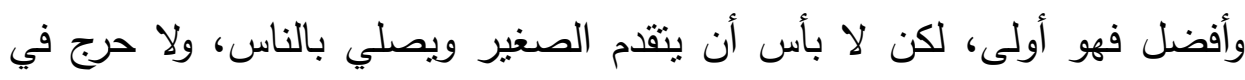

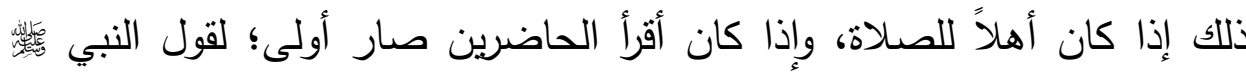

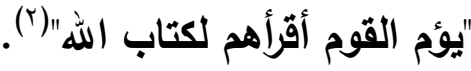

وإذا سلم القول بصحة إمامة الصبي المميز بالبالغين في صلاة الجماعة في

الصلوات الخمس المفروضة، فإنه يسقط بذلك فرض الكفاية، على القول المرجوح- بأن صلاة الجماعة فرض كفاية.

المطلب الثالث: حكم صلاة العيدين وانعقادها بالصبي وفيه فرعان: الفرع الأول: حكم صلاة العيدين

اختلف الفقهاء في حكم صلاة العيدين: هل هي سنة، أم واجبة على الأعبان، أم فرض كفاية؟ على ثلاثة أقوال:

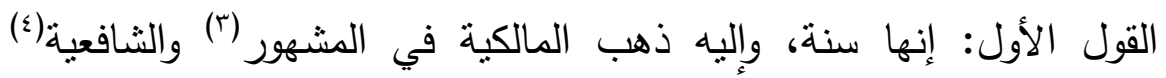

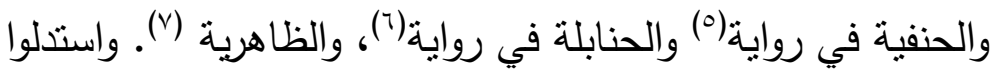

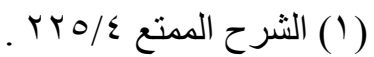

(Y) الموقع الرسمي لسماحة الثيخ الإمام ابن باز على الثبكة العنكبوتية - فتناوى الجامع الكبير

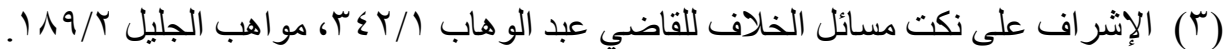

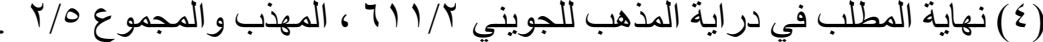

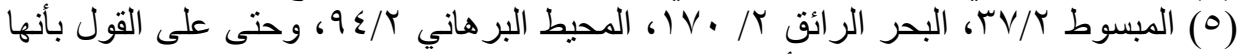

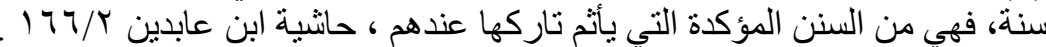

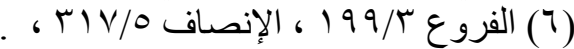

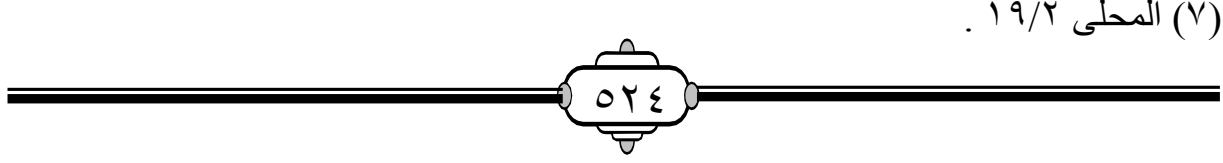




\section{قيام الصبي بالواجب الكفائي في العباداتص}

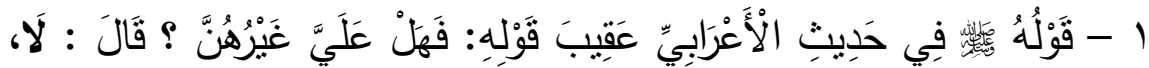

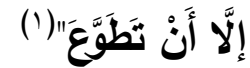

وهذا يدل على عدم وجوب الصلوات الخارجة عن الصلوات الخمس، ومنها

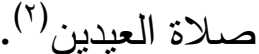

r- أنها لو كانت واجبة لشرع لها الأذان والإقامة، كسائر الصلوات

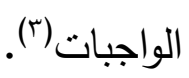

القول الثاني: إنها واجبة على الأعيان، وإليه ذهب الحنفية في الأصح(؛)، وبعض المالكية(0)، والحنابلة في رواية اختارها ابن تيمية(؟). واستدلوا على ذلك بما

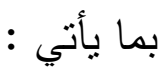

1 - قَوْله نَعَالَى :

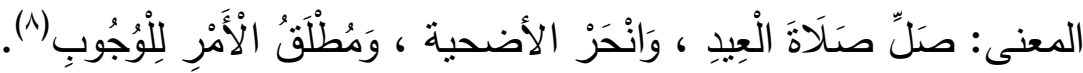
ب - مُوَاظَبَةُ النَّبِِّ

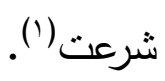

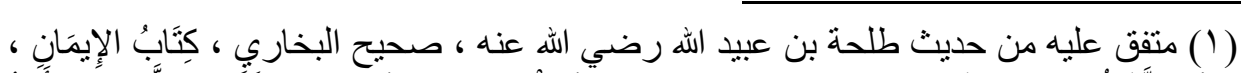

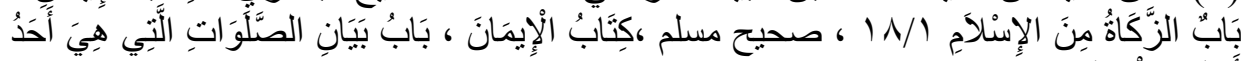

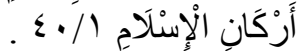

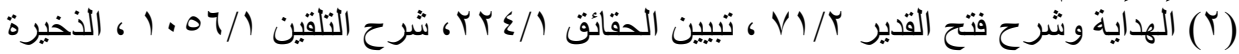

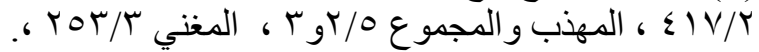

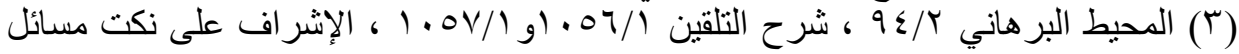

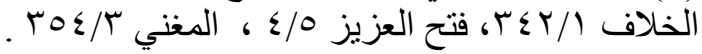

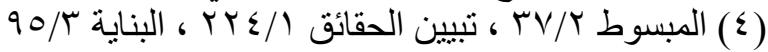

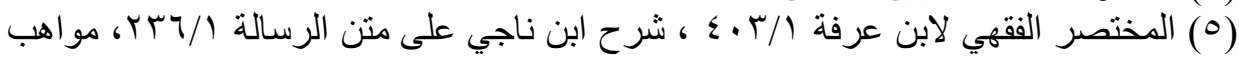

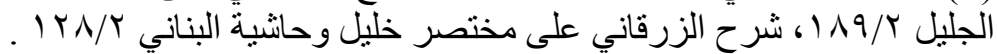

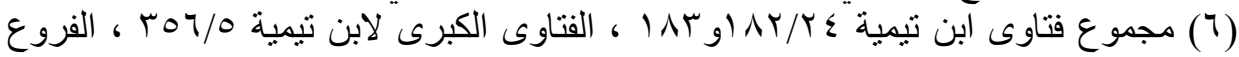
ال

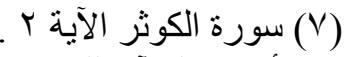

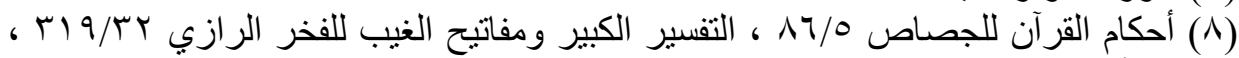

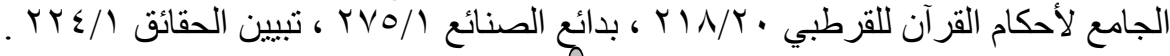




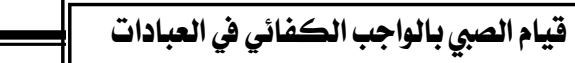

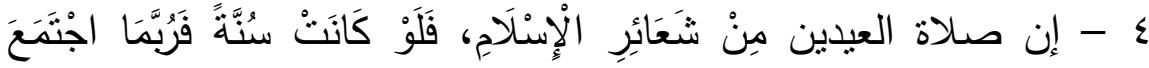

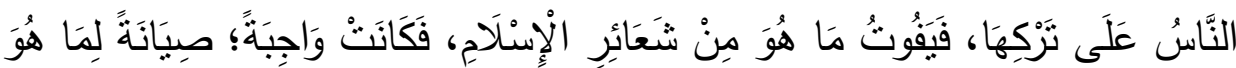

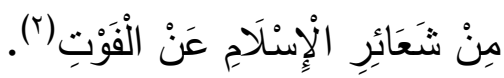

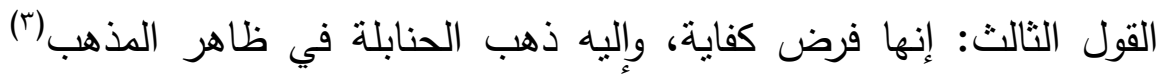

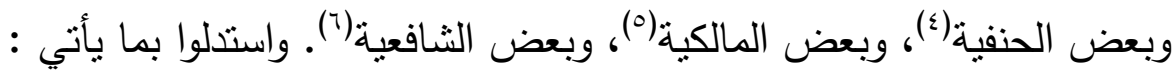

\section{أولا : الاليل عَلَى وُجُوِيهَِا فِي الْجُمْلَةِة :}

- أَمُْ اللَّهِ نَعَالَى بِهَّا بقوله:

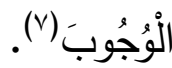

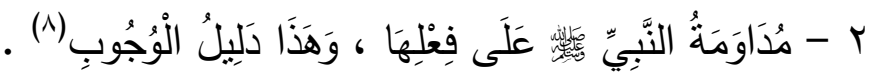

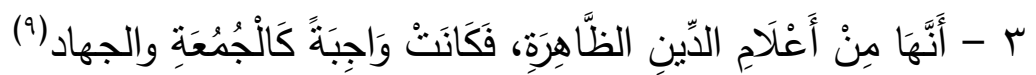

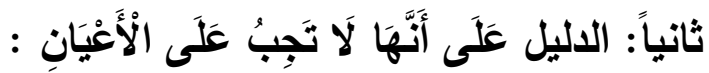

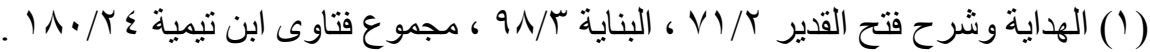

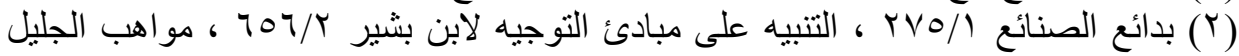

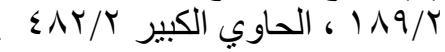

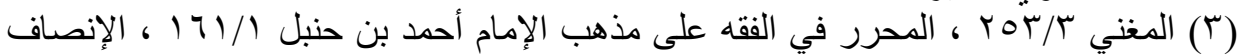

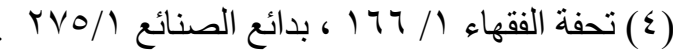

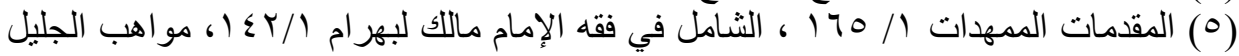
.119/4

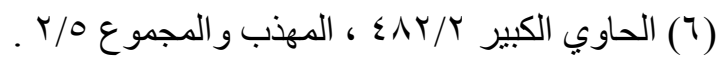

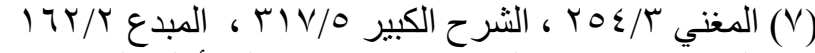

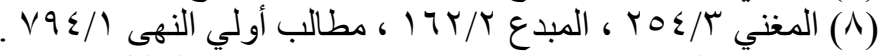

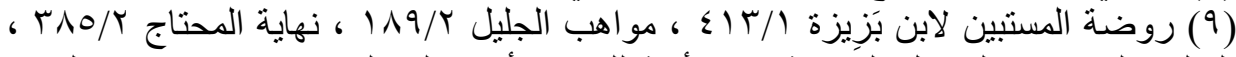

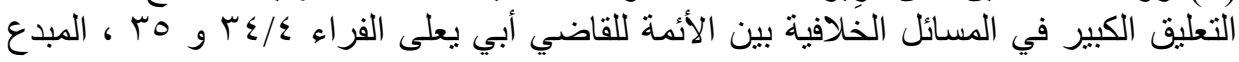

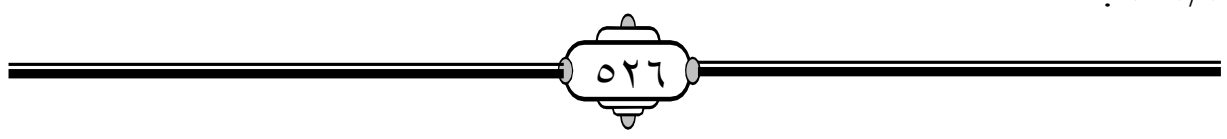


- قََوْلُهُ

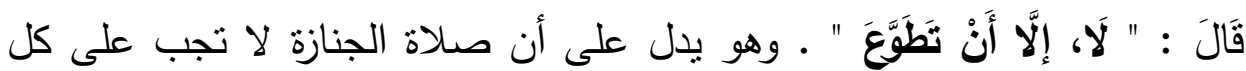

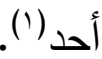

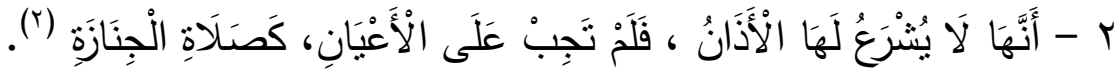

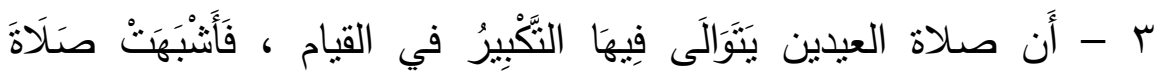

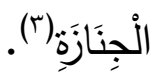

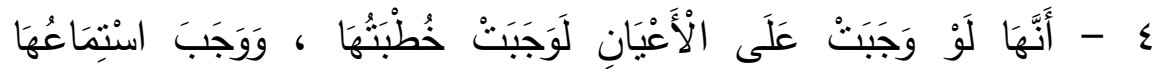

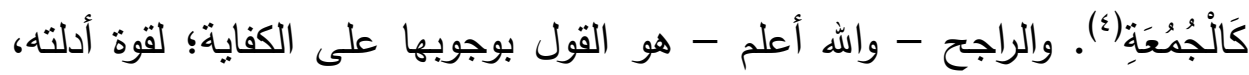

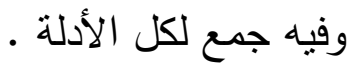

الفرع الثاني: حكم انعقاد صلاة العيدين بالعدد الذي فيه صبي مميز وإمامته فيها

1 - أما الحنفية - القائلون بوجوب صلاة العيدين وجوباً عينيَّا على المعتمد عندهم، وبعضهم قال إنها واجب على الكفاية- فقد ذهبوا إلى أنه يشترط لصلاة

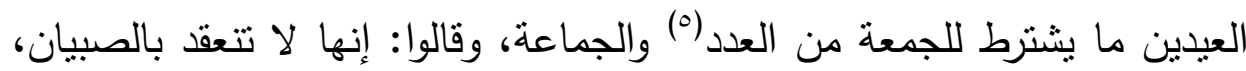

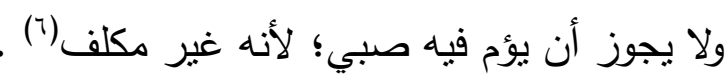

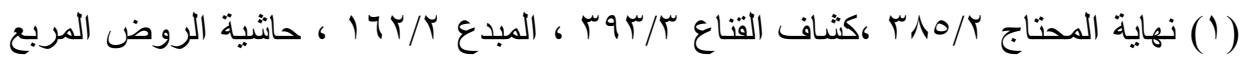

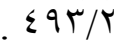

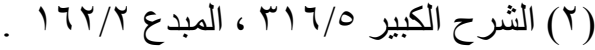

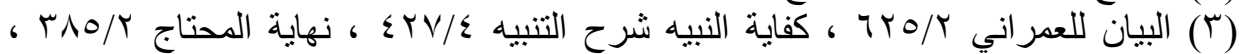

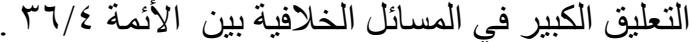

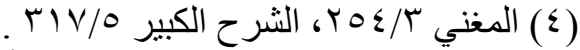

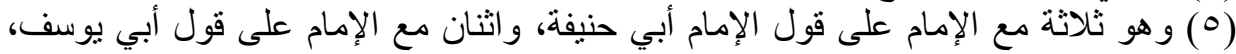

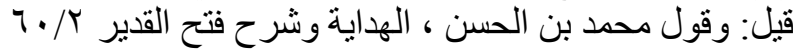

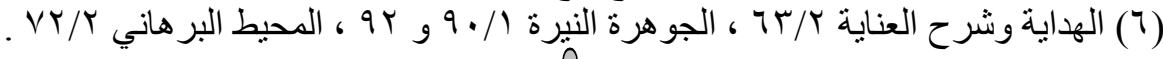




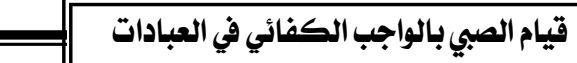

r - وأما المالكية -القائلون بسنية صلاة العيدين على المشهور، وبعضهم

قال بوجوبها على الكفاية- فذهبوا إلى أن صلاة العيدين كصلاة الجمعة في اثتراط

$$
\text { العدد (') والجماعة (r) }
$$

والجمعة لا تتعقد بالصبيان عندهم، فلا تتعقد صلاة العيدين بهم كذلك، ولا

$$
\text { يعتبرونهم في العدد (). }
$$

كما ذهبوا إلى أن الصبي المميز لا يجوز أن يؤم في صلاة الجمعة؛ لأنه

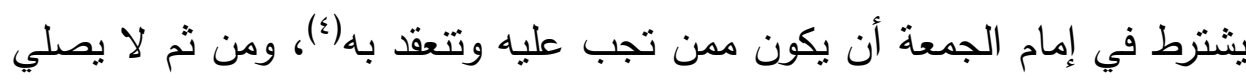
إماماً في صلاة العيدين على القول بوجوبها على الكفاية .

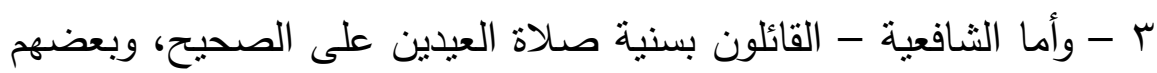
قال: إنها فرض كفاية - ذهبوا إلى أن الجماعة شرط في صلاة العيدين على قول الثافعي القديم). وقالوا: إن صلاة الجمعة لا تجب على الصبيان ولا تتعقد بهم(ج). لكنهم قالوا:

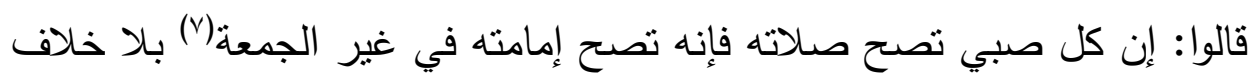
عندهم (^)

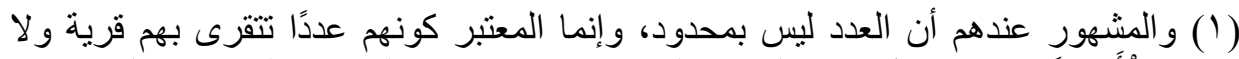

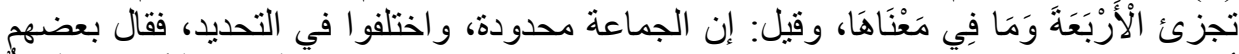

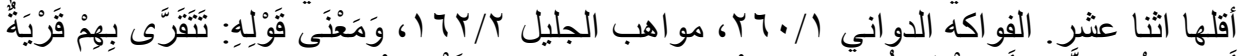

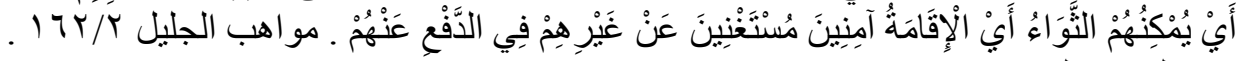

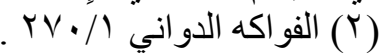

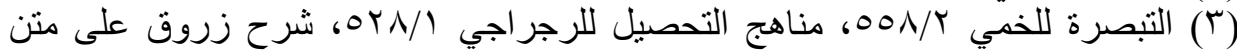

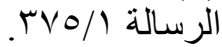

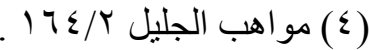

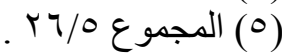

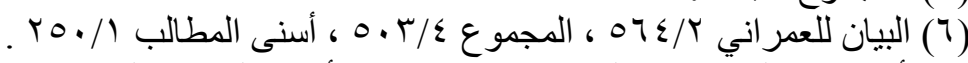

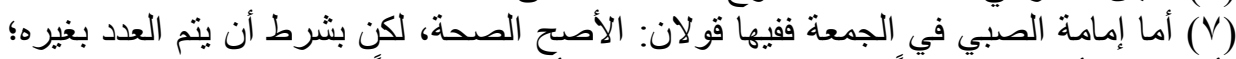

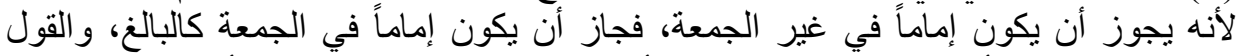

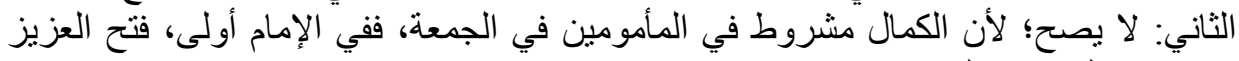

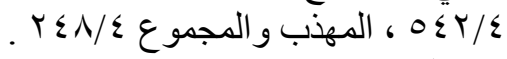

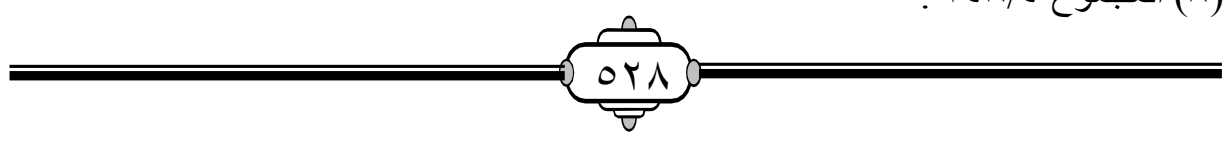




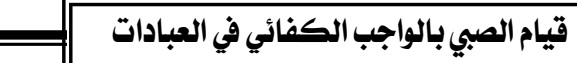

ـ - وأما الحنابلة- القائلون بوجوب صلاة العيدين على الكفاية في الصحيح

من المذهب- فذهبوا في الصحيح من المذهب إلى أنه يشترط لوجوب صلاة

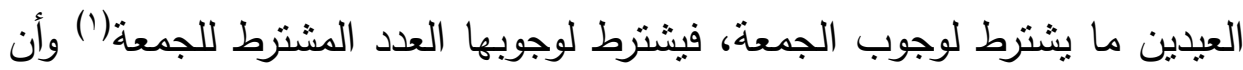
يكونوا من أهل وجوبها؛ لأنها صلاة لها خطبة راتبة، فأنثبهت الجمعة (؟). والمقصود صلاة العيد التي بسقط بها فرض الكفاية؛ لأن المنفرد تصح منه بعد صلاة الإمام، وبعد الوقت، فالعدد شرط وجوب صلاة العيد، لا شرط

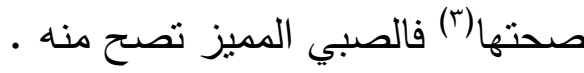

وبناءً على ما سبق فإن الصبي المميز لا تجب عليه صلاة العيدين، ولا

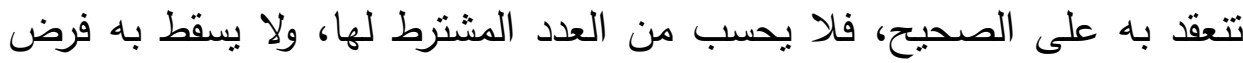
الكفاية . الك به

وأما إمامته فيها فقال ابنُ عَقِل: يُخرَّجُ في صححَّة إمامَةِة ابنِ عشر وجه -

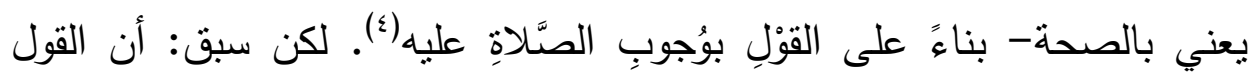
بوجوب الصلاة على الصبي ابن عشر سنين قول مردود لا يعول عليه . والخلاصة: أن فقهاء الدذاهب الأربعة يقولون: إن الصبي المميز لا تتعقد به

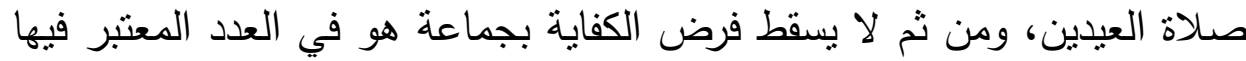

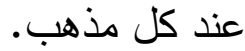

أما إمامته في صلاة العيدين فقد أجازها الثافعية، والحنابلة في قول ضعيف عندهم، ولعل هذا القول هو الراجح؛ لما سبق من صحة إمامة الصبي المميز، إذا لهاب (1) وهو أربعون رجلاً من أهل وجوبها في ظاهر الدذب ، المغني ؟/ ع.ب ، الإنصاف 191/0

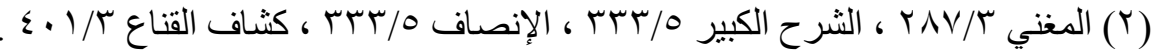

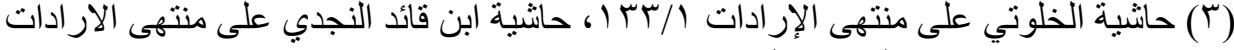

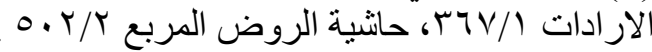

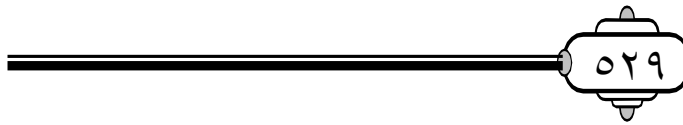

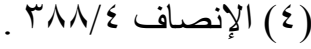




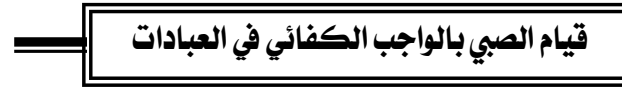

كان عاقلاً فاهمًا جيدًا، يعقل الصلاة، وهو أقرأ من الحاضرين، لكن مع مراعاة أن يتم العدد بغيره ، ويسقط بذلك فرض الكفاية، والله أعلم .

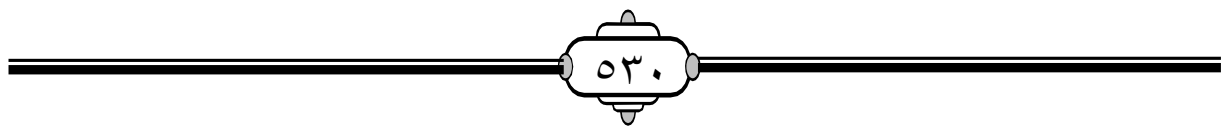




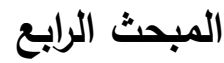 \\ قيام الصبي بالواجب الكفائي في الجنائز}

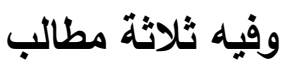

\section{المطلب الأول: حكم تفسيل الصبي المميز غيره}

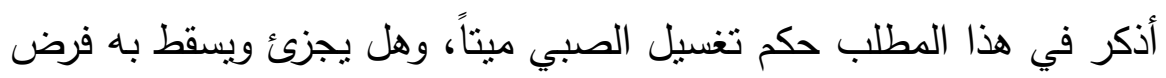
الكفاية؟ ولكن قبل ذلك أبين حكم تغسيل الميت: هل هو فرض كفاية أم مستحب؟ وذلك في الفرعين الآتيين : الفين

\section{الفرع الأول: حكم تفسيل الميت}

اختلف الفقهاء في تغسيل الميت(1): هل هو فرض كفاية، أم مستحب؟ على لـى

القول الأول: ذهب أكثر أهل العلم، ومنهم الحنفية(() والمالكية في المشهور (r)

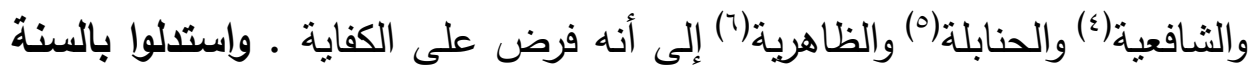

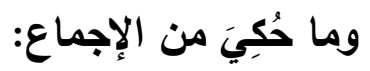

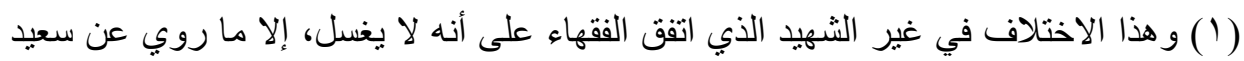

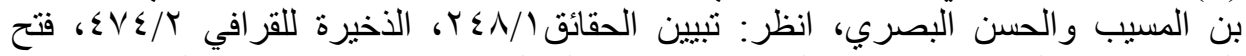

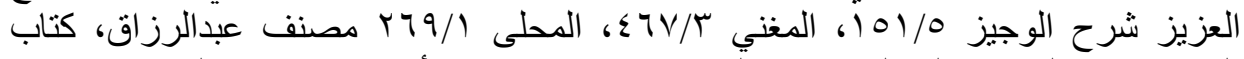

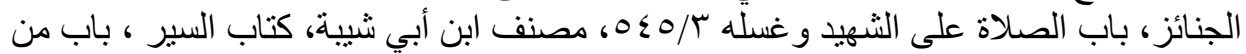

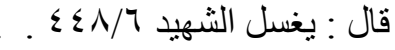

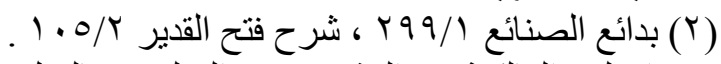

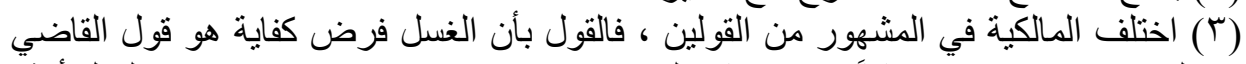

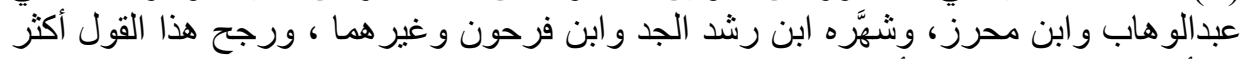

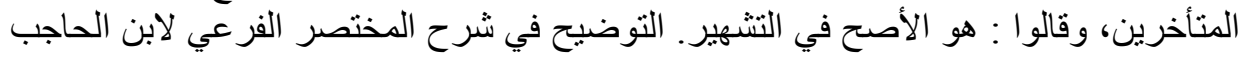

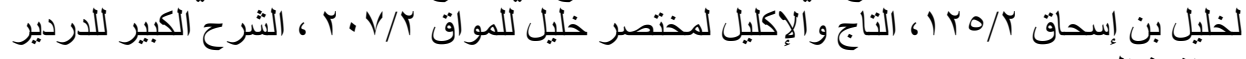

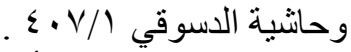

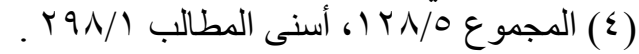

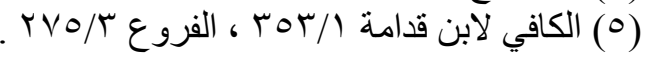

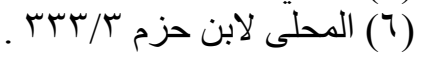


1

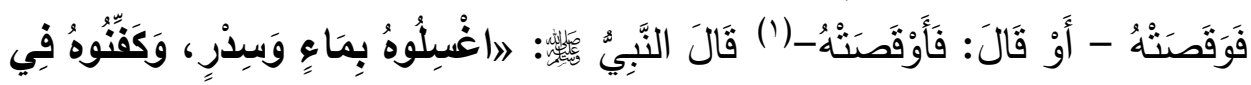

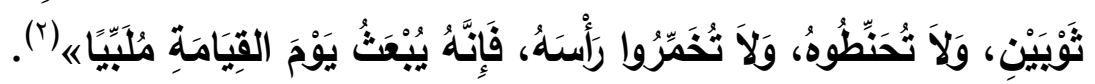

\section{ووجه الالالة من الحديث :}

أن النبي

على أن غسل الميت واجب ، ويسقط بقيام البعض به، فهو واجب على الكفاية(؟). ونوقش هذا الاستدلال: بأن الأمر بغسل المحرم لا بدل على الوجوب، بل

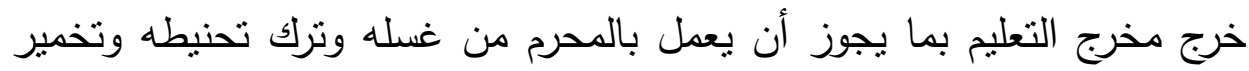
رأسه (๕).

وأجيب عن ذلكك: أن القول بأن الأمر خرج مخرج التعليم ووصف الغسل غير مسلَّم، بل إنه تضمن الأمر الذي يفيد الوجوب، وتضمن كذلك الصفة، وقد توارد

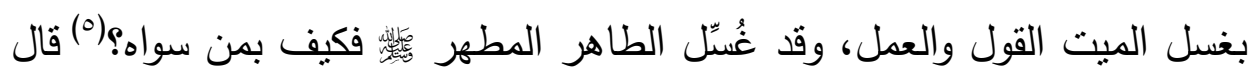
الروياني: وأصل هذا - أي كون غسل الميت فرض كفاية - أن عليًّا والفضل بن

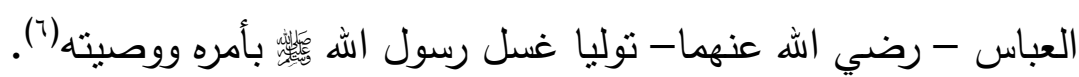
(1) الوقص: كسر العنق، و الظاهر أن: (أو) شك من الراوي عن ابن عباس، ووقص وأوقص:

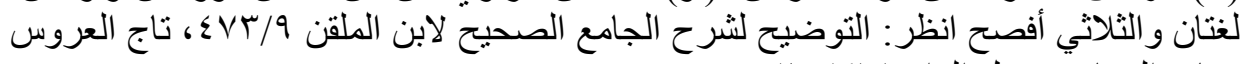

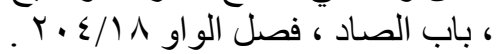

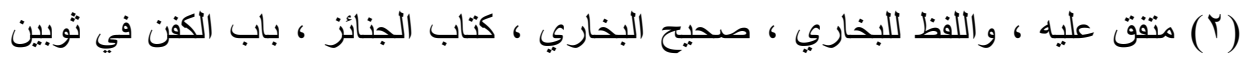

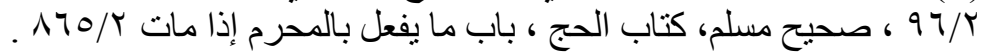

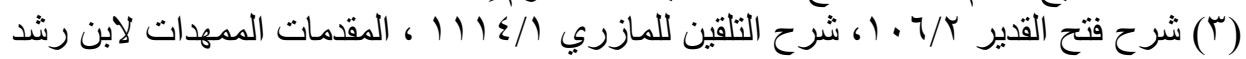

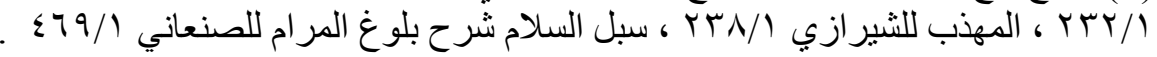

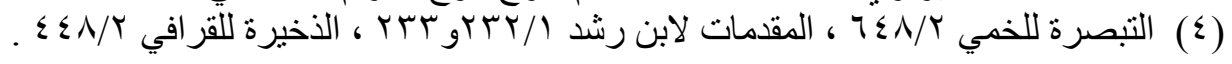

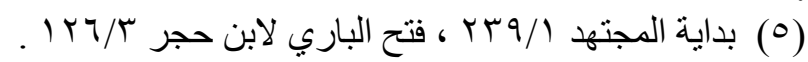

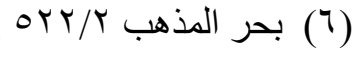

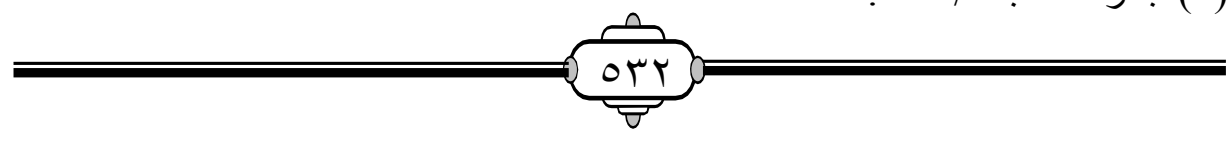




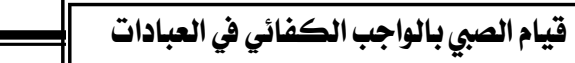

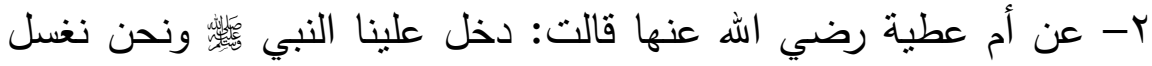

ابنته(') فقال: "اغنلنها ثلاثاً

أو خمساً أو أكثر من ذلك إن رأيتن ذلك بماء وسدر ... الحديث"(؟) .

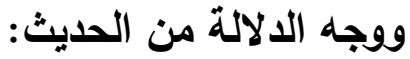

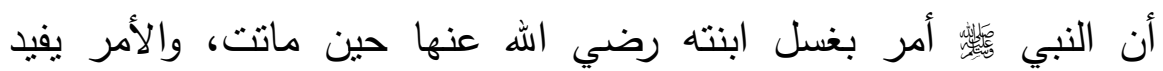

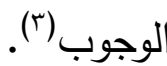

ونوقش هذا الاستدلال من وجهين:

الأول: أن الأمر بالغسل خرج مخرل من وجئ التعليم بصفة الغسل، كما في الحديث

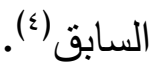

ويجاب عنه أيضاً بما سبق أن الأمر يتضمن ما يفيد الوجوب والصفة

معاًً)

الثاني: أن قوله

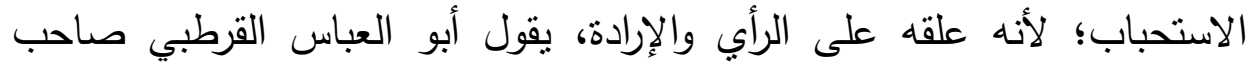

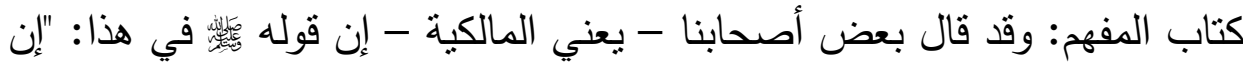

رأيتن ذلك" يقتضي إخراج الأمر بالغسل عن الوجوب؛ لأنه فوضه إلى نظرهن(").

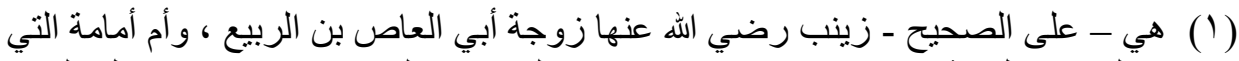

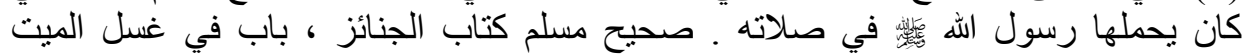

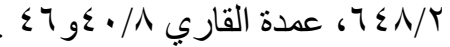

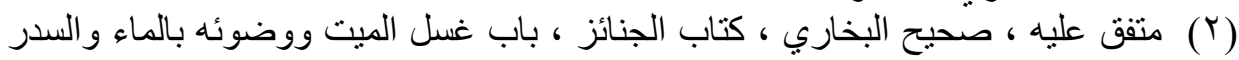

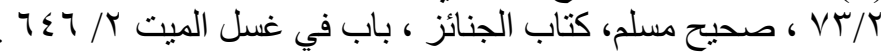

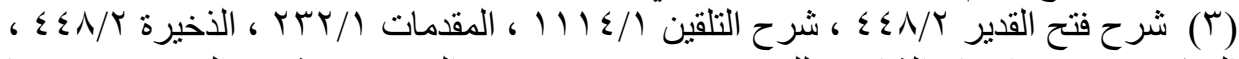

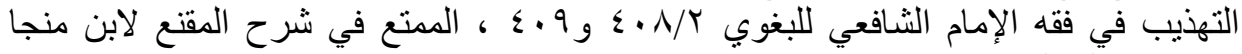

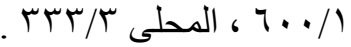

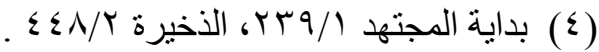

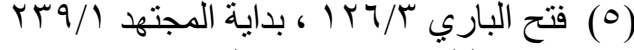

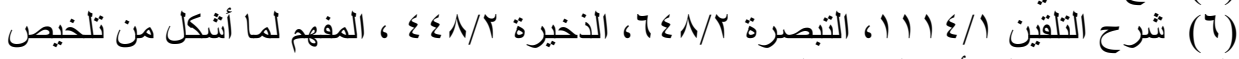

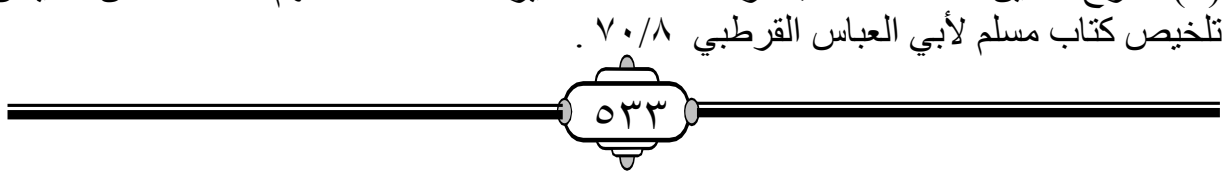




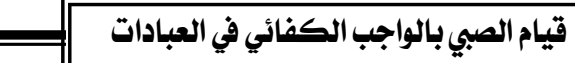

وأجيب عن هذا: بأن رد هذا التقييد "إن رأيتن ذلك" إلى الأمر بالغسل بعيد

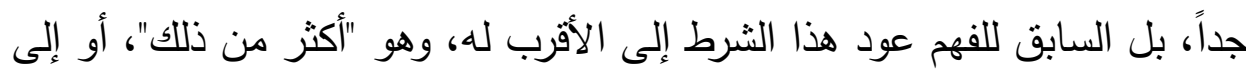

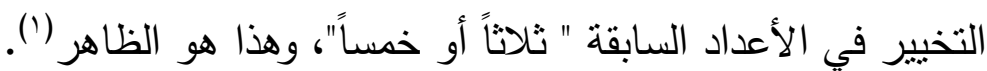

وأما الإجماع: فقد حكى كثير من أهل العلم الإجماع على أن غسل الميت فرض كفاية إذا قام به البعض سقط عن الباقين، ومن هؤلاء من الحنفية: علاء

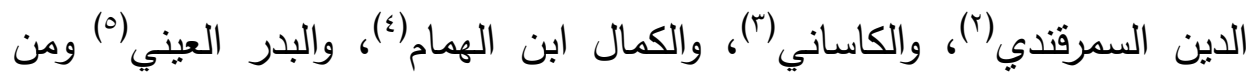

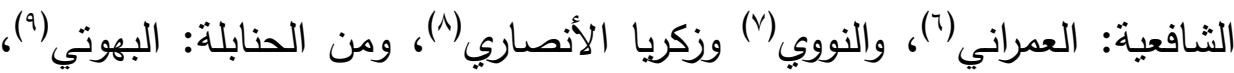

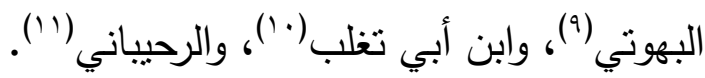
ونوقش هذا: بأن دعوى الإجماع لا تصح؛ إذ قال كثير من فقهاء المالكية باستحباب غسل الميت، لا أنه فرض كفاية ، بل قيل - كما سيأتي-: إنه مشهور

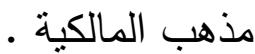

قال ابن حجر العسقلاني: وقد نقل النووي الإجماع على أن غسل الميت فرض كفاية، وهو ذهول شديد فإن الخلاف مشهور عند المالكية، حتى قال

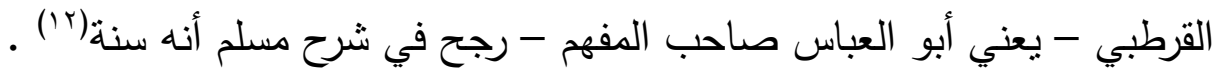

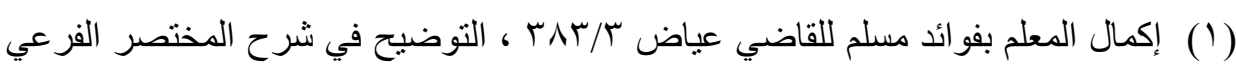

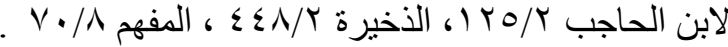
(r) (r) ت تحفة الفقهاء

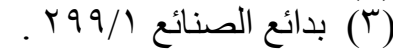

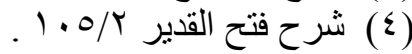

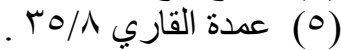

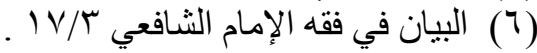
( الجموع (V)

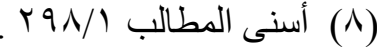

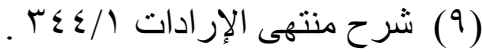

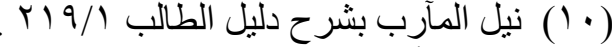

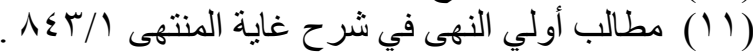

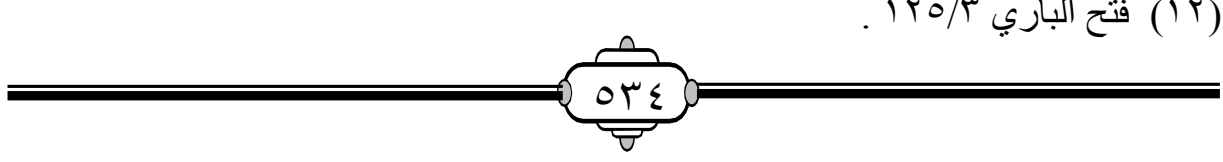




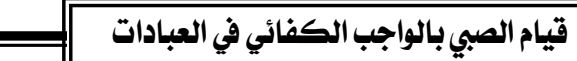

القول الثاني: إن غسل الميت مستحب، وإليه ذهب بعض المالكية(') .

$$
\text { وقيل: إنه مشهور المذهب(؟). }
$$

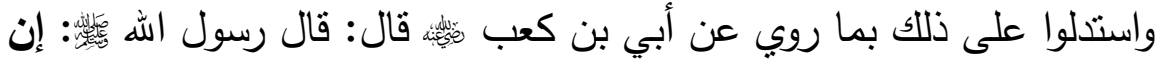
آدم غسلته الملائكة بماء وسدر، وكفنوه وألحدوا له ودفنوه، وقالوا: هذه سنتكم

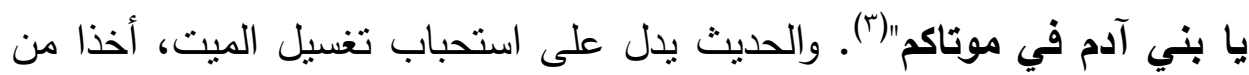

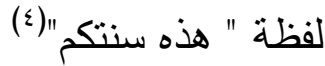

ويمكن أن يناقش هذا: بأن لفظ "سنتكم" في الحديث لا يدل على مجرد الاستحباب؛ لأن "السنة" معناها الطريقة، ويدل لهذا أنه جمع مع التغسيل التكفين والدفن، وهما بلا شك واجبان، وبدل له أيضاً: الأدلة الأخرى السابقة قولاً وعملاً على الأمر بغسل الميت الدالة على الوجوب(ه). القول الراجح: والراجح هو قول أكثر أهل العلم: إن تغسيل الميت فرض على الكفاية، إذا قام به البعض سقط الإثم عن الباقين؛ لقوة وظهور أدلتهم قولاً وعملاً، وهذا ما جرى عليه العمل منذ النبي

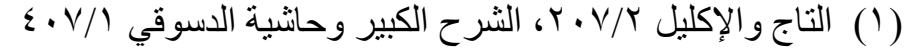

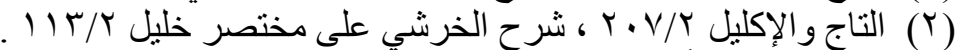

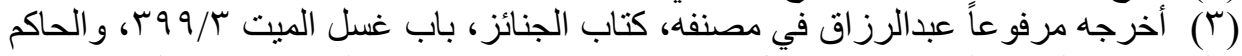

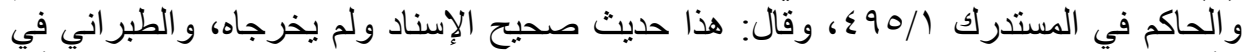

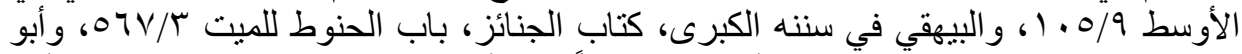

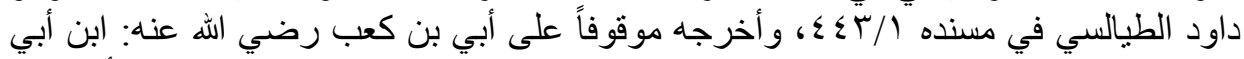

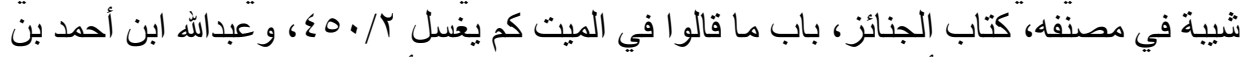

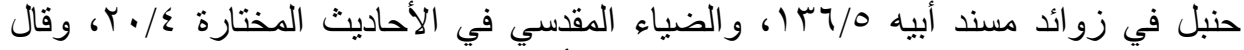

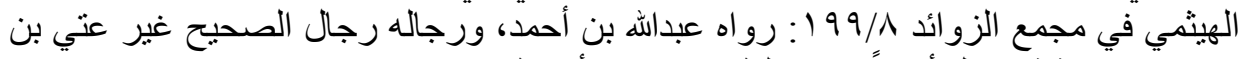

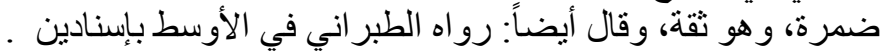

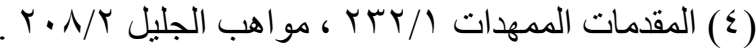

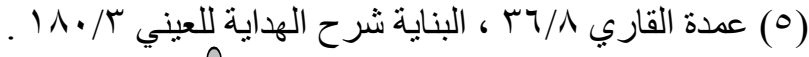




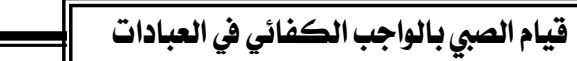

المخالفين وهم بعض المالكية، بما أمكن من مناقثتهم والرد عليهم والجواب عما ذكروه • والله أعلم.

\section{الفرع الثاني: حكم تغنيل الصبي للميث}

أجمع أهل العلم على أن الصبي غير المميز لا يصح أن يغسل الميت، لعدم

عقله وتمبيزه، وعدم تصور وقوعه منه على الوجه المشروع.

ثم اختلفوا في حكم تغسيل الصبي المميز غيره إلى قولين :

القول الأول: ذهب جمهور الفقهاء ومنهم الحنفية(') والمالكية(؟) والثافعية في

الأصح() والحنابلة في الصحيح من المذهب()) إلى أنه يجوز أن يغسل الصبي

المميز غيره، ويسقط فرض الكفاية بذلك .

\section{واستدلوا بما يأتي:}

1 - أنه تصح طهارته لنفسه، فيصح أن يطهر غيره كالكبير (ن). r - إن الغسل لا تجب فيه النية، ولا تشترط في صحته؛ إذ المقصود منه

النظافة، وهي غير متوقفة على النية(ا) . r - إن فعل الصبي وإن لم يقع فرضاً، بل يقع نفلاً، إلا أن المقصود وهو تغسيل الميت قد وقع ووجد على وجهه، فسد مسد الفرض، فيكون مجزئًا مسقطاً

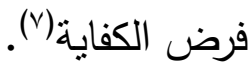

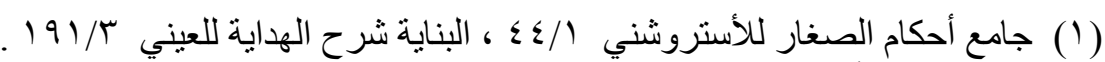

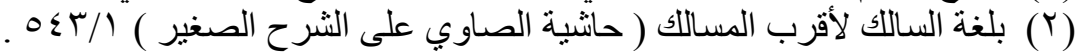

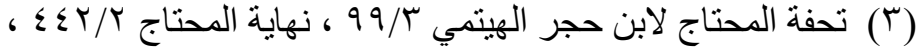

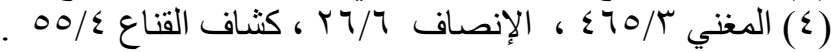

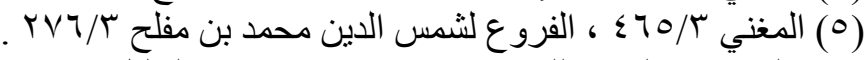

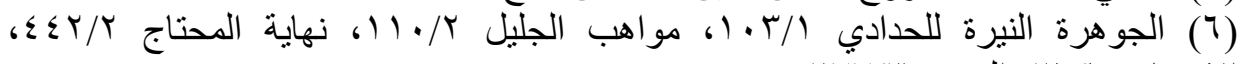

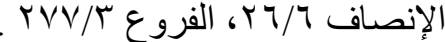

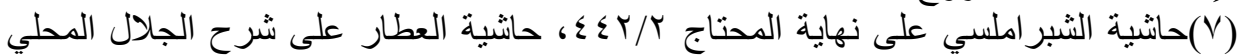

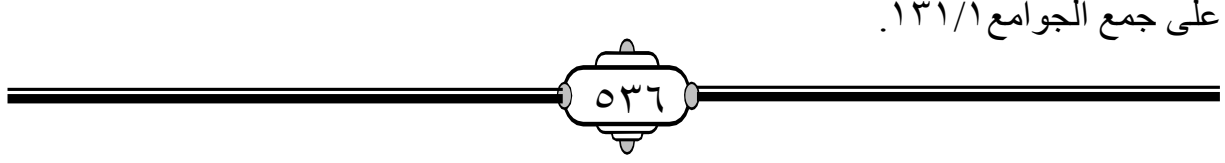




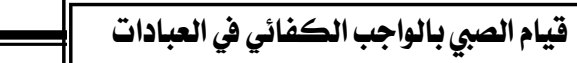

يقول ابن عابدين: إن الواجب نفس الغسل، فأما الغاسل فيجوز أن يكون أَيَّا

كان (')

ء - إن الصبي المميز لا يجب عليه وجوباً كفائياً تغسيل الميت لعدم تكليفه،

لكن إن فعله صح منه كالمسافر لا تجب عليه صلاة الجمعة، ولو صلاها سقط

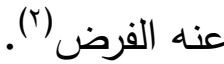

ه - إن الصبي المميز يصح له غسل الميت؛ لصحة العبادة منه لنفسه،

$$
\text { فصح أن يغسل غيره، لاعتبار نيته( آن. }
$$

7 - إن الصبي المميز عاقل من جملة المسلمين ومن جنس المكلفين،

فيكفي تغسيله للميت، كالفاسق يجوز لله ذللك، بجامع أن النقص حاصلة المل ومن في

كليهما (ई).

- V

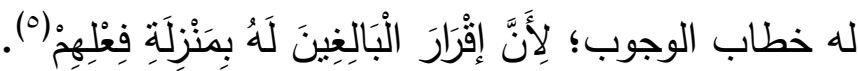

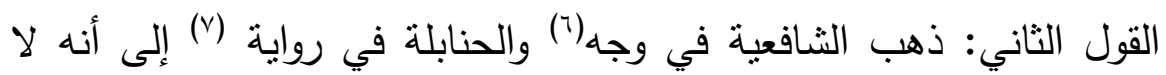

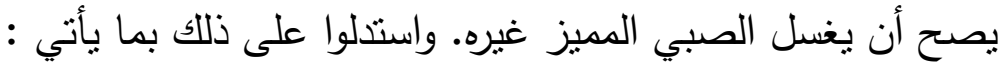

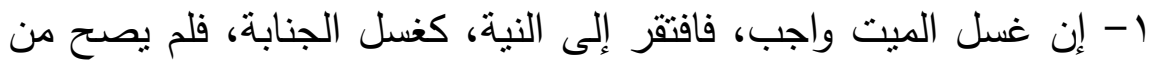

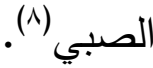

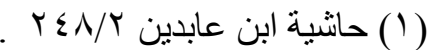

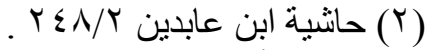

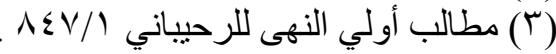

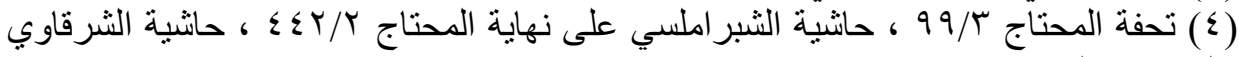

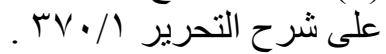

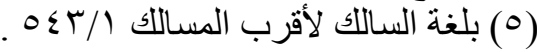

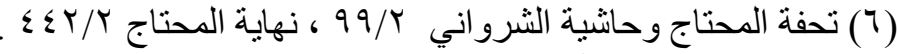

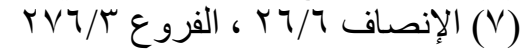

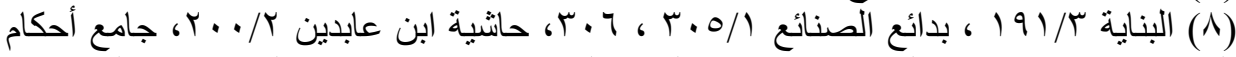

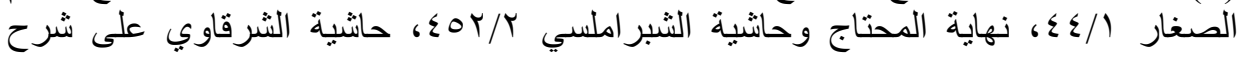

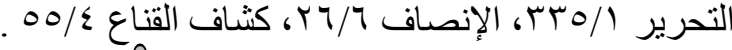




\section{قيام الصبي بالواجب الكفائي في العباداته}

ويناقش هذا: بأن للصبي المميز نيةً معتبرةً شرعًا -كما سبق-وبدليل صحة

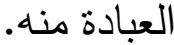

r- إن الصبي ليس أهلاً لأداء الفرض، بل يقع فعله نفلاً، فلا يسقط به

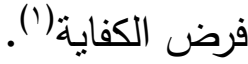

ويناقش هذا: بما سبق من أن فعل الصبي وإن لم يقع فرضاً، إلا أن المقصود وهو تغسيل الميت قد وقع على وجهه، فسد مسد الفرض، فيكون مسقطاً

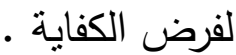

القول الراجح: والراجح - والهه أعلم -أن الصبي المميز - ذكراً كان أم أنثى - دأل

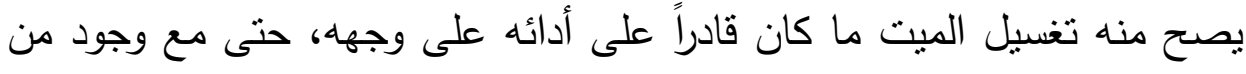

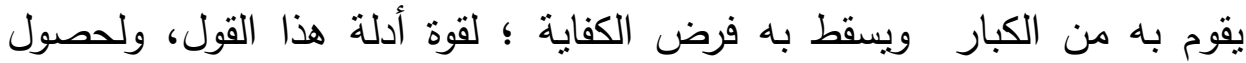

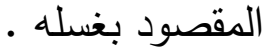

وفي بعض الحالات قد تكون هناك ضرورة لتغسيل الميت من صبي، كما لو مات رجل في سفر ليس معه إلا نساء ليس فيهن زوجته، أو ماتت امرأة ليس معها إلا رجال ليس فيهم زوجها، وكذللك في منل حالات الهرج والفتن وكثرة الحروب والدمار، حتى لو كان الصبي المميز -ذكراً أو أنثى - لا بحسن الغسل فإن الكبار يعلمونه تغسيل الميت، ويقوم الصبي بغسل الميت، والصبية بغسل

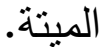

بل ذهب بعض الحنفية - كالكاساني وابن عابدين - في الحالة السابقة إلى

جواز أن يقوم الصبي الذي لا يشتهي بتغسيل المرأة، والصبية التي لم تنلغ حد

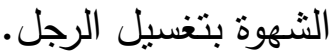

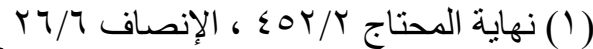




\section{قبيام الصبي بالواجب الكفائي في العباداته}

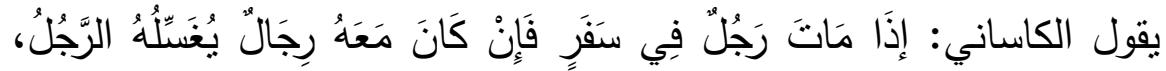

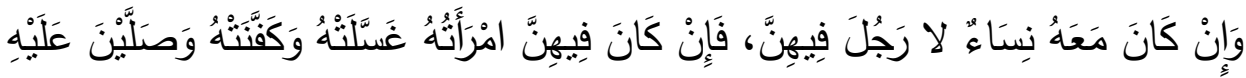

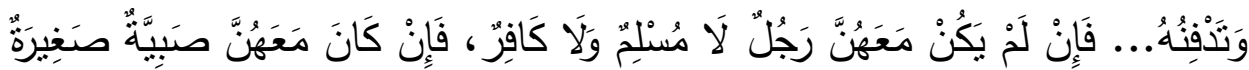

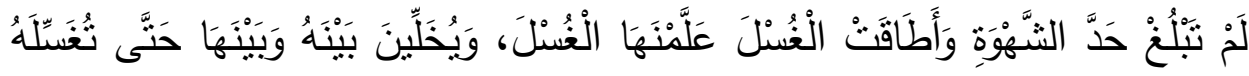

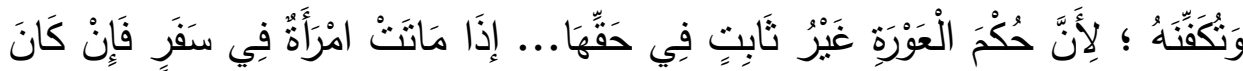

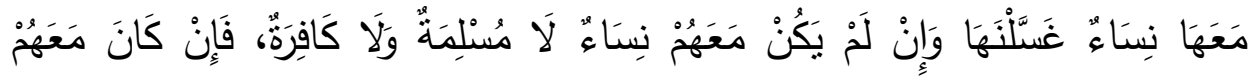

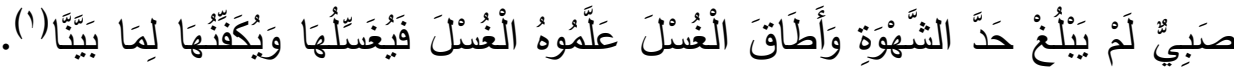

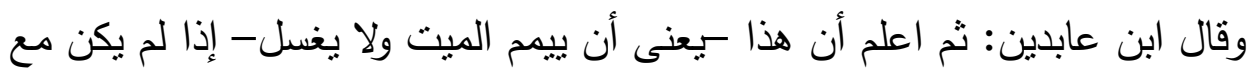

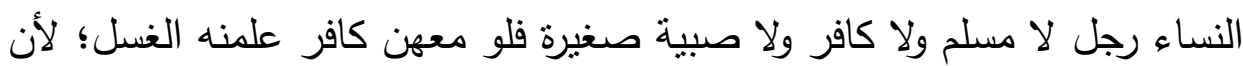
نظر الجنس إلى الجنس أخف، وإن لم يوافق في الدين، ولو معهن صبية لم تبلغ حد الثهوة وأطاقت غسله علمنها غسله؛ لأن حكم العورة غير ثابت في حقها، وكذا

في المرأة تموت بين رجال معهم امرأة كافرة أو صبي غير مشتهى ().

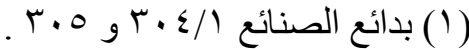

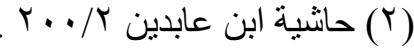


المطلب الثاني: حكم قيام الصبي بصلاة الجنازة دون البالغين

وأتتاول في هذا المطلب: حكم صلاة الجنازة: هل هي فرض كفاية أم سنة ؟

ثم حكم قيام الصبي بصلاة الجنازة ، وذللك في الفرعين الآتيين:

الفرع الأول: حكم صلاة الجنازة: اختلف الفقهاء في حكم صلاة الجنازة على ودى

القول الأول: إن صلاة الجنازة فرض كفاية عند أكثر أهل العلم، ومنهم

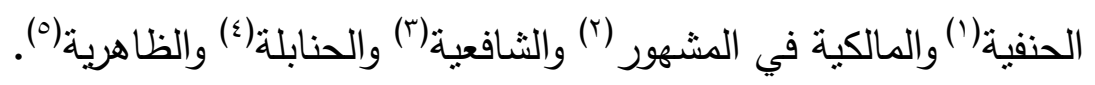

وقد استدلوا على كونها فرض كفاية بما يأتي :

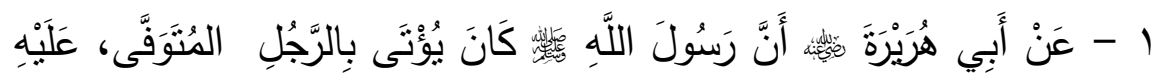

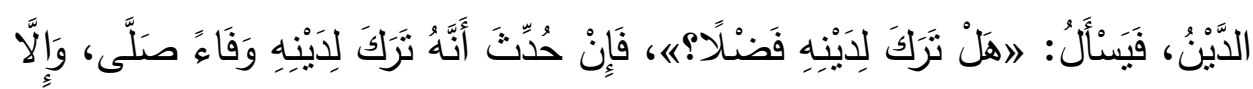

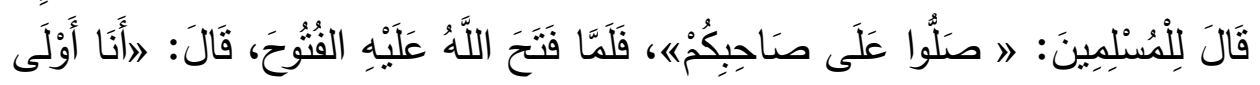

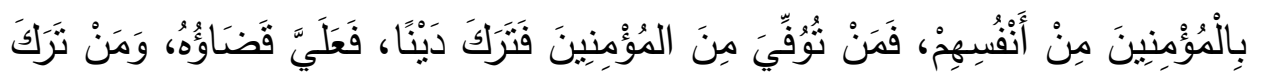

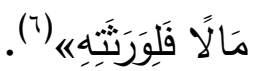

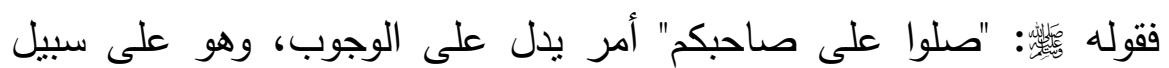

الكفاية فإذا قام به البعض سقط عن الباقين (v) .

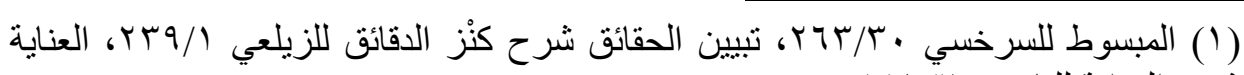

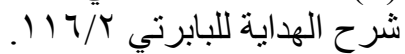

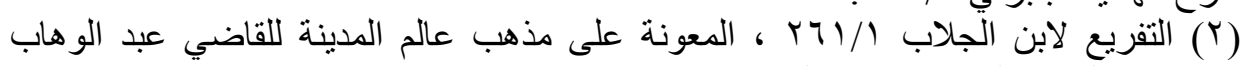

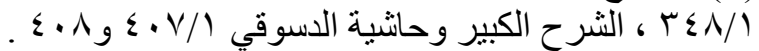

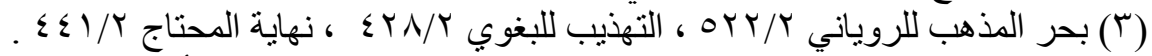

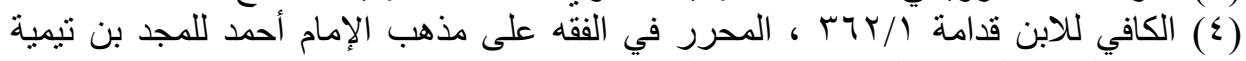

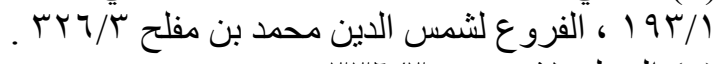

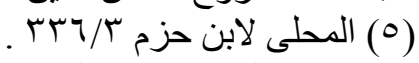

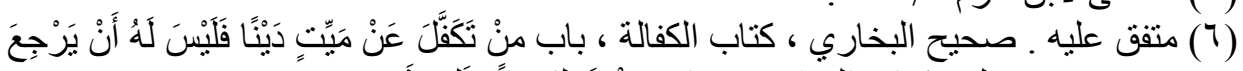

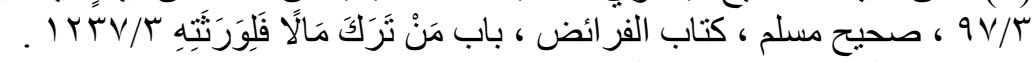

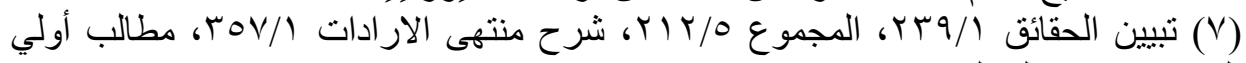
النهى

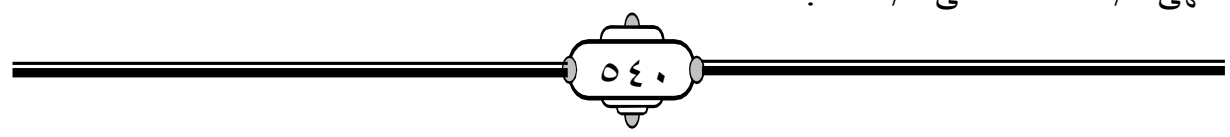




\section{قيام الصبي بالواجب الكفائي في العبادات}

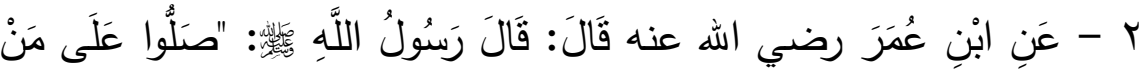

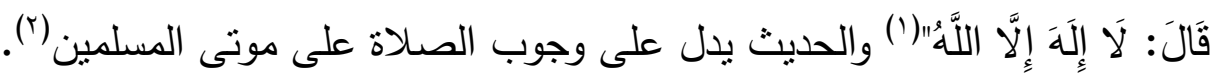

ونوقش هذا: بأن الحديث ضعيف، لا يصلح للاحتجاج به (r).

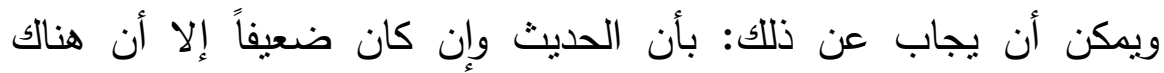

أحاديثَ وأدلةًً أخرى تجعل معناه صحيحاً (\&).

r - مواظبة النبي

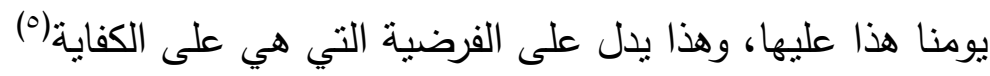

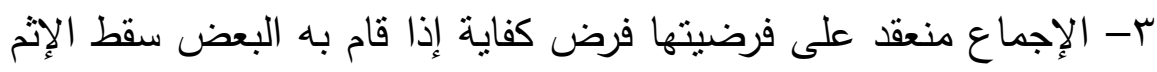

عن الباقين (7).

ويناقش هذا: بعدم التسليم بانعقاد الإجماع؛ إذ فيه خلاف بعض فقهاء

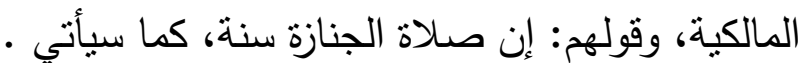

وأجيب عن هذا: بأن هذا خلاف شاذ لا يعتد به، يقول النووي: وََقَّْ نَقَلُوا

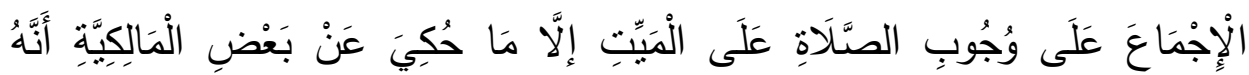

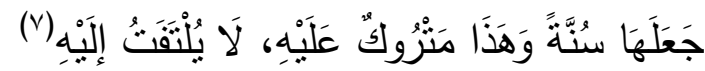

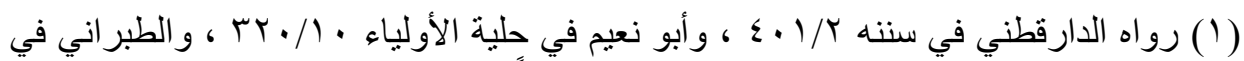

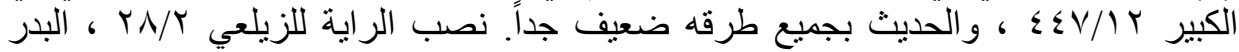

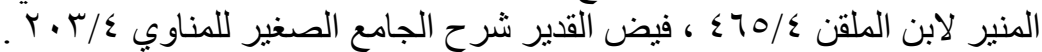

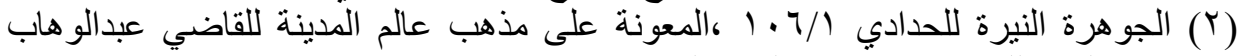

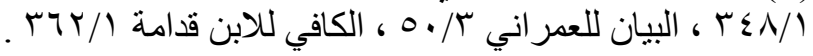

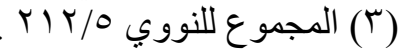

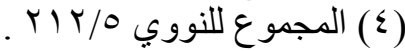

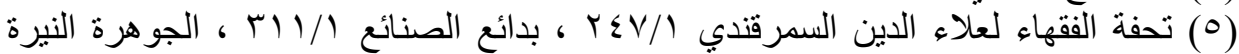

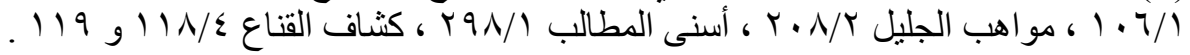

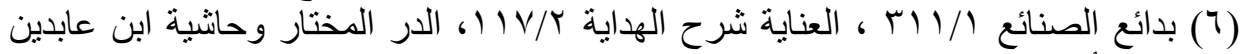

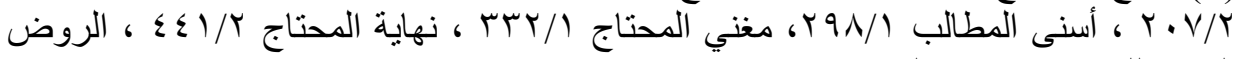

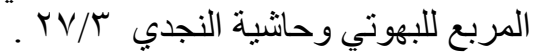

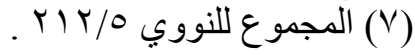

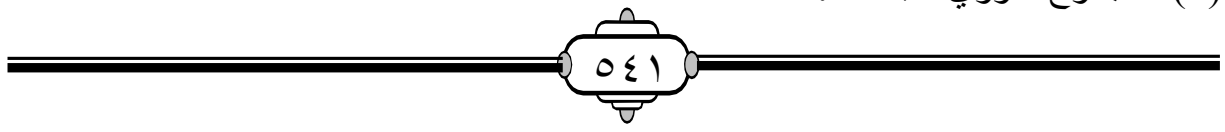




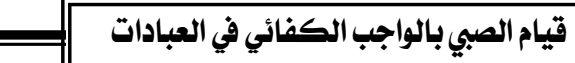

القول الثاني: ذهب بعض المالكية -كأصبغ- إلى أن صلاة الجنازة سنة

على الكفاية(') - (ل)

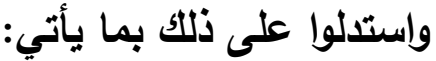

1 - في حديث طلحة بن عبيداله رضي الله عنه في قصة الرجل الذي جاء

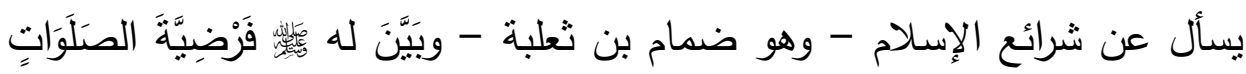

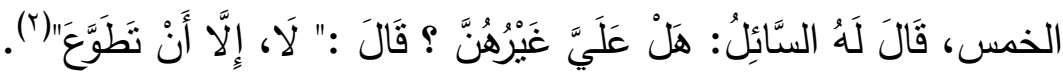

فلو كانت صلاة الجنازة فرضا لذكرها له له فئل

$$
\text { وَيَجَابُ عَنْ ذلك: كَانَ }
$$

بِأَنَّ الثرائع الدذكورة في الحديث ليست جميع الواجبات، ولا كل الدنهيات

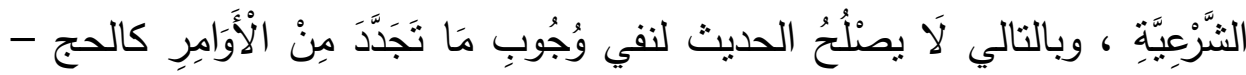

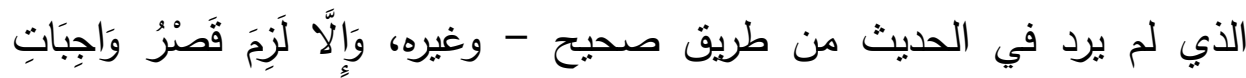

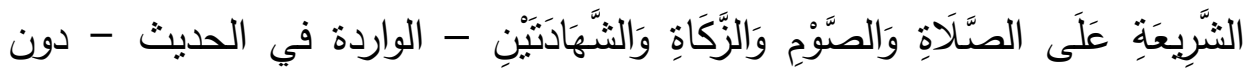

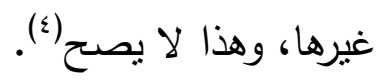

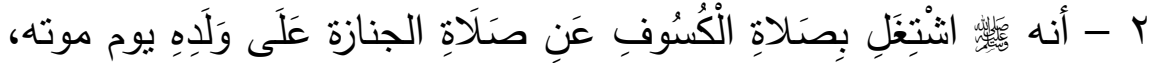

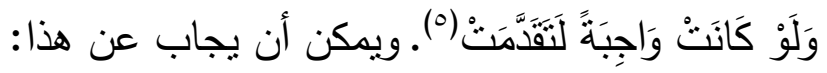

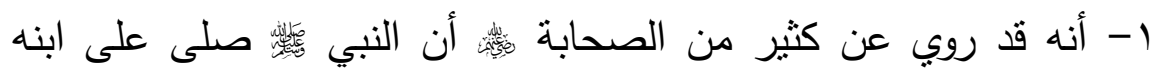

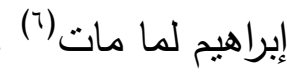

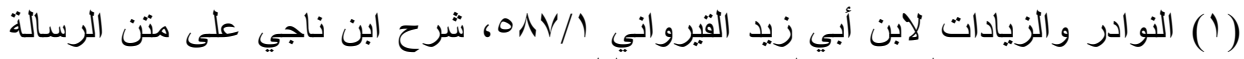
(T)

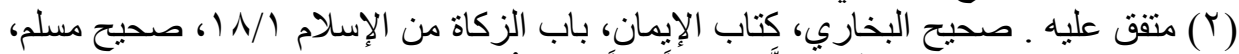

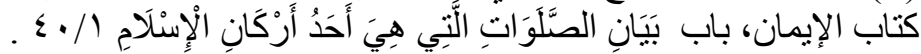

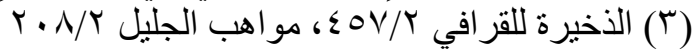

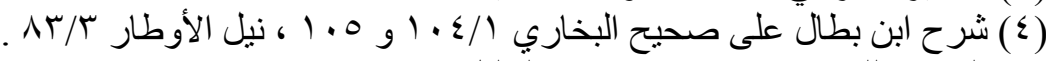

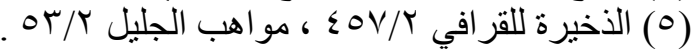

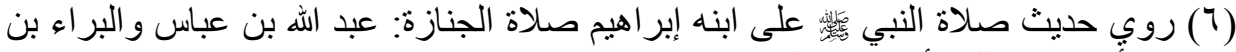

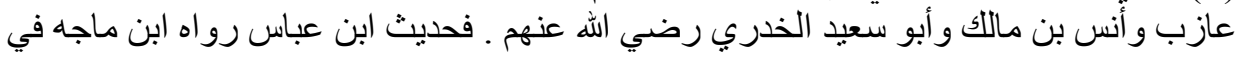

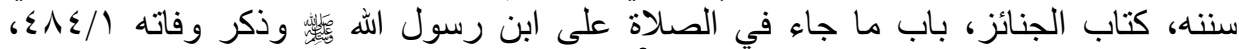




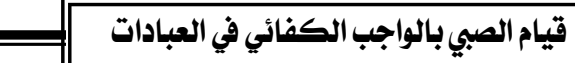

r- أنه يمكن حمل "الانشغال" على أنه لَّ قدم صلاة الكسوف لوجود سبيها،

وخوف فوتها على صلاته الجنازة على ولده، وتقديم صلاة الكسوف على صلاة

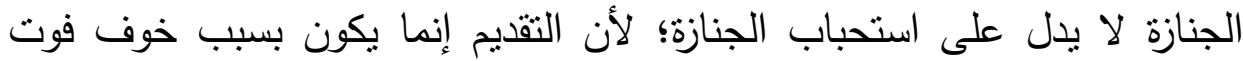

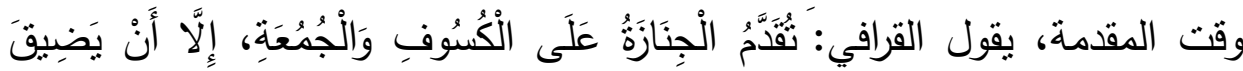

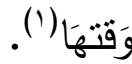

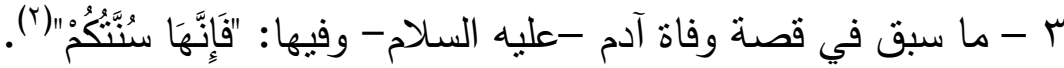

وهو يدل على استحباب صلاة الجنازة وليس فرضيتها(") .

ويجاب على ذلك بما سبق من أن لفظ "السنة" في الحديث معناها: الطريقة،

ويدل لهذا أنه جمع مع التغسيل التكفين والدفن، وهما بلاشك واجبان.

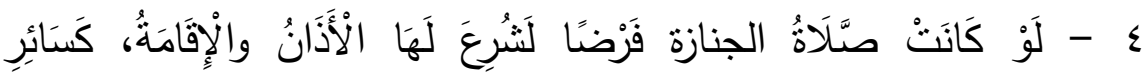

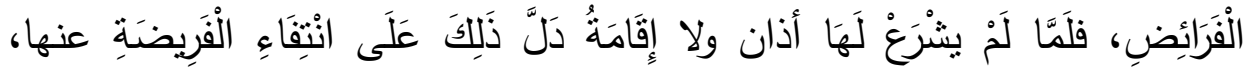

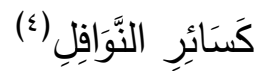

ويمكن أن يجاب عن ذلك: بأنَّ المقصودَ من الأذان الإعلامُ بوقتِ المفروضةِة على الأعيانٍ ، وهذا لا يُوجَذُ في صلاة الجنازة .

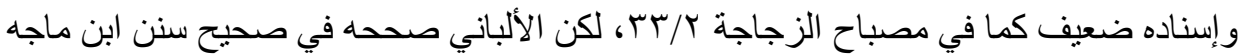

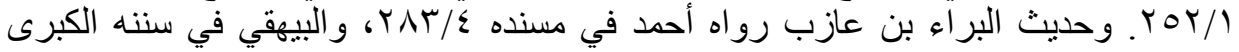

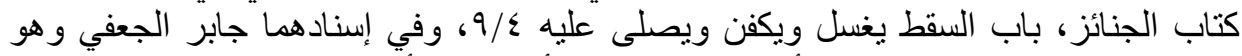

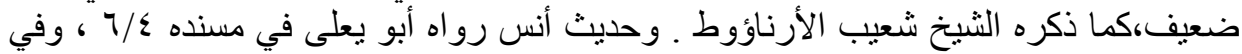

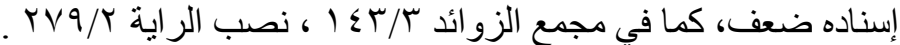

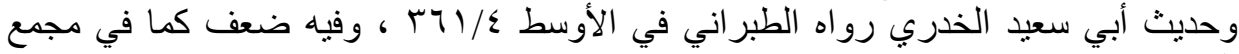

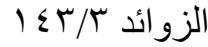

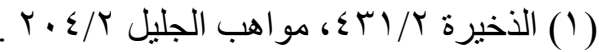

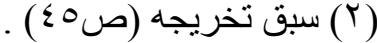

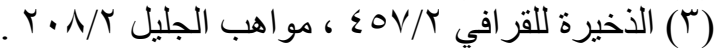

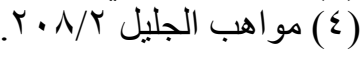

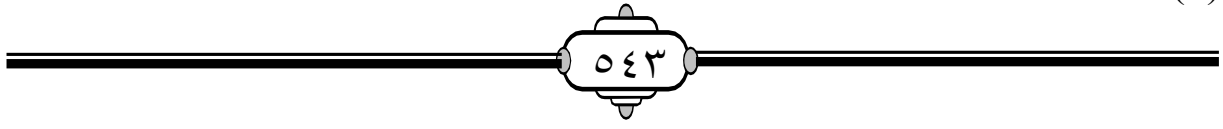


القول الراجح: والراجح مواله أعلم- هو قول أكثر أهل العلم؛ لقوة أدلتهم وسلامتها من المعارضة،، وضعف استخلال المخالفين، وقولهم شاذ مردود لكونه مخالفاً للإجماع، فلا يعول عليه ولا يلتفت إليه كما قال النووي كما سبق .

الفرع الثاني: هل يسقط فرض الكفاية بصلاة الصبي على الجنازة؟ أجمع أهل العلم على أن صلاة الصبي غير المميز غير صحيحة(1) سواء أكانت صلاة مفروضة أم صلاة مسنونة، ومن ثم فإنه لو صلى الجنازة لا يسطط بفعله فرض الكفاية؛ لأنه غير مكلف ولا مخاطب كما سبق ـ وأما الصبي المميز فإنه تصح صلاته وصومه وعبادته؛ لأن له نبة صحيحة كما سبق . ومن العبادات التي تصح منه صلاة الجنازة إذا صلاها مع غيره من المكلفين

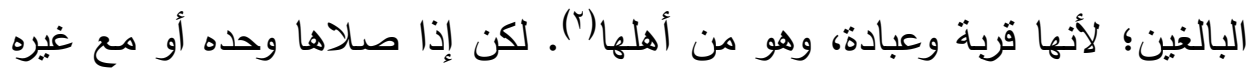

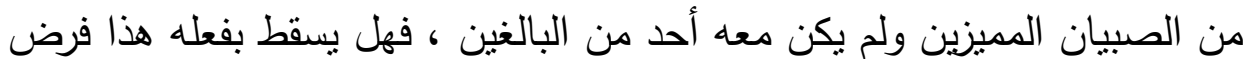

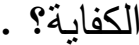

اختلف الفقهاء في ذلك على قولين: القول الأول: إن فرض الكفاية لا بسقط بصلاة الصبي المميز على الجنازة، وإليه ذهب جمهور الفقهاء، ومنهم أكثر

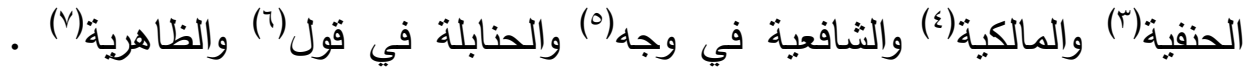
واستخلوا على ذلك بأوجه منها :

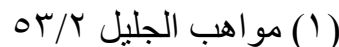

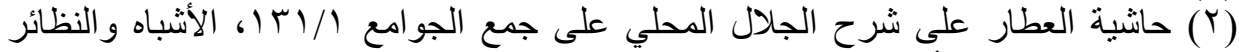

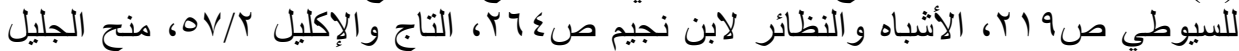

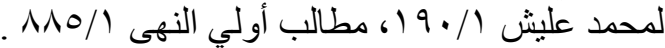

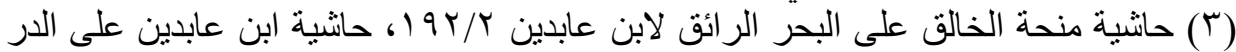

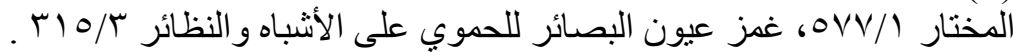

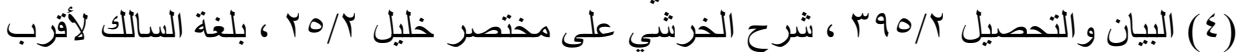

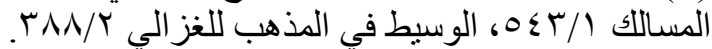

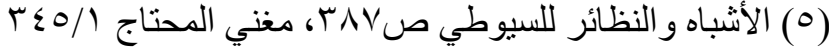

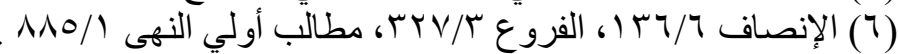

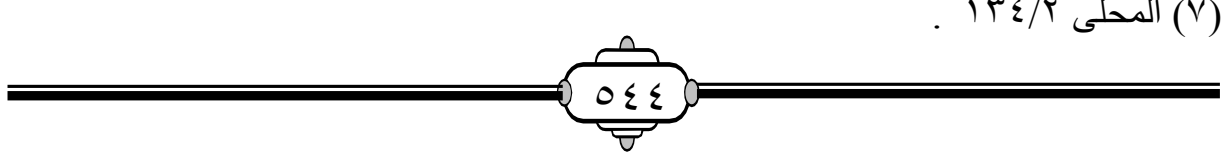




\section{الأول : أن الصبي ليس من أهل الفرض ، وصلاته تقع نافلة(')}

ونوقش هذا: بأن صلاة الصبي وإن كانت نافلة، فإن الواجب المتعين قد

يسقط بالمندوب، كاللمعة المغفلة - المتروكة- في الغسلة الأولى الواجبة في

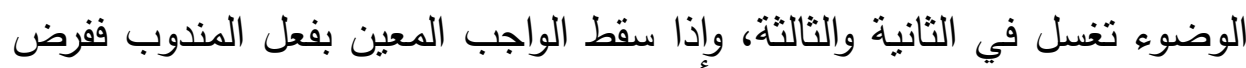

\section{الكفاية أولى (r) - (r)}

الثاني: إن الصبي وإن كان مندوباً إلى فعل الطاعات فلا يؤمن أن يصلي

على غير وضوء أو بغير نية؛ إذ لا حرج عليه في ذلك ، لكونه غير مكلف("). القول الثاني : إن صلاة الجنازة تصح من الصبي المميز ، فلو صلاها دون البالغين سقط بفعله فرض الكفاية، وإليه ذهب الثافعية في الأصح (؛)، والحنابلة في في الصحيح من المذهب(0) وبعض الحنفية كابن عابدين(؟). واستدلوا بالسنة والمعقول:

أما السنة: فحديث عمرو بن سلمة رضي الله عنه السابق، وفيه: "... قال

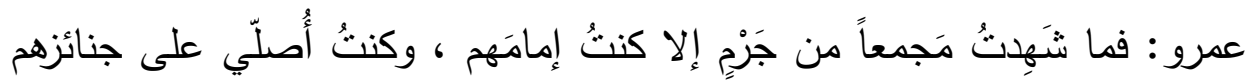
إلى يومي هذا" (V)

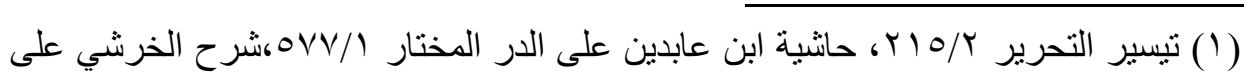

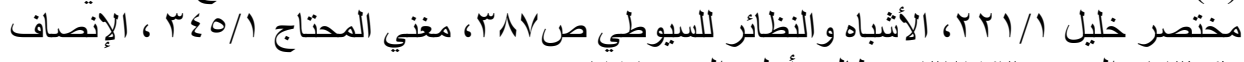

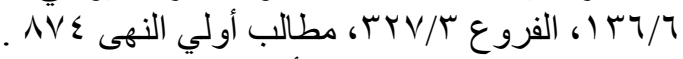

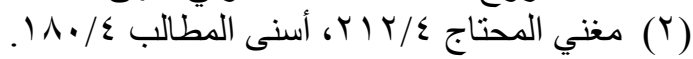

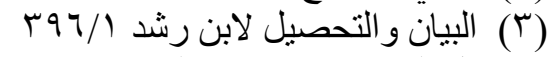

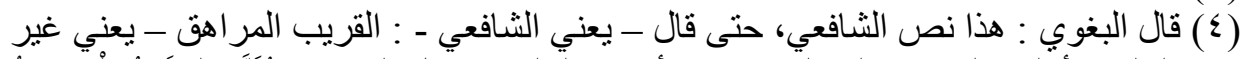

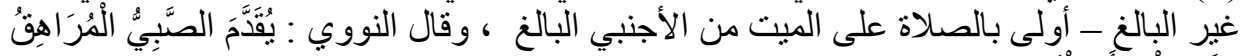

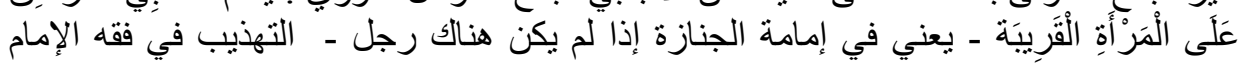

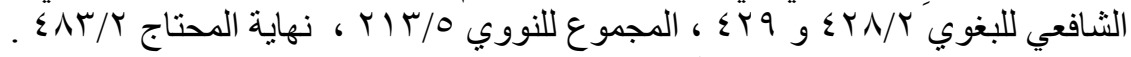

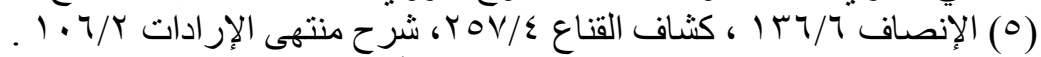

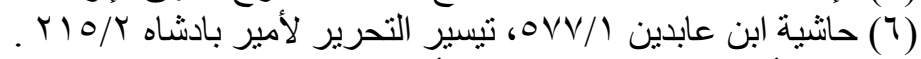

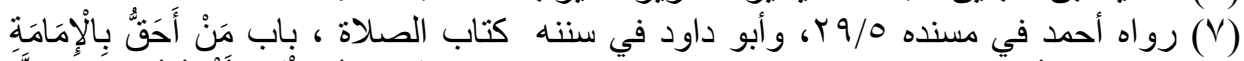

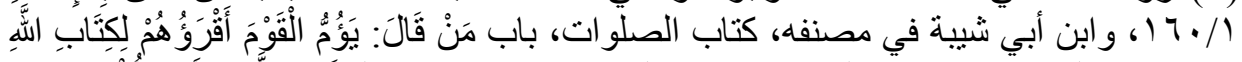

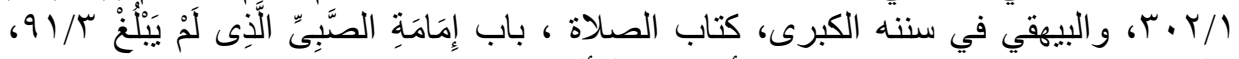

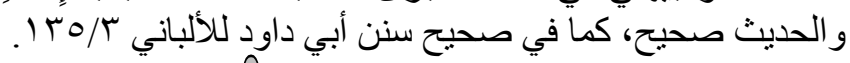

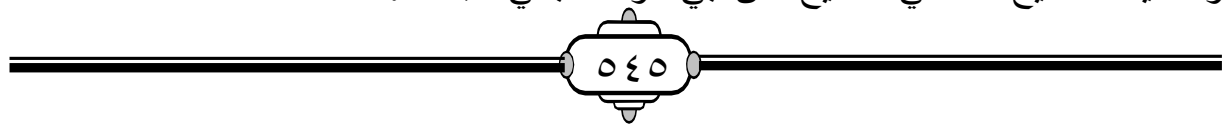




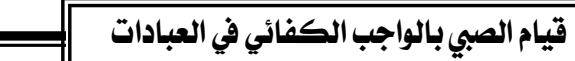

ووجه الدلالة منه: أن عَمْرًا رضي الله عنه كان يصلي وهو صغير دون البلوغ إمامًا بقومه في الفرائض -كما سبق- وفي صلاة الجنازة، وقد وقع ذلك في

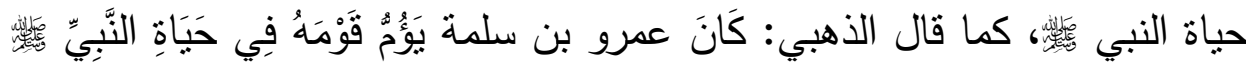
وَهُوَ صَبِيُّ(')، ثم في محضر من الصحابة رضي الله عنهم ولا يعرف لهم مخالف(؟)، فذل ذلك على جواز صلاة الصبي المميز على الجنازة ، ومن ثم بسقط بفعله فرض الكفاية . وأما المعقول: فمن عدة أوجه :

الأول: إن المقصود من صلاة الجنازة الفعل، وقد حصل هذا المقصود، وهو الصلاة على الميت، وقد وجدت(؟). يقول تاج الدين السبكي: فرض الكفاية مهز من من مهمات الوجود، سواء كانت دينية أو دنيوية، قصد الثارع وقوعه، ولم يقصد بالذات عين من يتولاه، ولكن بالفرض؛ إذ لا بد للفعل من فاعل(؛). ونوفش هذا: بأن الفعل وإن لم يُوصف بالوجوب لكنه ورد في الثرع أن

المطلوب فعل موصوف به، وَفعل الصبِي ليس كذلك فلم يتحقق المطلوب(•). ويجاب عن هذا: بأن فعل الصبي وإن لم يقع فرضاً، بل نفلاً، إلا أنه سد مسد الفرض، فإن الواجب قد يسقط بالمندوب(؟) ، كما سبق قريباً. الثاني: إن الصبي المميز من جنس الرجال، وتصح إمامته، فيسقط بصلاته الجنازة فرض الكفاية؛ قياساً على البالغ (`).

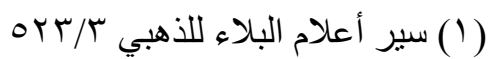

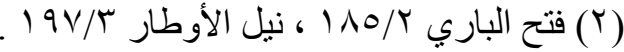

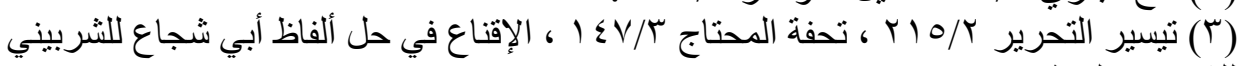

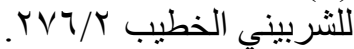

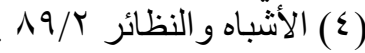

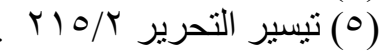

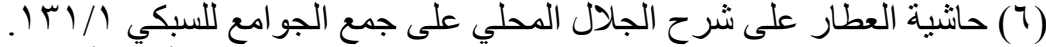

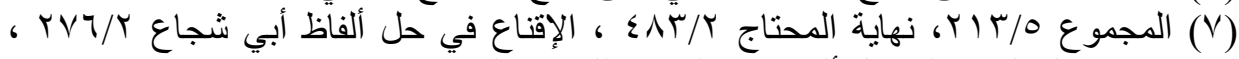

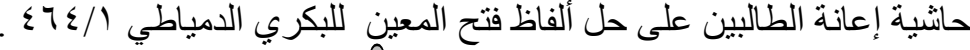




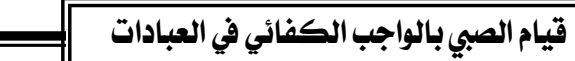

الثالث: إن المقصود من صلاة الجنازة الدعاء، والصبي أقرب إلى إجابة

الدعاء منه، لعدم تلبسه بالمعاصي، فصحت صلاته، وسقوط فرض الكفاية بها('). الرابع: إن الصبي وإن كان ليس أهلاً للوجوب؛ لأنه غير مكلف، لكن ذللك لا ينافي وقوع فعله واجباً، وسقوط الوجوب عن المكلفين بفعله صلاة الجنازة، فان الصبي لو أقر بالثهادتين يقع فرضاً(r)، ولا يلزمه تجديد إقرار آخر بعد البلوغ، حتى على قول من ينفي وجوب الإيمان على الصبي، فصار كالمسافر لا تجب الجمعة عليه، ولو صلاها سقط فرضه (r).

ونوقش هذا: بأنه إن كان الكلام مُسَلَّما به في إسلام الصبي؛ وأنه لا يقع إلا فرضاً، ولا يتتفل به، فلا يسلم به في صلاة الجنازة؛ إذ تقع فرضاً ونفلاً، ولا يقوم النفل فيها مقام الفرض(£)

وأجيب عن هذا: بأن المراد إثبات أنه من أهل أداء الفرض، وقد ثبت ذلك(0).

والراجح كواله أعلم- أن الصبي المميز لو كان قادراً على أداء صلاة

الجنازة، عارفاً بأحكامها وأدعيتها صحت صلاته، وسقط فرض الكفاية بفعله؛ لحديث عمرو بن سلمة رضي الله عنه السابق، ولما ذُكِر من المعقول، وإن كان الأولى قيام بالغ بذلك، خاصة مع اجتماع الناس غالباً في صلاة الجنازة وهذا

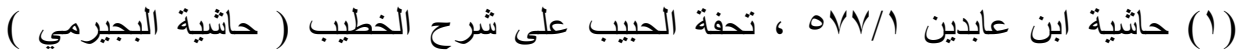

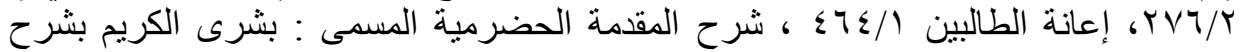

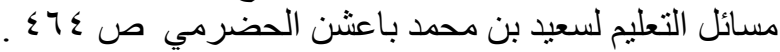

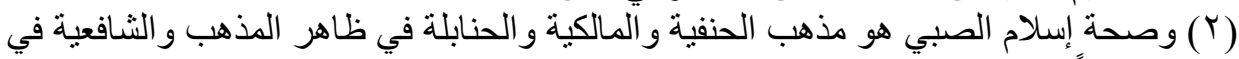

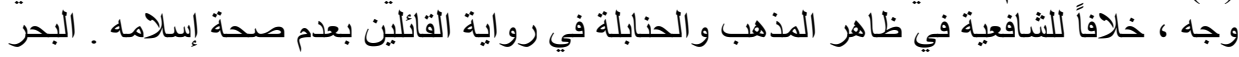

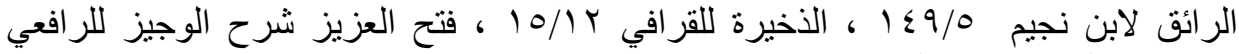

(

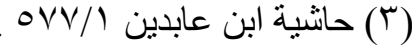

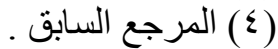

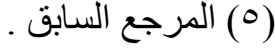

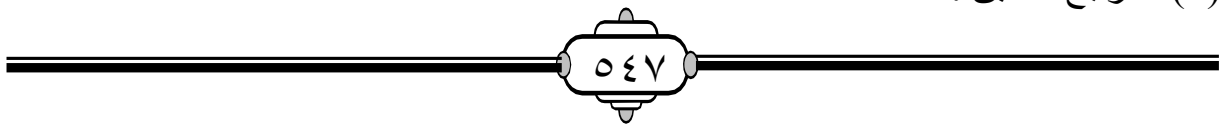




\section{قيام الصبي بالواجب الكفائي في العباداته}

القول يمكن الاحتياج إليه، والعمل به في حال الفتن والحروب والخوف وقلة

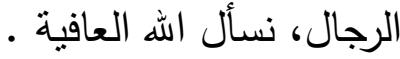

\section{المطلب الثالث: قيام الصبي المميز بتكفين الميت وحمله ودفنه}

أجمع أهل العلم على أن تكفين الميت المسلم، وحمله، ودفنه، فروض على (الى

الكفاية، إذا قام بها من يكفي سقطت عن الباقين (')

واستدلوا على ذلك بأدلة، منها:

1 - حديث الرجل الذي وقصته ناقته بعرفة وهو محرم، وفيه قوله

"وكفنوه في ثثبيه"((). والأمر للوجوب، فإذا قام به من يكفي سقط عن الباقين (r).

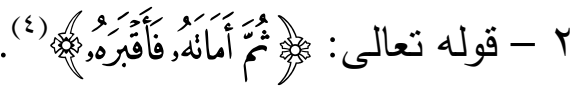

أي جعل الله للإنسان قبراً يوارى فيه؛ إكراماً، وأمر أن يقبر ، ولم يجعله مما يلقى على وجه الأرض تأكله الطيور والوحوش، وهذا سنة باقية في الخلق، فرضاً على الكفاية(0)

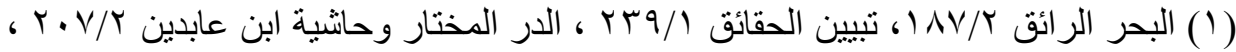

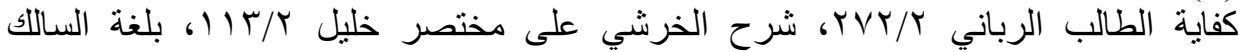

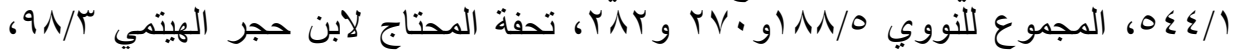

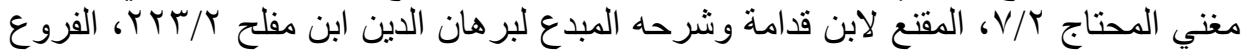

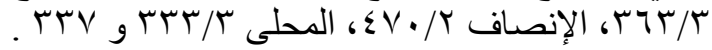

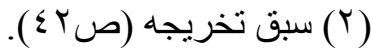

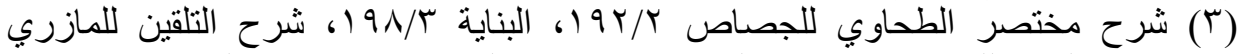

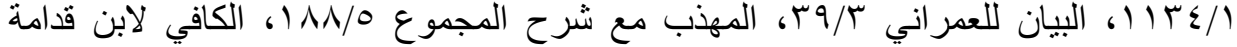

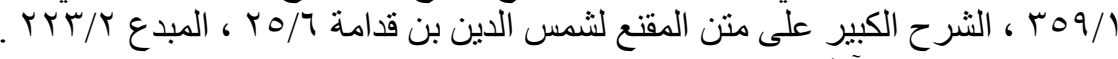

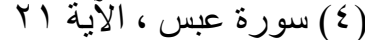

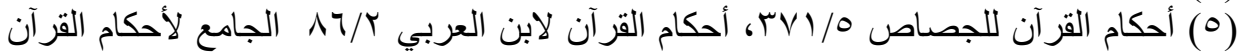

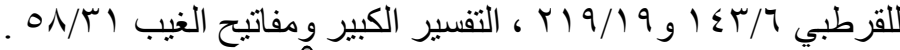




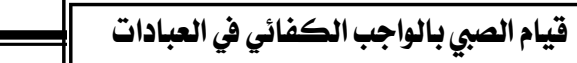

r - إن حمل الميث فرض على الكفاية؛ لأنه وسيلة لدفنه، والوسائل لها

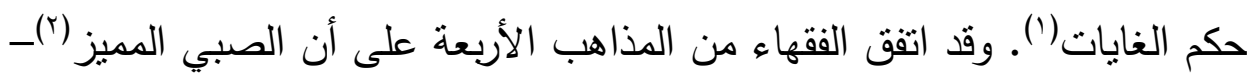
خاصة إذا كان مراهقاً - يجوز أن يقوم بتكفين الميت وحمله ودفنه، ما كان قادراً على ذللك، ويكفي ذللك في سقوط فرض الكفاية، حتى مع وجود البالغين

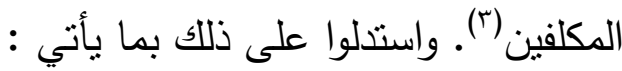

1 - إن كَفْنَ - بسكون الفاء، أي القيام بتكفينه- وحمله ودفنه لا يعتبر فيه

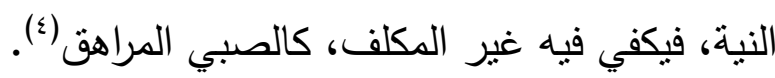
r - إن كَفْنَ - بسكون الفاء - الميت وحمله ودفنه لا يختص فاعلها بكونه

من أهل القربة، فجاز فعلها من غير المكلف، كالكافر والصبي المراهق(م). r - إن تكفين الميت وحمله ودفنه فروض على الكفاية، المقصود منها ستر

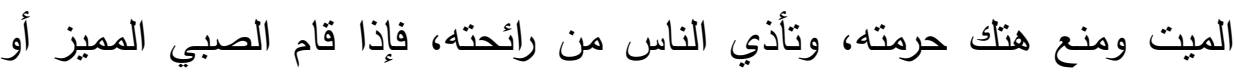
المراهق بذللك - حتى مع وجود البالغين - فقد حصل المقصود ، فيسقط بفعله

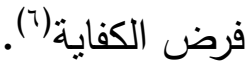
مطلب في : رد الصبي المميز وحده السلامَ دون البالغين

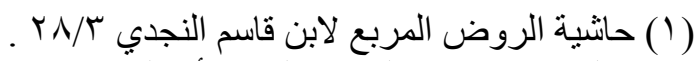

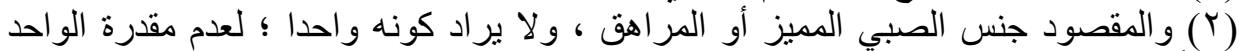

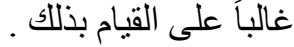

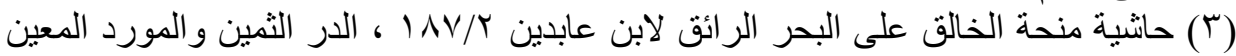

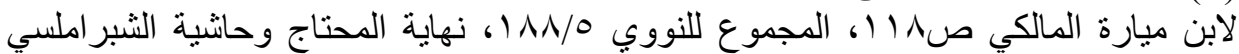

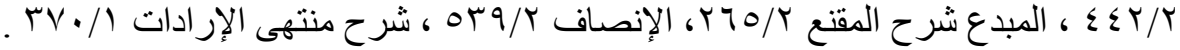

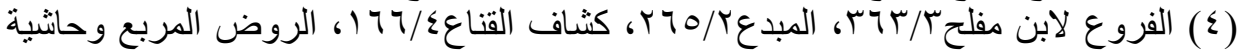

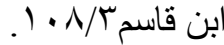

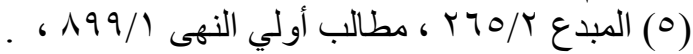

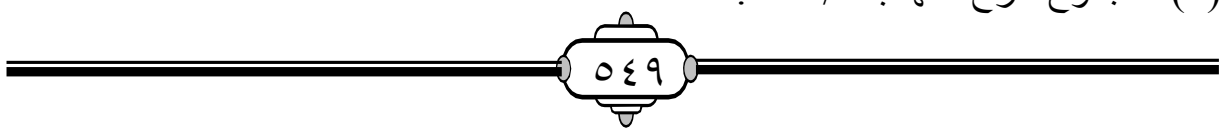


إفثناء السلام من شعائر الإسلام الظاهرة، وهو من مكارم الأخلاق ومعاليها، ومن أسباب التآخي بين المسلمين. وإلقاء السلام سنة على الكفاية، أما رده فقد نقل غير واحد من العلماء الاتفاق على أنه فرض كفاية، إذا قام به البعض سقط عن

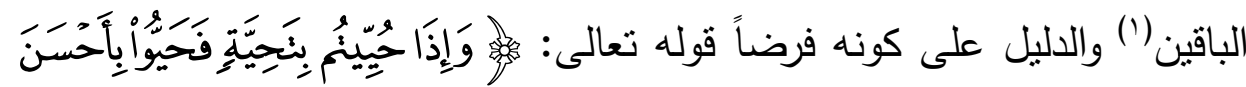

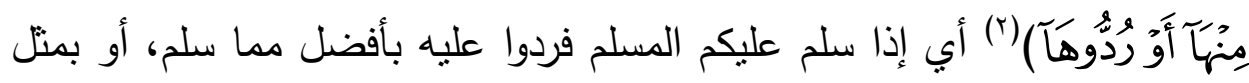
ما سلم، فالزيادة مندوبة، والمماتلة مفروضة"؟َ). والدليل على كونه على الكفاية حديث علي بن أبي طالب رضي الله عنه قال: قال رسول الله الجماعة إذا مروا أن يسلم أحدهم، ويجزئ عن الجلوس أن يرد أحدهمه(؛).لكن ذهب بعض الحنفية كأبي يوسف والطحاوي(0) ، وبعض المالكية(؟) إلى أنه يجب

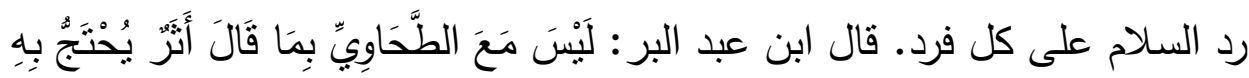

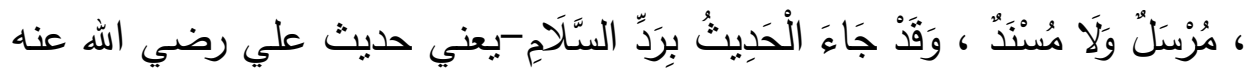

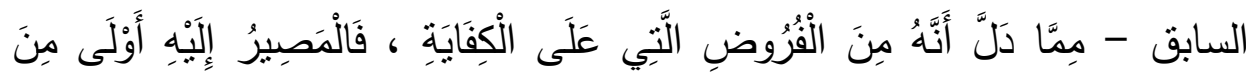

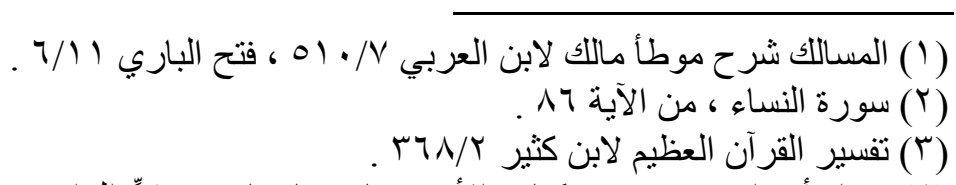

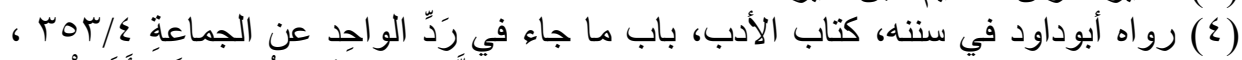

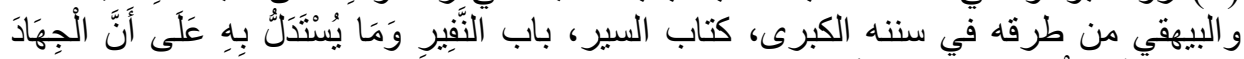

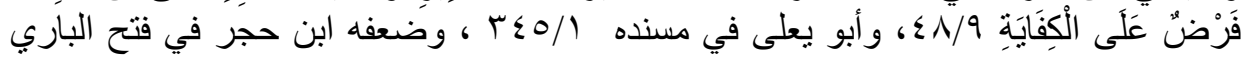

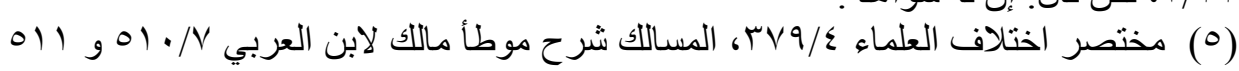

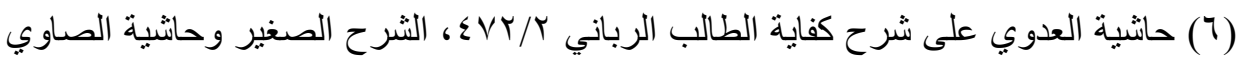

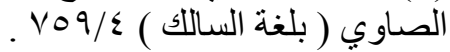

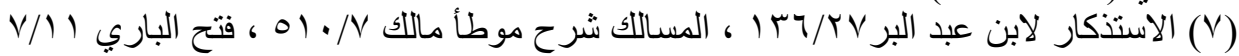

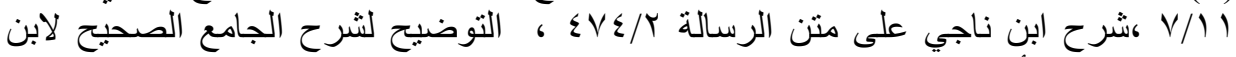

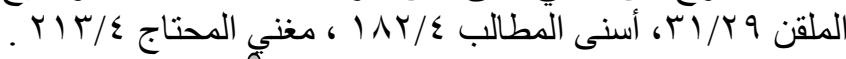


وإذا سلم بالغ على جماعة بالغين فيهم صبي، فرد الصبي، ولم يرد منهم غيره، فهل يسقط عنهم فرض الكفاية؟.

الصبي إما أن يكون مميزاً أو غير مميز، فإن كان غير مميز فلا يسقط

فرض الكفاية برده؛ لأنه ليس من أهل العبادة، فهو كالمجنون('). وأما إن كان مميزاً: فقد اختلف الفقهاء في المسألة على قولين :

القول الأول: إن رد الصبي المميز وحده السلامَ يجزئ ويسقط به فرض

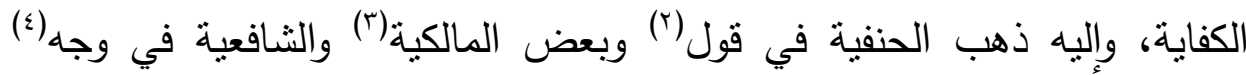
والحنابلة في قول عندهم(ث). وذلك لأن الصبي المميز أهل للعبادة، ومن أهل إقامة الفرض في الجملة،

ولذلك يصح أذانه، وتحل ذبيحته(؟). القول الثاني: إن رد السلام من الصبي وحده دون البالغين لا يكفي في سقوط فرض الكفاية عن البالغين، وإليه ذهب الحنفية في قول(V)، والمالكية في الراجح(^)،

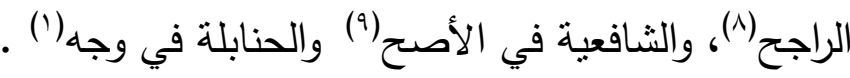

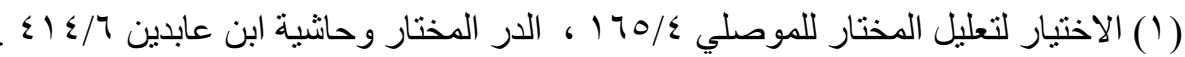

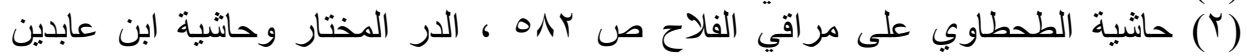
. $\varepsilon 1 \leqslant / 4$

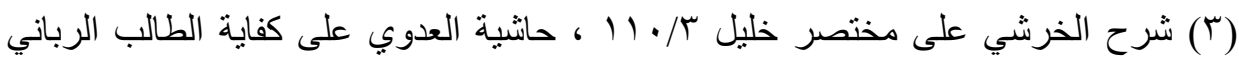
$\varepsilon \vee V \leqslant / T$

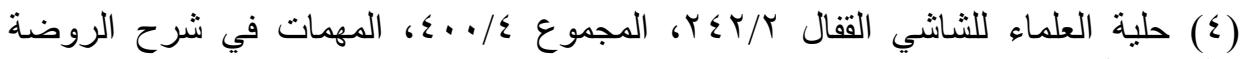

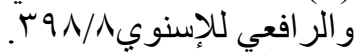

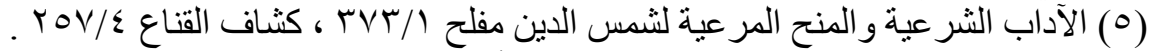

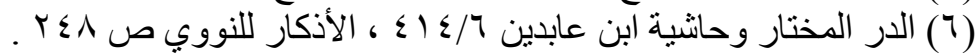

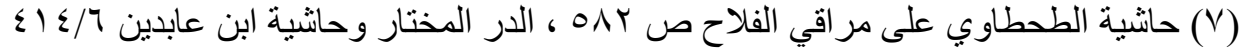

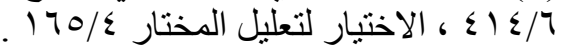

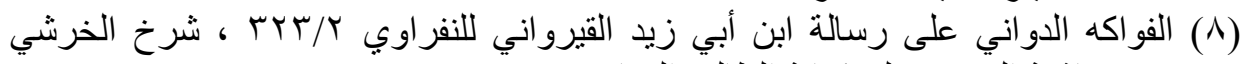

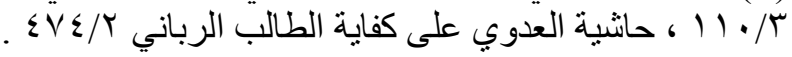

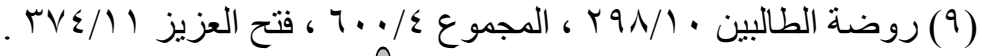




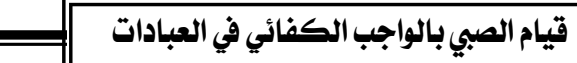

وذلك لأن رد السلام فرض، والصبي المميز ليس من أهل الفرض، فلا يحصل به .

قال بعض الثافعية: فإن قيل: سقط بالصبي المميز فرض الصلاة على

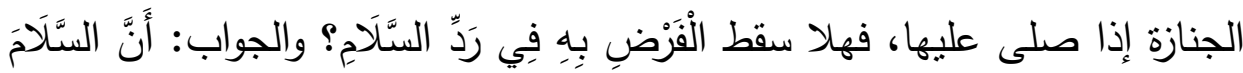

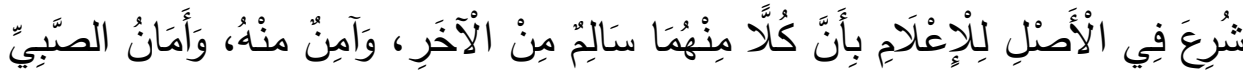

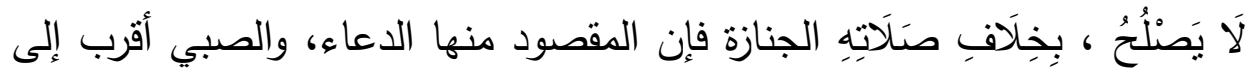

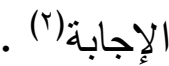

ويمكن أن ينافش هذا: بأن كثيراً من الفقهاء قالوا بصحة أمان الصبي المميز

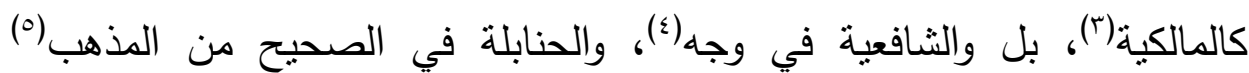
ومحمد بن الحسن من الحنفية(7)، وأيضاً إذا كان الدقصود بصلاة الجنازة الدعاء

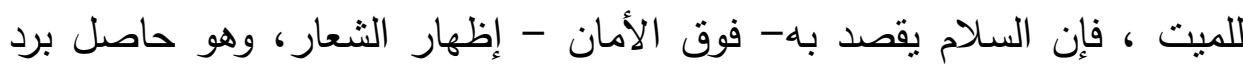

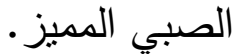

القول الراجح: والراجح واله أعلم - أن رد الصبي للسلام دون البالغين يجزئ ويسقط فرض الكفاية عنهم؛ لأن الصبي من أهل القربة، يصح منه إظهار الثعار كالأذان، وكذللك تصح إمامته في الصلاة، ويجزئ منه تغسيل الميت والصلاة على الصى الصل

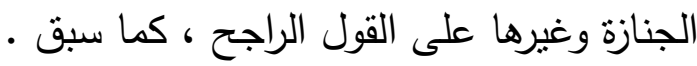

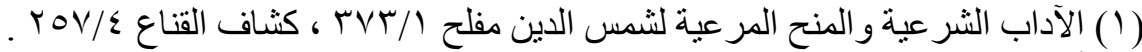

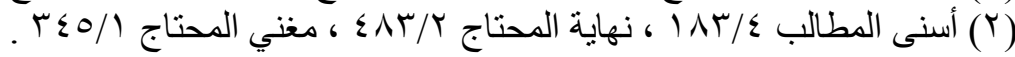

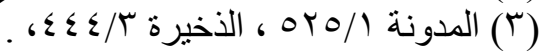

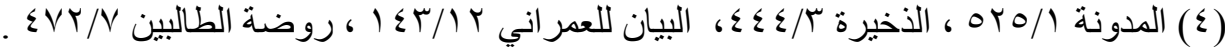

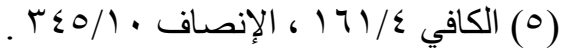

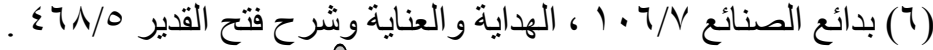




\section{الخاتمة}

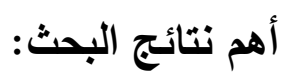

1- أن الصبي لفظ بطلق في اللغة على الذكر والأنثى، ويقال للأنثى أيضاً:

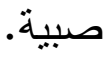

ץ- أن الفقهاء بستعملون لفظ الصبي في كل صغير لم يبلغ الحلم.

r- الراجح واله أعلم أن الصبي المميز هو الذي يفهم الخطاب، ويحسن

الجواب ولا يتحدد بسن معينة، لاختلاف البيئات والمجتمعات، وكذلك اختلاف

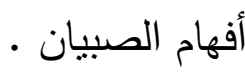

ع - أجمع أهل العلم على أن الصبي غير المميز غير مكلف ولا مخاطب؛

لأنه لا يفهم خطاب التكليف على الوجه المعتبر.

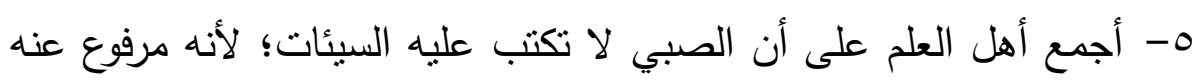

القلم وهو التكليف.

צ- أن الجمهور عرفوا الواجب بأنه: ما يذم تاركه شرعاً على بعض الوجوه،

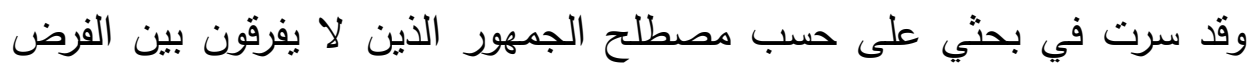

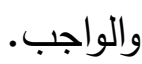

V- أن الواجب له أقسام كثيرة عند الأصوليين وغيرهم، لكن ما بعنيني في بحثي هذا هو أقسامه بحسب فاعله إلى وجب عيني وواجب كنائي الهي.

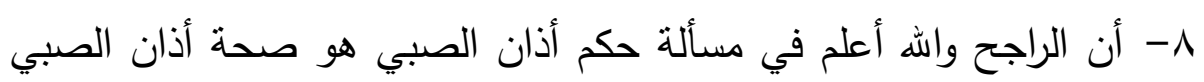

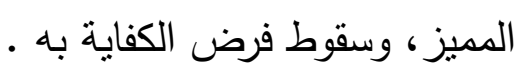

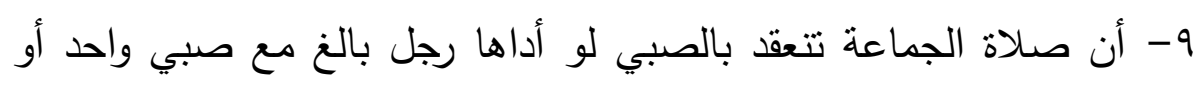

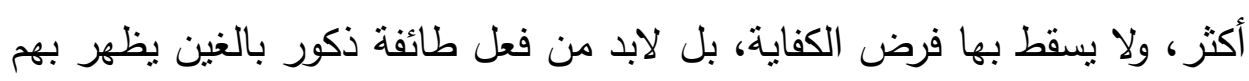

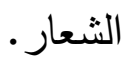

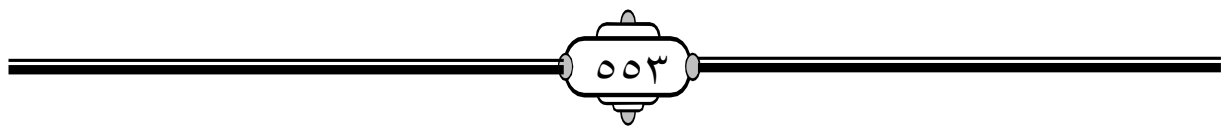




\section{قيام الصبي بالكواجب الكفائي في العباداته}

• 1- الراجح والله أعلم في مسألة إمامة الصبي في صلاة الجماعة، هو صحة

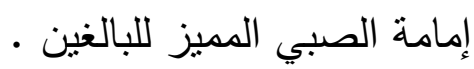

11- أن صلاة العيدين لا تتعقد بالصبي المميز عند الفقهاء الأربعة، ومن ثم ثمانيز

لا يسقط فرض الكفاية بجماعة هو في العدد المتتبر فيها عند كل مذهب.

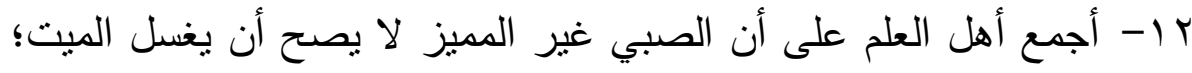

لعدم عقله وتمييزه، أما الصبي المميز فالراجح واله أعلم أنه يصح منه تغسيل

الميت، ويسقط به فرض الكفاية .

rا - أن الصبي المميز إذا كان قادراً على أداء صلاة الجنازة عارفاً بأحكامها

صحت صلاته، وسقط فرض الكفاية بفعله .

ع ا- ان الصبي المميز يصح منه تكفين الميت وحمله ودفنه، ويسقط فرض

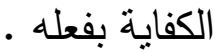

10 - أن رد الصبي للسلام دون البالغين يجزئ ويسط فرض الكفاية فنهم

في الراجح من اقوال الفقهاء ، واله أعلم .

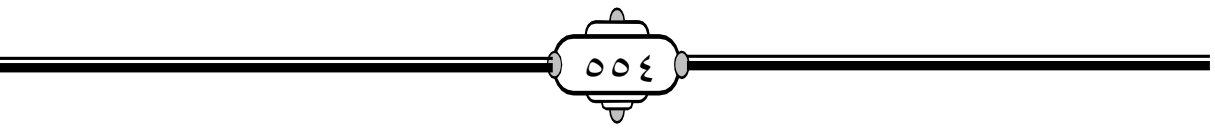




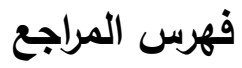

$$
\text { القرآن الكريم. }
$$

ا. الإحسان بترتيب صحيح ابن حبان لابن بلبان، تحقيق: شعيب الأرنؤوط،

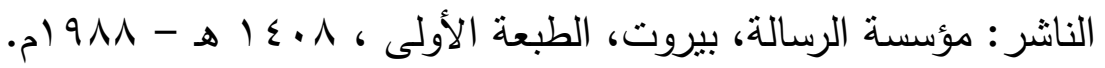
r. أحكام القرآن لابن العربي، تحقيق: محمد عبدالقادر عطا، الناشر: دار الكتب

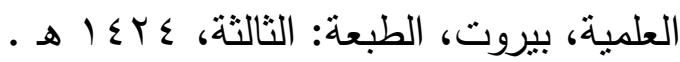
r. أحكام القرآن للجصاص، المحقق: محمد صادق القحاوي، الناشر : دار إحياء

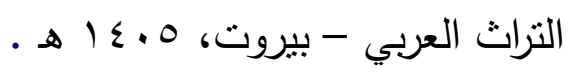

ع. الإحكام في أصول الأحكام للآمدي ، طبعة محمد علي صبيح ، القاهرة. 0. اختلاف الأئمة العلماء لابن هبيرة، المحقق: السيد يوسف أحمد، الناشر : دار

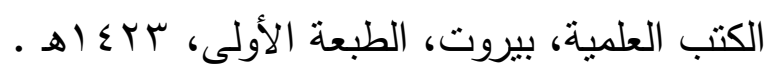
7. الاختيار لتعليل المختار للموصلي ، الناشر: دار الكتب العلمية ببيروت ،

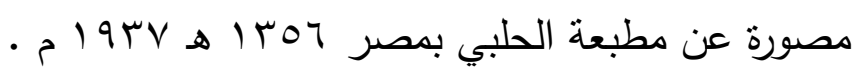
V. الاختيارات الفقهية لابن تيمية، جمع البعلي، تحقيق: أحمد بن محمد حسن

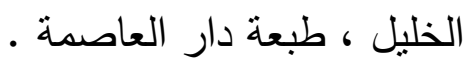
^. إرشاد الساري لشرح صحيح البخاري للقسطلاني، الناشر: المطبعة الكبرى

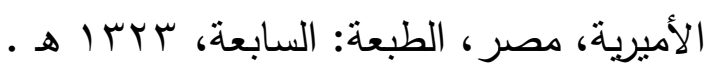
9 9. إرشاد الفحول للشوكاني ، طبعة مصطفى البابي الحلبي، القاهرة. • 1. أسنى المطالب في شرح روض الطالب لزكريا الأنصاري ، الناشر: دار

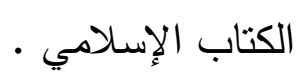

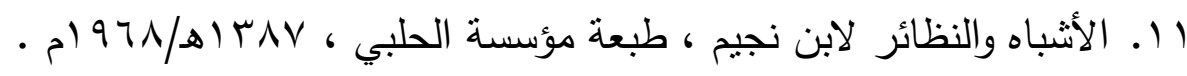

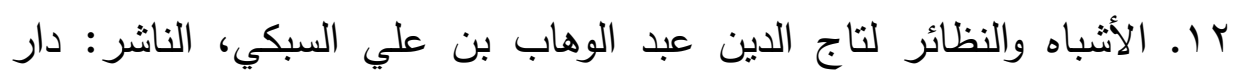

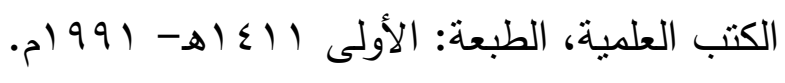

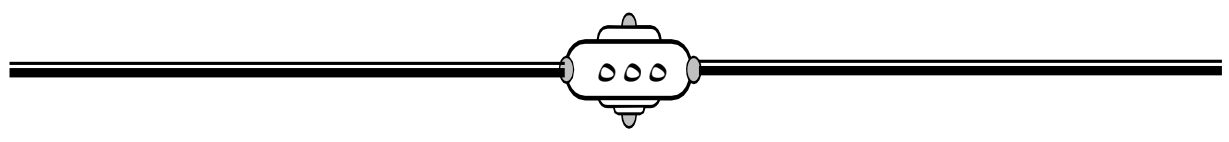




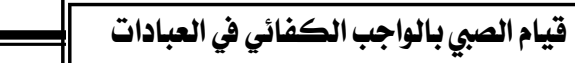

rا. الأشباه والنظائر للسيوطي ، طبعة دار إحياء الكتب العربية، عيسى البابي • الحلبي

ع ا. الإتشراف على مذاهب العلماء لابن المنذر، المحقق: صغير أحمد الأنصاري أبو حماد، الناشر: مكتبة مكة الثقافية، رأس الخيمة، الإمارات العربية

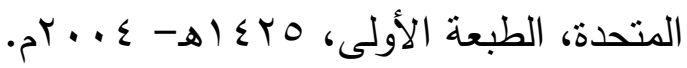

10. الإتشراف على نكت مسائل الخلاف للقاضي عبدالوهاب، المحقق: الحبيب

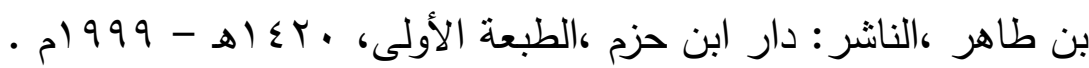

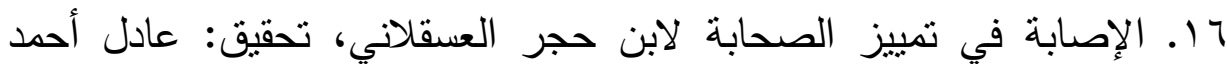
عبد الموجود وعلى محمد معوض، النانشر: دار الكتب العلمية - بيروت ،

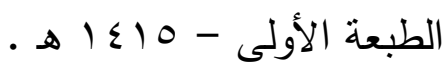

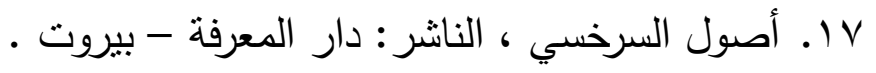

1 1. أصول الفقه لثمس الدين محمد بن مفلح، حققه وعلق عليه وقدم له الدكتور

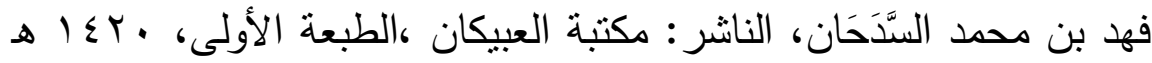

$$
\text { . } 1999-
$$

9 1. إعانة الطالبين على حل ألفاظ فتح المعين للبكري ، طبعة دار الفكر طبعة

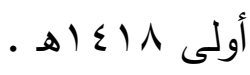

•r. الإقناع في حل ألفاظ أبي شجاع، الدحقق: مكتب البحوث والدراسات - دار ، الفرات

$$
\text { الفكر ، الناشر : دار الفكر - بيروت . }
$$

r. إكمال المعلم بفوائد مسلم للقاضي عياض ، الناشر : دار الوفاء ، مصر

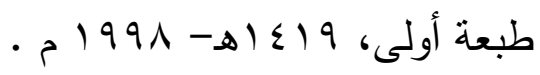

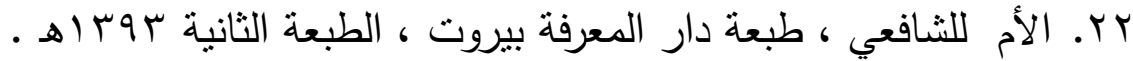

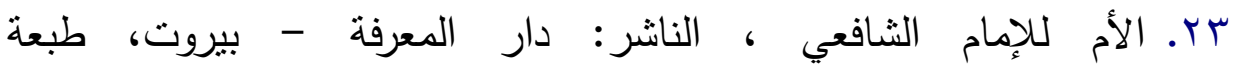
. $199 \cdot / 81 \leqslant 1$.

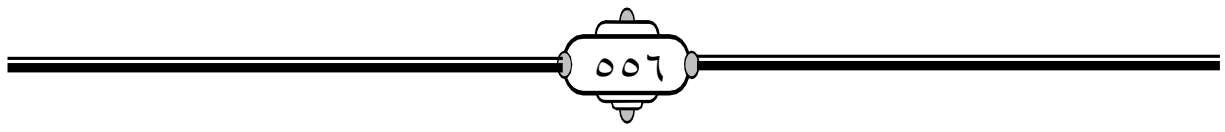




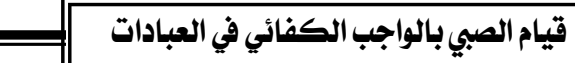

צr. الإنصاف في معرفة الراجح من الخلاف لعلاء الدين المرداوي، تحقيق: الدكتور عبد اله بن عبدالمحسن التركي- الدكتور عبد الفتاح، محمد الحلو، النانر: هجر للطباعة والنشر والتوزيع بالقاهرة - جمهورية مصر العربية

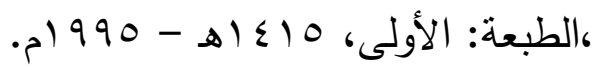

هr. الإنصاف في معرفة الراجح من الخلاف لعلاء الدين المرداوي، طبعة دار

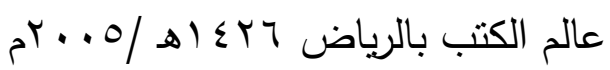

جr. الأوسط في السنن والإجماع والاختلاف لابن المنذر، تحقيق: أبو حماد صغير أحمد بن محمد حنيف، الناشر: دار طيبة - الرياض - السعودية،

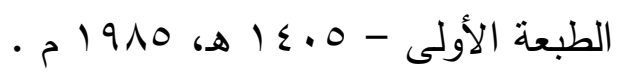

، rV

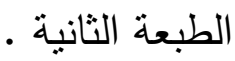

^ץ. بحر المذهب للروياني، المحقق: طارق فتحي السيد، الناشر: دار الكتب العلمية، الطبعة الأولى، 9 . - بץ.

qr. بداية المجتهد ونهاية المقتصد لابن رشد الحفيد، الناشر : مطبعة مصطفى الافى

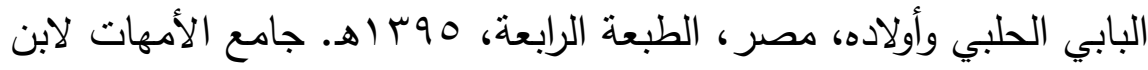

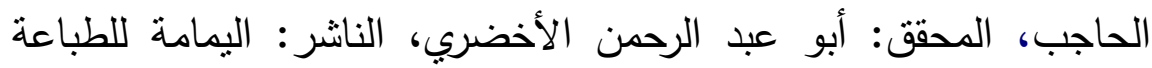

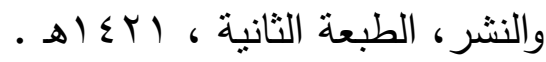
• r. بدائع الصنائع في ترتيب الثرائع للكاساني، الناشر : دار الكتب العلمية،

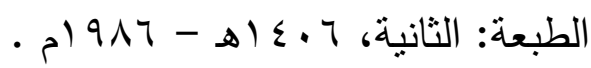
آس. البدر المنير في تخريج الأحاديث والآثار الواقعة في الثرح الكبير لابن الملقن المحقق: مصطفى أبو الغيط وعبد الله بن سليمان وياسر بن كمال ـ النانر : دار الهجرة للنشر والتوزيع - الرياض-السعودية - الطبعة: الاولى، . 5 r..

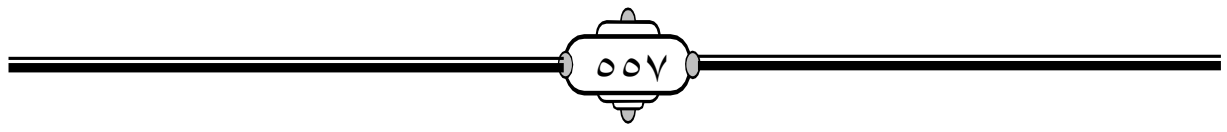




\section{قاميام الصبي بالواجب الكفائي في العباداته}

rr. بلغة السالك لأقرب المسالك (حانية الصاوي على الثرح الصغير)، الناشر: دار المعارف - مصر •

rس. البناية شرح الهداية للعيني ، الناشر : دار الكتب العلمية - بيروت، لبنان ،

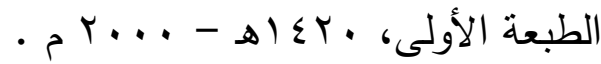

ع r. البيان في مذهب الإمام الثافعي للعمراني ، المحقق: قاسم محمد النوري ،

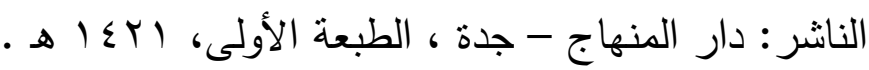

هץ. البيان والتحصيل لابن رشد ( الجد ) ، حققه: د محمد حجي وآخرون ،

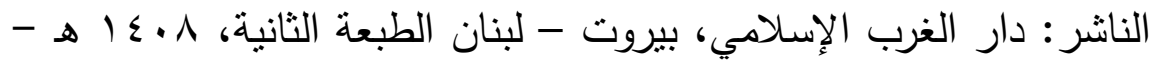
$\cdot 1911$

بr. التاج والإكليل لمختصر خليل، مطبوع مع مختصر خليل ومواهب الجليل ،

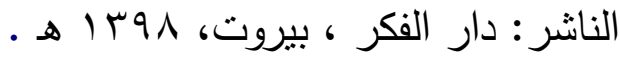

VV Vاريخ دمشق لابن عساكر ، المحقق: عمرو بن غرامة العمروي، الناشر : دار

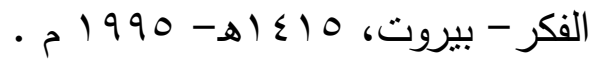

^r. التبصرة للخمي، دراسة وتحقيق: الدكتور أحمد عبد الكريم نجيب ، النانثر:

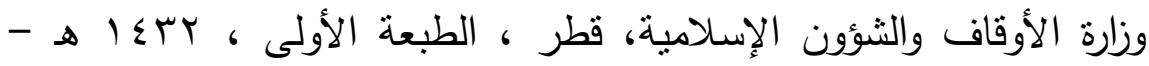
$\cdot{ }^{3}+11$

qr. تبيين الحقائق شرح كنز الدقائق للزيلعي، الناشر : دار الكتاب الإسلامي ،

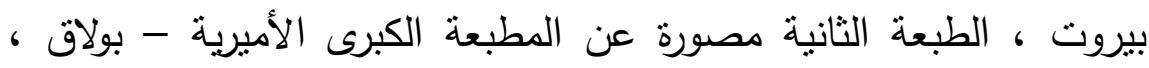

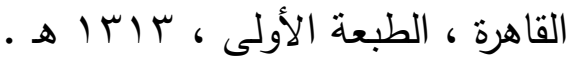
•ــ التجريد للقدوري، المحقق: مركز الدراسات الفقهية والاقتصادية، د /محمد الأه

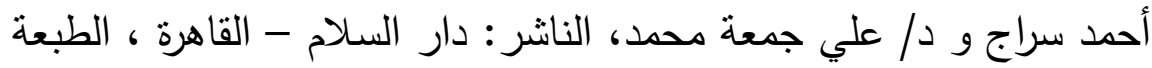

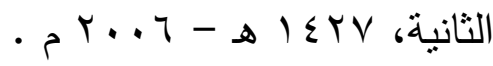

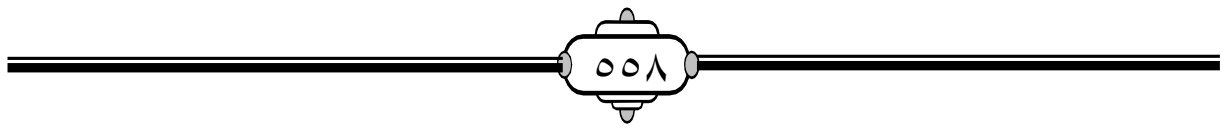




\section{قبيام الصبي بالواجب الكفائي في العباداته}

اءـ. تحبير مختصر خليل لبهام ، المحقق: د. أحمد عبد الكريم نجيب و د. حافظ عبد الرحمن خير ، الناشر : مركز نجييويه للمخطوطات وخدمة التزاث

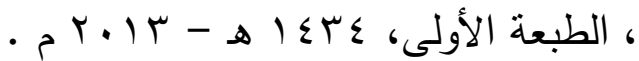

rع. تحرير ألفاظ التتبيه للنووي، الناشر : دار القلم - دمشق - الطبعة الأولى ، الهى . ه 1 . 1

rاء. تحفة الحبيب على شرح الخطيب لسليمان البجيرمي (حاثية البجيرمي)، الناشر: دار الفكر، طبعة 10 إهـ - 990 ام .

§ §. تحفة المحتاج في شرح المنهاج لابن حجر الهيتمي الناشر: دار إحياء

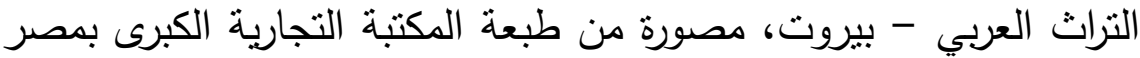

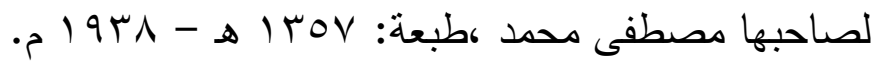
0ـ. تحفة المودود بأحكام المولود لابن القيم الجوزية ، طبعة مطبعة الددني

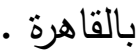

7ــ. التعليق الكبير في المسائل الخلافية بين الأئمة لأبي يعلى الفراء، المحقق: محمد بن فهذ بن عبدالعزيز الفريح، الناشر: دار النوادر، دمشق - سوريا، لانيا،

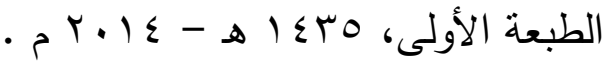

VV V. التفسير الكبير ومفاتيح الغيب للفخر الرازي ، النانر: دار إحياء التراث

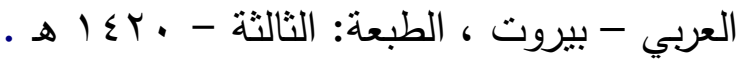

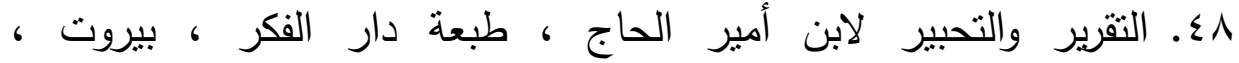
- ماله

9ء. تقويم الأدلة لأبي زيد الدبوسي، المحقق: خليل محيي الدين الميس، الناشر:

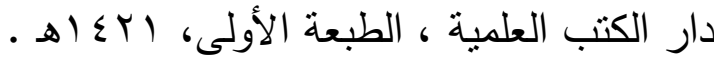
•0. التلخيص الحبير في تخريج أحاديث الرافعي الكبير لابن حجر ، طبعة دار الهار

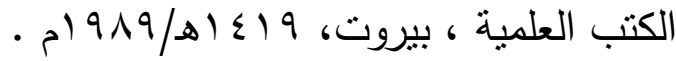

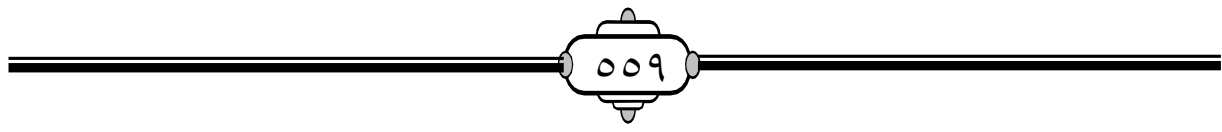




\section{قيام الصبي بالواجب الكفائي في العباداته}

10. التمهيد في تخريج الفروع على الأصول للإسنوي، المحقق: محمد حسن

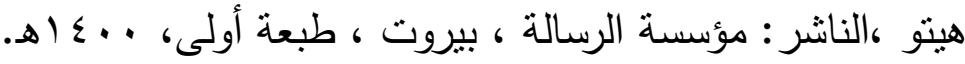

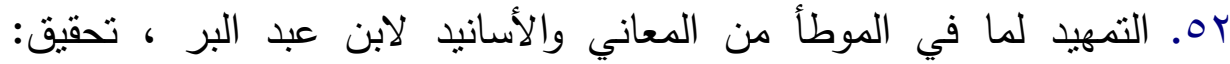

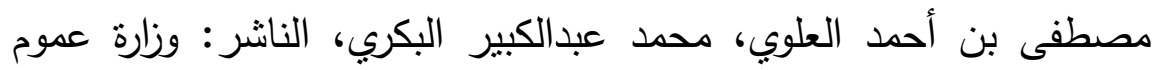

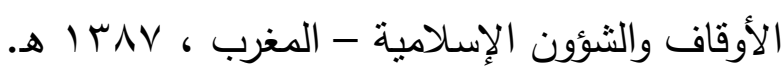

rه. التتبيه على مبادئ التوجيه لعبد الصمد بن بشير التتوخي ، المحقق: الدكتور

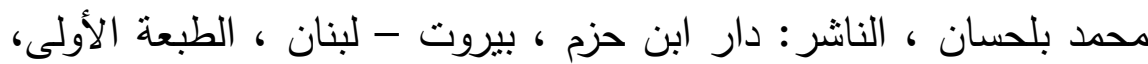

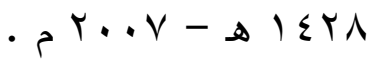

§o. تنقيح التحقيق لابن عبد الهادي، تحقيق: سامي بن محمد بن جاد الله وعبد العزيز بن ناصر الخباني، دار النشر: أضواء السلف - الرياض، الطبعة

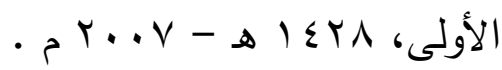

00. تهذيب اللغة لمحمد بن أحمد الأزهري الهروي، الناشر: دار إحياء التراث

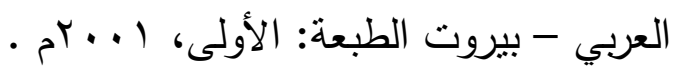

1. التهذيب في فقه الإمام الثافعي للبغوي، الححقق: عادل أحمد عبد الموجود،

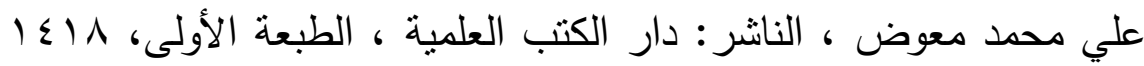

$$
\text { . } 199 \mathrm{~V}-\mathrm{s}
$$

OV المحقق: د. أحمد بن عبدالكريم نجيب، الناشر : مركز نجييويه للمخطوطات

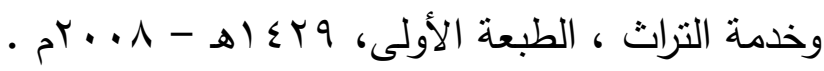

هـ. التوضيح لثرح الجامع الصحيح لابن الملقن، الناشر : دار النوادر ، دمشق -

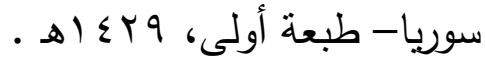

09. تيسبر التحرير لأمير بادشاه ، الناشر: مصطفى البابي الْحلَبِي بمصر -

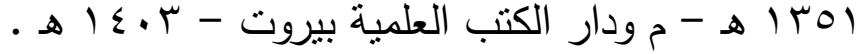

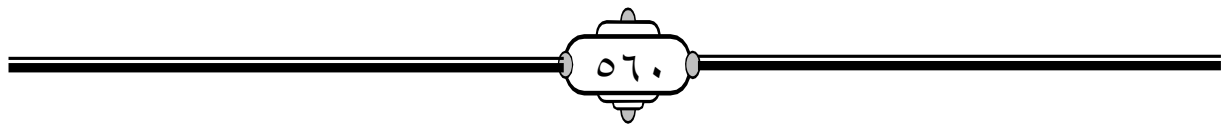


• 7 . جامع أحكام الصغار للأستروشني، طبعة دار الفضيلة . آT. الجامع الصغير في أحاديث البشير النذير للسيوطي ، الناشر : دار الكتب

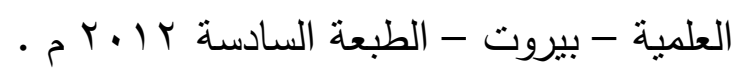

ז 7. الجامع المسند الصحيح (صحيح البخاري) المحقق: محمد زهير الناصر،

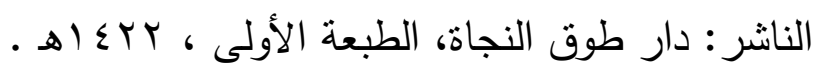

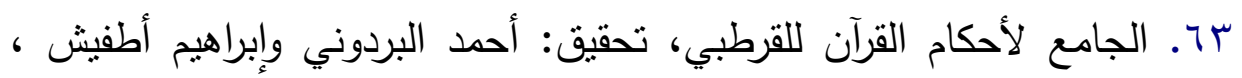

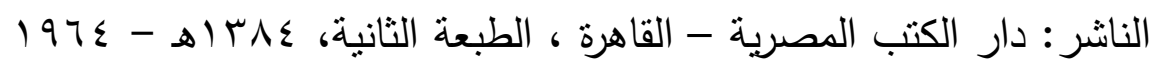

ع ا. الجوهرة النيرة للحدادي ، الناشر: المطبعة الخيرية ، الطبعة الأولى، .

7 . حاشية ابن قائد النجدي على منتهى الارادات، المحقق: د.عبداله بن

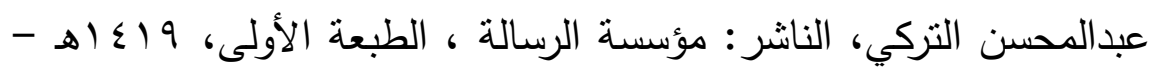

$$
\text { - } 1999
$$

77. حاشية الخلوتي على منتهى الإرادات، تحقيق: مجموعة من الباحثين،

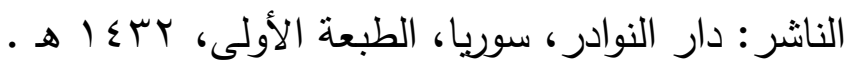

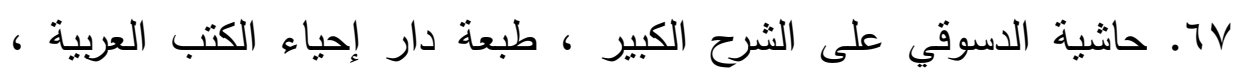
عيسى البابي الحلبي بمصر • 1 7. حاشية الدسوقي على الثرح الكبير للاردير ، الناشر: دار الفكر • 79. حاشية الرملي على أسنى المطالب ، طبعة دار الكتب العلمية بيروت ،

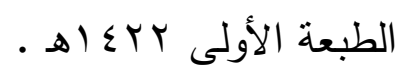

• . حاشية الثبراملسي على نهاية المحتاج للرملي ، طبعة مصطفى البابي الحلبي،

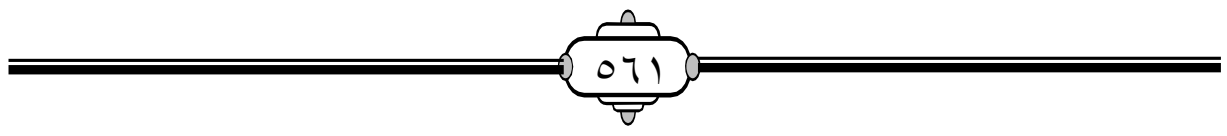




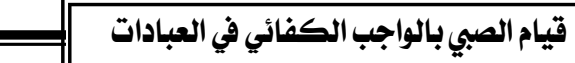

اV. حاثية الثربيني على الغرر البهية لزكريا الأنصاري ، الناشر: المطبعة

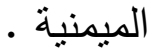

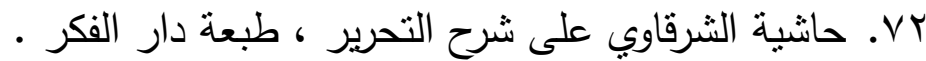
rr. حانشية الطحطاوي على مراقي الفلاح ،الدحقق: محمد عبد العزيز الخالدي

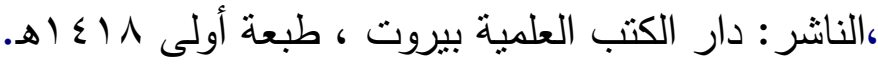
ع V. حاثشية العدوي على كفاية الطالب الرباني لرسالة ابن أبي زيد القيرواني

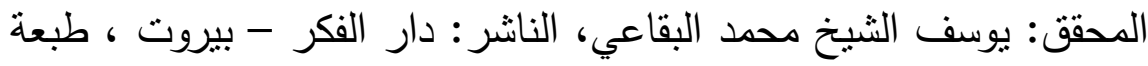

$$
\text { - } 1998-ه \mid \leq 1 \leq:
$$

V0. حاثشية عبدالرحمن بن قاسم النجدي على الروض المربع ، مطبوع مع

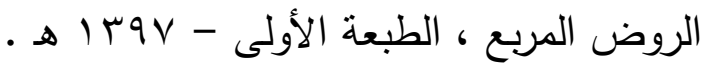
VT. حاشية منحة الخالق لابن عابدين على البحر الرائق، مطبوع مع البحر الإكر الرائق، الناشر : دار الكتاب الإسلامي ، الطبعة الثانية . VV أحمد عبد الموجود ، الناشر : دار الكتب العلمية، بيروت - لبنان ، الطبعة الهية

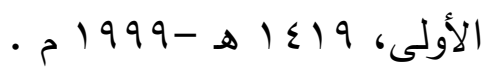

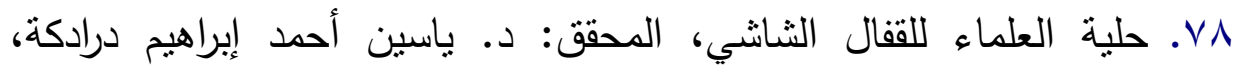

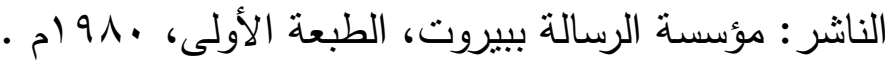

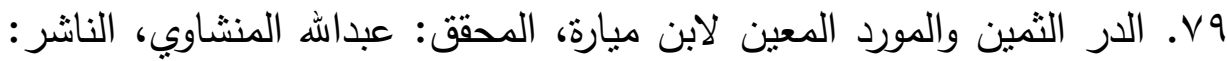

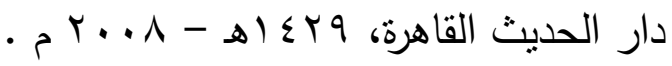

.A. درر الحكام في شرح مجلة الأحكام لعلي حيدر ، الناشر: دار الجيل -

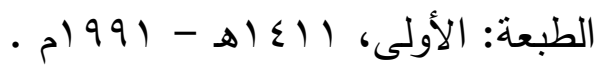

1... رد المحتار على الدر المختار (حانية ابن عابدين ) ، الناشر: دار الفكر -

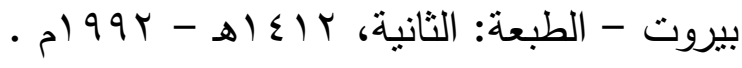

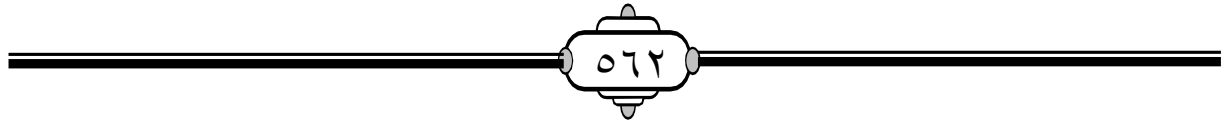




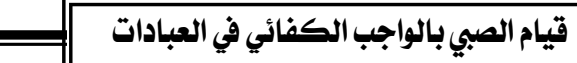

r r. رفع الحاجب عن مختصر ابن الحاجب لتاج الدين بن السبكي، الدحقق:

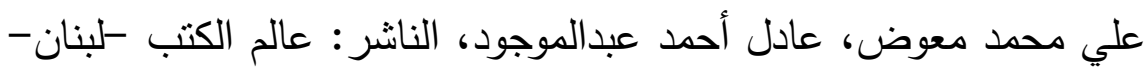

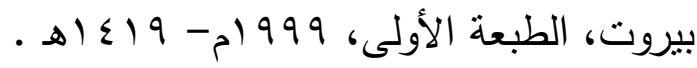

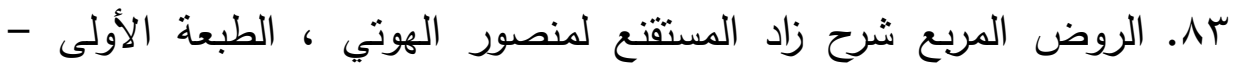

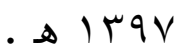

عـ. روضة المستبين في شرح كتاب التلقين لابن بَزيزِة، المحقق: عبد اللطيف

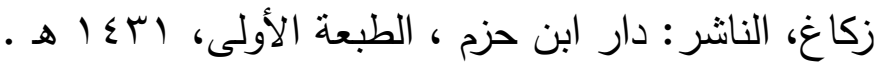

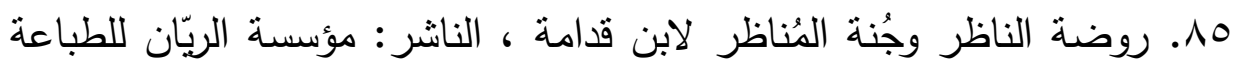

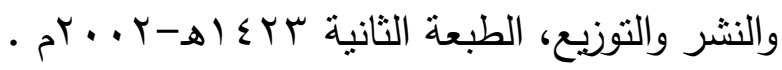

41. الزاهر في معاني كلمات الناس لابن الأنباري ، تحقيق د/حانم صالح

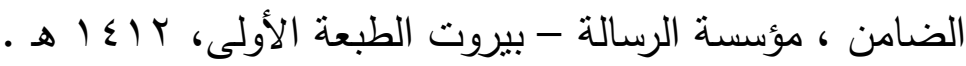
AV

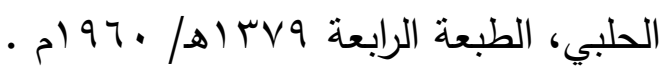

11. سنن أبي داود المحقق: محمد محيي الدين عبد الحميد - الناشر : المكتبة

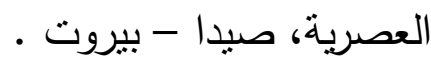

19. سنن ابن ماجه ، طبعة دار الفكر .

•9. سنن الترمذي، الناشر مكنبة ومطبعة مصطفى البابي الحلبي ، مصر ،

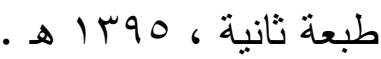

و 91 ـ سنن الدارقطني ، طبعة عالم الكتب بيروت .

r9. السنن الكبرى للبيهقي، الناشر : مجلس دائرة المعارف، حيدر أباد الدكن -

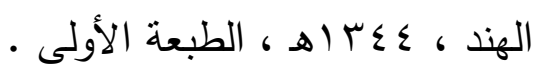

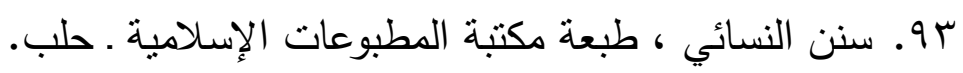

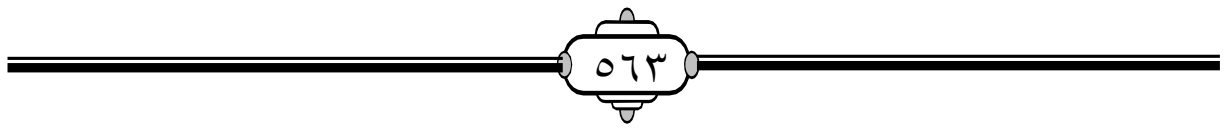




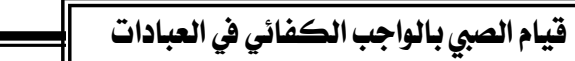

؟ 9. سير أعلام النبلاء للذهبي، الدحقق: شعيب الأرناؤوط، الناشر: مؤسسة

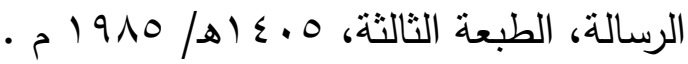

9. الثنامل في فقه الإمام مالك لبهرام المالكي ، ضبطه وصححه: أحمد بن

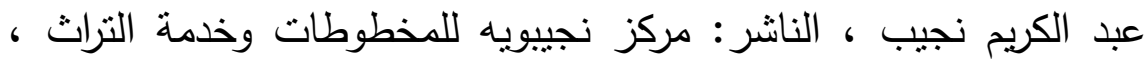

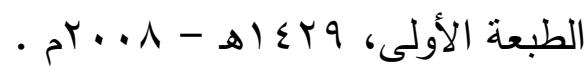

97. شرح ابن ناجي التتوخي على منن الرسالة، تحقيق: أحمد فريد المزيدي ،

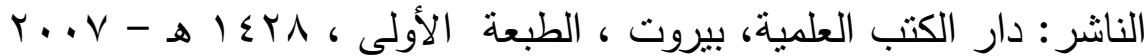

9V. شرح التلقين للمازري، المحقق: سماحة الثيخ محمَّد المختار السّلامي،

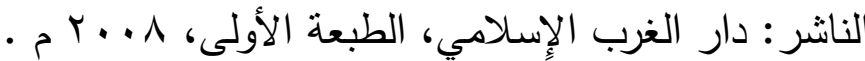

91. شرح الخرشي على مختصر خليل ، الناشر : دار الفكر للطباعة - بيروت. 99 9. شرح الزُرقاني على مختصر خليل، تحقيق: عبد السلام محمد أمين ،

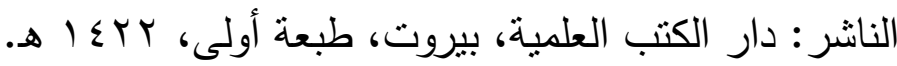
. . . شرح الزركثي على مختصر الخرقي، تحقيق: عبدالمنعم خليل إبراهيم،

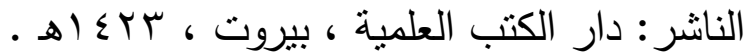

1. ا. الثرح الكبير على متن المقنع لشمس الدين بن قدامة تحقيق: الدكتور

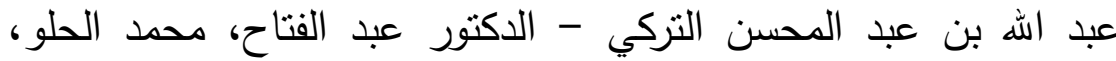
الناشر: هجر للطباعة والنشر والتوزيع بالقاهرة - جمهورية مصر العربية

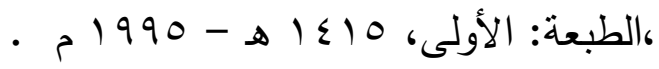
ז • ا. الثرح الكبير على مختصر خليل للاردير ، النانشر: دار الفكر . r. 1. شرح الكوكب المنير لابن النجار ، طبعة مكتبة العبيكان ـ الرياض .

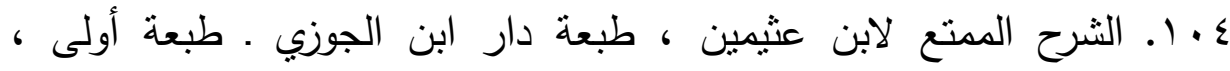
- ه $\leqslant Y Y$

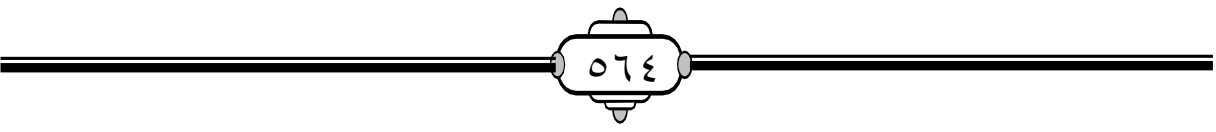




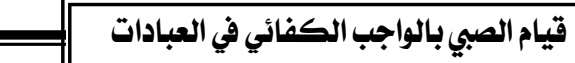

ه ـ ا. شرح جلال الدين المحلي على جمع الجوامع وحاشية العطار ، الناشر: دار الكتب العلمية . - مات

4 ـ ا ـ شرح زروق على متن الرسالة، الناشر : دار الكتب العلمية، بيروت - لبنان

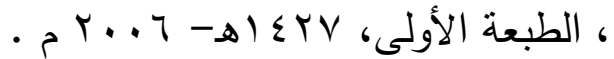

V. 1. شرح فتح القدير للكمال بن الهمام ، الناشر: دار الفكر •

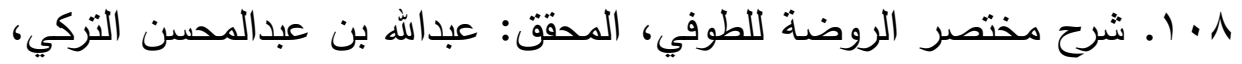

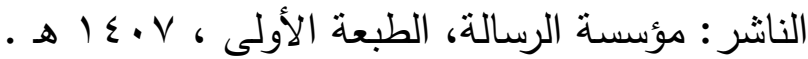
9.1. شرح مشكاة المصابيح للطيبي ،المحقق: عبد الحميد هنداوي ،الناشر:

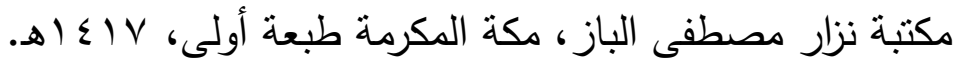
•11. شرح مشكل الآثار للطحاوي، تحقيق: شعيب الأرنؤوط، النانشر: مؤسسة النار،

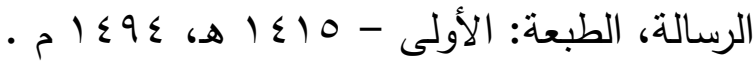
111. شرح منتهى الإرادات للبهوتي، الناشر : عالم الكتب، الطبعة الأولى،

$$
\text { • }
$$

r Iا ـ شعب الإيمان للبيهقي، النانشر: دار الكتب العلمية، بيروت، الطبعة الأولى • إ اهـ، تحقيق: محمد السعيد بسيوني زغلول . بالا. الصحاح تاج اللغة لإسماعيل بن حماد الجوهري ، طبعة دار العلم

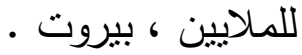

ع ا (1 . صحيح ابن حبان بترتيب ابن بلبان ، طبعة مؤسسة الرسالة . 110 11 . صحيح ابن خزيمة، تحقيق: الدكتور محمد مصطفى الأعظمي، الناشر :

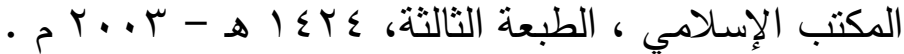
117 ا ـ صحيح مسلم المحقق: محمد فؤاد عبد الباقي ، الناشر : دار إحياء التزاث

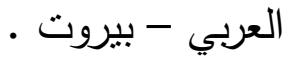

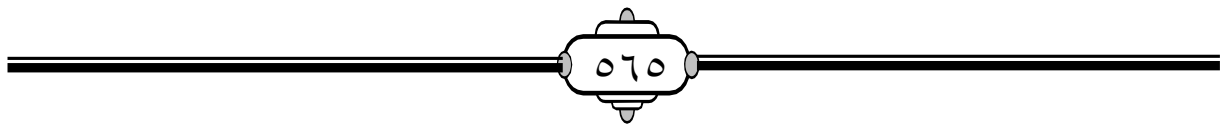


VIII V عجالة المحتاج إلى توجيه المنهاج لابن الملقن، تحقيق: عز الدين هشام

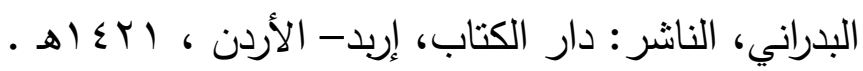

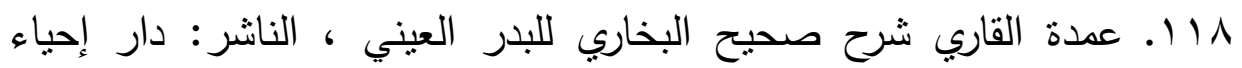

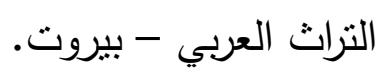

111.ـ العناية شرح الهاية للبابرتي، مطبوع مع الهاية وشرح فتح القدير ،

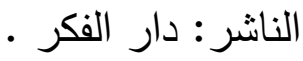

• rا. غاية الوصول في شرح لب الأصول لزكريا الأنصاري ، الناشر : دار

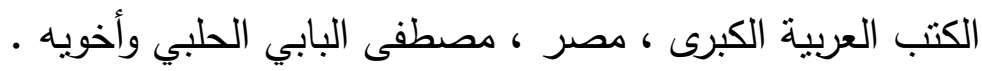

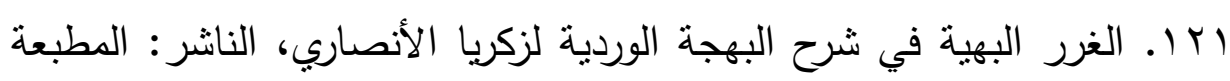

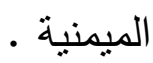

r r ا. . غمز عيون البصائر للحموي ، طبعة دار الكتب العلمية بيروت .

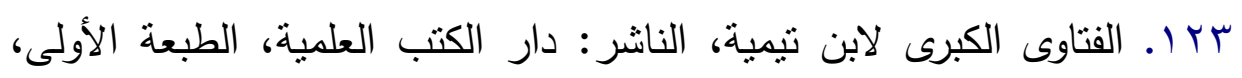

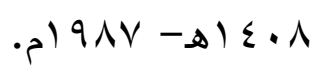

ع أ. فتح الباري شرح صحيح البخاري لابن حجر ، طبعة دار المعرفة ، بيروت

0ror فتح الباري شرح صحيح البخاري لابن رجب، تحقيق :مجموعة من

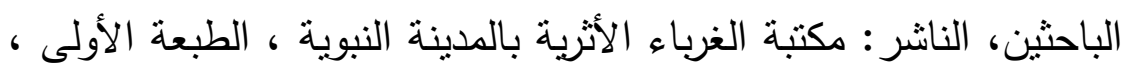

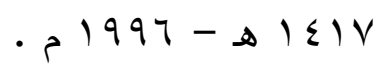

\ب ا. فتح باب العناية بشرح النقاية لملا علي القاري تحقيق محمد وهيثم نزار

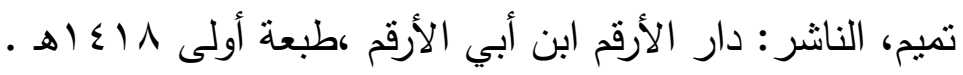

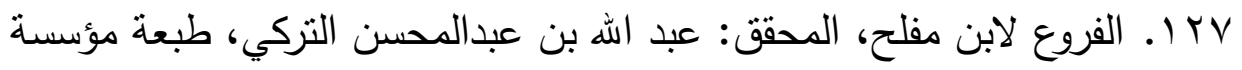

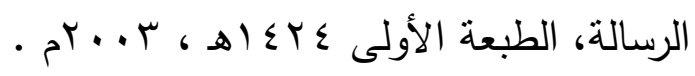

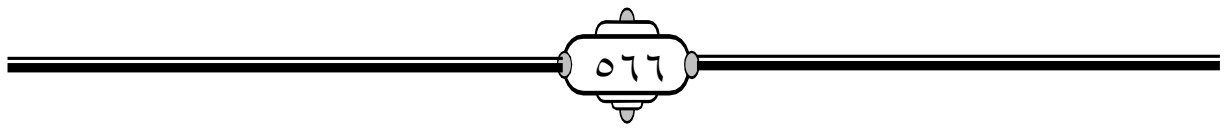




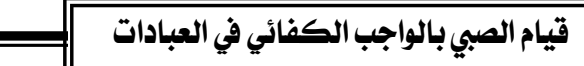

1Y ا. فواتح الرحموت بشرح مسلم الثبوت لابن نظام الدين الأنصاري، الناشر:

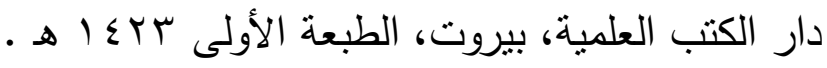

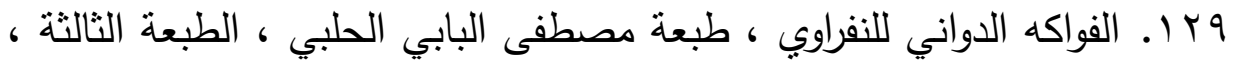
. ه TVE

•rrا. فيض القدير شرح الجامع الصغير للمناوي ، دار الكتب العلمية بيروت • لبنان

ابسا. القاموس الدحيط للفيروزابادي وتاج العروس للزبيدي ، الناشر: دار الهـاية .

بrا. قواعد الأحكام في مصالح الأنام للعز بن عبد السلام، تحقيق: طه

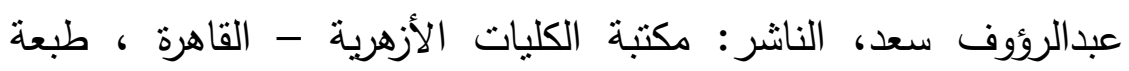

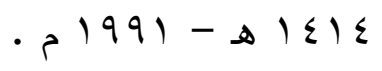

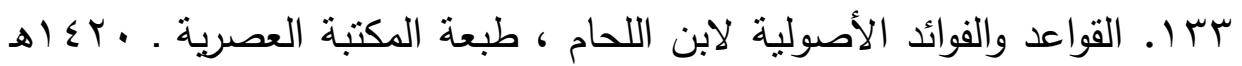

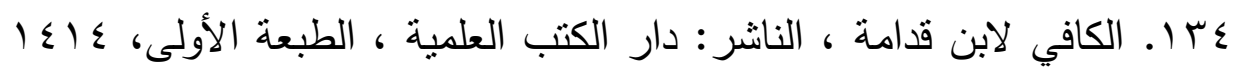

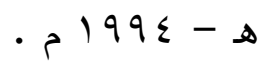

هـا . كثاف القناع للبهوتي، طبعة وزارة العدل السعودية ، طبعة أولى ،

$$
\text { . }
$$

جrا ا. كثف الأسرار شرح أصول البزدوي لعبد العزيز البخاري ، النانر: دار

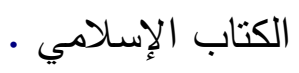

VTr I. كفاية الأخيار في حل غاية الاختصار للحصني ، المحقق: علي عبد

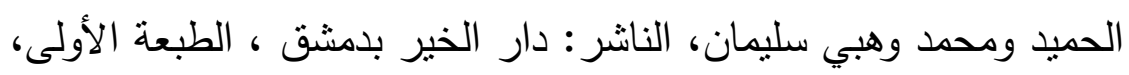

$$
\text { . } 199 \varepsilon
$$

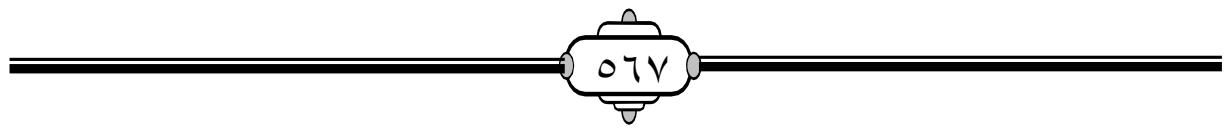




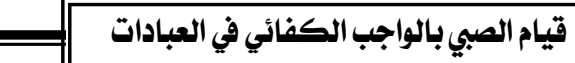

^r ا. كفاية الطالب الرباني لرسالة ابن أبي زيد القيرواني، المحقق: يوسف الثيخ

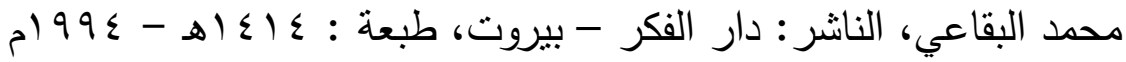

9 ا ا. كفاية النبيه شرح التتبيه لابن الرفعة ، المحقق: مجدي محمد سرور باسلوم

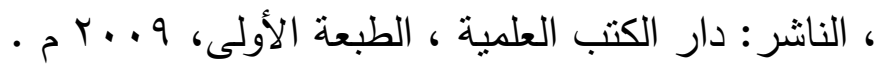

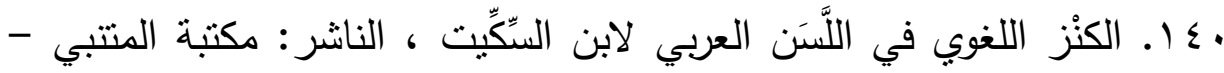

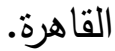

اء ا. لسان العرب لجمال الدين بن منظور ، طبعة دار صادر ، بيروت ،

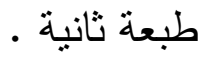

ץ؟ ا. لوامع الدرر في هنك أستار الدختصر للشنقيطي ، تصحيح وتحقيق: دار

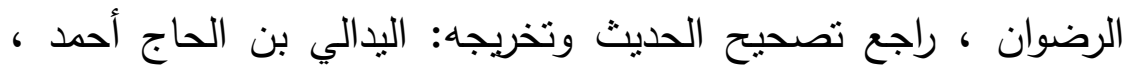

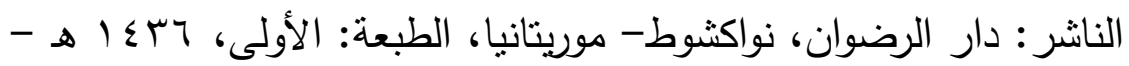
$\cdot{ }^{3} r \cdot 10$ بـ اــ المبدع شرح المقنع لبرهان الدين إبراهيم بن مفلح ، الناثشر : دار الكتب

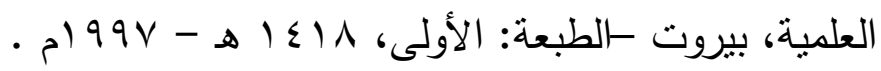

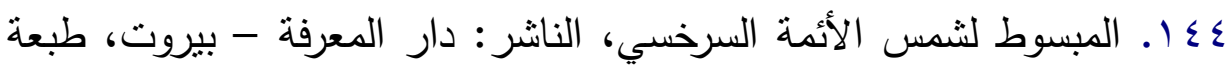

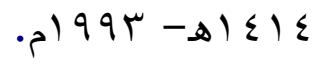

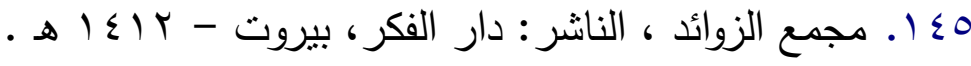
بـ ا. المجموع شرح المهذب للنووي ، الناشر : دار الفكر .

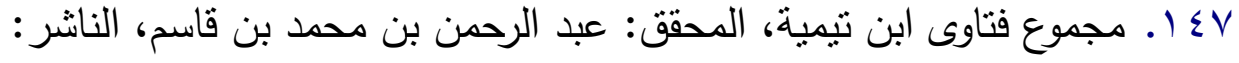

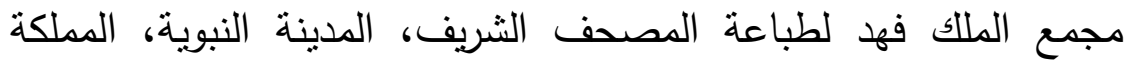

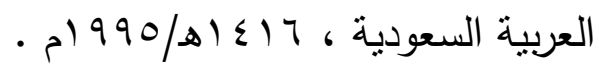

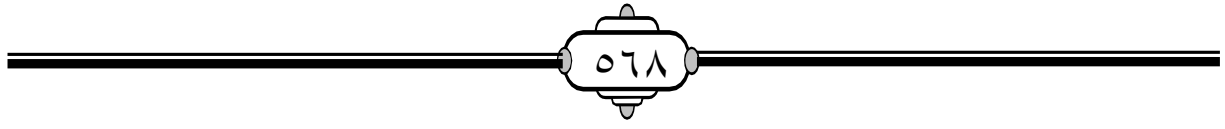




\section{قبيام الصبي بالواجب الكفائي في العباداته}

1ـ ا. المحرر في الفقه على مذهب الإمام أحمد بن حنبل، لمجد الدين أبي

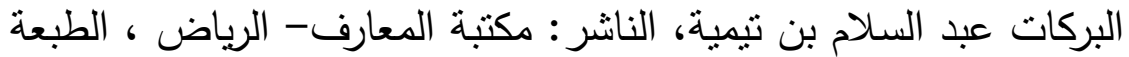

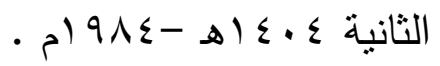

9؛ ا. المحصول للرازي، دراسة وتحقيق: الدكتور طه جابر فياض العلواني،

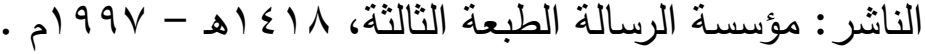
• 10 . المحلى بالآثار لابن حزم ، الناشر : دار الفكر - بيروت .

101 المحيط البرهاني في الفقه النعماني، الدحقق: عبد الكريم سامي الجندي،

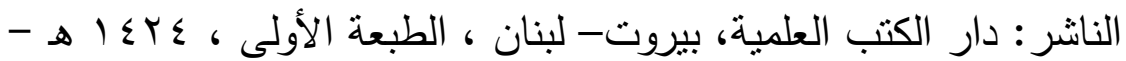

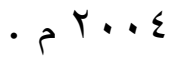

10 ا. المخصص لابن سيده، الناثر: دار إحباء التراث العربي - بيروت،

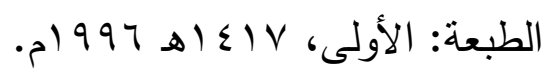

به اـ مرعاة المفاتيح شرح مشكاة المصابيح للمباركفوري ، الناشر إدارة البحوث العلمية والدعوة والإفتاء - الجامعة السلفية - بنارس الهند الطبعة الثالثة -

$$
\text { - } 191 \varepsilon-1 \leq 0
$$

ـ0 اـ مرقاة المفاتيح شرح مشكاة المصابيح للملا على القاري ،الناشر : دار

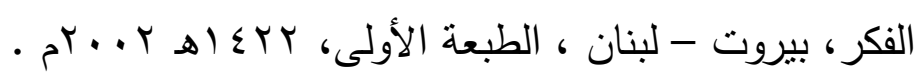

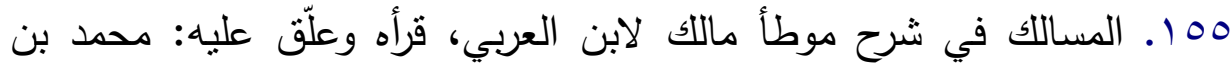

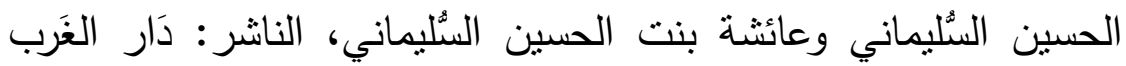

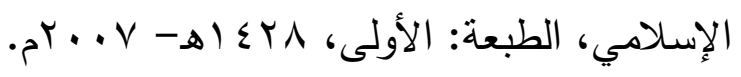

104. المسائل الفقهية من كتاب الروايتين والوجهين للقاضي أبي يعلى الفراء، المحقق: د.عبد الكريم بن محمد اللاحم، الناشر : مكتبة المعارف، الرياض الثين

$$
\text { ، الطبعة الأولى ، .ـ أهـ - } 910 \text { ام . }
$$

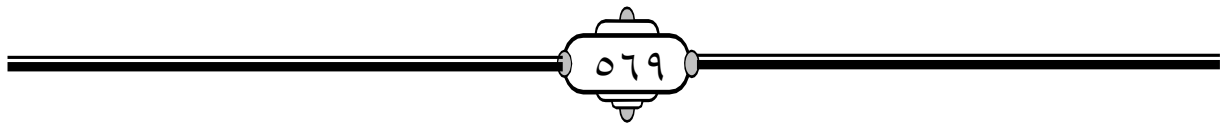




\section{قيام الصبي بالواجب الكفائي في العباداته}

10V V. المستدرك للحاكم، تحقيق: مصطفى عبد القادر عطا ، الناشر : دار الكتب

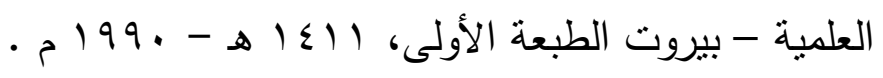

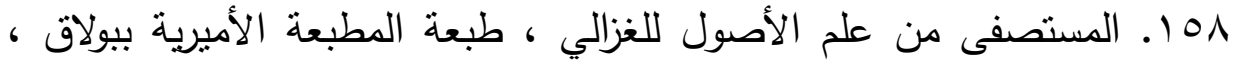

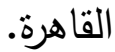

109 ـ مسند أبي يعلى، المحقق: حسين سليم أسد، الناشر: دار المأمون للتراث-

$$
\text { ـ } 17 .
$$

آ إ. المسودة لآل تيمية، المحقق: محمد محيي الدين عبد الحميد ، النانشر:

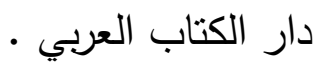

بآ ا. المصباح المنير في غريب الثرح الكبير للفيومي ، الناشر : المكتبة العلمية

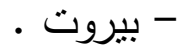

بآ ا. مصنف ابن أبي شيبة، المحقق: كمال يوسف الحوت، الناشر : مكتبة

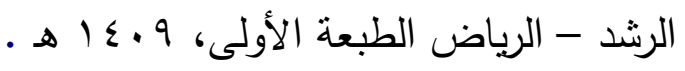

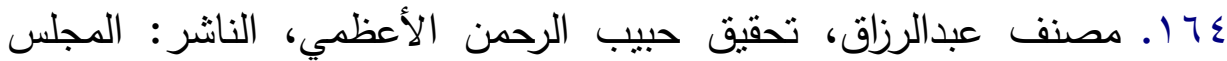
العلمي بالهند، المكتب الإسلامي بييروت، طبعة ثانية ب +ـ أهـ.

17 ا. مطالب أولي النهى في شرح غاية المنتهى للرحيباني ،الناثر المكتب

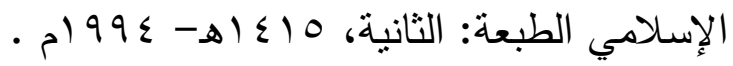

174. المطلع على أبواب المقنع للبعلي ، طبعة المكتب الإسلامي ، بيروت ، الإنهي

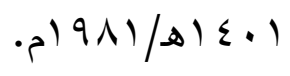

VT7 اـ المعجم الأوسط للطبراني، المحقق: طارق بن عوض الله بن محمد ، عبد

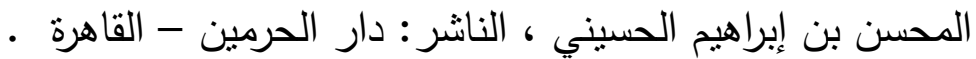

17 ا. المعجم الكبير للطبراني، المحقق: حمدي بن عبد المجيد السلفي ، دار النشر : مكتبة ابن تيمية - القاهرة، الطبعة: الثانية .

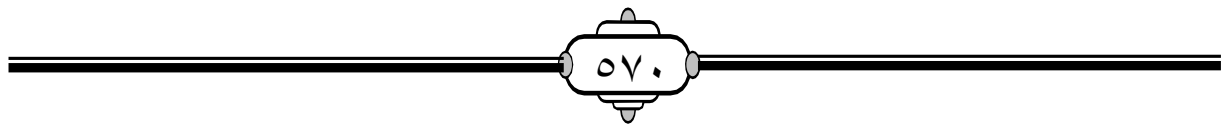




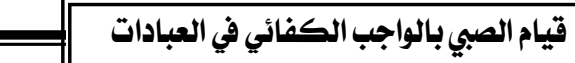

179. معجم مقاييس اللغة لابن فارس ، المحقق: عبد السلام محمد هارون ،

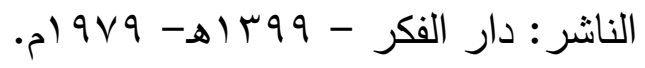

• V. V. المعونة على مذهب عالم المدينة للقاضي عبد الوهاب، المحقق: حميش عبد الحقّ ، الناشر: المكتبة التجارية، مصطفى أحمد الباز - مكة البه

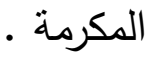

VI V المعيار المعرب للونشريسي، تحقيق جماعة من الفقهاء، بإنشراف الدكتور

محمد حجي، نشر وزارة الأوقاف والثؤون الإسلامية للملكة المغربية -

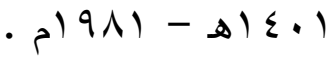

، IVT

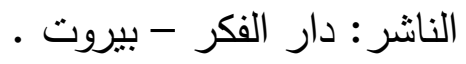

LVT ا. المغني لابن قدامة، تحقيق الدكتور عبداله بن عبدالمحسن التركي الدكتور عبد الفتاح محمد الحلو طبعة دار عالم الكتب ـ الرياض ـ الطبعة

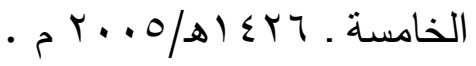

V V ا. المقدمات المهدات لابن رشد ( الجد ) ، ط مطبعة السعادة بمصر طبعة

$$
\text { أولى المقلى }
$$

lVo. المقدمات الممهدات لابن رشد الجد ، تحقيق: الدكتور محمد حجي ،

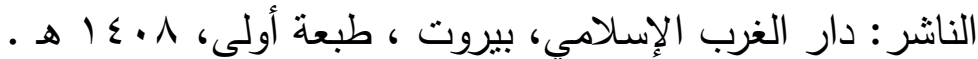
TVI ا. المتع في شرح المقنع لابن منجا، دراسة وتحقيق: عبد الملك بن عبد اله اله

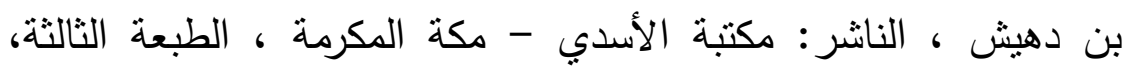

$$
\text { . }
$$

، IVV

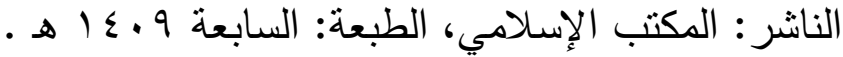

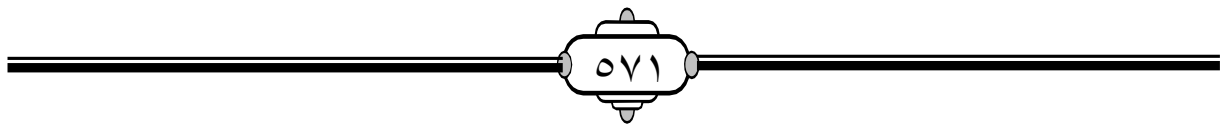




\section{قبيام الصبي بالواجب الكفائي في العباداته}

lVA للارجراجي، تحقيق: أبي الفضل الدّميَاطي - أحمد بن عليّ ، الناشر : دار

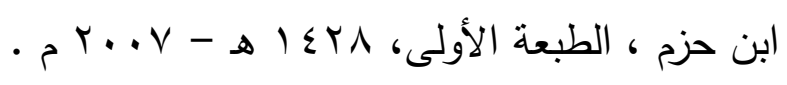

1V9. المنتقى شرح الموطأ للباجي، الناشر: دار الكتاب الإسلامي ، القاهرة الطبعة الثانية ، مصورة عن طبعة مطبعة السعادة - بجوار محافظة

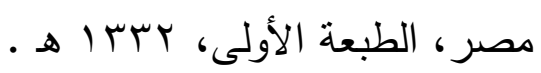

•11. المنثور في القواعد للزركثي، الناشر: وزارة الأوقاف الكويتية، الطبعة

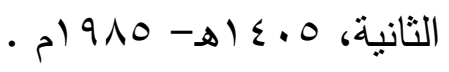

اN11. منهاج الوصول إلى علم الوصول للبيضاوي وشرح الإبهاج لتقي الدين

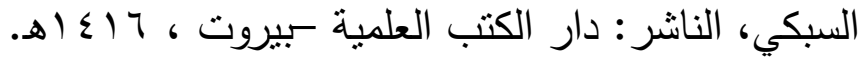

rN1. الموافقات للشاطبي، المحقق: أبو عبيدة مشهور بن حسن آل سلمان،

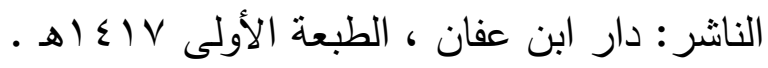

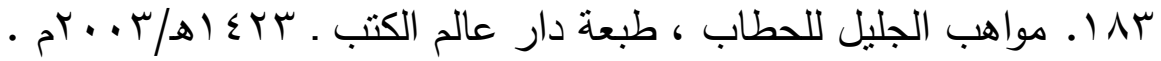

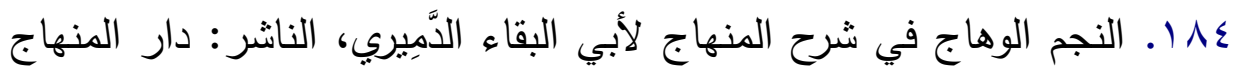

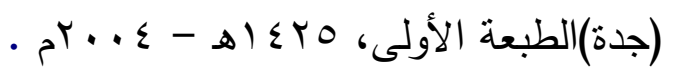

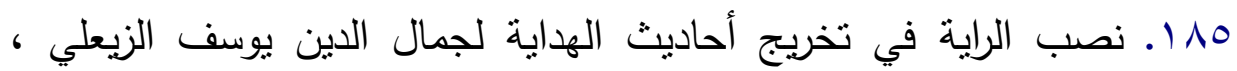
المحقق: محمد عوامة ، الناشر : مؤسسة الريان للطباعة والنشر - بيروت

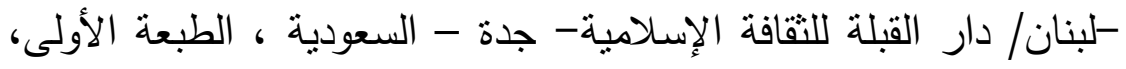

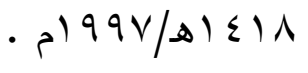

1111. نفائس الأصول شرح المحصول للقرافي ، طبعة المكتبة العصرية ، لبنان •

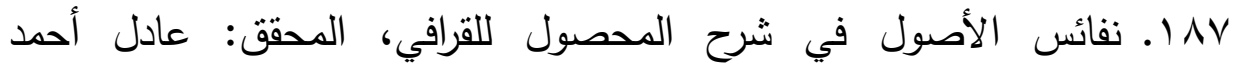
عبدالموجود، علي محمد معوض، الناشر : مكتبة نزار مصطفى الباز،

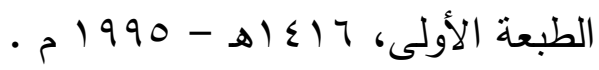

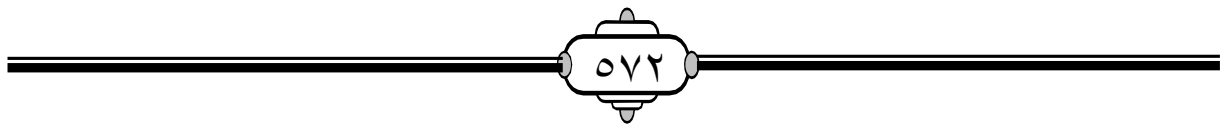




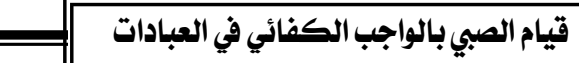

111، نهاية الزين في إرشاد المبتدئين لهحمد بن عمر نووي الجاوي، الناشر : دار

$$
\text { الفكر - بيروت، الطبعة الأولى . }
$$

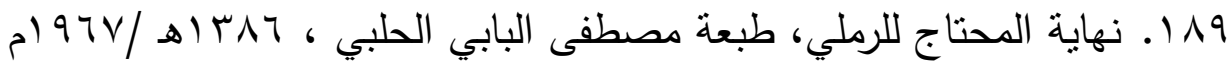

•9 1. نهاية الدطلب للجويني، تحقيق د/ عبد العظيم محمود الدّيب، النانر : دار

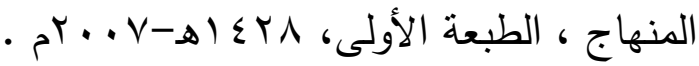

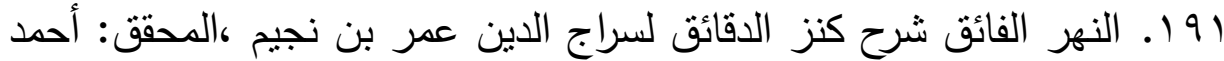

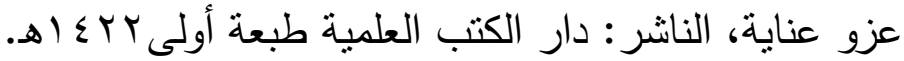

ب9 اـ النوادر والزيادات لابن أبي زيد القيرواني تحقيق مجموعة من الباحثين ،

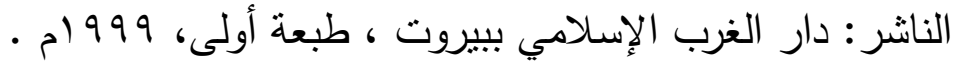
ب9 1. نيل الأوطار شرح منتقى الأخبار للشوكاني، تحقيق: عصام الدين

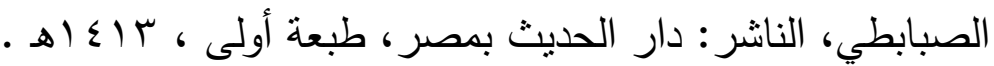
§ 1 ا. نيل المآرب بشرح دليل الطالب ، المحقق: الدكتور محمد سُليمان عبد الله

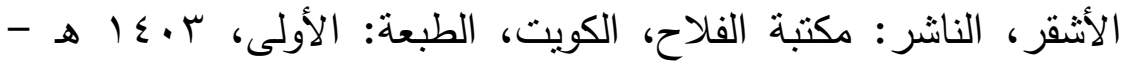

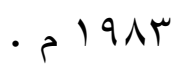

190 ـ هداية السالك إلى المذاهب الأربعة في المناسك لعز الدين بن جماعة،

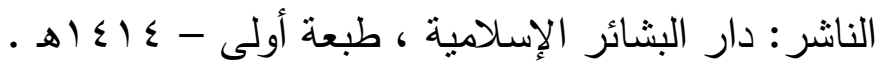

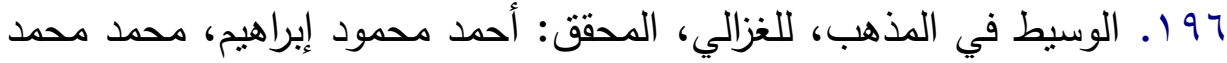

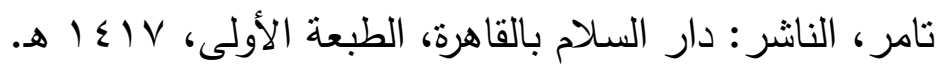

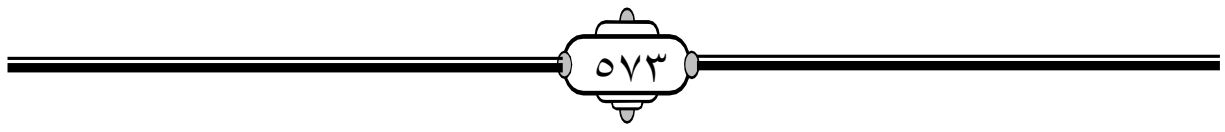


